UNIVERSIDADE DE SÃO PAULO

ESCOLA DE ENGENHARIA DE SÃO CARLOS

INSTITUTO DE FÍSICA DE SÃO CARLOS

INSTITUTO DE QUÍMICA DE SÃO CARLOS

\title{
INCIDÊNCIAS PATOLÓGICAS NO SUBSISTEMA ESTRUTURA DE EDIFÍCIOS HABITACIONAIS NA REGIÃO DE SÃO CARLOS/SP
}

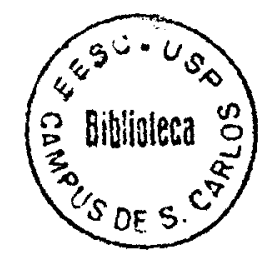

Eng. CLLENE DE CASSIA GARCIA

Dissertação apresentada à área interunidades em Ciência e Engenharia de Materiais, da Universidade de São Paulo, como parte dos requisitos para obtenção do título de Mestre em Ciência e Engenharia de Materiais.

ORIENTADOR: Prof. Dr. JEFFERSON B. L. LIBÓRIO

São Carlos

1999 


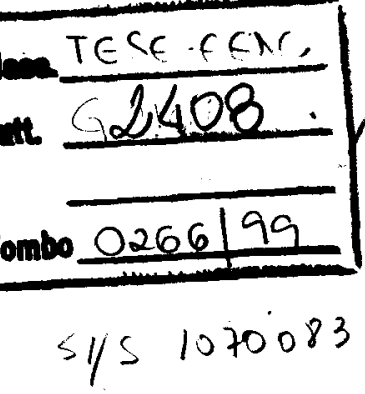

Ficha catalografica preparada pela Seçáo de Tratamento da Informaçăo do Serviço de Blblloteca - EESC/USP

\begin{tabular}{|c|c|}
\hline \multirow[t]{3}{*}{$\mathrm{G} 216 \mathrm{i}$} & $\begin{array}{l}\text { Garcia, Cilene de Cassia } \\
\text { Incidencias patológicas no subsistema estrutura } \\
\text { de edificios habitacionais na região de sao Carlos-sp / } \\
\text { Cilene de Cassia Garcia. -- São Carlos, } 1999 .\end{array}$ \\
\hline & $\begin{array}{l}\text { Dissertação (Mestrado) -- Escola de Engenharia de São } \\
\text { Carlos/Instituto de Fisica de São Carlos/Instituto de } \\
\text { Química de São Carlos-Universidade de São Paulo, 1999. } \\
\text { Area Interunidades: Ciência e Engenharia de } \\
\text { Materiais. } \\
\text { Orientador: Prof. Dr. Jefferson B. L. Libório. }\end{array}$ \\
\hline & $\begin{array}{l}\text { 1. Patologia. 2. Concreto armado. 3. Durabilidade. } \\
\text { 4. Deterioração. I. Título. }\end{array}$ \\
\hline
\end{tabular}




\section{Ciência e Engenharia de Materiais}

\section{UNIVERSIDADE DE SÃO PAULO}

Escola de Engenharia de São Carlos

CAIXA POSTAL - 369

Instituto de Física de São Carlos

CEP 13560-970 - São Carlos/SP - Brasil

Instituto de Química de São Carlos

MEMBROS DA COMISSÃO JULGADORA DA DISSERTAÇÃO DE MESTRADO DE CILENE DE CÁSSIA GARCIA, APRESENTADA A ÁREA INTERUNIDADES EM CIÊNCIA E ENGENHARIA DE MATERIAIS, DA EESC-IFSC-IQSC, UNIVERSIDADE DE SÃO PAULO, EM 18/3/1999.

\section{COMISSÃO JULGADORA:}

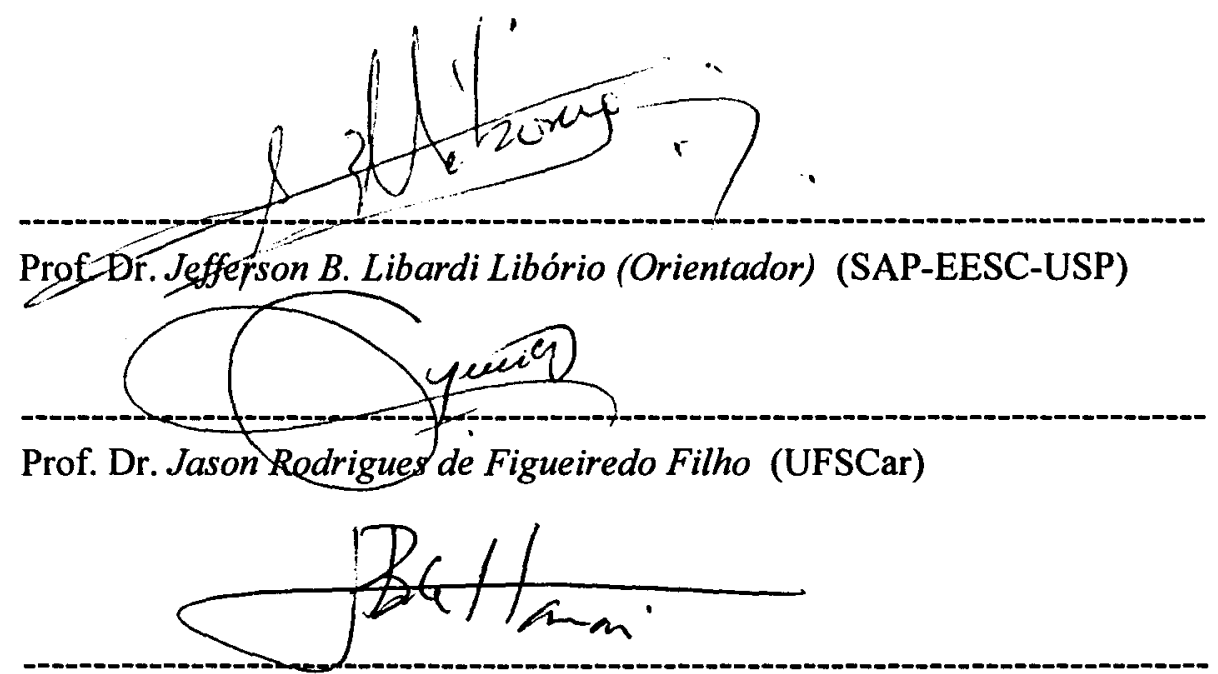

Prof. Dr. João Bento de Hanai (SET-EESC-USP) 
Aos meus pais,

pelo privilégio de tê-los

como meus mestres 


\section{AGRADECIMENTOS}

Ao Prof. Dr. Jefferson B. L. Libório pela orientação e toda colaboração fornecida durante a elaboração deste trabalho.

Ao Departamento de Arquitetura e Urbanismo por toda colaboração e suporte técnico concedidos.

À Coordenadoria de Aperfeiçoamento de Pessoal de Nível Superior CAPES, pela bolsa de estudos concedida.

Aos colegas de profissão, eng. ${ }^{\text {os }}$ Roberto Oki, Afonso e Francisco (Kiko), Manu, Gustavo Barreiro, Luís Fernando Martinez, José Armando Perissoto e Sr. Severino (mestre de obras) que colaboraram de forma imprescindível na elaboração desse trabalho.

Aos prof. ${ }^{\text {es }}$ José Samuel Giongo e Osny Pelegrino Ferreira pela colaboração e amizade.

A todos colegas do Laboratório de Construção Civil (LCC).

Aos técnicos e colegas Paulo Ceneviva e Osvaldo de Andrade e Marcelo (Secretaria) pela atenção, boa vontade e companheirismo.

Aos "meninos da AVR" e, em especial, Bel e Valtinho por toda força e companheirismo.

A família Dawa, extensão da minha, pelo apoio e respeito.

Às amigas Carol e Andréa, por todos os anos que estamos juntas, desde o princípio dos nossos tempos nessa cidade, e finalmente, as amigas e irmãs Giani Pfister, Rosangela Ballini e Laila Dawa, que, mesmo distantes, sempre estiveram do meu lado me acompanhando e apoiando. 


\section{SUMÁRIO}

1 INTRODUÇÃO

2 DURABILIDADE DAS ESTRUTURAS DE CONCRETO 11

2.1 - DEFINIÇÕES E CONCEITOS DE DURABILIDADE 11

2.2 - VIDA ÚTIL 13

2.3 - MANUTENÇÃO DAS CONSTRUÇÕES 16

2.4 - FATORES QUE INFLUENCIAM NA DURABILIDADE DO CONCRETO 19

2.4.1 - POROSIDADE E PERMEABILIDADE 19

2.4.1.1 - Porosidade $\quad 19$

2.4.1.2. - Permeabilidade $\quad 20$

2.4.1.2.a - Permeabilidade da pasta 21

2.4.1.2.b - Permeabilidade aos gases $\quad 22$

2.4.1.2.c- Permeabilidade do agregado $\quad 23$

2.4.1.2.d-Permeabilidade dos concretos $\quad 24$

2.4.2 - ADSORÇÃO 27

2.4.3 - ABSORÇÃO 27

2.5 CLASSIFICAÇÃO DAS CAUSAS DE DETERIORAÇÃO DO CONCRETO 28

2.5.1 - DETERIORAÇÃO DO CONCRETO POR AÇÕES FÍSICAS 30

2.5.1.1 - Deterioração devido ao desgaste superficial 30

2.5.1.2 - Deterioração devida à fissuração 31

2.5.2 - DETERIORAÇÃO DO CONCRETO POR REAÇõES 
2.5.2.c.1 Ataque por sulfatos 33

2.5.2.c.2 Reação álcalis-agregado 34

2.5.2.c.3 Hidratação do $\mathrm{MgO}$ e CaO cristalinos 35

2.5.2.c.4 Corrosão da armadura do concreto 35

2.6 - PRINCIPAIS MECANISMOS DE DETERIORAÇÃO E ENVELHECIMENTO DAS ESTRUTURAS DE CONCRETO 38

2.6.1 - RETENÇÃO DE FULIGEM E FUNGOS

2.7 - A INFLUÊNCIA DO MEIO AMBIENTE NA DURABILIDADE E PRINCIPAIS MEIOS AGRESSIVOS NO CONCRETO

2.8 - CLASSIFICAÇÃO DA AGRESSIVIDADE DO MEIO AMBIENTE

2.9 - CLASSIFICAÇÃO DOS CONCRETOS

3 PATOLOGIA DAS ESTRUTURAS DE CONCRETO ARMADO

3.1 - A IMPORTÂNCIA DA PATOLOGIA NAS ESTRUTURAS DE CONCRETO ARMADO

3.2 - A IMPORTÂNCIA DO PROJETO E SUAS FASES

3.3 - ATIVIDADES DO CONSTRUTOR

3.4-CONSIDERAÇÕES SOBRE OS MATERIAIS PARA SE EVITAR PATOLOGIAS

3.4.1 - CIMENTO

3.4.2 - AGREGADOS

3.4.3 - ÁGUA

3.4.4-ADITIVOS

3.4.5.- ARMADURAS 
3.5 - FATORES QUE DELIMITAM AS PATOLOGIAS NAS ESTRUTURAS DE CONCRETO ARMADO

3.6 - POSSÍVEIS DEFEITOS DE PROJETO ADVINDOS DA FALTA

DE CRITÉRIOS E DETALHAMENTOS

3.7 - DEFEITOS DE EXECUÇÃO E FORMAS DE PREVENÇÃO 72

3.8 - SINTOMATOLOGIA 76

3.8.1-FISSURAS

3.8.1.1 - Fissuração no estado plástico $\quad 78$

3.8.1.2 - Fissuração no estado endurecido $\quad 80$

3.8.1.2.a - Fissuras por movimentações térmicas $\quad 80$

3.8.1.2.b - Fissuras por movimentações higroscópicas $\quad 81$

$\begin{array}{lc}\text { 3.8.1.2.c - Fissuras pela atuação de sobrecargas } & 81\end{array}$

3.8.1.2.d - Fissuras por deformabilidade excessiva das estruturas de concreto armado

3.8.1.2.e - Fissuras por recalques de fundação $\quad 84$

3.8.1.2.f-Fissuras por retração de produtos a base de cimento 85

3.8.1.2.g - Fissuras por concentração de esforços $\quad 86$

3.8.2-DESAGREGAÇÃO

$\begin{array}{ll}\text { 3.8.3 -EFEITO PAREDE } & 87\end{array}$

3.8.4-DISGREGAÇÃO $\quad 88$

3.8.5 - CORROSÃO DA ARMADURA $\quad 89$

3.8.6 - NINHOS DE CONCRETAGEM(BICHEIRAS) 90

3.8.7-EFLORÊSCENCIAS 91

3.8.8 - SEGREGAÇÃO 92

3.8.9- CARBONATAÇÃO 92

3.8.10- LIXIVIAÇÃO 93

3.9 - O PANORAMA PATOLÓGICO NO BRASIL ENO MUNDO 94

4 METODOLOGIA ADOTADA NA PRESENTE PESQUISA

5 RESULTADOS

5.1 - OBSERVAÇÕES EM CONSTRUÇÕES DO SUBSISTEMA

ESTRUTURA 108

5.2 -EDIFÍCIO RESIDENCIAL “A” 112 
5.3-EDIFICIO RESIDENCIAL “B” 116

5.4-EDIFICIO RESIDENCIAL “C”

5.5-EDIFICIO RESIDENCIAL “D” 122

5.6-EDIFÍCIO RESIDENCIAL “E” 125

5.7-EDIFÍCIO RESIDENCIAL “F” 128

5.8-EDIFÍCIO RESIDENCIAL “ G” 131

5.9-EDIFICIO RESIDENCIAL “ $\mathrm{H}$ ” 134

5.10-EDIFICIO RESIDENCIAL “I” 138

5.11 - EDIFICIO RESIDENCIAL “" "

5.12 - EDIFÍCIO RESIDENCIAL “L”

6 DISCUSSÃO

6.1 - LAJE 149

6.2-VIGA 156

6.3-PILAR 163

6.4 - PAREDE 171

7 CONCLUSÕES E PROPOSTAS FUTURAS 176

8 REFERÊNCIAS BIBLIOGRÁFICAS 178

8.1 BIBLIOGRAFIA COMPLEMENTAR 183

ANEXO A

ANEXO B 191

ANEXO C 200

ANEXO D 209

ANEXOE $\quad 218$

ANEXOF $F$

ANEXO G 227

ANEXO H 234

ANEXO I 247

ANEXO J 260

ANEXO L 269

GLOSSÁRIO 


\section{LISTA DE FIGURAS}

FIGURA 01 - Origem dos problemas patológicos na Grã-Bretanha.

FIGURA 02 - Patologias observadas e suas quantificações na Grã-

Bretanha.

FIGURA 03 - Incidência dos problemas pela origem a nível nacional

FIGURA 04 - Vida útil em função da distribuição estatística normal de componentes.

FIGURA 05 - Conceituação de vida útil das estruturas de concreto tomandose por referência o fenômeno de corrosão de armaduras.

FIGURA 06 - Relação entre desempenho, manutenção e vida útil.

FIGURA 07 - Variação dos custos de manutenção e reparo ao longo do tempo.

FIGURA 08 - Esquema ilustrativo sobre porosidade e permeabilidade.

FIGURA 09 - Influência da relação água/cimento na permeabilidade de pastas de cimento Portland altamente hidratadas (93\%).

FIGURA 10 - Classificação das causas de deterioração do concreto.

FIGURA 11 - A influência da temperatura e do tipo de agregado sobre a resistência a compressão do concreto.

FIGURA 12 - Célula de corrosão.

FIGURA 13 - Detalhes da armadura de traspasse em projeto.

FIGURA 14 - Detalhes de emendas das barras.

FIGURA 15 - Fissura de sedimentação pelo impedimento da armadura.

FIGURA 16 - Fissura de sedimentação pelo impedimento do agregado. 
FIGURA 18 - Fissura por movimentos laterais da fồrma. 79

FIGURA 19 - Fissuras típicas de recalques diferenciais. 85

FIGURA 20 - Foto registrando efeito parede em laje maciça de concreto armado.

FIGURA 21 - Foto de disgregação ocasionada por corrosão da armadura no pé de pilar.

FIGURA 22 - Foto registrando fissuras causadas por expansão e corrosão da armadura no pé do pilar.

FIGURA 23 - Foto de eflorescências em laje maciça seguidas de lixiviação e carbonatação.

FIGURA 24 - Foto registrando segregações do concreto por toda extensão do pilar.

FIGURA 25 - Avaliação das incidências segundo sua origem. 95

FIGURA 26 - Quantificação das incidências mais observadas. 96

FIGURA 27 - Origem dos problemas patológicos na cidade de São Paulo.

FIGURA 28 - Distribuição dos tipos de problema observados na cidade de São Paulo.

FIGURA 29 - Distribuição dos tipos de problema observados na região Nordeste do país.

FIGURA 30 - Distribuição dos tipos de problema observados na região Amazônica do país. 98

FIGURA 31 - Faces do pilar deformadas por reutilização excessiva das 109 fôrmas.

FIGURA 32 - Desaprumo das paredes estruturais ao longo dos 109 pavimentos.

FIGURA 33 - Falta de cobrimento no fundo de viga.

FIGURA 34 - Falta de alinhamento horizontal do fundo da viga.

FIGURA 35 - Falta de vibração devido à interferência do subsistema de instalações elétricas.

FIGURA 36 - Reparo com argamassa de cimento e areia no pé de pilar devido o excesso de segregações após à concretagem.

FIGURA 37 - Classificação dos tipos de incidências observados em 
relação ao número de ocorrências.

FIGURA 38 - Sujeira proveniente de flocos de EPS impedindo passagem do concreto segregação

FIGURA 39 - Falta de alinhamento lateral da parede devido deformação das fôrmas.

FIGURA 40 - Laterais fora de alinhamento devido excesso de pressão nos tensores das fôrmas. 
LISTA DE TABELAS

TABELA 01 - Comparação entre permeabilidade de agregados (rochas) e pasta de cimento Portland.

TABELA 02 - Mecanismos de degradação das superficies de concreto.

TABELA 03 - Classes de agressividade ambiental.

TABELA 04 - Classes de agressividade do ambiente em função das condições de exposição.

TABELA 05 - Classificação da agressividade ambiental visando a durabilidade do concreto.

TABELA 06 - Classificação da resistência dos concretos frente ao risco de corrosão de armaduras.

TABELA 07 - Classificação da resistência dos concretos frente ao risco de deterioração por lixiviação ou por formação de compostos expansivos.

TABELA 08 - Correspondência entre agressividade do ambiente e durabilidade do concreto.

TABELA 09 - Necessidades dos Usuários: Transformação em Exigências.

TABELA 10 - Correspondência entre classe de agressividade e cobrimento nominal.

TABELA 11 - Fissuras não produzidas por cargas : causas, características e precauções.

TABELA 12 - Origem das patologias em países europeus. 94

TABELA 13 - Quantificação das manifestações em países europeus. 95 
TABELA 14 - Tabela utilizada na pesquisa em campo para investigação do fck empregado.

TABELA 15 - Formulário de investigação "in loco".

TABELA 16-Número de observações e porcentagens de incidências

patológicas parciais para cada elemento estrutural e integral do edificio " $A$ ".

TABELA 17 - Número de observações e porcentagens de incidências

patológicas parciais para cada elemento estrutural e integral do edificio "B".

TABELA 18 - Número de observações e porcentagens de incidências patológicas parciais para cada elemento estrutural e integral do edificio " $\mathrm{C}$ ".

TABELA 19 - Número de observações e porcentagens de incidências patológicas parciais para cada elemento estrutural e integral do edificio "D".

TABELA 20 - Número de observações e porcentagens de incidências patológicas parciais para cada elemento estrutural e integral do edificio " $\mathrm{E}$ ".

TABELA 21 - Número de observações e porcentagens de incidências patológicas parciais para cada elemento estrutural e integral do edificio " $\mathrm{F}$ ".

TABELA 22 - Número de observações e porcentagens de incidências patológicas parciais para cada elemento estrutural e integral do edificio "G".

TABELA 23 - Número de observações e porcentagens de incidências patológicas parciais para cada elemento estrutural e integral do edificio ' $\mathrm{H}$ ".

TABELA 24 - Número de observações e porcentagens de incidências patológicas parciais para cada elemento estrutural e integral do edificio " $\mathrm{T}$ ".

TABELA 25 - Número de observações e porcentagens de incidências patológicas parciais para cada elemento estrutural e integral do 
edificio " $\mathrm{J}$ ".

TABELA 26 - Número de observações e porcentagens de incidências patológicas parciais para cada elemento estrutural e integral do edificio "L".

TABELA 27 - Total de ocorrências por elemento estrutural

TABELA 28 - Resumo das incidências observadas no elemento estrutural - laje em todos edifícios.

TABELA 29 - Resumo das incidências observadas no elemento estrutural - viga em todos edificios.

TABELA 30 - Resumo das incidências observadas no elemento estrutural - pilar em todos edifícios.

TABELA 31 - Resumo das incidências observadas no elemento estrutural - parede em todos edificios 


\section{RESUMO:}

GARCIA, C. C. (1999) - Incidências Patológicas no Subsistema Estrutura de Edificios Habitacionais na Região de São Carlos/SP. São Carlos, 1999. 272p. Dissertação (Mestrado) - EESC/ IFSC/ IQSC, Universidade de São Paulo.

O presente trabalho tem como objetivo quantificar estatisticamente a ocorrência de falhas geradas pelos erros de projeto e execução das construções. Para isso, elaborouse um checklist que se subdividiu em duas partes: a primeira contendo informações desde a concepção à geração de um edificio e a segunda para verificação da estrutura "in loco" em edifícios habitacionais em construção na cidade de São Carlos. Quantificou-se as incidências patológicas observadas por elemento estrutural e finalmente se traçou um panorama da atual realidade dos edificios sob o ponto de vista das patologias geradas pela falta de controle de qualidade nas construções.

Através dos dados obtidos pôde-se verificar a existência de várias patologias, destacando-se a segregação do concreto de pilares e paredes, cobrimento inadequado do concreto em vigas e problemas advindos da falta de estanqueidade de fôrmas em lajes.

Palavras Chave: Patologia, Concreto Armado, Durabilidade, Deterioração 


\begin{abstract}
:
GARCIA, C. C. (1999) - Pathological Incidences on Structure Subsystem of Housing Buildings in the region of São Carlos/SP. São Carlos, 1999. 272p. Dissertação (Mestrado) - EESC/ IFSC/ IQSC, Universidade de São Paulo.
\end{abstract}

The goal of this work is the quantify statistically the occurrance of failure generated by carelessness with the project and execution of the constructions. A check-list was proposed was subdivided in two parts: the first with information since the conception to generation of a building and the second by the verification of the building structure "in loco" in São Carlos town. It was quantified the pathological incidences observed by structural element and finally it was designed a panorama of the actual reality of the buildings under the view of the pathologies generated by the lack of control and quality in the constructions.

Through the obtained data it could be verified the existence of several patologies, highlighting the segregation of concrete in pillars and walls, inadequate covering of concrete in beams and problems from the lack of stanching of moulds in flagstone.

Keywords: Pathology, Reinforced Concrete, Deterioration, Durability 


\section{INTRODUÇÃo}

Hoje em dia é desejável que, ao se projetarem estruturas de concreto armado, as características de durabilidade dos materiais em questão sejam avaliadas com o mesmo cuidado com relação a outros parâmetros, tais como propriedades mecânicas e custo inicial.

Em primeiro lugar, há uma maior preocupação com as implicações sócioeconômicas da durabilidade. De modo crescente, os custos de reparo e substituições em estruturas devido a falhas nos materiais têm se tornado parte substancial do orçamento total das construções.

Por exemplo, em países industrialmente desenvolvidos estima-se que acima de $40 \%$ do total dos recursos da indústria da Construção Civil sejam aplicados em reparos e manutenção de estruturas já existentes, e menos de $60 \%$ em novas instalações.

O crescimento do custo de reposição de estruturas e a ênfase crescente no custo do ciclo de vida, em vez do custo inicial, estão forçando os engenheiros a tomarem consciência do conceito de durabilidade.

Os estudos das lesões ou enfermidades nas estruturas são fenômenos tão velhos como os próprios edifícios.

$\mathrm{Na}$ Mesopotâmia, há quatro mil anos, o Código de Hamurabi já assinalava cinco regras para prevenir defeitos nos edifícios, sendo pois o primeiro tratado conhecido sobre Patologia na Construção.

As cinco regras básicas a que se refere o citado Código, pelo drástico de seu conteúdo, devem ter tido, naquela época, uma grande repercussão na qualidade da construção. Essas regras eram: 
1- se um construtor faz uma casa para um homem e não a faz firme, e seu colapso causa a morte do dono da casa, o construtor deverá morrer;

2- se causa a morte do filho do dono da casa, o filho do construtor deverá morrer;

3- se causa a morte de um escravo do proprietário da casa, o construtor deverá dar ao proprietário um escravo de igual valor;

4- se a propriedade for destruída, ele deverá restaurar o que for danificado por sua própria conta;

5- se um construtor faz uma casa para um homem e não a faz de acordo com as especificações e uma parede desmorona, o construtor reconstruirá a parede por sua conta.

Esses tópicos tratavam da questão sob o aspecto da intimidação. Nos tempos atuais, embora inexistam esses princípios, em muitas vezes, diante de problemas advindos de desastres, os profissionais acabam passando por traumas emocionais que muitas vezes os penalizam de forma severa.

No Brasil, alguns conceitos específicos, relacionados com a qualidade das edificações, foram desenvolvidos: controle tecnológico de materiais, particularmente para uso estrutural; avaliação de desempenho e estudos de durabilidade dos materiais e componentes. Entretanto, pouca atenção tem sido dada à integração dessas metodologias e a enfoques mais amplos e sistêmicos da gestão da qualidade, utilizados nos demais setores industriais.

Diante da necessidade de sistematizar esses conhecimentos e com o objetivo de se criar um caminho para todo o campo da Engenharia, que tratasse de forma científica os problemas estruturais, procurou-se a analogia dos defeitos das edificações com as doenças na medicina.

A partir dessa idéia, consolida-se a utilização do termo "Patologia" para definir esse campo da engenharia.

Segundo HELENE (1986), "Patologia pode ser entendida como a parte da Engenharia que estuda os sintomas, os mecanismos, as causas e as origens dos defeitos das construções civis, ou seja, é o estudo das partes que compõem o diagnóstico do problema". 
A Patologia das Construções está intimamente ligada à qualidade e, mesmo com essa última tendo avançado muito em alguns países e continue progredindo cada vez mais, os casos patológicos não diminuíram na mesma proporção.

Diversos pesquisadores têm divulgado os instantes onde se originam os principais problemas patológicos. DIHR et al. apud HELENE (1992), analisaram a situação na Europa e puderam constatar a existência desses problemas em grande parte dos países europeus. A nível ilustrativo pode-se observar através das Figuras 01 e 02 respectivamente a origem e quais são as maiores patologias observadas com seus respectivos números para a Grã-Bretanha.

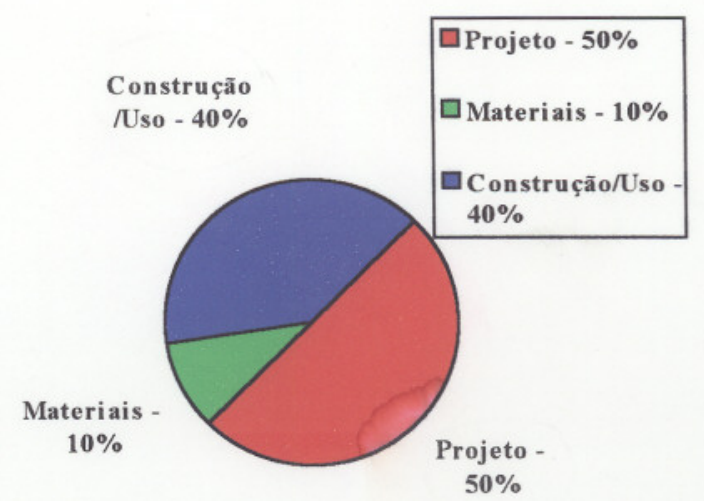

FIGURA 01-Origem dos problemas patológicos na Grã-Bretanha (HELENE,1992).

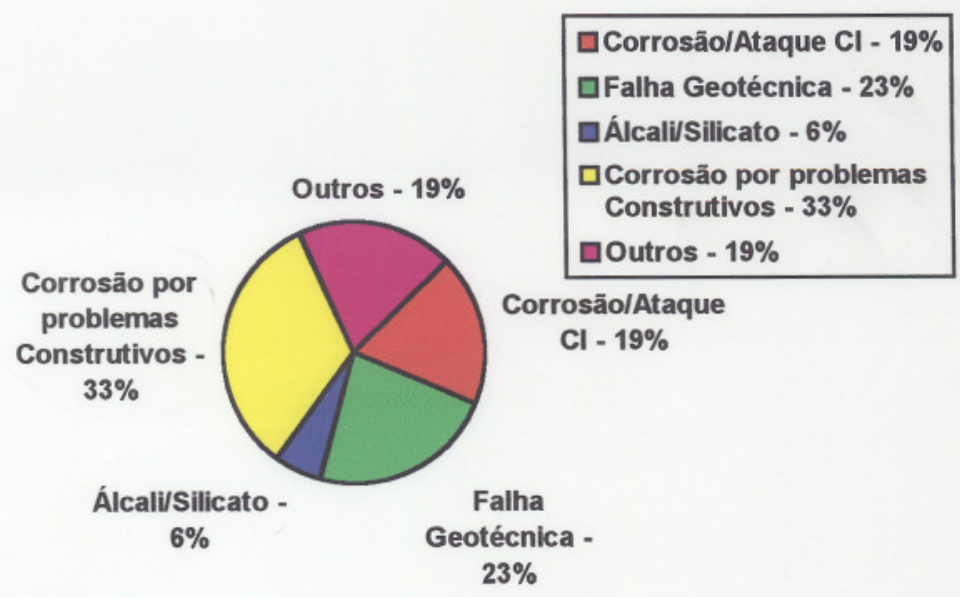

FIGURA 02 - Patologias observadas e suas quantificações na Grã-Bretanha (HELENE,1992). 
CARMONA FILHO, A. (1988) divulgou a situação existente no Brasil, que apresenta na Figura 03 a seguinte estatística:

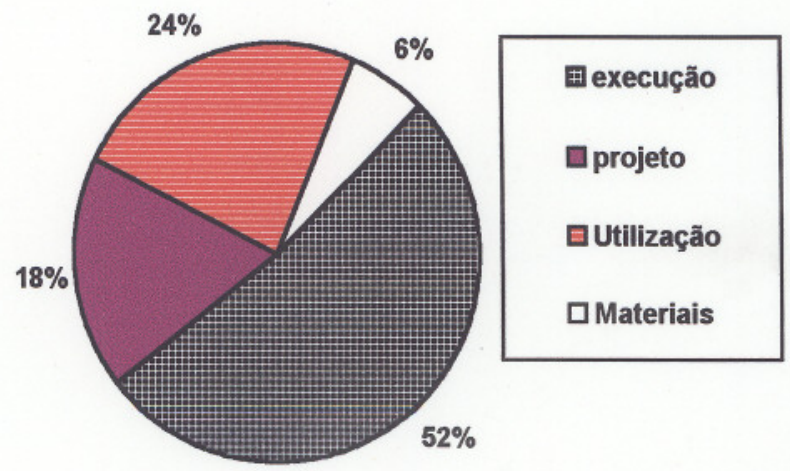

FIGURA 03 - Incidência dos problemas pela origem a nível nacional (CARMONA, 1988).

Como pôde ser observado pelas estatísticas acima, muitos autores designam que as patologias provêm de vários fatores sendo, que grande parte delas causam controvérsias ao se detectar em qual fase da edificação elas surgem. Alguns autores defendem que a maior parte das patologias surgem devido ao descaso na elaboração dos projetos sendo esses muitas vezes carentes de informações. Outros autores defendem que os problemas patológicos surgem exclusivamente na execução das edificações que são seguidas de vícios tanto por parte de execução em si quanto dos profissionais que as executam. Alguns já entram em um consenso de que um controle severo tanto na fase de projeto quanto na executiva reduziria bruscamente o surgimento das patologias.

Projetar uma estrutura de concreto não pode se ater simplesmente aos conceitos da Engenharia Civil, principalmente nos dias de hoje. Fatores como meio ambiente que em outros tempos era fator irrelevante, hoje pode ser informação crucial na implantação de uma construção. Afinal, chuva ácida, por exemplo, pertence a rotina de qualquer centro urbano.

A minimização dos custos de execução e manutenção é o fator que move qualquer orçamento de obra e além disso novos parâmetros como impacto ambiental, evolução tecnológica, otimização de processos construtivos, entre outros, são conceitos que no passado nada significava e hoje, essa desconsideração tem sido motivo de inviabilização de projetos. 
O fato é que o processo da Construção Civil pode ser esquematizado a partir de três fases características: concepção, execução e utilização. Cada uma dessas fases é realizada por profissionais da construção com atributos e responsabilidades específicas.

0 custo e o desempenho do produto final da edificação estão intimamente ligados à qualidade do projeto, e desde a primeira etapa do estudo preliminar já se deve tomar precauções de modo a evitar as origens das falhas na construção. Como origem das falhas pode-se detectar a incompatibilidade entre os vários projetos, as omissões específicas e a incompatibilidade do projeto com o meio no qual se situa a construção.

Como exemplos de falhas ocorridas na fase de projeto observam-se:

$\Rightarrow$ baixa qualidade dos materiais propostos;

$\Rightarrow$ especificação de materiais incompatíveis;

$\Rightarrow$ detalhamento insuficiente (omissão ou erro);

$\Rightarrow$ detalhe construtivo inexeqüível;

$\Rightarrow$ falta de clareza nas informações;

$\Rightarrow$ falta de padronização de representação;

$\Rightarrow$ erro de dimensionamento;

$\Rightarrow$ avaliação do meio ambiente e/ou micro clima.

No caso da fase da execução tem-se um fator agravante, pois apesar de na maioria das vezes sempre haver profissionais da área liderando uma construção encontra-se a absorção de uma mão-de-obra completamente desqualificada, a qual se caracteriza pela falta de treinamento, analfabetismo e, apesar de ser uma produção manufatureira que caracteriza uma grande absorção de mão-de-obra, há uma enorme rotatividade associada à descontinuidade do fluxo de obras.

Todos esses fatores levam à baixa produtividade da mão-de-obra, pois tem-se o uso intensivo de ferramentas manuais e apenas marginal de máquinas o que gera uma baixa qualidade do produto final.

Analisando mais a fundo os aspectos sociais dessa mão-de-obra, observa-se que: os salários não são condizentes com o dispêndio do trabalhador, a jornada de trabalho é excessiva, há uma enorme falta de segurança criando grande risco de acidentes e uma falta de motivação para o trabalho. 
Para se iniciar uma discussão sobre a melhoria da qualidade e, consequentemente, diminuir o número de incidências patológicas ocorridas, deve-se conter essa falta de qualificação dos operários, sendo necessário haver um controle da produção na construção. Este, por sua vez, é exercido por oficiais, encarregados e mestres ou contramestres que nada mais são que profissionais formados no canteiro.

Estes profissionais são os responsáveis por intermediar as relações engenheiros $\mathrm{X}$ operários pois conhecem a linguagem dos operários. Em contrapartida são também indivíduos resistentes às inovações, o que torna muitas vezes um engenheiro de obras incapaz de aplicar seus conhecimentos teóricos aos casos práticos reais.

Sendo assim, a qualidade e a produtividade de uma construção são influenciadas diretamente pela capacitação do mestre e do engenheiro.

Segundo levantamentos de campo, as principais patologias observadas (projeto ou execução) associam-se a:

- ausência de avaliação de agressividade do meio ambiente;

- efeito parede provocado pelas proximidade da fồma à armadura;

- cobrimentos da armadura insuficientes frente à agressividade do meio;

- deficiência de adensamento e cura;

- utilização de fôrmas incompatíveis com as hipóteses de projeto.

ROBERT STEPHENSON no seu discurso de posse na presidência no Instituto de Engenharia Civil da Grã-Bretanha (1856) já assinalava a importância da problemática: "...Tenho esperança de que todas casualidades e acidentes, que têm acorrido nos últimos anos, sejam notificados. Nada é tão instrutivo para jovens engenheiros como o estudo dos acidentes e dos meios empregados para o reparo das lesões. A descrição exata desses acidentes, com o entendimento correto dos mecanismos de ocorrência, é realmente mais valioso que a descrição dos trabalhos bem-sucedidos. Os engenheiros mais velhos retiram os mais úteis ensinamentos da observação destas casualidades, que podem ocorrer nas próprias obras ou nas obras de outros profissionais. Neste sentido é que proponho a catalogação destes acidentes nos arquivos desta Instituição..." 
Outros eventos destacaram a importância dos estudos sobre Patologia, conforme cronologia apresentada a seguir.

- CRISTOBAL RUSSO - "Lesões dos Edifícios" - 1915 - ..."os edifícios velhos e deteriorados podem ser comparados aos enfermos, sendo conveniente inspecionálos em toda a sua nudez, sem a necessidade de roupagens inúteis..."

- HENRY LOSSIER - 1926 - Usa correntemente o termo PATOLOGIA para delimitar 0 estudo dos danos nas estruturas de concreto armado -..."O estudo sistemático dos acidentes e suas causas faz parte da mesma forma que o estudo das construções normais"

- CAETANO CASTELI - 1951 - Autor do livro "Patologia do Concreto Armado"

- BRASIL - 1971 - Ocorrem dois acidentes de grandes proporções: Pavilhão de Exposições da Gameleira (Belo Horizonte/MG) - 04/02/1971 e Viaduto "Paulo de Frontin" no Rio de Janeiro em 20/11/1971.

- 1972 - CICLO DE PALESTRAS sob o título Patologia das Estruturas - presentes os Engs. Eládio Petrucci, Francisco de Assis Basílio, Luiz Santos Reis, Darcy Amora Pinto, Augusto Carlos de Vasconcelos.

- 1982 - Primeiros trabalhos divulgados e pesquisados no Brasil.

- 1985 - Pesquisas mais aprofundadas com elaboração de grupos de pesquisa.

- 1985 - A EESC-USP inicia uma série de pesquisas sobre os Estudos de Patologia das Construções - Nov. - Pesquisa CNPq.

- 1990 - Criação de disciplinas a nível de pós-graduação sobre o tema, na EESCUSP.

- 1990 - É editada a lei 8.078, de 11/09/1990, Código de Proteção e Defesa do Consumidor.

- 1993 - Início da Revisão da NB1 - ABNT.

- 1995 - CREA - Lançamento da Campanha de Defesa ao Consumidor - Área: Engenharia Civil.

- 1996 - Primeiro exame de Avaliação de Cursos para Engenharia Civil, Administração e Direito (Técnica X Administração X Legislação).

$\mathrm{Na}$ realidade, há uma grande dificuldade em catalogar a situação patológica corrente, pois os defeitos geralmente são escondidos, exceto as grandes fatalidades 
que se tornam impossíveis de serem camufladas. Acontece, freqüentemente, que se dá pouca importância a muitos dos defeitos ou lesões apresentados pelas estruturas que, por isso, não chegam a formar parte das estatísticas, já que o próprio construtor os corrige, cobre ou esconde (como é o caso das imperfeições que ocorrem durante a execução das concretagens ou, dos erros de projeto do arranjo das armaduras que dificultam essas realizações).

Defeitos mais ou menos importantes e espetaculares são os que, em geral, destacam-se em revistas ou livros especializados. Mas, os que não provocariam uma catástrofe imediata por serem enfermidades progressivas que terminarão arruinando a estrutura, não ocupam espaço nas revistas nem são alvo de publicidade. No entanto, o usuário do edifício ou construção é que terá que suportá-los.

No Brasil, a Construção Civil é um setor tradicional e com diversas particularidades, que apresenta defasagem de vários anos, em relação aos setores industriais mais dinâmicos, no que diz respeito ao gerenciamento da qualidade mesmo depois de criados quesitos específicos para ela.

Essa defasagem, no entanto, torna-se curiosa, pois o Brasil detêm não só um grande número de profissionais na área como também estudos e técnicas que colocam nosso país em lugar de destaque além de ser competitivo quando comparado a outros países.

O setor da construção em 1995 representou 13,5\% do Produto Interno Bruto. Desse número, a Indústria da Construção que representa os segmentos das habitações, edificações e construção pesada assegura $8 \%$ do PIB, representando algo em torno de R\$ 45 bilhões. A arrecadação de tributos federais realizada pela Indústria da Construção em 1996 corresponde à 4\%. Até 1995 o total de pessoas ocupadas na Construção Civil girou em torno de 4,3 milhões sendo que 1,2 milhões (5\%) foram ocupadas no setor de edificações e habitações

Essas estatísticas foram obtidas mediante um trabalho de consultoria realizado pela TREVISAN CONSULTORES (1997), a fim de diagnosticar a realidade do setor da Construção no país que tem pela frente o desafio de um déficit habitacional que atingiu até 1995 mais de 5 milhões de famílias. Há também a necessidade de adequação em programas de Qualidade Total para se obter certificados de qualidade que garantam um espaço no mercado. É o caso de algumas 
poucas construtoras do setor - Método Engenharia S.A (SP) e Construtora Lacerda Chaves (Ribeirão Preto) - que obtiveram o Certificado de Qualidade ISO - 9002 garantindo com isso a qualidade nas suas construções e consequentemente a redução de patologias.

O presente trabalho tem como finalidade contribuir e servir de instrumento para a melhoria das condições em que se encontram os edificios existentes na região de São Carlos.

Com esse fim, várias questões foram estabelecidas, sendo a primeira delas o surgimento de uma ferramenta de trabalho que permite verificar a qualidade do subsistema estrutura das habitações. Com isso se delimita o campo de estudo do trabalho que nada mais é que a Patologia observada na edificação, ocasião em que se procurou delinear sua causa e mecanismos de ocorrência.

No Capítulo 2 são abordados os conceitos de durabilidade para o concreto armado em si e finalmente os possíveis problemas que surgem nas estruturas.

$\mathrm{O}$ terceiro capítulo trata de questões sobre patologia: conceitos; retrospectiva das maiores incidências comumente observadas; $\mathrm{o}$ aspecto geral do que tem ocorrido de patologias pelo País.

No quarto capítulo discorre-se sobre a metodologia que foi elaborada para a realização da pesquisa, onde se explica a conduta que foi utilizada para a realização dos trabalhos de campo até a fase final de conclusão.

No quinto capítulo são apresentados os resultados coletados no campo, podendo-se, a partir daí, classificar e enumerar as diversas incidências patológicas encontradas nas construções visitadas.

No sexto capítulo são discutidas as questões com base na expedição realizada no campo, instante em que se procurará estabelecer o juízo das situações observadas, diagnosticando o comportamento, do ponto de vista patológico, das tendências que ocorrem na região.

No sétimo capítulo, posteriormente à análise final dos fatos, são apresentadas as principais conclusões e estabelecem-se as propostas futuras mostrando-se condutas que devem ser tomadas para novas técnicas e tecnologias que surgirão ou que já começam a despontar em relação ao que foi vivenciado neste trabalho. 
No oitavo capitulo apresenta-se a bibliografia consultada que viabilizou 0 desenvolvimento do tema proposto.

Finalmente, como texto complementar, são incorporadas as tabelas com os resultados obtidos em campo na íntegra, sob forma de anexo, com o intuito de completarem possiveis esclarecimentos. 


\section{DURABILIDADE DAS ESTRUTURAS DE CONCRETO}

\section{1 - DEFINIÇÕES E CONCEITOS DE DURABILIDADE:}

Uma estrutura que atenda aos requisitos mínimos de desempenho ao longo do tempo, conforme previsto em projeto, para os fins que foi projetada pode ser considerada durável. Uma vez que durabilidade sob um conjunto de condições não significa necessariamente durabilidade sob outro conjunto, costuma-se incluir uma referência geral ao ambiente ao definir-se durabilidade. De acordo com o Comitê 201 do ACI, durabilidade do concreto de cimento Portland é definida como a sua capacidade de resistir à ação das intempéries, ataques químicos, abrasão ou qualquer outro processo de deterioração; isto é, o concreto durável considerará a sua forma original, qualidade e capacidade de utilização quando exposto ao seu meio ambiente.

Nenhum material é inexoravelmente durável; como um resultado de interações ambientais, a microestrutura $\mathrm{e}$, consequentemente, as propriedades dos materiais mudam com o passar do tempo. Admite-se que um material atingiu o fim da sua vida útil quando as suas propriedades sob determinadas condições de uso deterioram a um tal ponto que a continuação do uso deste material é considerada, como insegura, ou antieconômica.

De outra forma, pode-se pensar que o estabelecimento, em projeto, da vida útil de uma estrutura pode variar, por exemplo, de 5 anos (estruturas de apoio em canteiros de.obra) até 100 anos ou mais (caso de obras especiais).

METHA \& MONTEIRO (1994) salientam que esta durabilidade é avaliada pelo período de tempo que essa estrutura é colocada em serviço (vida útil).

Alguns autores brasileiros, tomando por base documentos existentes, apresentam algumas definições sobre durabilidade. SOBRAL (1990) por exemplo 
define que "A durabilidade de um concreto é a sua capacidade de resistir aos agentes destrutivos e comportar-se satisfatoriamente durante um determinado período de tempo. Esta propriedade depende das condições ambientais, de um lado, e da qualidade do concreto, do outro".

De maneira geral, HELENE (1987a) descreve que para as estruturas de concreto deve-se considerar os seguintes aspectos:

- agressividade do meio ambiente (ao concreto e à armadura);

- classificação da resistência do concreto a um determinado tipo de agente agressivo;

- modelos (preferencialmente matemáticos) de deterioração e envelhecimento das estruturas de concreto;

- correspondência entre a agressividade do meio e a resistência à deterioração da estrutura de concreto;

- a vida útil desejada.

Segundo PALERMO (1995), apesar de existirem algumas definições sobre durabilidade dadas por normas estrangeiras, não há atualmente nenhuma metodologia de ensaio universalmente aceita para caracterizar a estrutura porosa do concreto ou para relacioná-la à sua durabilidade. De acordo com o mecanismo de deterioração são especificadas metodologias, combinadas ou isoladamente como:

- absorção por imersão e fervura (NBR 9778 ou ASTM- C-642);

- penetração de água sob pressão (NBR 10787 ou ENV 206)

- resistividade elétrica volumétrica e absorção por capilaridade (NBR 9779);

- permeabilidade a gases (método Cembureau ou KT- não são normalizados).

No Brasil ainda não existe norma específica que defina durabilidade.

Porém, atualmente a NBR-6118, que se encontra em processo de revisão no âmbito do Comitê Brasileiro da Construção Civil - CB-2 da Associação Brasileira de 
Normas Técnicas, recebe entre outras propostas a incorporação de um capítulo que aborde somente a durabilidade das estruturas correntes de concreto.

Dentro dessas recomendações, DINIZ (1998) expõe que quanto às exigências de durabilidade, as estruturas devem ser projetadas, construídas e utilizadas de modo que, sob as condições ambientais previstas e respeitadas as condições de manutenção preventiva especificadas no projeto, conservem sua segurança, estabilidade, aptidão em serviço e aparência aceitável, durante um período pré-fixado de tempo, sem exigir medidas extras de manutenção e reparo.

Além disso, incorpora-se que a durabilidade de uma estrutura passa a depender da cooperação mútua de seis responsáveis:

- o proprietário: definindo suas expectativas presentes e futuras de uso da estrutura;

- o responsável pelo projeto arquitetônico: definindo detalhes e especificando materiais;

- o responsável pelo projeto estrutural: definindo geometrias, detalhes e especificando materiais e manutenção preventiva;

- o responsável pela tecnologia do concreto: definindo características de materiais, traços e metodologia de execução, em conjunto com os responsáveis pelos projeto estrutural e responsável pela construção;

- o responsável pela construção: definindo metodologias complementares da construção e respeitando o projetado e especificado anteriormente;

- e finalmente o proprietário/usuário obedecendo as condições de uso, de operação e de manutenção preventiva especificadas.

\section{2 - VIDA ÚTIL}

A vida útil de um material ou componente pode ser definida como o período durante o qual as propriedades desse material ou componente permanecem acima de limites mínimos admissíveis.

Esses limites mínimos admissíveis variam em função das condições a que os materiais e componentes estejam expostos ou submetidos. Por exemplo, um concreto projetado com determinada composição de materiais e resistência mecânica pode 
apresentar um desempenho variado, dependendo do grau de exposição: local, meio ambiente, microrregião, compatibilidade de materiais, etc.

Sendo assim, partindo-se da premissa que todos os fatores intervenientes foram considerados, a vida útil de um material ou componente é obtido através de uma análise estatística, conforme a Figura 04:

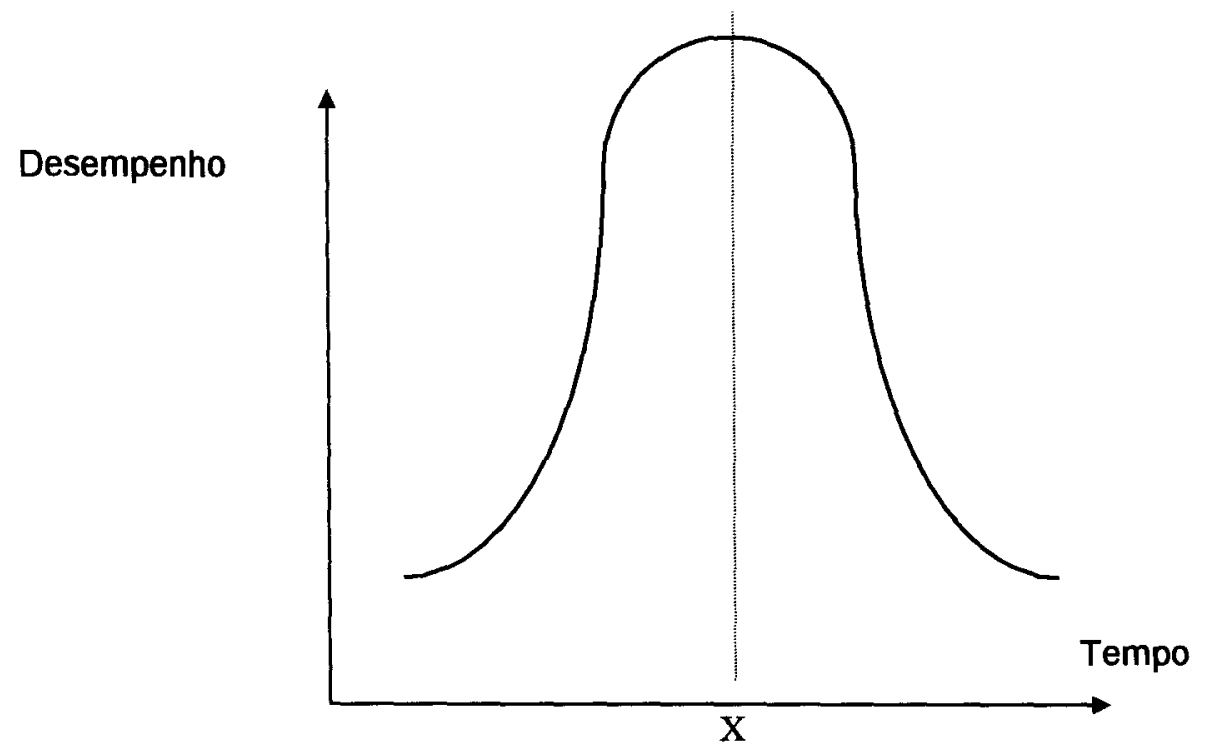

FIGURA 04 - Vida útil em função da distribuição estatística normal de componentes - Fonte: LICHTENSTEIN, 1985

DINIZ (1998) relata que a proposta de texto da revisão da NB-1 passa a entender que a vida útil de projeto é o período de tempo ao qual as estruturas de concreto mantêm as características exigidas para sua durabilidade alem da vida útil passar a ser relacionada também a partir de critérios criados pelos seis responsáveis pela estrutura.

Ë colocado ainda que "o conceito de vida útil aplica-se à estrutura como um todo ou às suas partes. Dessa forma, determinadas partes das estruturas podem merecer consideração especial com valor de vida útil diferente do todo".

Tomando como referência o CEB/FIP Model Code 1990, por vida útil entende-se o periodo de tempo no qual a estrutura é capaz de desempenhar as funções para as quais foi projetada sem necessidade de intervenções não previstas, ou seja, as operações de manutenção previstas e especificadas ainda na fase de projeto, fazem 
parte do período total de tempo durante o qual se admite que a estrutura está cumprindo bem sua função.

A partir do modelo clássico proposto por Tuutti em 1982, HELENE (1993) propôs uma conceituação e definição de vida útil conforme Figura 05 distinguindo três situações e suas correspondentes vidas úteis que apesar de enfatizar o fenômeno da corrosão por ser o mais freqüente e conhecido pode ser aplicado a todos os mecanismos de deterioração.

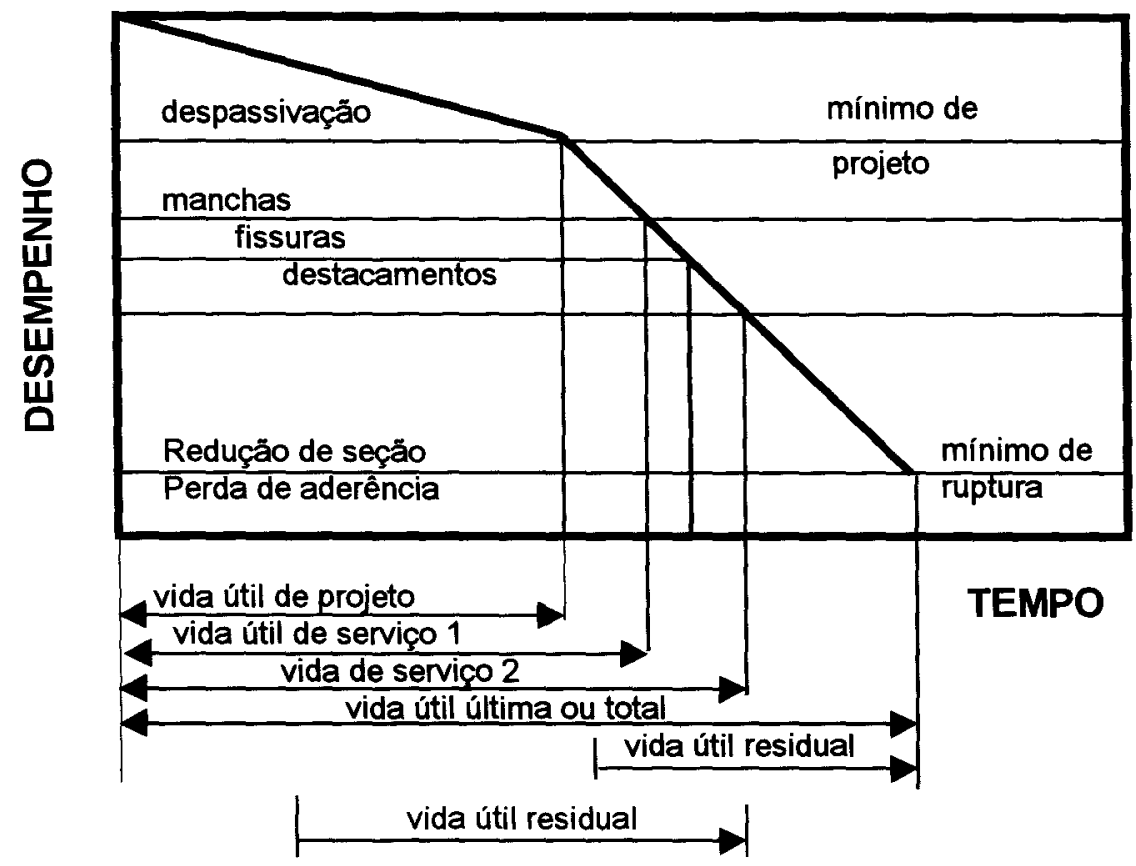

FIGURA 05 - Conceituação de vida útil das estruturas de concreto tomando-se por referência o fenômeno de corrosão de armaduras (Fonte: HELENE, 1998).

Como pode ser observado pela figura acima, podem ser definidas as seguintes vidas úteis:

- vida útil de projeto que compreende o período de tempo que chega até a despassivação da armadura. Isso não significa que necessariamente a partir desse instante haverá corrosão significativa. Esse periodo de tempo é o. período que deve ser adotado no projeto da estrutura;

- vida útil de serviço ou de utilização que compreende o aparecimento de manchas na superficie do concreto, fissuras no concreto de cobrimento ou ainda o surgimento do destacamento desse concreto de cobrimento. Esse fato varia de 
caso a caso sendo que em alguns casos somente depois da queda de pedaços de concreto, colocando em risco a integridade da estrutura ou usuários, é que pode se definir como terminada a vida útil de serviço;

- vida última ou total é o período de tempo que vai até a ruptura ou colapso parcial ou total da estrutura;

- por último, introduziu-se o conceito de vida útil residual que corresponde ao período de tempo em que a estrutura ainda é capaz de desempenhar suas funções considerado a partir da data de uma vistoria qualquer realizada.

HELENE (1998) menciona que hoje, apesar de não haver especificações e metodologias normalizadas para estimativa de vida útil, existem métodos que são empregados para se prever a vida útil de uma estrutura.

Essa previsão pode ser feita através de métodos com base em ensaios acelerados, métodos deterministas e finalmente através de métodos estocásticos ou probabilistas.

\section{3 - MANUTENÇÃO DAS CONSTRUÇÕES}

A primeira tendência de todo material, que exigiu energia para sua elaboração, é passar de uma forma termodinamicamente instável, para uma situação estável. Essa estabilidade é conseguida através de sua volta ao seu estado natural, como se encontra na natureza.

Os concretos têm sido produzidos com $11<\mathrm{pH}<12,5$, extremamente básico e necessitam para isso uma elevada aplicação de energia, permanecendo numa situação instável, que por sua vez tenderá a assumir uma situação estável.

Essa característica portanto, para a maioria dos materiais, está associada à sua degradação. $O$ importante nesse caso é a interferência no sentido de reduzir a velocidade com que isso ocorre, associando-se a uma condição de vida útil previamente estabelecida.

Isso se consegue com o estabelecimento de proteções às construções, realçando-se o comportamento de um ou mais parâmetros associados ao meio ambiente e, sua manutenção periódica, estabelecida em cada caso. 
O programa de manutenção, por sua vez, estará associado também com a tipologia da obra, visto que no projeto a escolha dos materiais e a composição final do produto, para cada caso, deverá estar associada à responsabilidade e riscos que a obra irá oferecer às pessoas e ao próprio meio ambiente. Essa situação pode ser vista abaixo:

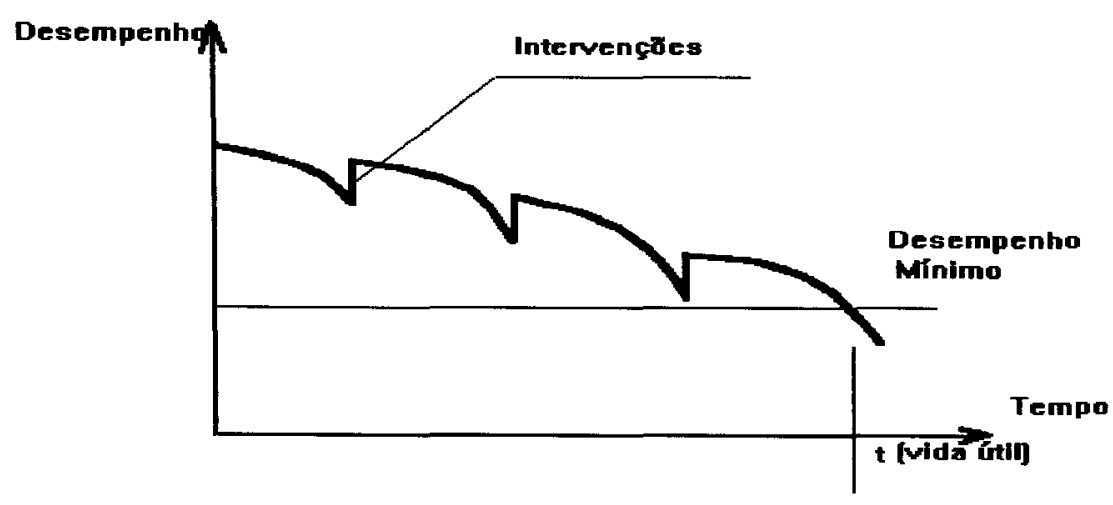

FIGURA 06 - Relação entre desempenho, manutenção e vida útil, Fonte: LICHTENSTEIN, 1985

Como observado na Figura 06, torna-se imperativo afirmar que passado determinado tempo, a construção vai apresentar um desempenho insatisfatório. A ocorrência dessa situação, fazendo-se analogia com o significado de vida útil, obtida através de uma análise estatística, a questão das condições de exposição a que uma obra de mesma tipologia fica exposta, com variáveis condições ambientais (sítios diferentes), culmina por interferir no tempo de vida da obra sob condições de desempenho satisfatório.

De outra forma, os projetos inadequados, execuções mal elaboradas, uso inadequado com relação à propositura inicial prevista no projeto, etc., podem levar a desempenhos insatisfatórios em curto espaço de tempo.

Em certas ocasiões, é necessário que se façam grandes intervenções em construções-problema, a fim de que ela atinja um nível satisfatório de desempenho e possa ser utilizada.

Ressalta-se no entanto que, geralmente, os custos dessas intervenções tornamse extremamente elevados o que inviabiliza sua revitalização. 
Assim sendo, torna-se oportuno se ter em mente que as intervenções e manutenções tornam-se viáveis até o instante em que, ou se justifique plenamente a aplicação de recursos vultosos comparativos ao valor cultural da obra ou, inviáveis quando esse custo torne-se tal que para um prolongamento de um curto período de tempo de desempenho satisfatório, haja necessidade de grandes investimentos.

A Figura 07 retrata essa situação, onde o tempo $t_{1}$ refere-se a um período de amaciamento da construção $e, t_{2}$ representa a vida útil (custo de manutenção alto $X$ pequeno acréscimo na utilização do produto em condições de desempenho satisfatório), onde para a retomada de desempenho, através das intervenções, os custos de manutenção e reparos, tornam-se extremamente elevados e são eficientes em curto espaço de tempo. Por outro lado, procura-se durante o tempo $t_{1}$, realizar todas as correções que serão menos onerosas nesse instante pelo fato de que essa observação poderá ser o ponto de origem de degradação e comprometimento de outros subsistemas.

Por exemplo, um falha no sistema de impermeabilização de uma fachada que propiciará, num futuro não distante, o comprometimento, na situação de uso, dos subsistemas: pinturas, revestimentos argamassados, revestimentos de madeira, tecidos, sistema elétrico, estrutura, etc. Muitas vezes, as correções nesse instante $t_{1}$ ocorrerá anteriormente à utilização da construção.

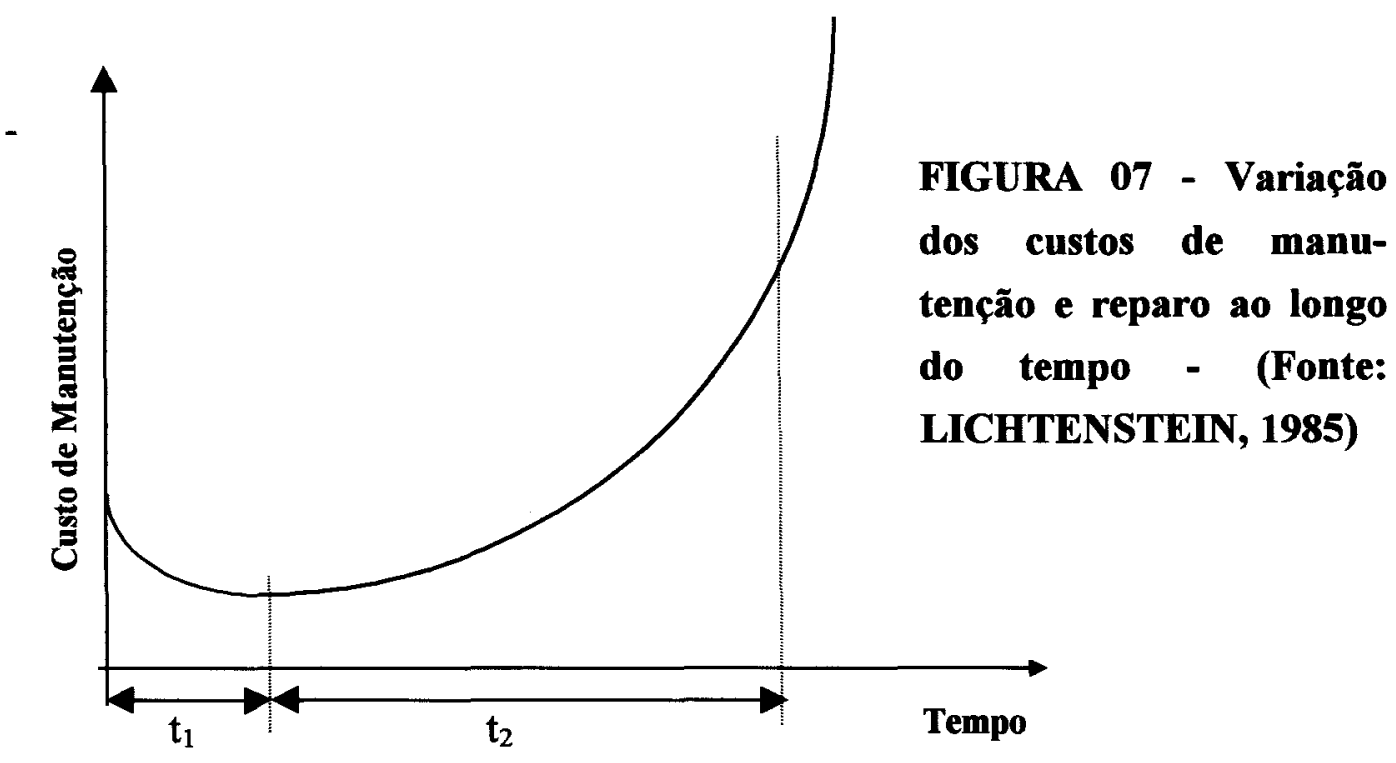




\section{4 - FATORES QUE INFLUENCIAM A DURABILIDADE DO} CONCRETO

METHA \& MONTEIRO (1994) apresentam a água como fator central para a maioria dos problemas de durabilidade, pois esta causa muitos tipos de processos fisicos de degradação. Em segundo lugar, os fenômenos fisicos e químicos associados com os movimentos da água (contendo íons agressivos) em sólidos porosos (concreto) que são controlados pela permeabilidade do sólido. Ou seja, o fluxo de líquidos, íons e gases no concreto estão diretamente ligados à durabilidade deste e a sua resistência mecânica.

Sendo assim, o estudo da permeabilidade é de suma importância.

\subsection{1 - POROSIDADE E PERMEABILIDADE}

O termo permeabilidade tem sido usado para diferentes propriedades e tem sido, algumas vezes, confundido com porosidade. A Figura 08 permite ilustrar as diferenças entre porosidade e permeabilidade.

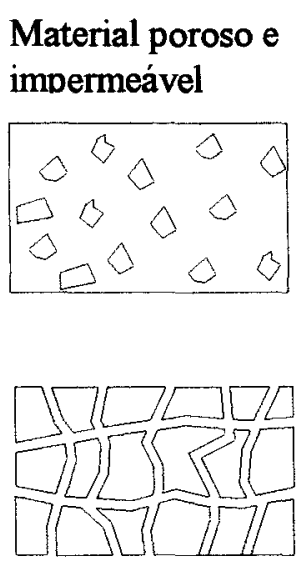

Material poroso e permeável
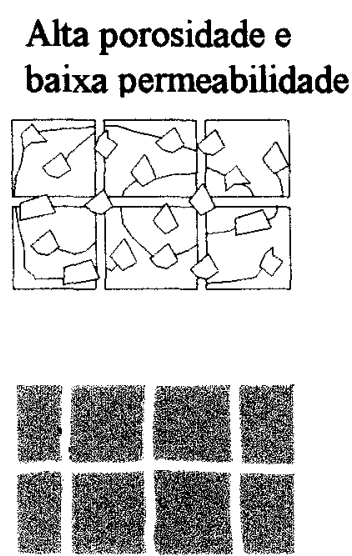

Baixa porosidade e alta permeabilidade
FIGURA 08 - Esquema ilustrativo sobre porosidade $e$ permeabilidade (Fonte: Oliveira \& Helene; "Proteção e Manutenção das Estruturas de Concreto". Rev. Engenharia, n485, p. 13, São Paulo/1991).

\subsubsection{1. - POROSIDADE}

É um fenômeno que se correlaciona com o volume, distribuição e características de poros que podem ou não ser interconectados. Isto significa que o 
material pode possuir poros internos, não permitindo, porém, a passagem de água através destes.

Segundo OLIVIER (1998) em termos de durabilidade, as características mais importantes da porosidade média são o diâmetro dos poros e a conectividade de um sistema poroso.

O autor realizou ensaios de penetração de mercúrio em amostras para diferentes períodos de hidratação com um mesmo fator água/cimento e constatou que o diâmetro dos poros diminui em função da hidratação dos produtos. Porém a distribuição dos poros também é uma função que varia com a relação água/cimento, pois em uma pasta de cimento fresca, no seus primeiros instantes, os espaços que ficam entre os grãos de cimento são afetados pela água contida.

Quando se analisa a influência das adições nas pastas de cimento, $o$ autor frisa que nas primeiras idades, a porosidade e o tamanho dos poros aumenta quando se utiliza cinzas volantes ou escória granulada; isso ocorre em função de uma hidratação lenta. Em contrapartida, quando se analisou essas pastas para longos períodos, as características da pasta melhoraram apresentando uma porosidade menor além de diminuírem os diâmetros dos poros.

OLIVIER (1998) menciona ainda o efeito benéfico da utilização da sílica ativa. Ao analisar seus efeitos sob a pasta de cimento endurecida verificou-se a diminuição tanto da porosidade quanto do diâmetro dos poros quando se empregam as adições referidas e aditivos compatíveis.

\subsubsection{2. - PERMEABILIDADE}

A permeabilidade é a vazão de água através de um corpo dada uma certa pressão e temperatura. Essa vazão depende do tamanho, da continuidade dos poros e da sua distribuição e não somente da porosidade em si.

Segundo NEVILLE (1982) qualquer fator que modifique essa porosidade influencia na permeabilidade. Alguns fatores a serem citados são: a dosagem de cimento e água no concreto, a aderência pasta-agregado, grau de hidratação da pasta, tipo de agregado utilizado, adições e aditivos entre outros. 
SOBRAL (1990) acrescenta que o fluxo de água no concreto é semelhante ao fluxo através de qualquer corpo poroso. Primeiramente uma dada quantidade de água penetra no sólido pela pressão externa e pelas forças capilares, até que se sature cessando as forças capilares e estabelece um fluxo que pode ser avaliado pela lei de Darcy:

$$
\mathrm{Q}=\mathrm{K} \bullet \mathrm{i} \bullet \mathrm{A}
$$

Onde $: Q=$ vazão

$\mathrm{K}=$ coeficiente de permeabilidade de Darcy

$\mathrm{i}=\Delta \mathrm{H} / \mathrm{L}=$ gradiente hidráulico;

$\mathrm{A}=$ área

Nessa expressão, SOBRAL (1990) salienta que o coeficiente de permeabilidade (K) é que vai controlar esse fluxo através do concreto.

O termo permeabilidade é estritamente relacionado com o fluxo que ocorre sob a aplicação de uma pressão diferencial.

Para uma análise macroscópica da permeabilidade considera-se a seguir a permeabilidade da pasta de cimento, a permeabilidade dos gases, a permeabilidade do agregado e finalmente a permeabilidade do concreto.

\subsubsection{2.a - Permeabilidade da pasta}

De acordo com SOBRAL (1990), em uma pasta de cimento endurecida o tamanho e a continuidade dos poros que aparecem durante a hidratação, é que irão controlar o coeficiente de permeabilidade $(\mathrm{K})$ onde a água adicionada ao cimento é responsável indireta pela formação desses poros e consequentemente desta permeabilidade. O mecanismo apresentado por METHA \& MONTEIRO (1994) para a formação dos poros numa pasta de cimento é:

- a pasta de cimento recém misturada possui grande quantidade e continuidade de poros tendo um coeficiente de permeabilidade (K) grande;

- inicia a hidratação da pasta de cimento e os poros vão sendo segmentados diminuindo o coeficiente de permeabilidade $(\mathrm{K})$; 
- após a total hidratação da pasta de cimento, $30 \%$ da porosidade capilar é alcançada, ou seja, para uma porosidade capilar na pasta menor que esse valor o coeficiente de permeabilidade não apresenta uma diminuição substancial.

A quantidade de água na pasta é indiretamente responsável pela permeabilidade já que, segundo SOBRAL (1990), determina o espaço total e posteriormente o espaço vazio devido as reações de hidratação, onde quanto maior a relação água/cimento, um número elevado de poros grandes e bem conectados o concreto irá conter, e maior tempo para atingir a descontinuidade da rede capilar $(30 \%)$.

$\mathrm{Ou}$ seja, a permeabilidade da pasta de cimento depende da relação água/cimento e do grau de hidratação do mesmo. Em geral, quando a relação água/cimento é alta e o grau de hidratação é baixo, a pasta terá alta porosidade capilar; ela conterá um número relativamente elevado de poros grandes e bem conectados e, portanto, o seu coeficiente de permeabilidade será alto.

\subsubsection{2.b - Permeabilidade aos gases}

A permeabilidade aos gases de boas argamassas e concretos é tão baixa, que são raras as determinações precisas dessa propriedade. Sob iguais gradientes de pressão, o oxigênio deve penetrar através do concreto mais rapidamente que o $\mathrm{CO}_{2}$, vapor de $\mathrm{H}_{2} \mathrm{O}$ ou água, devido às suas características moleculares, mas dificilmente os gradientes de pressão são elevados (RILEM, 1976). A pressão parcial dos gases agressivos no ar é muito baixa - para o $\mathrm{CO}_{2}$ da ordem de $10^{-4} \mathrm{MPa}$ - pois dependem de sua concentração no ar, que também é baixa comparativamente à concentração do $\mathrm{O}_{2}$ e $\mathrm{N}_{2}$.

$\mathrm{O}$ dióxido de carbono $\left(\mathrm{CO}_{2}\right)$ parece não penetrar no concreto além da zona carbonatada, sendo sua pressão de contato proporcional ao teor de $\mathrm{CO}_{2}$ da atmosfera. A permeabilidade ao $\mathrm{CO}_{2}$ diminui com a carbonatação do concreto, que tende a colmatar os poros dos capilares.

A permeabilidade aos gases agressivos reveste-se de importância quando se trata, por exemplo, de lajes e partes superiores de interceptores de esgoto. $O$ fluido 
transportado pode gerar sulfetos $\left(\mathrm{S}^{-}\right)$inicialmente em forma de gás sulfídrico $\mathrm{H}_{2} \mathrm{~S}$. Ao estar em contato com o concreto e na presença de bactérias aeróbias, esses gases podem oxidar-se, transformando-se em $\mathrm{H}_{2} \mathrm{SO}_{4}$ e contribuindo para a aceleração da corrosão.

A permeabilidade aos gases diminui nos concretos em ambientes úmidos, pois, além da eventual formação superficial de microfissuras de retração, a umidade e a água presentes nos poros dificultam o movimento dos gases. Daí o fato consagrado de observarem-se maiores profundidades de carbonatação em ambientes secos (U.R.< $80 \%$ ), ou submetidos a ciclos de secagem e umidecimento.

\subsubsection{2.c- Permeabilidade do agregado}

Segundo METHA \& MONTEIRO (1994) o volume de poros na maioria dos agregados naturais está normalmente abaixo de $3 \%$ e raramente excede $10 \%$ quando comparados à porosidade capilar de 30 a $40 \%$ das pastas típicas de cimento em concreto endurecido. Os autores, baseados em pesquisas feitas por POWERS (1958), mostram na Tabela 01 que o coeficiente de permeabilidade $(\mathrm{K})$ dos agregados variam da mesma forma que os coeficientes de permeabilidade da pasta de cimento endurecida.

TABELA 01 - Comparação entre permeabilidade de agregados (rochas) e pasta de cimento Portland (POWERS,1958 \& POWERS apud NEVILLE, 1976).

\begin{tabular}{ccc}
\hline Tipo de Rocha & $\begin{array}{c}\text { Coeficiente de } \\
\text { permeabilidade }(\mathrm{cm} / \mathrm{s})\end{array}$ & $\begin{array}{c}\text { relação a/c da pasta hidratada com o } \\
\text { mesmo coeficiente de } \\
\text { permeabilidade }\end{array}$ \\
\hline Basalto denso & $2,47 \times 10^{-12}$ & 0,38 \\
\hline Diorito de quartzo & $8,28 \times 10^{-12}$ & 0,42 \\
\hline Mármore & $2,39 \times 10^{-11}$ & 0,48 \\
\hline Mármore & $5,77 \times 10^{-10}$ & 0,66 \\
\hline Granito & $5,35 \times 10^{-9}$ & 0,70 \\
\hline Arenito & $1,23 \times 10^{-8}$ & 0,71 \\
\hline Granito & $1,56 \times 10^{-8}$ & 0,71 \\
\hline
\end{tabular}


Através da Tabela 01, deve-se observar que para pastas com mesmo coeficiente de permeabilidade do agregado a relação água/cimento é proporcional ao coeficiente de permeabilidade do agregado. Ou seja, a relação água/cimento mais baixa se relaciona com o menor coeficiente de permeabilidade do agregado. Assim sendo, pode-se afirmar que o coeficiente de permeabilidade da pasta é menor que 0 do agregado.

Segundo METHA \& MONTEIRO (1994), a razão pela qual alguns agregados com baixa porosidade apresentam permeabilidade muito maior que em pastas de cimento é que o tamanho dos poros capilares nos agregados é normalmente muito maior estando na faixa de $10 \mu \mathrm{m}$ enquanto que as pastas estão na ordem de $10 \mathrm{~nm}$ a $100 \mathrm{~nm}$.

\subsubsection{2.d - Permeabilidade dos concretos}

Segundo HELENE (1986), os concretos terão permeabilidade maior que a da pasta pura e totalmente curada; porém, em geral, menor que a permeabilidade dos agregados com os quais foram preparados.

Essa maior impermeabilidade das pastas - segundo alguns pesquisadores deve-se ao efeito de tamponamento e obturação pelo gel de cimento e à menor dimensão dos capilares, apesar destes serem, via de regra, em maior número que os presentes nas rochas.

De acordo com o que foi apresentado anteriormente, se forem utilizados agregados com baixa permeabilidade juntamente com a pasta de cimento; a permeabilidade do sistema deveria diminuir, pois estes agregados interceptam fluxo dentro da matriz da pasta. Todavia, segundo METHA \& MONTEIRO (1994), a permeabilidade da argamassa ou concreto é maior que a permeabilidade da pasta, devido microfissuras presentes na zona de transição entre o agregado e a pasta de cimento.

Conforme os autores, o tamanho e a granulometria do agregado afetam as características de exsudação de uma mistura de concreto, a qual, por sua vez, influencia a resistência da zona de transição (exsudação interna). 
Nesse aspecto, PAULON (1996) salienta ainda que na região de contato entre a pasta de cimento e o agregado, quanto menor a incidência de fissuras nessa zona de transição menor a permeabilidade do concreto e maior a durabilidade.

PAULON (1996) apresenta ainda que a zona de transição contém cristais maiores e em maior quantidade que aqueles encontrados na massa de cimento hidratado, além do fato desses cristais mostrarem uma orientação preferencial, o que é um aspecto favorável à propagação de fissuras. Pelas razões expostas, a zona de transição é a parte mais fraca do concreto endurecido sendo nesta a ocorrência das primeiras ações irreversíveis resultando em microrrupturas quando houver compressão e fissuração e fechamento de poros quando sujeita à tração ou ao cisalhamento.

Uma vez iniciada a fissuração, esta se propaga de uma zona de transição para a outra, onde na maioria dos casos a fratura segue o contorno dos agregados, facilitando a entrada de agentes agressivos no interior do concreto, para o caso dos concretos convencionais.

SOBRAL (1990) acrescenta ainda em relação à permeabilidade do concreto, que quando há um excesso de água, um determinado número de grãos de agregados tem parte da sua superfície praticamente descolada da pasta, devido a água impedir a aderência da mesma ao agregado (exsudação interna). Assim, quanto menor for a possibilidade de deslocamento na sua superfície de contato, menor será a percolação através dessa superficie.

Devido à grande importância da zona de transição na ligação pasta-agregado, estudos estão sendo realizados visando melhorar o desempenho dessa zona de transição.

No entanto, já é conhecido que se aumentando a coesão das pastas através do uso de adições e aditivos, esse efeito é praticamente eliminado. 


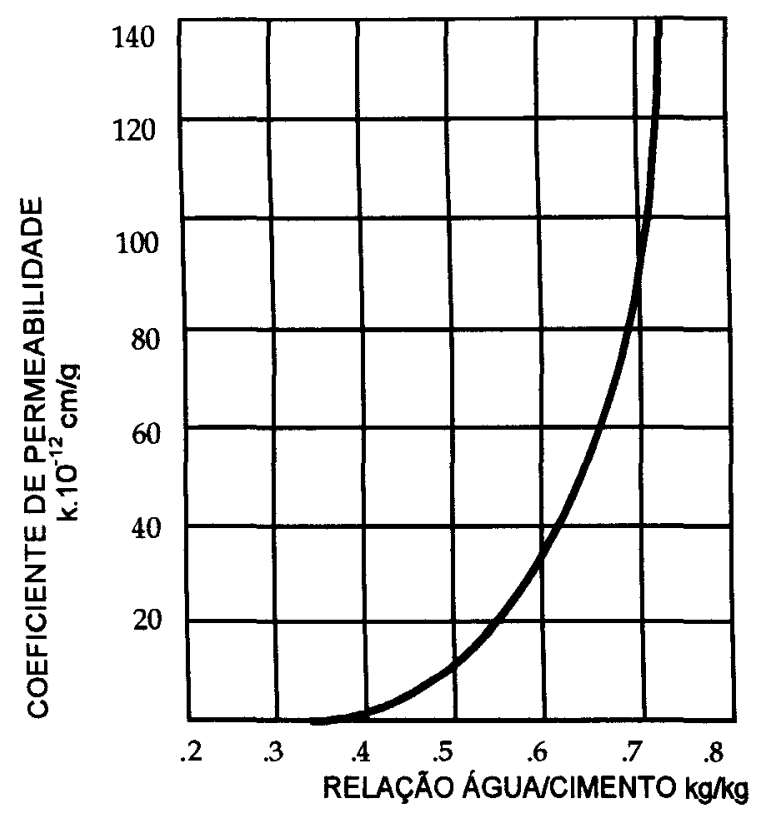

FIGURA 09 - Influência da relação água/cimento na permeabilidade de pastas de cimento Portland altamente hidratadas (93\%) (POWERS,1958,\& POWERS apud NEVILLE, 1976).

A nível ilustrativo, tomando a Figura 09 como referência, pode-se fazer uma analogia ao correlacionar as resistências dos concretos com suas permeabilidades. Mesmo com a permeabilidade da argamassa ou concreto ser maior que a da pasta, os coeficientes apresentam mesmo comportamento proporcionalmente. Assim sendo, segundo as classificações de resistência orientadas por HELENE (1998), um concreto com classe de resistência efềmera $(\mathrm{C} 10$ a $\mathrm{C} 20)$ e relação $\mathrm{a} / \mathrm{c} \geq 0,62$ apresenta um coeficiente de permeabilidade por volta de $40 \bullet 10^{-12} \mathrm{~cm} / \mathrm{g}$, enquanto que, para um concreto resistente ( $\mathrm{C} 35$ a $\mathrm{C} 45)$ com relação $\mathrm{a} / \mathrm{c}=0,50$, esse apresenta um coeficiente de permeabilidade por volta de $18 \bullet 10^{-12} \mathrm{~cm} / \mathrm{g}$ e para concretos duráveis (C50) com relação $\mathrm{a} / \mathrm{c} \leq 0,38$, o coeficiente de permeabilidade chega a praticamente zero.

Como a maioria dos concretos encontrados usualmente nas nossas obras apresentam classes de resistência variando de $\mathrm{C} 10$ a C20, pode-se concluir que grande quantidade de nossas estruturas apresentam concretos de baixíssima qualidade, com alta porosidade, grande permeabilidade e consequentemente baixas características de durabilidade. Possivelmente esta é a explicação pela grande quantidade de obras que apresentam problemas de corrosão de armaduras. 


\subsection{2 - Adsorção}

Segundo OLIVEIRA \& HELENE (1991), é um processo no qual moléculas de água se aderem à superficie do concreto. Na adsorção fisica, as moléculas de água ficam aderidas à superficie do adsorvente devido a forças de Van der Waals. Na adsorção química, as moléculas de água são adsorvidas como resultado de uma reação química.

\subsection{3 - Absorção}

OLIVEIRA \& HELENE (1991) colocam que é um processo pelo qual o concreto absorve um fluido para preencher espaços vazios internos no material, através de tensões capilares.

A absorção de água do concreto é um dos fatores mais dificeis de serem controlados. Em princípio, quanto menor for o diâmetro dos capilares, maior as pressões capilares e consequentemente, maior e mais rápida absorção da água.

Reduções na relação água/cimento parecem contribuir para reduzir a absorção, porém, à medida que tornam o concreto mais denso e compacto, diminuem o diâmetro dos capilares e, desde que estes sejam intercomunicáveis, podem aumentar a absorção dos capilares (altura da coluna). Porém, as pesquisas tem demonstrado que nesse caso, a importância desses capilares não são significativos para a durabilidade. No outro extremo, concretos porosos absorvem pouca água por capilaridade, mas acarretam outros problemas insuperáveis de permeabilidade e carbonatação acentuada.

Aditivos impermeabilizantes incorporados à massa de concreto e revestimentos externos hidrófugos podem reduzir drasticamente o risco de absorção de água prejudicial como no caso dos pés de pilares e estruturas semi-enterradas e consequentemente nas armaduras contíguas nessas estruturas. De qualquer forma, é sempre conveniente aumentar os cobrimentos do concreto, quando se está diante de situações de risco de absorção de águas agressivas às armaduras de aço.

Finalmente, deve ser considerado o fato de maior ou menor grau de saturação do concreto, ou seja, não há absorção de água em concretos saturados, porém pode ocorrer o fenômeno da difusão minimizando-a. Em peças pré-moldadas ou elementos que já 
tiveram oportunidade de entrar em equilíbrio com o meio ambiente, secam-se parcialmente, sendo portanto, inevitável a absorção d'água.

O fenômeno da difusão é um processo através do qual um líquido, gás ou íon, pode passar através do concreto, sob a ação de um gradiente de concentração. Este gradiente é definido para cada tipo de material como um "coeficiente de difusão" ou "medida de difusividade".

O processo será mais intenso quanto maior o gradiente de concentrações de elementos dissolvidos nos meios aquosos dos poros de concreto como quanto do meio ambiente, tendendo a um equilíbrio. Daí o fato já conhecido de que meios muito permeáveis com renovação da água em contato (areias e águas em movimento), são muito mais agressivos que ambientes onde a velocidade de renovação é baixa ou nula (argilas e águas estagnadas).

Sendo a difusão um fenômeno de transporte de massa através de um fluido, é de se esperar que o processo diminua quanto mais compacto for o concreto.

\subsection{CLASSIFICAÇÃo DAS CAUSAS DE DETERIORAÇÃo dO CONCRETO}

METHA \& MONTEIRO (1994) agruparam as causas fisicas em duas categorias: desgaste superficial devida a abrasão, cavitação ou erosão e fissuração devido a diferentes gradientes de temperatura e umidade e carregamento estrutural. Da mesma forma agruparam as causas químicas em três categorias: hidrólise dos componentes da pasta de cimento por água pura, trocas iônicas entre fluidos agressivos e a pasta de cimento e reações causadoras de produtos expansíveis. Essa classificação pode ser melhor visualizada conforme a Figura 10 mostrada a seguir.

Deve-se ressaltar que a distinção entre as causas fisicas e químicas de deterioração é arbitrária pois as duas se sobrepõem, ou seja, geralmente uma deterioração de causa física acarretará em uma deterioração de causa química e vice-versa. 


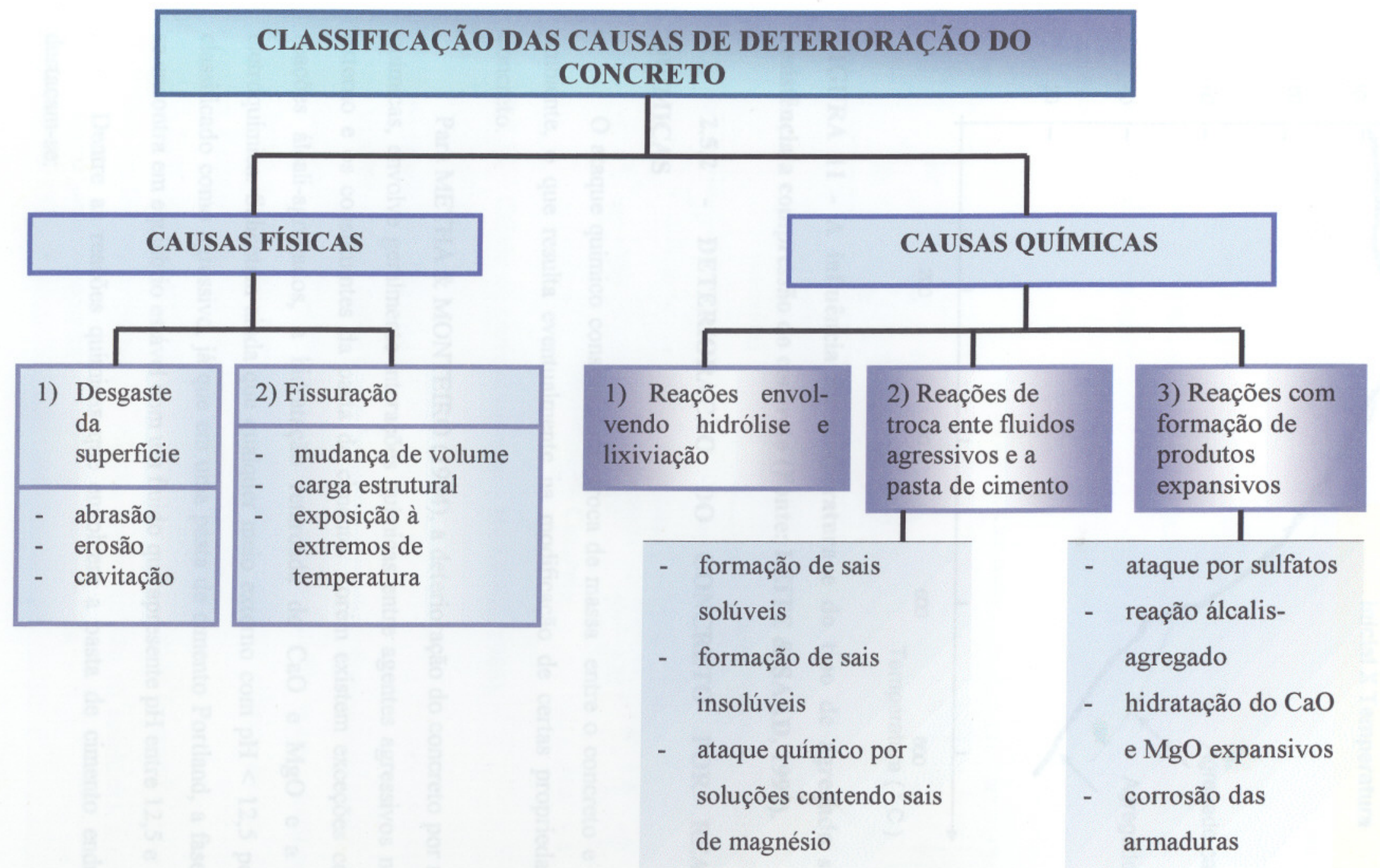

FIGURA 10 - Classificação das causas de deterioração do concreto ( METHA \& MONTEIRO, 1994). 


\subsection{1 - DETERIORAÇÃO DO CONCRETO POR AÇÕES FÍSICAS}

As causas físicas para a deterioração do concreto são classificados em: desgaste superficial e fissuração de acordo com METHA \& MONTEIRO (1994).

\subsubsection{1 - Deterioração devido ao desgaste superficial}

A perda de massa a partir da superficie de concreto pode ocorrer progressivamente, devido à abrasão, erosão e cavitação ou ainda lixiviação.

A abrasão refere-se principalmente ao atrito seco, tal como desgaste de pavimentos e pisos industriais devido ao trafego de veículos.

A pasta de cimento endurecida não possui uma alta resistência ao atrito. A vida útil do concreto pode ser significativamente diminuída, sob condições de ciclos de atrito repetidos, especialmente quando a pasta de cimento tem alta porosidade ou baixa resistência e é protegida inadequadamente por um agregado de baixa resistência ao desgaste.

A erosão é usada para descrever a ação de fluidos contendo partículas sólidas, que ocorre principalmente em estruturas hidráulicas tais como vertedouros, canais e condutos.

Um fluido contendo partículas sólidas em suspensão ao entrar em contato com o concreto, pode causar desgaste superficial através da ação de escorregamento, rolamento ou colapso das partículas. A velocidade de erosão superficial depende da porosidade ou resistência do concreto e, evidentemente, da quantidade, tamanho, forma, densidade, dureza e velocidade das partículas.

A cavitação ocorre devido ao colapso de bolhas de vapor sobre superficies de concreto, predominantemente em estruturas contendo água em alta velocidade como vertedouros, tubos de sucção e canais.

Nas águas em velocidade, bolhas de vapor formam-se quando a pressão absoluta local em um dado ponto é reduzida a pressão de vapor ambiente correspondente a temperatura ambiente. Como as bolhas de vapor se movimentam no sentido descendente, com a água entrando em uma região de pressão mais alta, elas colapsam com grande impacto, pois apesar da pressão negativa estar limitada a até 10 
m.c.a (metros por coluna d'água), a superficie de cada bolha que se choca com o concreto é muito pequena, causando grande esforço de arrancamento.

\subsubsection{2 - Deterioração devida à fissuração}

$\mathrm{O}$ aparecimento de fissuras em uma superficie de concreto provoca o aumento de sua permeabilidade, que por sua vez dá origem a um ou mais processos de deterioração química. Os efeitos dessa deterioração química são físicos, porque há o enfraquecimento da pasta de cimento endurecido e a conseqüente vulnerabilidade do concreto, por exemplo, à abrasão e a erosão.

Quanto as causas fisicas para o aparecimento de fissuras é a exposição à temperaturas extremas, ou seja, à ação de gelo-degelo e do fogo. As demais causas serão abordadas mais detalhadamente no Capítulo 3 ao se tratar de fissuras no item Sintomatologia.

Em climas frios ou em obras para fins frigoríficos, a deterioração de pavimentos, muros de contenção, pontes, tem como uma das principais causas, a ação dos ciclos de gelo-degelo. A ação destes ciclos sobre o concreto pode ocorrer de várias formas.

A mais comum é a expansão progressiva da matriz da pasta de cimento, onde POWERS (1958) elucida que a água a baixas temperaturas começa a se congelar na cavidade capilar provocando aumento de volume desse capilar e consequentemente uma dilatação nessa cavidade da ordem de $9 \%$ ou então a expulsão do excesso de água para fora do corpo, ou ambos os efeitos.

Durante esse processo, uma pressão hidráulica é gerada e sua magnitude depende da distância até a parte exterior que permite a fuga, da permeabilidade e da velocidade de formação de gelo que formará então possíveis fissuras.

$\mathrm{O}$ concreto, quando submetido à ação do fogo, apresenta perda mais lenta de resistência até aproximadamente $400{ }^{\circ} \mathrm{C}$, caindo depois mais rapidamente à medida que a temperatura se torna mais elevada. Com temperatura em torno de $800{ }^{\circ} \mathrm{C}$, a resistência à compressão do concreto fica reduzida a cerca de $25 \%$ do seu valor original.

A Figura 11 ilustra esse comportamento do concreto. 


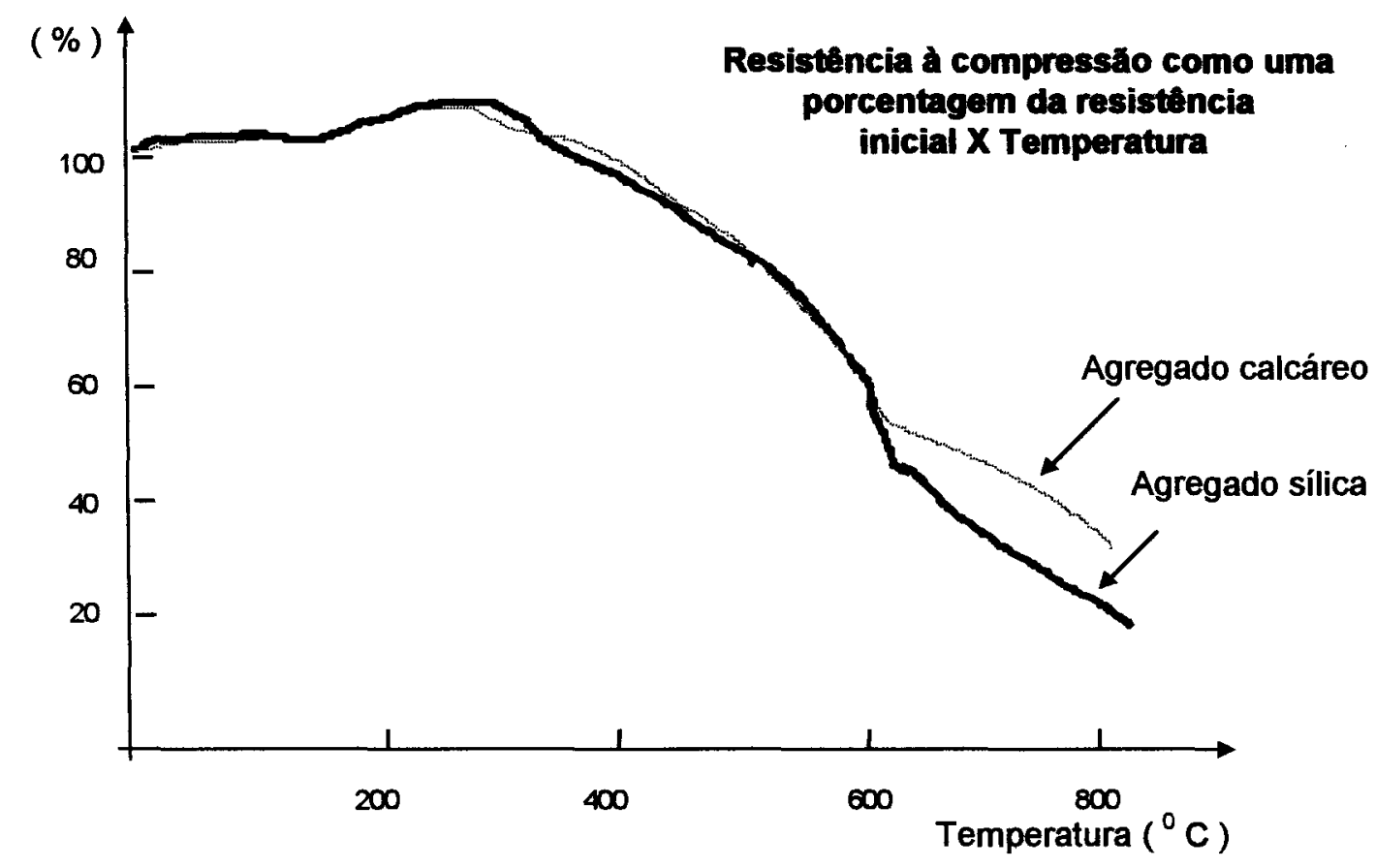

FIGURA 11 - A influência da temperatura e do tipo de agregado sobre a resistência a compressão do concreto (Fonte: LEITE \& SAAD, 1992).

\subsection{2 - DETERIORAÇÃo DO CONCRETO POR REAÇÕES}

\section{QUÍMICAS}

$O$ ataque químico consiste numa troca de massa entre o concreto e o meio ambiente, o que resulta eventualmente na modificação de certas propriedades do concreto.

Para METHA \& MONTEIRO (1994), a deterioração do concreto por reações químicas, envolve geralmente interações químicas entre agentes agressivos no meio externo e os constituintes da pasta de cimento. Porém existem exceções como as reações álcali-agregados, a hidratação retardada do $\mathrm{CaO}$ e $\mathrm{MgO}$ e a reação eletroquímica. Salientam ainda que qualquer meio externo com $\mathrm{pH}<12,5$ pode ser classificado como agressivo, já que em uma pasta de cimento Portland, a fase sólida se encontra em equilibrio estável com um fluido que apresente $\mathrm{pH}$ entre 12,5 e 13,5.

Dentre as reações químicas que envolvem a pasta de cimento endurecida destacam-se: 
a) as reações envolvendo hidrólise causando a lixiviação do hidróxido de cálcio $\mathrm{Ca}(\mathrm{OH})_{2}$ e expondo os outros componentes cimentíceos a possíveis ataques químicos;

b) reações por troca de cátions que podem causar três tipos de reações deletérias. Dentro dessas reações são destacadas as que formam sais solúveis como o cloreto de cálcio, acetato de cálcio, cloreto de alumínio, cloreto de ferro e com maior destaque os ácidos carbônico e o sulfúrico.

Ainda podem ser formados sais de cálcio insolúveis e não expansivos (ácido oxálico, tartárico e fluorídrico) e o ataque químico por soluções contendo sais de magnésio (cloreto, sulfato ou bicarbonato de magnésio) que ao interagirem com o silicato de cálcio hidratado (C-S-H), transformam-se em silicato de magnésio hidratado (Mg-S-H) que não possui característica cimentícea.

c) reações formando produtos expansivos fazendo com que ocorram tensões internas que se manifestam pelo fechamento de juntas de expansão, deformações e deslocamentos seguidos de fissuração, lascamento e pipocamento da estrutura.

São associados com as reações químicas expansivas no concreto quatro fenômenos: ataque por sulfato, ataque álcalis-agregado, hidratação retardada de $\mathrm{CaO}$ e $\mathrm{MgO}$ livres e corrosão da armadura no concreto.

\subsection{2.c.1 Ataque por sulfatos}

BRANDÃO (1998) relata que os sulfatos podem ser encontrados em solos (ex.: argilas), dissolvidos em água de lençol freático, em aterros contendo resíduos industriais (ex.: escória) e também na água do mar. $\mathrm{O}$ ataque por sulfatos contidos na água do mar é menos severo do que por sulfatos dissolvidos em água freática, devido à presença de cloretos que amenizam os efeitos das reações pois este tem uma tendência de formar inicialmente um cloro-aluminato, conhecido por Sal de Fridell, de modo que o comportamento expansivo associado à formação de sulfo-aluminato fica inibido. 
$\mathrm{O}$ ataque se dá pelas reações dos sulfatos com o hidróxido de cálcio livre $\left(\mathrm{Ca}(\mathrm{OH})_{2}\right)$ e com os aluminatos de cálcio hidratados $\left(3 \mathrm{CaO} . \mathrm{Al}_{2} \mathrm{O}_{3} \cdot 12 \mathrm{H}_{2} \mathrm{O}\right.$ ou, simplesmente, $\mathrm{C}_{3} \mathrm{~A}$ ), resultantes da hidratação do cimento. Os produtos dessas reações, respectivamente, o gesso $\left(\mathrm{CaSO}_{4} \cdot 2 \mathrm{H}_{2} \mathrm{O}\right)$ e o sulfo-aluminato de cálcio conhecido como etringita ou $\mathrm{Sal}$ de Candlot $\left(3 \mathrm{CaO} . \mathrm{Al}_{2} \mathrm{O}_{3} \cdot \mathrm{CaSO}_{4} \cdot 31 \mathrm{H}_{2} \mathrm{O}\right)$, cristalizam-se com a água num processo acompanhado por aumento de volume. Esta expansão é seguida de fissuração progressiva de configuração irregular, facilitando o acesso a novas soluções de sulfato. Pode ocorrer, também, desprendimento de lascas. $\mathrm{O}$ concreto adquire uma aparência esbranquiçada característica.

\subsection{2.c.2 Reação álcalis-agregado}

KIHARA et al. (1998) explicam que a reação álcalis-agregado (RAA) é um processo químico onde alguns constituintes mineralógicos do agregado reagem com os hidróxidos alcalinos (provenientes do cimento, água de amassamento, agregados, pozolanas, agentes externos, etc.) que estão dissolvidos na solução dos poros do concreto. Como produto da reação forma-se um gel hidroscópico expansivo. A manifestação da reação álcalis-agregado pode se dar de várias formas, desde expansões, movimentações diferenciais nas estruturas e fissurações até pipocamentos, exsudação do gel de e redução das resistências à tração e compressão.

O tipo de fissura provocada por este tipo de reação, atingem a superficie externa de forma irregular sendo referidas como fissuras mapeadas.

Atualmente são distinguidos três tipos deletérios da reação:

- reação álcali-sílica que envolve a presença de sílica amorfa ou certos tipos de vidros naturais (vulcânicos) e artificiais;

- reação álcali-silicato que é da mesma natureza da reação álcali-sílica porém, o processo ocorre mais lentamente, envolvendo alguns silicatos presentes nos feldspatos, folhelhos, argilosos, certas rochas sedimentares (como as grauvacas), metamórficas (como os quartzitos), e magmáticas (como os granitos) e, fundamentalmente, a presença de quartzo deformado (tensionado) e minerais expansivos; 
- reação álcali-carbonato que ocorre entre certos calcários dolomíticos e as soluções alcalinas presentes nos poros do concreto.

METHA \& MONTEIRO (1994) relatam que a reação álcali-sílica é pelo menos uma das causas de deterioração de estruturas localizadas em ambientes úmidos como: barragens, estacas de pontes e estruturas marinhas.

\subsection{2.c.3 Hidratação do $\mathrm{MgO}$ e $\mathrm{CaO}$ cristalinos}

METHA \& MONTEIRO (1994), mostram que quando $\mathrm{MgO}$ e $\mathrm{CaO}$ (calcinado) cristalinos estão presentes em quantidades consideráveis no cimento Portland e são hidratados, estes podem causar expansão e fissuração no concreto.

Atualmente o fenômeno de expansão devido à presença do $\mathrm{CaO}$ cristalinos em cimentos Portland é raro de acontecer, pois os avanços incorporados no controle da manufatura asseguram que o conteúdo de $\mathrm{CaO}$ não combinado ou cristalino não exceda à $1 \%$ (acima de $2,8 \%$ apresenta expansão considerável).

\subsection{2.c.4 Corrosão da armadura do concreto}

HELENE (1986) ressalta que o fenômeno da corrosão de armaduras é mais freqüente do que qualquer outro fenômeno de degradação das estruturas de concreto armado, havendo assim um comprometimento tanto do ponto de vista estético como da segurança, sendo sempre oneroso o seu reparo ou recuperação.

Segundo METHA \& MONTEIRO (1994), o dano ao concreto resultante da corrosão da armadura se manifesta na forma de expansão, fissuração e finalmente o lascamento do cobrimento. Além da perda de cobrimento pode ocorrer perda de aderência entre o concreto e o aço e a diminuição da área da seção transversal da armadura ocasionando até o colapso da estrutura.

De acordo com HELENE (1986) o processo de corrosão da armadura está fundamentado nos princípios de corrosão eletroquímica sendo que ela só ocorre nas seguintes condições :

- deve existir um eletrólito; 
- deve existir uma diferença de potencial;

- deve existir oxigênio; $e$

- pode existir agentes agressivos.

A formação de uma célula de corrosão ou pilha pode ocorrer como indicado na Figura 12 que explica graficamente o fenômeno. Como em qualquer outra célula, há um ânodo, um cátodo, um condutor metálico e um eletrólito. Qualquer diferença de potencial entre as zonas catódicas e anódicas acarreta o aparecimento de corrente elétrica. Dependendo da magnitude dessa corrente e do acesso de oxigênio, poderá ou não haver corrosão.

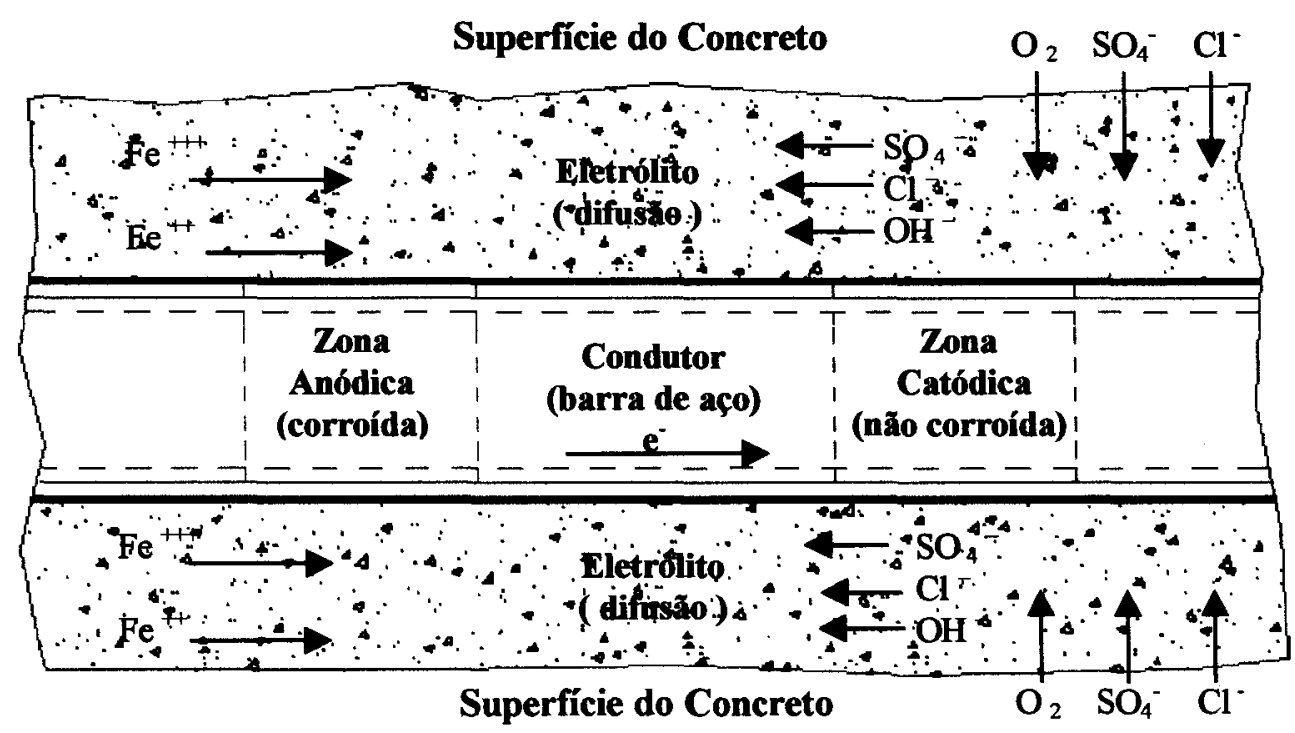

\section{FIGURA 12 - Célula de corrosão (fonte - HELENE, 1986)}

\section{- Deve existir um eletrólito :}

VOGEL (1981) define que solução é um produto homogêneo obtido quando se dissolve uma substância em um solvente (água). Quando essas substâncias são ácidos, bases e sais, por exemplo, elas passam corrente elétrica através de suas soluções. Essas substâncias são denominadas eletrólitos.

A água quimicamente pura não conduz eletricidade; se no entanto, nela forem dissolvidos ácidos, bases ou sais, a solução resultante não só conduzirá a corrente elétrica, como também ocorrerão transformações químicas. 
Em experiências realizadas com concretos com temperatura ambiente e variadas umidades relativas (U.R.), HELENE (1986) mediu as respectivas umidades de equilíbrio e constatou a presença de água nesses concretos. Sendo assim, pode-se afirmar que sempre há água no concreto e portanto, sempre se estabelecerá a existência de eletrólitos no que depender dela.

\section{- Deve existir uma diferença de potencial:}

Quando se submerge o aço a uma solução, parte dos átomos de ferro tende a passar a mesma, transformando-se em cátions ferro $\left(\mathrm{Fe}^{++}\right)$, com carga elétrica positiva, deixando a armadura com carga negativa e criando-se o que se conhece como potencial de equilíbrio ou reversível. Este fato, por si só, não gera força eletromotriz, mas em presença de reagentes capazes de sofrer redução, ou seja, capazes de combinar com o elétron liberado na reação de formação do íon ferroso, pode formar-se uma pilha ou célula de corrosão eletroquímica.

Qualquer diferença de potencial que se produza entre dois pontos da barra, por diferença de umidade, aeração, concentração salina, tensão no concreto e no aço, é capaz de desencadear pilhas conectadas em série.

\section{- Deve existir oxigênio:}

É necessário que haja oxigênio para a formação de ferrugem, além do eletrólito representado pela umidade e o hidróxido de cálcio, sem o que não é possível a seguinte reação:

$$
4 \mathrm{Fe}+3 \mathrm{O}_{2}+6 \mathrm{H}_{2} \mathrm{O} \rightarrow 4 \mathrm{Fe}(\mathrm{OH})_{3}
$$

(ferrugem)

$\mathrm{Na}$ realidade, as reações são mais complexas, e o produto de corrosão, denominado ferrugem, nem sempre é o $\mathrm{Fe}(\mathrm{OH})_{3}$, mas sim uma gama de óxidos e hidróxidos de ferro resultantes das seguintes etapas de corrosão :

- nas zonas anódicas, o ferro perde elétrons, ocasionando a dissolução do metal:

$$
2 \mathrm{Fe} \rightarrow 2 \mathrm{Fe}^{++}+4 \mathrm{e}^{-}
$$

(oxidação)

- nas zonas catódicas, em meios neutros e aerados, ocorre :

$$
2 \mathrm{H}_{2} \mathrm{O}+\mathrm{O}_{2}+4 \mathrm{e}^{-} \rightarrow 4 \mathrm{OH}^{-}
$$

$$
\text { (redução) }
$$

- acarretando as seguintes reações de corrosão com a formação de ferrugem : 


$$
\begin{aligned}
& 2 \mathrm{Fe}+2 \mathrm{H}_{2} \mathrm{O}+\mathrm{O}_{2} \rightarrow 2 \mathrm{Fe}^{++}+4 \mathrm{OH}^{\circ} \\
& 2 \mathrm{Fe}^{++}+4 \mathrm{OH} \rightarrow 2 \mathrm{Fe}(\mathrm{OH})_{2} \\
& \text { ou } \mathrm{FeO} . \mathrm{O} \\
& 2 \mathrm{Fe}(\mathrm{OH})_{2}+\mathrm{H}_{2} \mathrm{O}+1 / 2 \mathrm{O}_{2} \rightarrow 2 \mathrm{Fe}(\mathrm{OH})_{3} \\
& \text { ou } \mathrm{FeO}_{3} . \mathrm{H}_{2} \mathrm{O}
\end{aligned}
$$

A transformação do aço metálico em ferrugem é segundo METHA \& MONTEIRO (1994) acompanhada de um aumento de volume de até $600 \%$ do metal original. Acredita-se que este aumento de volume seja a causa principal de expansão e fissuração do concreto.

\section{- Podem existir agentes agressivos}

A corrosão pode ser acelerada por agentes agressivos contidos ou absorvidos pelo concreto. A presença destes assumem o papel de substância que ao ser dissolvida no solvente água contido no concreto, possibilita a geração do eletrólitos que, conjuntamente com o oxigênio e a diferença de potencial, desencadeiam o processo de uma célula (pilha) de corrosão eletroquímica.

Entre eles pode-se citar os íons sulfetos $\left(\mathrm{S}^{-}\right)$, os íons cloretos $\left(\mathrm{Cl}^{-}\right)$, o dióxido de carbono $\left(\mathrm{CO}_{2}\right)$, os nitritos $\left(\mathrm{NO}_{3}^{-}\right)$, o gás sulfidrico $\left(\mathrm{H}_{2} \mathrm{~S}\right)$, o cátion amônio $\left(\mathrm{NH}_{4}{ }^{+}\right)$, os óxidos de enxofre $\left(\mathrm{SO}_{2}, \mathrm{SO}_{3}\right)$, fuligem etc.

\section{6 - PRINCIPAIS MECANISMOS DE DETERIORAÇÃO E ENVELHECIMENTO DAS ESTRUTURAS DE CONCRETO}

Segundo DINIZ (1998) os mecanismos mais importantes e freqüentes de envelhecimento e deterioração das estruturas de concreto dividem-se em mecanismos preponderantes de deterioração relativos ao concreto e mecanismos preponderantes de deterioração relativos às armaduras.

Além dos mecanismos de deterioração do concreto e da armadura já descritos no item 2.5, OLIVEIRA \& HELENE (1991) acrescentam a retração, retenção de fuligem e fungos e concentração salina e HELENE (1998) considera também os 
chamados mecanismos de deterioração propriamente dito todos aqueles relacionados às ações mecânicas, movimentações de origem térmica, impactos, ações cíclicas (fadiga), deformação lenta (fluência), relaxação e outros considerados em qualquer norma ou código regional, nacional ou internacional.

A retenção de fuligem e fungos é mencionada a seguir. A concentração salina será abordada no item que elucidará sobre atmosfera marinha e água do mar. Os demais mecanismos citados acima serão melhor elucidados no Capítulo 3 quando forem abordadas as sintomatologias nas estruturas de concreto.

\subsection{1 - RETENÇÃO DE FULIGEM E FUNGOS}

As bases úmidas são atacadas freqüentemente por microorganismos de ordem botânica ou animal. Trata-se de bactérias, fungos, moluscos e algas, que têm um ativo metabolismo. As superficies atacadas são mantidas permanentemente úmidas, acelerando a maioria dos mecanismos de degradação, além de comprometerem a salubridade de ambientes internos.

É também na porosidade superficial do concreto que se deposita a fuligem dos centros urbanos e industriais. Tratam-se de partículas de natureza ácida que, num primeiro momento, fixam-se nos poros do concreto. A seguir, devido a elevada superficie específica, passam a reter água e novas partículas, num processo cíclico progressivo.

Como resultado dessa deposição superficial, tem-se a redução da alcalinidade do concreto e a conseqüente degradação e risco de despassivação da armadura.

Resumindo, apresentam-se na Tabela 02 de forma sucinta, as principais formas de degradação das superficies de concreto. 
TABELA 02 - Mecanismos de degradação das superfícies de concreto (fonte OLIVEIRA \& HELENE, 1991)

\begin{tabular}{|c|c|c|c|}
\hline \multicolumn{2}{|c|}{ AGRESSIVIDADE } & \multicolumn{2}{|c|}{$\begin{array}{l}\text { CONSEQUÊNCIAS INERENTES AO } \\
\text { PROCESSO }\end{array}$} \\
\hline $\begin{array}{l}\text { Natureza do } \\
\text { processo }\end{array}$ & Condições particulares & $\begin{array}{c}\text { Alterações de cor } / \\
\text { manchas }\end{array}$ & $\begin{array}{c}\text { Alterações físico- } \\
\text { químicas }\end{array}$ \\
\hline Carbonatação & U.R. $60 \%$ a $85 \%$ & Em geral mais clara & $\begin{array}{l}\text { - redução do pH } \\
\text { - corrosão das } \\
\text { armaduras } \\
\text { - fissuração } \\
\text { superficial }\end{array}$ \\
\hline Lixiviação & $\begin{array}{c}\text { Atmosfera ácida e águas } \\
\text { moles }\end{array}$ & $\begin{array}{l}\text { Escurece com } \\
\text { manchas }\end{array}$ & $\begin{array}{l}\text { - redução do pH } \\
\text { - corrosão das } \\
\text { armaduras } \\
\text { - desagregação } \\
\text { superficial }\end{array}$ \\
\hline Retração & $\begin{array}{l}\text { Molhagem/secagem } \\
\text { Ausência de cura }\end{array}$ & Manchas e fissuras & $\begin{array}{l}\text { - fissuração } \\
\text { - redução do pH } \\
\text { - corrosão das } \\
\text { armaduras }\end{array}$ \\
\hline Fuligem & $\begin{array}{l}\text { Atmosferas urbanas e } \\
\text { industriais }\end{array}$ & Manchas escuras & $\begin{array}{l}\text { - redução do pH } \\
\text { - corrosão das } \\
\text { armaduras }\end{array}$ \\
\hline Fungos & Zonas úmidas e salinas & $\begin{array}{l}\text { Manchas escuras } \\
\text { esverdeadas }\end{array}$ & $\begin{array}{l}\text { - redução do pH } \\
\text { - corrosão das } \\
\text { armaduras } \\
\text { - desagregação } \\
\text { superficial }\end{array}$ \\
\hline $\begin{array}{l}\text { Concentração } \\
\text { salina }\end{array}$ & $\begin{array}{l}\text { Atmosferas salinas e } \\
\text { industriais }\end{array}$ & Esbranquecimento & $\begin{array}{c}\text { - redução do pH } \\
\text {-despassivação } \\
\text { das armaduras } \\
\text { - desagregação } \\
\text { superficial }\end{array}$ \\
\hline
\end{tabular}




\section{7 - A INFLUÊNCIA DO MEIO AMBIENTE NA DURABILIDADE E PRINCIPAIS MEIOS AGRESSIVOS NO CONCRETO}

Quando se estuda as possiveis formas de deterioração do concreto, é importante salientar que além dos processos químicos e fisicos apresentados, existem outros fatores que podem agir diretamente e de maneira deletéria no concreto.

Dentro desses parâmetros é de suma importância a consideração e o estudo do meio ambiente e os agentes agressivos encontrados nesse ao qual a estrutura é inserida. Para isso são abordadas a seguir a classificação dos diferentes tipos de atmosferas existentes e os agentes agressivos que podem interferir no concreto.

\section{- Atmosfera rural}

Considera-se as regiões ao ar livre, a grande distância das fontes poluidoras pois tal atmosfera apresenta fraca ação agressiva a menos que haja uma fonte natural de gás ou sólido, como esterco e extrume que liberam $\mathrm{NH}_{3}$ e $\mathrm{SO}_{2}$ na fermentação, os gases encontrados são praticamente desprezíveis.

O processo de carbonatação torna-se mais lento também que em outras regiões.

A chuva em regiões rurais (pequenas cidades sem indústrias) tem $\mathrm{pH}$ "natural", da ordem de 6,5.

\section{- Atmosfera urbana}

Considera-se regiões ao ar livre, dentro de centros populacionais maiores. Essas atmosferas, em geral, contém impurezas em forma de óxidos de enxofre $\left(\mathrm{SO}_{2}\right)$, fuligem ácida e outros agentes agressivos, tais como $\mathrm{CO}_{2}, \mathrm{No}_{\mathrm{x}}\left(\mathrm{NO}+\mathrm{NO}_{2}\right), \mathrm{H}_{2} \mathrm{~S}$, $\mathrm{SO}_{4}{ }^{-*}$, etc. 
Um fator relevante na consideração das diferentes atmosferas é a umidade relativa do $a^{1}$ pois ela afeta a velocidade da corrosão atmosférica. Porém, a simples presença da água no ar não causa corrosão; ar puro, saturado e com vapor d'água determina uma corrosão muito leve em metais como ferro e cobre. Quando a umidade relativa está entre $65 \%$ e $85 \%$, em temperatura ambiente, conhecida também como umidade crítica do aço, este começa a corroer de maneira apreciável.

Assim, construções em zonas urbanas consideradas úmidas $(80 \%<$ U.R $<$ $90 \%$ ) são mais vulneráveis ao processo de corrosão.

Nessa atmosfera também é comum a presença de $\mathrm{SO}_{2}$ e $\mathrm{H}_{2} \mathrm{~S}$ no ar originados pela queima de combustíveis contendo enxofre ou respectivamente da ação bacteriológica de rios e empresas.

$\mathrm{O} \mathrm{pH}$ da água de chuva de centros urbanos e industriais pode ser de 3,5 a 4,0, ou seja, fortemente ácida.

\section{- Atmosfera marinha e água do mar}

Considera-se as regiões ao ar livre, sobre o mar e perto da costa que contêm cloretos de sódio e de magnésio, quer em forma de cristais, quer em forma de gotículas de água salgada, conhecida também como névoa salina.

A velocidade de corrosão em atmosfera marinha pode ser da ordem de 30 a 40 vezes superior à que ocorre em atmosfera rural.

A água do mar contém, entre outras substâncias agressivas ao concreto, sais de magnésio, sódio e potássio. A princípio ela poderia ser classificada como fortemente agressiva devido aos altos teores de magnésio e sulfato que apresenta.

No entanto, a corrosão sulfática provocada pơr essa água é mais lenta que em águas doces com iguais teores de sulfatos pois existe a ação inibidora do cloreto de sódio como explicado no item de 2.5.2.c.1.

\footnotetext{
${ }^{1}$ Umidade relativa do ar - Relação entre o valor de conteúdo de vapor de água na atmosfera e o valor de saturação para uma dada temperatura.
} 
Os cloretos têm ação mais profunda e danosa. Por estarem dissolvidos na água, penetram na estrutura porosa do concreto através de capilaridade, higroscopicidade ou permeabilidade. Quando da evaporação da água precipitam no interior. Processos de molhagem e secagem vão aumentando a concentração de sais no concreto, até teores que podem despassivar a armadura, promovendo sua corrosão.

A corrosão por cloretos é bem caracterizada pela presença de profundas cavidades, em pontos localizados.

\section{- Atmosfera industrial}

Considera-se as regiões ao ar livre em zonas industriais contaminadas por gases e cinzas, sendo mais agressivos e freqüentes o $\mathrm{H}_{2} \mathrm{~S}, \mathrm{No}_{\mathrm{x}}\left(\mathrm{NO}+\mathrm{NO}_{2}\right)$, e o $\mathrm{SO}_{2}$ pode este último oxidar-se e gerar $\mathrm{H}_{2} \mathrm{SO}_{4}$.

Atmosferas industriais podem aceleram de 60 a 80 vezes mais o processo de corrosão, quando comparados com a atmosfera rural.

Entretanto, a ação danosa dessa atmosfera sempre deve estar associada à umidade relativa da região, pois se ela não atingir a crítica para o aço não haverá risco de corrosão acentuada.

Pode-se concluir com esse fato que as exigências com a espessura de cobrimento do concreto devem ser diferenciadas de acordo com as umidades relativas das regiões em que as estruturas de concreto estiverem submetidas.

Além da U.R., a temperatura também é um fator relevante pois para um dado teor de vapor de água no ar, uma diminuição brusca da temperatura pode acarretar condensação ou, pelo menos, aumentar a U.R., podendo então ultrapassar a umidade crítica. 


\section{- Micro-clima (atmosfera viciada)}

Considera-se as regiões em locais fechados com baixa taxa de renovação de ar.

O exemplo mais significativo é a ação do ácido sulfúrico, gerado em coletores e interceptores de esgoto.

Alguns edificios industriais que abrigam certos processos químicos também podem ser considerados como atmosferas viciadas. Os teores de $\mathrm{SO}_{2}, \mathrm{NH}_{3}$ e $\mathrm{H}_{2} \mathrm{~S}$ podem ser em mais de 100 vezes superiores aos encontrados na atmosfera ao ar livre da comunidade vizinha à industria. Nesses casos, tais como fábricas de papel e celulose, processamento de rayon, fertilizantes, queima de óleo combustível para fornos, os cuidados na prevenção da deterioração do concreto devem ser intensificados.

\section{- Águas puras}

São águas que não contêm substâncias dissolvidas ou as contêm em quantidades desprezíveis. Quanto mais pura uma água, maior o seu poder ou capacidade dissolvente.

Água pura é também sinônimo de água mole (ex: água potável), ou seja, quanto menos dura - menos carbonato de cálcio e magnésio ela contenha - maior seu poder dissolvente. Admite-se que toda água com mais de $150 \mathrm{mg} / \mathrm{l}=0,0015 \%$ de sólidos (resíduos) dissolvidos (não evaporáveis) é agressiva ao concreto.

\section{- Águas de regiōes pantanosas ricas em húmus}

Tanto as águas subterrâneas como as superficiais são agressivas ao concreto quando o teor de ácidos húmicos e outras substâncias agressivas atingem os valores limites indicados na Norma CETESB L1.007. Essas águas costumam conter também ácido carbônico livre e agressivo. Os ácidos orgânicos, em geral, atacam menos intensamente o concreto que os ácidos inorgânicos e minerais. 


\section{- Águas residuais ácidas}

Todas as águas de origem doméstica e, principalmente, as industriais, são potencialmente agressivas ao concreto. Em especial, as águas de indústrias que utilizam coque, indústrias de papel e celulose, indústrias de álcool e açúcar, curtume, tinturarias, galvanosplatia e laticínios.

\section{- Graxas e óleos}

As graxas e óleos vegetais e seus ácidos graxos são prejudiciais ao concreto porque reagem com a cal (portlandita) do cimento e formam sabões cálcicos.

Os óleos e graxas minerais só atacam o concreto quando contêm ácidos livres, enquanto que os de origem vegetal e animal podem degradar-se com o tempo gerando ou formando ácidos orgânicos. De qualquer forma o ataque é lento. A maior preocupação deve ser com a queda da resistência mecânica do concreto, que pode atingir valores superiores a $20 \%$ e com a queda de aderência concreto/armadura.

\section{- Outras substâncias agressivas}

Além dos meios agressivos mais comuns citados anteriormente, existe uma série de substâncias que podem deteriorar o concreto. As situações mais comuns podem ser encontradas em estruturas destinadas a armazenamento de certos produtos, tais como: vinho, ácido, sucos de frutas, cereais, adubos e outros podendo desencadear as reações deletérias por formação de sais solúveis.

\section{8 - CLASSIFICAÇÃO DA AGRESSIVIDADE DO MEIO AMBIENTE}

Segundo DINIZ (1998) nos projetos das estruturas correntes, a agressividade ambiental pode ser classificada, de forma conceitual de acordo com a Tabela 03 . 
TABELA 03 - Classes de agressividade ambiental (DINIZ,1998).

\begin{tabular}{ccc}
\hline Classe de agressividade & Agressividade & $\begin{array}{c}\text { Risco de deterioração da } \\
\text { estrutura }\end{array}$ \\
\hline I & Fraca & Insignificante \\
\hline II & Média & pequeno \\
\hline III & Forte & grande \\
\hline IV & muito forte & elevado \\
\hline
\end{tabular}

A classificação da agressividade do meio ambiente às estruturas de concreto armado e protendido, pode também ser avaliada de modo simplificado de acordo com as condições de exposição da estrutura ou de suas partes como é visto a seguir na Tabela 04.

TABELA 04 - Classes de agressividade do ambiente em função das condições de exposição (DINIZ, 1998).

\begin{tabular}{|c|c|c|c|c|}
\hline \multirow{3}{*}{ Macro clima } & \multicolumn{4}{|c|}{ micro-clima } \\
\hline & \multicolumn{2}{|c|}{ Interior das edificações } & \multicolumn{2}{|c|}{ exterior das edificações } \\
\hline & $\begin{array}{c}\text { Seco* } \\
\text { UR } \leq 65 \%\end{array}$ & $\begin{array}{l}\text { Úmido ou ciclos }{ }^{\star \star} \\
\text { de molhagem e } \\
\text { secagem }\end{array}$ & $\begin{array}{c}\text { Seco*t* } \\
\text { UR } \leq 65 \%\end{array}$ & $\begin{array}{l}\text { úmido ou ciclos } \\
\text { de molhagem e } \\
\text { secagem }\end{array}$ \\
\hline Rural & 1 & 1 & 1 & II \\
\hline Urbana & $\mathrm{T}$ & II & $\mathrm{T}$ & II \\
\hline Marinha & II & III & -- & III \\
\hline Industrial & II & III & II & III \\
\hline Específico & II & III ou IV & III & III ou IV \\
\hline $\begin{array}{l}\text { Respingos } \\
\text { de maré }\end{array}$ & -- & - & - & IV \\
\hline $\begin{array}{c}\text { Submersa } \\
\geq 3 m\end{array}$ & -- & - & -- & 1 \\
\hline Solo & -- & -- & $\begin{array}{c}\text { Não } \\
\text { agressivo }\end{array}$ & $\begin{array}{c}\text { Úmido e agressivo } \\
\text { II, III ou IV }\end{array}$ \\
\hline
\end{tabular}

Notas: ${ }^{*}$ - salas, dormitórios ou ambientes com concreto revestido com argamassa e pintura. 
** - vestiários, banheiros, cozinhas, garagens, lavanderias.

*** - obras no interior do nordeste do país, partes protegidas de chuva em ambientes predominantemente secos.

**** - ambientes quimicamente agressivos, tanques industriais, galvanoplastia, branqueamento em indústrias de celulose e papel, armazéns de fertilizantes, indústrias químicas.

Existem duas maneiras conhecidas de classificar a agressividade do meio ambiente: forma indireta e a forma rigorosa. Entretanto a forma usualmente empregada para classificar um meio é a forma rigorosa que dada em função da concentração efetiva de compostos agressivos presentes. Contudo ela pressupõe uma análise fisico-química adequada do meio, que torna-a muito complexa e exige metodologia adequada.

No Brasil dispõe-se da Norma CETESB L1.007 - "Agressividade do Meio ao Concreto Classificação". Porém, usualmente são seguidas as determinações específicas propostas pelo CEB/FIP Model Code 1990, apresentados na Tabela 05.

TABELA 05 - Classificação da agressividade ambiental visando a durabilidade do concreto (HELENE, 1998).

\begin{tabular}{ccccc}
\hline Classe de agressividade & $\mathrm{I}$ & $\mathrm{II}$ & $\mathrm{III}$ & IV \\
\hline $\mathrm{pH}$ & $>6,0$ & $5,9-5,0$ & $4,9-4,5$ & $<4,5$ \\
\hline $\mathrm{CO}_{2}$ agressivo $\mathrm{mg} / \mathrm{L}$ & $<20$ & $20-30$ & $30-100$ & $>100$ \\
\hline Amônia $\left(\mathrm{NH}_{4}{ }^{+}\right) \mathrm{mg} / \mathrm{L}$ & $<100$ & $100-150$ & $150-250$ & $>250$ \\
\hline Magnésia $\left(\mathrm{Mg}^{2+}\right) \mathrm{mg} / \mathrm{L}$ & $<150$ & $150-250$ & $250-500$ & $>500$ \\
\hline Sulfato $\left(\mathrm{SO}_{4}{ }^{2-}\right) \mathrm{mg} / \mathrm{L}$ & $<400$ & $400-700$ & $700-1500$ & $>1500$ \\
\hline Sólidos dissolvidos $\mathrm{mg} / \mathrm{L}$ & $>150$ & $150-50$ & $<50$ & $<50$ \\
\hline
\end{tabular}

Notas: 1. - No caso de solos a análise deve ser feita no extrato aquoso do solo;

2. - Água em movimento, temperatura acima de $30{ }^{\circ} \mathrm{C}$, ou solo agressivo muito permeável conduz a um aumento de um grau na classe de agressividade.

3. - Ação fisica superficial tal como abrasão e cavitação aumentam a velocidade de ataque químico. 


\section{9 - CLASSIFICAÇÃO DOS CONCRETOS}

Conforme HELENE (1998) a resistência do concreto aos diferentes meios agressivos depende da natureza e do tipo de seus materiais constituintes assim como a composição ou dosagem do concreto, dependendo portanto do tipo e consumo de cimento, tipo e consumo de adições, relação água/cimento e natureza e diâmetro máximo do agregado.

$\mathrm{O}$ autor menciona ainda que, através da literatura técnica, encontra-se uma diretriz onde ressalta que a durabilidade da estrutura de concreto é determinada por quatro fatores chamados como regra dos $4 \mathrm{C}$ :

Composição ou traço do concreto;

Compactação ou adensamento efetivo do concreto na estrutura;

Cura efetiva do concreto na estrutura;

Cobrimento das armaduras.

O autor orienta que pela ausência de valores obtidos por ensaios experimentais realizados com os concretos realmente empregados nas obras, pode-se adotar as Tabelas 06 e 07 como uma orientação referentes à corrosão de armaduras e a deterioração do concreto. 
TABELA 06 - Classificação da resistência dos concretos frente ao risco de corrosão de armaduras (HELENE, 1998).

\begin{tabular}{|c|c|c|c|c|}
\hline $\begin{array}{l}\text { Classe de } \\
\text { concreto }\end{array}$ & $\begin{array}{l}\text { Classe de } \\
\text { resistência }\end{array}$ & $\begin{array}{c}\text { Máxima } \\
\text { relação a/c }\end{array}$ & $\begin{array}{c}\text { Deterioração por } \\
\text { carbonatação }\end{array}$ & $\begin{array}{c}\text { Deterioração por } \\
\text { Cloretos }\end{array}$ \\
\hline & (NBR 8953) & & Teor de adições & Teor de adições \\
\hline Durável & $\geq \mathrm{C} 50$ & $\leq 0,38$ & $\begin{array}{c}\leq 10 \% \text { de pozolana, } \\
\text { silica ativa ou escória de } \\
\text { alto forno }\end{array}$ & $\begin{array}{c}\geq 20 \% \text { de pozolana } \\
\text { ou sílica ativa } \\
\geq 65 \% \text { de escória de } \\
\text { alto forno }\end{array}$ \\
\hline Resistente & $\begin{array}{c}\mathrm{C} 35, \mathrm{C} 40 \\
\mathrm{C} 45\end{array}$ & $\leq 0,50$ & $\begin{array}{c}\leq 10 \% \text { de pozolana ou } \\
\text { sílica ativa } \\
\leq 15 \% \text { de escória de alto } \\
\text { forno }\end{array}$ & $\begin{array}{c}\geq 10 \% \text { de pozolana } \\
\text { ou sílica ativa } \\
\geq 35 \% \text { de escória de } \\
\text { alto forno }\end{array}$ \\
\hline Normal & $\mathrm{C} 25, \mathrm{C} 30$ & $\leq 0,62$ & qualquer & qualquer \\
\hline Efêmero & $\begin{array}{c}\text { C10, C15 } \\
\text { C20 }\end{array}$ & Qualquer & qualquer & qualquer \\
\hline
\end{tabular}

TABELA 07 - Classificação da resistência dos concretos frente ao risco de deterioração por lixiviação ou por formação de compostos expansivos (HELENE, 1998).

\begin{tabular}{|c|c|c|c|c|}
\hline \multirow{2}{*}{$\begin{array}{l}\text { Classe de } \\
\text { concreto }\end{array}$} & \multirow{2}{*}{$\begin{array}{c}\text { Classe de } \\
\text { resistência } \\
\text { (NBR 8953) }\end{array}$} & \multicolumn{2}{|c|}{ Deterioração por Expansão } & \multirow{2}{*}{$\begin{array}{c}\begin{array}{c}\text { Deterioração por } \\
\text { Lixiviação }\end{array} \\
\text { Teor de adições }\end{array}$} \\
\hline & & $\begin{array}{l}\text { Teor de } \mathrm{C}_{3} \mathrm{~A} \text { no } \\
\text { Cimento Anidro }\end{array}$ & Teor de adições & \\
\hline \multirow[t]{2}{*}{ Durável } & $\geq \mathrm{C} 50$ & $\leq 5 \%$ & $\begin{array}{c}\geq 20 \% \text { de pozolana } \\
\text { ou sílica ativa }\end{array}$ & $\begin{array}{c}\geq 20 \% \text { de pozolana } \\
\text { ou sílica ativa }\end{array}$ \\
\hline & & & $\begin{array}{c}\geq 65 \% \text { de escória de } \\
\text { alto forno }\end{array}$ & $\begin{array}{c}\geq 65 \% \text { de escória de } \\
\text { alto forno }\end{array}$ \\
\hline \multirow[t]{2}{*}{ Resistente } & $\begin{array}{l}\text { C35, C40, } \\
\quad \text { C45 }\end{array}$ & $\leq 5 \%$ & $\begin{array}{c}\geq 10 \% \text { de pozolana } \\
\text { ou sílica ativa }\end{array}$ & $\begin{array}{c}\geq 10 \% \text { de pozolana } \\
\text { ou sílica ativa }\end{array}$ \\
\hline & & & $\begin{array}{c}\geq 35 \% \text { de escória de } \\
\text { alto forno }\end{array}$ & $\begin{array}{c}\geq 35 \% \text { de escória de } \\
\text { alto fomo }\end{array}$ \\
\hline Normal & $\mathrm{C} 25, \mathrm{C} 30$ & $\leq 8 \%$ & qualquer & qualquer \\
\hline Efêmero & $\begin{array}{c}\text { C10, C15 } \\
\text { C20 }\end{array}$ & Qualquer & qualquer & qualquer \\
\hline
\end{tabular}


Uma vez que mantidas constantes as demais variáveis que entram em jogo na problemática da durabilidade das estruturas de concreto, pode-se fazer uma correlação entre agressividade do meio ambiente e durabilidade do concreto com a qualidade como HELENE (1998) e DINLZ (1998) mostram na Tabela 08 a seguir.

TABELA 08 - Correspondência entre agressividade do ambiente e durabilidade do concreto (HELENE, 1998) com qualidade do concreto (DINIZ, 1998).

\begin{tabular}{cccc}
\hline Classe de agressividade & $\begin{array}{c}\text { Concreto } \\
\text { recomendável }\end{array}$ & $\begin{array}{c}\text { Classe de } \\
\text { Concreto }\end{array}$ & $\begin{array}{c}\text { Relação A/C } \\
\text { (em massa) }\end{array}$ \\
\hline I- fraca & $\begin{array}{c}\text { Efêmero, normal, } \\
\text { resistente ou } \\
\text { durável }\end{array}$ & $\geq \mathrm{C} 20$ & $\leq 0,65$ \\
\hline II-média & $\begin{array}{c}\text { Normal, } \\
\text { resistente ou } \\
\text { durável }\end{array}$ & $\geq \mathrm{C} 25$ & $\leq 0,60$ \\
\hline III- forte & $\begin{array}{c}\text { Resistente ou } \\
\text { durável }\end{array}$ & $\geq \mathrm{C} 30$ & $\leq 0,55$ \\
\hline IV-muito forte & Durável & $\geq \mathrm{C} 40$ & $\leq 0,45$ \\
\hline
\end{tabular}

Vale ressaltar que essas recomendações acima servem como uma referência dada pelo autor. Porém é possível utilizar com segurança e sem comprometimento da durabilidade um concreto que não seja recomendável pela tabela acima desde que esse fato seja compensado com outras medidas protetoras e preventivas. 


\section{PATOLOGIA DAS ESTRUTURAS DE CONCRETO ARMADO}

\section{1 - A IMPORTÂNCIA DA PATOLOGIA NAS ESTRUTURAS DE} CONCRETO ARMADO

CANOVAS (1988) relata que a resistência e a durabilidade de uma estrutura, da mesma forma que a de um ser vivo, vai depender indiscutivelmente dos cuidados que se tenham com ela não apenas durante sua gestação ou projeto, mas também durante seu crescimento ou construção e, posteriormente, durante sua vida ou manutenção.

Para introduzir os conceitos de Patologia, o autor correlaciona continuamente a vida de uma obra à vida de um ser vivo, estabelecendo que uma construção sofre com as reações do meio ambiente bem como às ações mecânicas a que são submetidas. Esses fatores podem danificá-la da mesma forma que um ser humano adoece quando exposto à grandes variações nas condições ambientais, por exemplo.

E continua a analogia ao relacionar que da mesma forma que acontece com as pessoas, há estruturas sadias e estruturas enfermas. Estas últimas são as que tiveram um desenvolvimento pouco feliz, seja por defeitos de projeto ou por falta de cuidados e vigilância na sua execução ou durante sua conservação e manutenção.

Após detectar quais as possíveis causas que tenham podido motivar a enfermidade, trata-se de encontrar, de acordo com a enfermidade, qual a terapia mais adequada a ser empregada em cada caso, considerando que nem sempre será possível devolver a saúde ao enfermo, pois haverá lesões que, com um tratamento correto (reforço ou reparação), evoluirão favoravelmente, enquanto outras terão uma gravidade que não será possível mudar sua evolução, estando a estrutura condenada à demolição. 
Segundo LIBÓRIO (1994) a Patologia insere-se na Ciência Engenharia como a disciplina que estuda as origens, causas, mecanismos de ocorrência, manifestações e conseqüências das situações em que as construções, ou suas partes, não apresentem um desempenho mínimo preestabelecido.

Em geral, pode-se assegurar que as patologias produzidas em estruturas não decorrem de uma só causa, ou enfermidade, agindo isoladamente, mas uma combinação de várias delas. É freqüente encontrar estruturas nas quais se cometeu um grande erro, e, apesar disso, não apresentam danos importantes. Em contrapartida, é comum estruturas que apresentam danos graves que se produziram como conseqüência de causas de menor importância mas que atuam simultaneamente, superpondo seus efeitos.

Segundo CANOVAS (1977) ao se observar as condições e causas mais prováveis de falhas, pode-se estabelecer a seguinte classificação:

1. Uso normal e utilização em condições normais ou em condições desfavoráveis - representam as degradações ao longo da vida útil, fruto da degradação dos materiais e está relacionada com a qualidade do projeto e da execução.

2. Modificações do solo e ação dos lençóis freáticos, influências externas (incêndios, inundações, explosões, etc.) e movimentos sísmicos ou ações similares de tipo oscilatório - são totalmente imprevisíveis, porém alguns efeitos, como recalque nos alicerces, ações sísmicas, vibrações, etc., podem ser previstos; assim, pode-se diminuir e, inclusive, eliminar muitos danos, mediante a adoção de determinadas medidas construtivas adequadas.

3. Utilização inadequada (sobrecargas), erros de projeto ou de execução representam a maior porcentagem de danos evitáveis. De todas essas causas, as devidas a erros ou descuidos na execução são as que maior porcentagem de danos ocasionam.

Segundo o autor, pode-se apontar como última causa as chamadas inevitáveis, devidas a hipóteses de cálculos não muito corretas, falta de precisão em resultados, erros acumulativos em cálculos etc, e em geral, na falta de coincidência da teoria com a realidade.

BAUER (1985) menciona que a maioria dos danos ocorridos nos elementos estruturais são do tipo evolutivo e que, com um prazo mais ou menos curto, poder comprometer sua estabilidade. 
0 autor apresenta outra classificação de deterioração de uma estrutura, mais direcionada, que pode estar relacionada com diversas causas que são subdivididas em quatro grupos sendo eles:

- Grupo I - Erros de projeto estrutural;

- Grupo II - Emprego de materiais inadequados;

- Grupo III - Erros de execução;

- Grupo IV - Agressividade do meio ambiente.

CANOVAS (1988) cita que BLEVOT (1974) analisou obras francesas que causaram sinistros entre o período de 1948 e 1974 e conseguiu elaborar uma distribuição percentual dessas causas chegando aos seguintes números:

- erros de concepção geral $=3,5 \%$ (desse, os que concernem à concepção da estrutura ou interessam à estabilidade, são $0,7 \%$ )

- erros de hipóteses de cálculo, erros de materiais e ausência de estudos $=8,5 \%$

-disposições defeituosas (fundamentalmente na disposição de armações) em certos elementos ou na transmissão de esforços $=2,5 \%$

- falhas resultantes de deformações excessivas $=19,7 \%$

- falhas resultantes dos defeitos de variações dimensionais $=43,7 \%$

$\Rightarrow$ terraços, balcões, cornijas e elementos externos de um edificio: $26,5 \%$

$\Rightarrow$ Elementos de concreto armado sob sótãos, insuficientemente isolados: $5,0 \%$

$\Rightarrow$ União de pavimentos e elementos estruturais: $10,0 \%$

$\Rightarrow$ Os que afetam abóbadas de tijolo ou de concreto: $2,2 \%$

- defeitos de execução $=16,5 \%$ desdobrados em: cimbramento com $2,0 \%$, concretagem acumulando $4,0 \%$, armação com 7,0\%, descimbramento em $0,5 \%$, causas múltiplas (concreto e aço defeituosos) somando 1,5\% e finalmente falsas manobras com 1,5\%

- fenômenos de tipo químico 4,0\% e de gelo, desdobrados em: decomposição do concreto e corrosão de armaduras com $1,5 \%$, efeitos do gelo em $2,5 \%$ e causas diversas com $1,6 \%$.

Conforme LIBÓRIO \& DOREA (1996), quando se realiza um projeto de Engenharia, deve-se conhecer obrigatoriamente as chamadas "necessidades dos usuários", que se apresentam em 14 exigências através da Tabela 09 e foram elaboradas a partir da Norma ISO-DP-6241. 
TABELA 09 - Necessidades dos Usuários: Transformação em Exigências, Norma ISO-DP-6241

\begin{tabular}{|c|c|}
\hline EXIGÊNCIA & DESCRIÇÃO \\
\hline 1. DURABILIDADE & $\begin{array}{l}\text { - Conservação e desempenho ao longo do } \\
\text { tempo. }\end{array}$ \\
\hline $\begin{array}{l}\text { 2. SEGURANÇA } \\
\text { ESTRUTURAL } \\
\end{array}$ & - Estabilidade e Resistências Mecânicas \\
\hline 3. ECONOMIA & $\begin{array}{l}\text { - Custo inicial, custo de manutenção, } \\
\text { reposição durante o uso. }\end{array}$ \\
\hline 4. SEGURANÇA AO & $\begin{array}{l}\text { - Limitações ao risco de início e propagação } \\
\text { de incêndio e segurança dos usuários. }\end{array}$ \\
\hline $\begin{array}{l}\text { 5. SEGURANÇA À } \\
\text { UTLLIZAÇÃ̃O }\end{array}$ & $\begin{array}{l}\text { - Segurança dos usuários e segurança a } \\
\text { intrusões. }\end{array}$ \\
\hline $\begin{array}{l}\text { 6. CONFORTO } \\
\text { HIGROTÉRMICO }\end{array}$ & - Temperatura e umidade do ar e das paredes. \\
\hline 7. CONFORTO ACÚSTICO & - Isolação acústica e níveis de ruído. \\
\hline 8. CONFORTO VISUAL & $\begin{array}{l}\text { - Aclaramento, aspecto dos espaços e das } \\
\text { paredes, vista para o exterior. }\end{array}$ \\
\hline 9. ESTANQUEIDADE & - Aos gases, líquidos e aos sólidos. \\
\hline 10.ATMOSFÉRICAS & - Pureza do ar e limitacão de odores. \\
\hline 11.CONFORTO TÁCTIL & $\begin{array}{l}\text { - Eletricidade estática, rugosidade, umidade, } \\
\text { temperatura da superficie. }\end{array}$ \\
\hline $\begin{array}{l}\text { 12.CONFORTO } \\
\text { ANTROPODINÂMICO }\end{array}$ & $\begin{array}{l}\text { - Acelerações, vibrações e esforços de } \\
\text { manobra. }\end{array}$ \\
\hline 13.HIGIENE & $\begin{array}{l}\text { - Cuidados corporais, abastecimento de água, } \\
\text { eliminação de matérias usadas. }\end{array}$ \\
\hline $\begin{array}{l}\text { 14.ADAPTAÇÃO À } \\
\text { UTILIZAÇÃO } \\
\end{array}$ & $\begin{array}{l}\text { - Número, dimensões, geometria e relações de } \\
\text { espaco e de equipamentos necessários. }\end{array}$ \\
\hline
\end{tabular}

\section{2 - A IMPORTÂNCIA DO PROJETO E SUAS FASES}

Segundo LIBÓRIO (1994), um dos quesitos fundamentais para realização de um empreendimento encontra-se exatamente na realização do PROJETO.

Esse instante de concepção do produto construção é, talvez a parte mais importante a ser analisada pois, aqui serão elaboradas todas as hipóteses necessárias que devem ser suficientes para uma perfeita execução do objeto a construir.

É nesse instante, por exemplo, que os melhores materiais serão escolhidos para compor determinado produto e que deverão satisfazer com qualidade e durabilidade toda 
a construção. Além disso, haverá que se pensar nos controles necessários para alcançar os objetivos do produto construção. Por fim, esses controles deverão privilegiar, através de perfeito entendimento, o conhecimento das atividades do construtor e, por conseguinte, em quem irá realizar a composição ou montagem dos subsistemas que deverão integrar o produto construção.

Torna-se necessário considerar que, na Engenharia Civil, a realização de qualquer obra, pressupõe-se um conhecimento e competência multidisciplinar para que a construção possa enfrentar as ações ambientais e de utilização, por determinado período, até sua obsolescência.

De acordo com ORLANDI (1983), o projeto pode ser ordenado cronologicamente em três fases:

- ESTUDO PRELIMINAR

- ANTE PROJETO

- PROJETO EXECUTIVO

Dependendo das especificidades de cada obra, podem ainda ocorrer outras duas fases:

\section{- PROJETO BÁSICO E PROJETO LEGAL}

Cada uma dessas fases podem ser associadas a diversas atividades e objetivos intrínsecos dependente da tipologia da obra:

- PROJETO PRELIMINAR - Concepção da obra, sua viabilidade e exeqüibilidade, as diretrizes e restrições, os objetivos e alternativas, a alternativa final.

Essa fase é o instante da concepção. Cabe lembrar que o Brasil é um País extenso, e se percorre mais que $5000 \mathrm{~km}$ entre os extremos Norte $\mathrm{x}$ Sul e Leste $\mathrm{x}$ Oeste. Isso significa uma variação grande em termos de clima, costumes, materiais, agressividades etc.

Aqui, o engenheiro ou arquiteto deverá ter em mente que, qualquer atividade que demande tempo, deverá ser com certeza controlada e representará custo. Um erro nessas avaliações poderão transformar-se em sérios prejuízos.

- ANTEPROJETO - Concentração completa em termos arquitetônicos e construtivos do partido geral da obra; serve também para fins de apresentação de projeto. 
Esta fase prevê que todos os aspectos arquitetônicos e construtivos sejam apresentados em termos do partido geral da obra somados aos quesitos estudados no Estudo Preliminar.

- PROJETO EXECUTIVO - Detalhamento arquitetônico construtivo iniciado com o Projeto Básico; compõem-se de plantas, desenhos, memoriais descritivo e executivo, especificações técnicas, quantificação de materiais e serviços, orçamentos e custos.

É nesse instante que se observa um grande número de falhas que estarão refletidas no instante da execução. Trata-se da ocasião em que haverá uma descrição detalhada de todas as atividades que deverão ser desenvolvidas pelo agente construtor. Um erro nesse instante significará uma transferência do momento e da tomada de decisão para o empreiteiro que, preocupado com outras questões, poderá não tomar ou adotar a conduta mais correta e adequada.

Os materiais a serem empregados deverão estar verificados quanto à sua disponibilidade e qualidade. Também os custos para eventuais explorações deverão estar analisados.

Nas plantas, desenhos e nos detalhes de situação final, dependendo da tecnologia e técnica adotadas, o procedimento executivo deverá estar previsto. Todas as atividades, sem exceção, deverão ser contempladas no memorial descritivo: distâncias, caminhos, controles, materiais e seus proporcionamentos, áreas de estocagens e reservas, restrições, horários de aplicação de cada atividade etc.

A deteção do comportamento do meio ambiente e micro-regiões viciadas durante a realização do evento construção e os comportamentos futuros deverão fazer parte das análises do projeto.

O comportamento da construção frente à sua utilização e susceptibilidade ao meio ambiente, plenamente justificado, deverão constar em manuais a serem apresentados nessa ocasião ao responsável pelo empreendimento.

A compatibilidade dos sub-projetos dos vários subsistemas que comporão o produto deverá estar plenamente resolvida e exaustivamente verificada de modo que não hajam dúvidas na execução. 
Os procedimentos de controle também deverão ser abarcados para que as características geométricas dos elementos estruturais estejam condizentes com os elementos previstos na construção (por exemplo, compatibilidade de distâncias entre pilares e aplicação de alvenaria de tijolos com dimensões normalizadas e padronizadas, emboço e revestimentos cerâmicos).

- PROJETO BÁSICO - Primeira etapa do detalhamento executivo da obra, elaborado para fins de apropriação de custos, avaliação de materiais e técnicas executivas a empregar e para efeito de contratação da obra.

Nem sempre os autores dos projetos são os responsáveis pela execução do empreendimento. Essa fase consiste em transferir todas as informações básicas necessárias para proceder-se a viabilização técnica do empreendimento. Deverá dar subsídios para quantificar os materiais anteriormente especificados e seus custos básicos, e poderá permitir, através de procedimento técnico-científico adequado, plenamente justificado, sua composição final, forma e planejamento de aplicação em local definitivo.

Nesse instante, todo o planejamento de atividades, seu aceleramento ou desaceleramento deverá ser estudado, para fins de apresentação de custo em concorrência ou, para expor e justificar ao contratante a adoção da técnica a ser viabilizada por ocasião da concretização do empreendimento.

- PROJETO LEGAL - Acervo de elementos gráficos e descritivos necessários à aprovação do projeto pelos poderes públicos intervenientes.

Ao se propor a realização de determinado empreendimento, haverá a necessidade de obter aprovação junto aos órgãos públicos competentes e intervenientes no contexto de aplicação da construção. Como exemplo desses órgãos, citam-se as Prefeituras, CETESB, concessionárias locais (companhias de água e esgoto, energia elétrica, telefonia), Corpode-Bombeiros, DER, CREA, IBAMA, etc.

Também haverá de se considerar as condições de contorno da obra e, suas interferências (obras limítrofes, dutovias, aerovias etc.), assim como as recomendações de plano diretor local.

\section{3 - ATIVIDADES DO CONSTRUTOR}


LIBÓRIO (1994) esclarece que uma vez bem definidas as fases de projeto é importante realçar todas as atividades que deverão ser desenvolvidas pelo agente construtor. Isso porque, um erro no instante do projeto executivo, por exemplo, significará uma transferência do momento e da tomada de decisão para o construtor que, preocupado com várias questões, listadas a seguir, poderá não adotar a conduta mais correta e adequada.

1. garantir as hipóteses de projeto;

2. obter áreas para implantação do(s) canteiro(s) de obra(s);

3. estabelecer áreas de empréstimo para busca de parte dos materiais a ser introduzida na construção e respectivas estocagens;

4. adquirir, garantir a qualidade e controlar o recebimento de materiais;

5. operacionalizar o fluxo de materiais e otimizar sua utilização;

6. contratar a mão-de-obra especializada ou não;

7. adaptar a mão-de-obra às peculiaridades do projeto;

8. controlar a produção e a qualidade dos serviços executados, especificados no projeto;

9. compatibilizar a disponibilidade de recursos financeiros com os recursos materiais $\mathrm{e}$ humanos ao longo do tempo, em função do custo financeiro da empresa;

10.otimizar equipes, equipamentos e instalações de apoio;

11.conduzir e participar de reuniões técnicas ligadas à obra e/ou empresa;

12.estabelecer empresas de apoio;

13. viabilizar a continuidade de empreendimentos, etc.

Muitas vezes, se o projeto não determina com clareza de detalhes a forma mais correta para determinada etapa construtiva, nem mesmo o construtor (responsável pela obra) é consultado, ou seja, o próprio operário, sem qualificação adequada para decisão de projeto, decide a forma de executar conforme seus conhecimentos baseados em costumes e vícios fortemente arraigados na sua cultura construtiva.

A transferência de momentos de decisão (projeto $\Rightarrow$ execução), por si só, já constitui um agravante dado que no momento da execução, em geral, o tempo para tomar decisões é bastante curto, o que não contribui para alternativas bem pensadas, melhor elaboradas etc. 
Muitas patologias tem se originado à partir da execução de obras, pelo descaso no planejamento das atividades, controles inexistentes ou inadequados e insuficientes, mão de obra desqualificada executando atribuições que exige competência técnica, ocorrência de engenheiros e arquitetos que estão despreocupados com a execução, transferindo as responsabilidades para operários que têm o seu aprendizado de maneira empírica, etc.

Apesar da frase tipicamente usada por alguns profissionais de que "a prática é diferente da teoria" as obras, independentemente do instante, sempre deverão ser tratadas tecnologicamente pois só assim se pode fazer uso de uma determinada tecnologia.

Esse tratamento deve-se prolongar ao longo da vida útil da construção e é parte do tratamento inerente ao comportamento dos materiais e suas partes.

As maquiagens produzidas apenas escondem por um curto prazo os problemas e, as intervenções durante o uso custam, com raríssimas exceções, muito mais caras que o elemento estrutural a ser reparado ou outros subsistemas em processo de degradação.

\section{4 - CONSIDERAÇÕES SOBRE OS MATERIAIS PARA SE EVTTAR}

\section{PATOLOGIAS}

Uma grande parte dos defeitos que aparecem nas obras de concreto armado são devidos à pouca qualidade dos materiais empregados nelas, ao emprego inadequado desses materiais para o fim a que são destinados e ao meio ambiente a que serão expostos.

Em nossas estruturas o material mais utilizado é o concreto armado, entendendose por esse a mistura do cimento, agregados, água, armadura e eventualmente aditivos e adições.

A Patologia do concreto armado portanto está condicionada a Patologia dos seus constituintes, sendo que estes devam reunir características que impeçam a produção de defeitos a curto ou longo prazo.

\subsection{1 - Cimento}

O cimento Portland é de todos os cimentos disponíveis no mercado o que mais se encontra até o momento na obras correntes.

Devido esse fato serão elucidados os fatores que por ventura venham a exercer um ação maléfica sobre os concretos que são feitos por ele. 
CANOVAS (1977) ressalta que os defeitos ocorridos na sua produção, as alterações produzidas por má conservação ou mal emprego do cimento podem repercutir desfavoravelmente em suas resistências, em sua estabilidade ou nos concretos por ele fabricados ou ainda na durabilidade dos mesmos.

Os silicatos são os principais responsáveis pela resistência mecânica do cimento. Os aluminatos determinam o enrijecimento e a pega de um cimento. Porém, quanto maior a quantidade de aluminato, maior será a possibilidade de agressão do concreto por cloretos.

Outro ponto importante a se considerar no cimento é seu calor de hidratação devendo-se determinar o calor de hidratação total e a temperatura que ele pode atingir na massa de concreto a fim de limitar possíveis retrações térmicas e aplicar terapias para que essas não dêem lugar à fissuração do concreto.

O cimento será estável se, uma vez colocado nas argamassa ou concreto, seus componentes não sofram expansões nocivas ou destrutivas.

Um efeito patológico que o cimento pode apresentar na fase de pega e endurecimento é a chamada "falsa pega", que consiste em um prematuro empelotamento da pasta com duração de um a cinco minutos depois de começada a mistura. A causa mais comum desse efeito é desidratação parcial do gesso, sendo essa ação devida a um excesso de temperatura durante a moagem do cimento. $O$ gesso semi-hidratado quando dentro do cimento desencadeia um rápido endurecimento da massa que dá lugar à falsa pega. Esse empelotamento prematuro pode induzir o cimento a utilizar mais água criando problemas de baixas resistências e de retração.

Junto com a resistência mecânica, a estabilidade é uma das propriedades mais importantes do cimento.

A cal livre é um constituinte freqüente nos cimentos sendo sua presença decorrente de um defeito da fabricação atribuído a diversas causas. A hidratação da cal livre é expansiva, podendo dar lugar a fissuras superficiais no concreto inclusive debilitando e até destruindo o mesmo. A cal liberada na hidratação é por sua vez atacada por águas puras, ácidas e carbonatadas. 
Os álcalis do cimento provêm da matéria prima sendo em geral da argila, influindo negativamente em outro aspecto da durabilidade devido à possibilidade de se ocorrer reações entre os álcalis e os agregados.

Cimentos com alto teor de trióxido de enxofre $\left(\mathrm{SO}_{3}\right)$ podem transformar-se em cimentos expansivos.

Quanto à conservação das propriedades do cimento, é essencial um adequado armazenamento como guardá-lo em local completamente seco e não deixar os sacos em contato direto com o chão devendo para isso dispô-los em tablados de madeira. Deve-se evitar também contato com correntes de ar, principalmente se esta for úmida.

\subsection{2 - Agregados}

A partir de que o quantil de agregados que constitui um concreto varia de $70 \%$ a $80 \%$, não é de se estranhar que sua influência tenha grande importância sobre as propriedades do concreto.

Ao se ignorar a granulometria dos agregados podem ser criados problemas como bicheiras ou então o excesso de finos fazer com que o concreto necessite de excessivas quantidades de água.

Outros problemas gerados pelo excesso de finos no agregado são de criar descontinuidades na pasta hidratada pelo fato das partículas finas presentes $(<0,075 \mathrm{~mm})$ se interporem com as partículas de cimento.

CANOVAS (1977) defende que a forma do agregado graúdo e sua compacidade assumem grande influência na qualidade do concreto. Por assim dizer, a resistência de um concreto será maior quanto maior for a compacidade do agregado empregado, pois se terá um menor número de vazios e por conseguinte, menor será a quantidade da pasta de cimento a se empregar tornando o concreto mais econômico. Por outro ângulo, a durabilidade do concreto será maior com o decorrer do tempo.

Os agregados não devem reagir com o cimento resultando em produtos expansivos que possam criar tensões internas na massa do concreto, que alterem ou diminuam a resistência mecânica ou a durabilidade deste. 
Entre os agregados considerados nocivos, encontram-se algumas variações de quartzo amorfo como opalas, cristobalitas, etc., que ao se combinar com os álcalis do cimento resultam em produtos de maior volume que destroem o concreto.

Os agregados devem também ser isentos de limos, argilas, matéria orgânica, etc., que comprometam sua aderência com a pasta de cimento ou então que prejudiquem as reações de pega e endurecimento do concreto

Piritas e outros sulfuretos em contato com a atmosfera podem se oxidar resultando em sulfatos que desencadeiam o processo de expansão.

\subsection{3 - Água}

Pelo ponto de vista patológico, o emprego de águas não potáveis e águas não comprovadas pode criar problemas a curto e longo prazo no concreto.

Em concreto armado, o emprego de água com quantidade de íon cloreto superior a $6 \mathrm{~g} / 1$ pode desencadear o processo de corrosão das armaduras.

A limitação de sulfatos na água se deve à reação que se desencadeará entre estes e o aluminato tricálcico do cimento dando lugar à etringita expansiva que resulta em fissuras, expansão e lascamento do concreto.

Deve-se também evitar águas contendo açúcares, glicose e outros hidratos de carbono pois estes podem impedir a pega do concreto.

\subsection{4 - Aditivos}

Os aditivos são produtos destinados a melhorar ou modificar no sentido positivo algumas propriedades do concreto fresco e endurecido. Subentende-se portanto que o papel do aditivo é corrigir possíveis deficiências, melhorar ou incrementar as boas qualidades e fortalecer o concreto. $O$ papel dos aditivos incide da mesma maneira que os medicamentos, pois como é sabido, estes apresentam um quadro de indicações e contraindicações que devem ser consideradas para se evitar problemas desagradáveis.

Um grande cuidado a ser observado ao se usar um aditivo é verificar se este já foi empregado anteriormente no país, pois pode ocorrer de produtos importados renomados serem incompatíveis com a matéria prima encontrada no país apresentando resultados 
insatisfatórios para nossos concretos mesmo que garantida sua qualidade nos países de origem.

Outro cuidado é quanto ao lote do aditivo devendo sempre ser certificado esse item para que se garanta que os produtos empregados tenham sempre a mesma composição e proporção química.

Existem aditivos como os plastificantes-fluidificantes que podem em certas ocasiões retardar início de pega e em outras podem acelerar a pega do cimento se este tiver pouco gesso ou se a porcentagem de aditivo empregado for muito grande.

Os aditivos incorporadores de ar e os aceleradores de pega são os que apresentam mais problemas. Os primeiros reduzem a resistência mecânica e este fator deverá sempre ser lembrado no momento de dosar um concreto que leve este tipo de aditivo. Os segundos, em geral de natureza salina, podem aumentar a retração, produzir eflorescências e motivar e acelerar a corrosão das armaduras.

Algumas vezes recorre-se a mistura de aditivos para se minimizar as ocorrências citadas acima. Porém, estas misturas podem ser muito perigosas podendo se produzir efeitos diferentes aos pretendidos inicialmente.

\subsection{5.- Armaduras}

As barras de aço devem todas estar de acordo com as normas brasileiras e seus respectivos diâmetros nominais devem estar obedecendo a NBR-7480 "Barras e Fios de Aço Destinados a Armaduras para Concreto Armado".

A fim de evitar erros que resultariam em manifestações patológicas, recomenda-se utilizar na obra o menor número possível de diâmetros distintos e que esses diâmetros se diferenciem o máximo possível.

Os aços das armaduras podem conter como elementos secundários carbono, enxofre, silício, magnésio ou escamas de laminação que formam recobrimentos descontínuos e ferrugem que favorecem a corrosão.

Os sais que porventura podem estar contidos nos componentes que constituem um concreto podem ter uma distribuição heterogênea dentro do concreto dando lugar a pilhas de concentração e aumentando a condutividade elétrica, acelerando portanto o processo de corrosão do aço. 
No momento de compactação de um concreto $o$ ar e a água tendem a subir para a superficie do elemento estrutural onde se encontram as barras longitudinais sendo que abaixo delas formam-se bolsas de ar mais pasta criando-se portanto uma região de heterogeneidade ao redor do diâmetro das barras que podem servir como fonte de corrosão eletroquímica. Este fenômeno está ligado de maneira diretamente proporcional à relação água/cimento do concreto, ou seja, maior será o fenômeno quanto maior for a relação água/cimento.

$O$ cimento protege o aço devido sua alcalinidade sendo portanto os cimentos ricos em cal os mais eficazes contra a corrosão, tendo destaque o cimento Portland.

A fissuração que aparece no concreto como consequência da corrosão do aço apresenta-se na forma de linhas paralelas seguindo a direção das barras longitudinais e dos estribos. A intensidade dessas fissuras depende do avanço do fenômeno corrosivo podendo chegar a aparecer trincas e disgregações toda vez que o aumento do volume de óxido passar de 10 vezes o diâmetro nominal do aço ou se as tensões atuantes devido esta expansão for muito grande.

\subsection{6 - Cura}

A cura da superficie de concreto é um dos fatores mais importantes na garantia da qualidade do concreto de cobrimento.

Apesar dela não ser um constituinte do concreto, ela é indispensável e deve ser realizada em toda e qualquer estrutura de concreto armado.

Apesar dela ser normalizada, é raro encontrar casos de obras que realizem a verdadeira cura.

Em função disso, torna-se fácil a detecção de muitas patologias devidas a sua ausência, pois a não realização da cura não só vai aumentar a permeabilidade do componente estrutural como um todo, mas, principalmente, cria condições para o desenvolvimento de uma série de fissuras no concreto, numa profundidade da ordem da espessura do cobrimento. Todos os fenômenos de permeabilidade à água, a gases, absorção de água, retenção de fuligem, difusão de agentes agressivos, etc., serão intensificados e comprometerão a proteção da armadura. 
O ganho de resistência de um concreto ou argamassa depende, entre outros parâmetros, fundamentalmente do processo de cura. Para NEVLLE (1982) o objetivo da cura é manter o concreto saturado, ou o mais próximo possível dessa condição, até que os espaços inicialmente ocupados pela água na pasta fresca de cimento sejam preenchidos, até o ponto desejado, pelos produtos de hidratação do cimento. Outra observação importante é quanto ao fato da hidratação do cimento só poder se efetuar nos capilares cheios de água. Por esse motivo, deve ser evitada a perda da água nos capilares.

Outros autores afirmam que a cura é possivelmente a operação mais importante para a execução de elementos de concreto, pela influência decisiva que confere à resistência $\mathrm{e}$ às demais qualidades do elemento final.

Sendo assim, uma falta de cura ou uma cura ineficiente é sem sombra de dúvidas o principal motivo para as fissuras contíguas nas peças e, principalmente nas lajes, devido às suas maiores superficies de exposição e a diferentes gradientes de temperatura.

Além dos cuidados com a cura, deve-se ponderar a cada concretagem, as condições climáticas em que se realizam as concretagens.

Após a concretagem das peças, deve-se começar imediatamente o ciclo de cura.

De acordo com a NB-1 essa cura deve ser feita após o início da pega, nas primeiras idades de enrijecimento do concreto, e se estender por um período mínimo de sete dias com ciclos de molhagem ininterruptos, aumentando-se esse mínimo quando a natureza do cimento exigir.

No caso da cura convencional (úmida) estar sendo executada em dias quentes, os cuidados devem aumentar, garantindo-se uma lâmina d'água por toda superficie dos elementos estruturais, pois a evaporação é muito mais rápida que em dias frios.

Para as lajes, vigas, pilares e paredes no caso de edificios, a cura mais simples, mais utilizada é a cura úmida baseada em molhar os elementos estruturais.

Para elementos estruturais verticais (pilares e paredes) essa cura pode ser feita através do envolvimento das peças em sacos de aniagem ou os próprios sacos de cimento vazios umedecidos constantemente e ininterruptamente.

Para as vigas pode-se usar dois métodos conjuntamente, ou seja, manter as superficies molhadas e envolver suas laterais e fundo em sacos de aniagem. 
Após esses primeiros sete dias de cura, as molhagens podem ser mais esparsas, considerando obviamente as características do concreto, porém devem continuar pelo menos até o décimo quarto dia, quando o concreto já está mais próximo das suas características de resistência especificadas.

No caso de uma cura ser insuficiente ou não ser realizada, desrespeitando o mínimo estipulado pela NB-1, o concreto não chega a atingir o endurecimento esperado, tornando-se vulnerável a agentes prejudiciais como as mudanças bruscas de temperatura, secagem, chuva forte, água torrencial entre outros, podendo surgir fissuração na massa do concreto ou prejudicar a sua aderência à armadura.

Com o surgimento de fissuras nas superficies expostas do concreto, e principalmente nas lajes, criam-se caminhos mais suscetíveis a agentes deletérios.

Nos ciclos de molhagem e secagem a que as lajes são submetidas por causa das chuvas, por exemplo, a água começa a penetrar pelas fissuras "lavando" o concreto e carreando consigo o hidróxido de cálcio advindo da hidratação da pasta de cimento para a superficie protegida da laje, caracterizando a lixiviação do hidróxido de cálcio.

Esse produto lixiviado interage com o $\mathrm{CO}_{2}$ (gás carbônico) presente no ar e resulta na precipitação de crostas brancas de carbonato de cálcio na superficie, originando as chamadas eflorescências.

A cura pode ser realizada por via úmida ou térmica, sendo a primeira mais utilizada.

Sendo assim, mesmo que tomado todo tipo de cuidado com os componentes de um concreto bem como com o próprio concreto, a fim de atingir os quesitos preestabelecidos de durabilidade em uma estrutura, fatalmente o elemento estrutural apresentará algum problema patológico podendo atingir toda estrutura ao longo de sua vida útil se não realizada a cura.

\section{5 - FATORES QUE DELIMITAM AS PATOLOGIAS NAS}

\section{ESTRUTURAS DE CONCRETO ARMADO}

Conforme citações de CANOVAS (1977) seja qual for o problema que alguns dos componentes de um concreto venha a apresentar, este se refletirá desfavoravelmente sobre as características mais importantes do concreto: resistência mecânica, estabilidade e 
durabilidade. Estas três características estão relacionadas com outros fatores entre os quais cabe destacar a homogeneidade e a compacidade do mesmo.

A segregação ou separação dos materiais mais densos para as regiões inferiores e a exudação ou elevação da pasta para a superficie, fazem com que os concretos não permaneçam uniformes. Ambos fatores podem se originam da natureza, dosagem, relação água/cimento, aditivos empregados, etc.

Todas essas causas que interferem negativamente na uniformidade, pertencem a fase de projeto.

Outras causas que levam à heterogeneidade e à falta de compacidade dependem de operações realizadas com o concreto fresco, tais como o transporte, vibração, colocação de ferragem e espaçadores. Todas estas operações que pertencem à tecnologia do concreto, têm grande influência em sua homogeneidade e suas falhas entram dentro da patologia devida à execução.

Dois são os parâmetros mais importantes que influenciam no projeto e tecnologia do concreto: um é a relação água/cimento e o outro é a relação água/agregado.

Deles vão depender não só a compacidade do concreto como também a estabilidade e a durabilidade de um concreto ao longo do tempo.

\section{6 - POSSÍVEIS DEFEITOS DE PROJETO ADVINDOS DA FALTA DE}

\section{CRITÉRIOS E DETALHAMENTOS}

A pretensão deste item é expor de maneira simples alguns critérios e condutas que devem ser tomados ao se projetar uma estrutura de maneira que sejam evitados grandes erros de projeto. Alguns desses critérios são de conhecimento de todos os profissionais envolvidos em uma construção. Porém pelo descuido ou complexidade de algumas condutas, deixa-se de empregar algumas atitudes que se refletem automaticamente em problemas na obra. São apresentados também alguns problemas patológicos possíveis de serem encontrados e aqueles cujas falhas são propositadas pela pura falta de importância ao se elaborar um projeto como, por exemplo, pelo acréscimo de sobrecarga.

Vários autores, nos seus estudos sobre patologias, listam inúmeras falhas observadas em projetos estruturais. 
Dentre esses autores, BAUER (1985) aponta nos seus estudos sobre patologias, as prováveis causas de deterioração em grupos. Ele relaciona no chamado "Grupo P" as causas decorrentes de erros de projeto estrutural que são:

- falta de detalhamento ou detalhes mal especificados;

- cargas ou tensões não levadas em consideração no cálculo estrutural;

- variações bruscas de seção em elementos estruturais;

- falta, ou projeto deficiente de drenagem;

- efeitos de fluência do concreto, não levados em consideração.

LIBÓRIO (1989), além de detalhar as falhas colocadas acima, incrementa essa relação listando também:

- detalhamentos insuficientes;

- análise deficiente de locais críticos;

- ausência de informações;

- falta de clareza das informações;

- detalhes inexeqüíveis;

- falta de padronização das informações;

- expectativas não cumpridas do sistema construtivo adotado;

- ausência de elementos que permitam avaliações de custos, de materiais, de técnicas executivas e de equipamentos necessários para efeito de contratação da obra;

- memoriais descritivos;

- especificações técnicas;

- incompatibilidade da seqüência construtiva, em vista da concepção do projeto, sob todos os aspectos;

- incompatibilidade entre diversos projetos $\mathbf{e}$

- falhas nos diversos projetos.

CANOVAS (1977) ressalta que ao se conceber um projeto de estrutura deve-se levar em consideração quatro fatores essenciais para qualquer que seja a estrutura. Estes fatores resumidamente são:

- a necessidade de que garantam as condições de equilíbrio básicas da Estática;

- compatibilidade entre as deformações e as uniões dos elementos estruturais; 
- a necessidade de um completo detalhamento em escala suficientemente clara;

- a elaboração de um memorial descritivo que descreva a obra por completo, explicitando os materiais à serem adotados, detalhes construtivos, etc.

Outro cuidado muito importante que ganha espaço hoje é o fato da existência de muitos programas computacionais para cálculos estruturais. Mesmo havendo grande margem de exatidão nos cálculos, sempre será necessário a verificação e interpretação dos resultados por um calculista.

Pelo ponto de vista patológico, uma equipe com vários profissionais pode evitar muitos erros reunindo-se para juntos chegar a soluções para casos complicados mediante suas experiências profissionais aliados aos conhecimentos técnicos.

Um passo tão importante quanto o projeto e a execução é a fase intermediária a estes dois instantes da obra pois uma despreocupação com a organização nessa etapa como deficiência de comunicação e planejamento da obra podem gerar um número muito grande de erros por falta de interpretação dos projetos carregando esses erros para a execução.

DINIZ (1998) cita que o texto provisório da NBR-6118 ressalta que para evitar envelhecimento precoce e satisfazer as exigências de durabilidade dos usuários, deve-se seguir os seguintes critérios de projeto:

- prever drenagem eficiente;

- evitar formas arquitetônicas e estruturais inadequadas;

- garantir concreto de qualidade apropriada, particularmente nas regiões superficiais dos elementos estruturais;

- garantir cobrimentos de concreto apropriados para proteção da armadura;

- detalhar adequadamente as armaduras;

- controlar a fissuração das peças;

- prever espessuras de sacrificio ou revestimentos protetores em regiões sob condições de exposição ambiental muito agressivas;

- e definir um plano de inspeção e manutenção preventiva.

O autor elucida que, segundo os critérios do texto provisório, todas as superficies expostas que necessitam ser horizontais devem ser drenadas assim como todas as juntas de movimento ou dilatação devem ser seladas e todos os topos de platibandas e paredes 
devem conter chapins. Essas medidas evitam que a água poluída se impregne no concreto deteriorando-o.

O texto menciona também que as barras devem ser dispostas de modo a garantir $\mathrm{e}$ facilitar um bom adensamento. Isso significa prever durante o detalhamento de disposição das armaduras, espaço suficiente para entrada da agulha do vibrador.

Quanto ao cobrimento, o texto explica que o cobrimento mínimo se constituirá do cobrimento nominal ${ }^{1}$ acrescido da tolerância de execução (AC sendo igual a $5 \mathrm{~mm}$ para controle rigoroso e $10 \mathrm{~mm}$ para demais obras correntes).

Estabeleceu-se uma correspondência entre classe de agressividade do concreto e seu referente cobrimento nominal. Tais valores são mostrados na Tabela 10.

TABELA 10 - Correspondência entre classe de agressividade e cobrimento nominal. (DINIZ, 1998).

\begin{tabular}{|c|c|c|c|c|c|}
\hline \multirow{2}{*}{$\begin{array}{l}\text { Cobrimento } \\
\text { nominal } \\
\text { (mm) }\end{array}$} & \multirow{2}{*}{$\begin{array}{l}\text { componente } \\
\text { ou elemento }\end{array}$} & \multicolumn{4}{|c|}{ Classe de agressividade (Tabela 3) } \\
\hline & & $T$ & II & III & IV \\
\hline \multirow{2}{*}{$\begin{array}{l}\text { concreto } \\
\text { armado }\end{array}$} & laje & 15 & 20 & 30 & $40^{\sin }$ \\
\hline & viga/pilar & 20 & 25 & 35 & 45 \\
\hline protendido* & todos & 25 & 30 & 40 & 50 \\
\hline
\end{tabular}

Notas : * - cobrimento nominal da armadura passiva que envolve a bainha ou os fios, cabos e cordoalhas, sempre superior ao especificado para o elemento de concreto armado, devido aos riscos de corrosão fragilizante sob tensão.

** - para a face superior de lajes e vigas que serão revestidas com argamassa de contrapiso, com revestimentos finais secos tipo carpete e madeira, com argamassa de revestimento e acabamento tais como pisos de elevado desempenho, etc.

*** - nas faces inferiores de lajes e vigas de reservatórios, estações de tratamento de água e esgoto, condutos de esgoto, canaletas de efluentes e outras obras em ambientes quimicamente e intensamente agressivos, devem ter cobrimento nominal $\geq 45 \mathrm{~mm}$.

Apesar da proposta de revisão da NB-1 ser recente, RIPPER (1996) já mencionava que ao se detalhar uma armadura, é necessário se pensar em quais serão as dificuldades em se montá-las no local de aplicação da obra, tomando-se o cuidado de verificar a viabilidade de executar essas ferragens nas regiões tipicamente congestionadas como pé de pilar ou encontros de viga. Geralmente essas regiões de aglomerações não são detalhadas separadamente. 
$\mathrm{O}$ autor ainda cita que outro inconveniente comum nas obras é a falta de preocupação de se mostrar em projeto a indicação da armadura de espera nas bases para as colunas ou na continuação dos pilares para o pavimento superior. Na falta desses dados é comum o armador colocar as armaduras de espera na mesma posição da ferragem do pilar com o mesmo tamanho dos estribos deste. Assim, nunca sobra espaço entre os ferros de espera para a montagem do pilar obrigando o funcionário a tomar soluções inadequadas e erradas como por exemplo, dobrando os ferros de espera para dentro do pilar. A Figura 13 mostra como deveria ser esse detalhamento nos projetos estruturais.

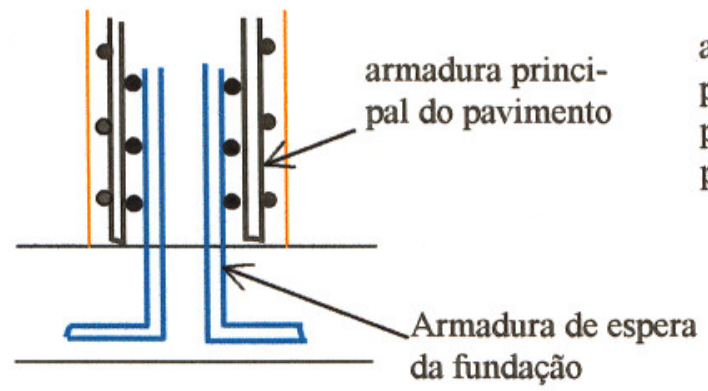

Posição da armadura de espera nas fundações

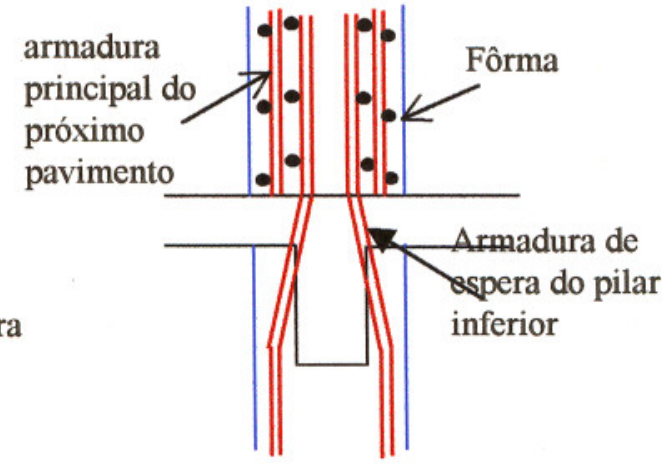

Armadura de transição
nos pilares sobrepostos

FIGURA 13 - Detalhes da armadura de traspasse em projeto (FONTE: Ripper,1996).

Outro problema comum de se encontrar é a indicação de simetria de armadura nas peças ou referência para peças similares. Geralmente quem interpreta esses desenhos na obra são os armadores que pela própria situação da obra (desenho sujo, visualização do desenho seguro nas mãos, etc.) fica passível de erros.

RIPPER (1996) é claro ao mencionar que é no projeto que deverá constar ainda o tipo de concreto exigido, indicando a resistência característica, $\mathrm{f}_{\mathrm{ck}} \mathrm{e}$ tipo de controle a que será submetida a obra (regular, razoável ou rigoroso).

Finalmente o autor ressalta que deve constar no projeto também a espessura de cobrimento da armadura e não deixar sua fixação a critério da obra.

\footnotetext{
${ }^{1}$ Cobrimento nominal - zona entre a superfície da peça e a face externa do estribo.
} 
A respeito da fixação do cobrimento, HELENE (1986) menciona ainda que algumas entidades fixam o cobrimento mínimo adequando-o às diferentes situações de exposição da estrutura ao meio ambiente, assim como a consideração de diferentes atmosferas, a microrregião onde se localiza o elemento estrutural, a natureza da solicitação mecânica a que estará sujeita e finalmente a qualidade das técnicas construtivas empregadas na obtenção da peça.

\section{7 - DEFEITOS DE EXECUÇÃO E FORMAS DE PREVENÇÃO}

A partir de pesquisas realizadas em campo, LIBÓRIO \& DOREA (1996), detectaram falhas próprias da execução. Ente os diversos defeitos de execução, eles listaram os seguintes:

- pilares mal posicionados;

- armadura de espera insuficiente;

- acréscimo de seção no topo de pilar;

- adensamento insuficiente;

- ausência de espaçadores;

- calafetação inadequada das fồmas;

- ausência de cura;

- reforço de viga no meio do vão;

- desfồma e descimbramentos inadequados.

Além dessas, existem outras falhas decorrentes da execução e que podem promover o surgimento de patologias, afetando a qualidade da construção como por exemplo: a utilização de agregados inadequados, dosagem inadequada do cimento, utilização de água agressiva para amassar o concreto, aplicação incorreta de aditivos, deixar em posição baixa a armadura negativa de vigas e lajes, diminuir o número de armaduras ou a seção indicada no projeto, alteração dos comprimentos de ancoragem das barras, utilização de barras oxidadas, montagem incorreta dos estribos, eliminação dos estribos nos apoios das vigas, utilização de um concreto com menor resistência que a especificada, concretagens em épocas quentes nas horas de máximo calor, interrupção da concretagem em pontos inadequados, etc. 
As patologias na execução são geralmente decorrentes das patologias de projeto, estando ambas ligadas entre si; entretanto tal afirmação não significa que um projeto perfeito garante uma execução sem erros.

Segundo CANOVAS (1977), para se evitar erros na execução de estruturas de concreto armado, todos os participantes dessa fase, desde o engenheiro responsável até o operador de vibrador devem saber exatamente como executar seus serviços. A falha de um desses elementos humanos, por negligência, desconhecimento das técnicas ou normas ou ainda devido a modificações que se façam necessárias para a adequação do projeto à realidade da obra pode causar graves erros e grandes prejuizos.

Geralmente existem algumas fases características que podem ocasionar problemas na execução.

A dificuldade na interpretação dos projetos aliados a dificuldades de se contactar o projetista pode levar o engenheiro a tomar decisões errôneas. É comum também, devido a grande número de atribuições do engenheiro na obra, haver dificuldades de comunicação deste com o mestre ou encarregado da obra levando o problema para frente.

É comum observar o contraventamento de pilares em uma única direção perpendicular a ele quando deveriam ser realizados em duas direções perpendiculares entre si. Quanto a sua fixação é comum também a aplicação de um ou dois pregos. Os contraventamentos podem receber esforços de tração e se as peças não estiverem bem fixadas podem se movimentar com facilidade saindo do prumo.

No caso de pilares altos, deve-se colocar duas linhas de contraventamento em alturas diferentes, pois estes estão sujeitos a flambagem.

RIPPER (1996) cita a necessidade também de prever janelas nas bases dos pilares para facilitar a limpeza e lavagem do fundo para a posterior concretagem.

No caso das lajes e vigas é comum verificar deslocamentos no alinhamento e deformações no caso das vigas devido à insuficiência de escoramentos e contraventamentos.

Segundo o autor, nas fôrmas laterais das vigas e das paredes as escoras verticais e horizontais não são suficientes devendo ser previstas mãos francesas entre a parte superior da escora vertical e a travessa do pontalete ou contra o piso ou terreno. Nas paredes altas deve-se prever mãos francesas em diversas alturas. Este escoramento evita o 
empenamento das fôrmas sob pressão do concreto fresco, garante o alinhamento da peça e evita as desagradáveis "barrigas" ou superficies tortas.

Outro fator que pode gerar peças desalinhadas é a falta de planejamento do início de lançamento do concreto criando tensões que provocam deformações nos elementos estruturais.

A falta ou mal fechamento das juntas nas fôrmas colaboram para o vazamento da nata de concreto no momento da concretagem. Esses vazios permitem a entrada de água que posteriormente podem atacar a armadura.

Quanto ao fechamento das fồrmas, recomenda-se o emprego de massa plástica ou mata juntas em substituição ao papel. Deve-se fazer essa calafetação pouco antes da concretagem, pois no caso das fồrmas ficarem expostas ao sol há a tendência delas se movimentarem promovendo assim o desprendimento da calafetação e perdendo com isso suas funções (mesmo que presentes).

Quanto às armaduras, deve-se sempre escovar sua superficie antes de empregá-las pois as camadas de ferrugem ou sujeira prejudicam a aderência com o concreto.

É comum observar elementos estruturais de concreto no estado endurecido e desformados com efeito parede e/ou sem cobrimento suficiente devido a inexistência de utilização de pastilhas ou espaçadores.

Quanto à ancoragem das peças, é comum encontrá-la executada de maneira errada. Pode-se observar na Figura 14 os erros mais comuns e a forma pela qual deveria ser feita. 

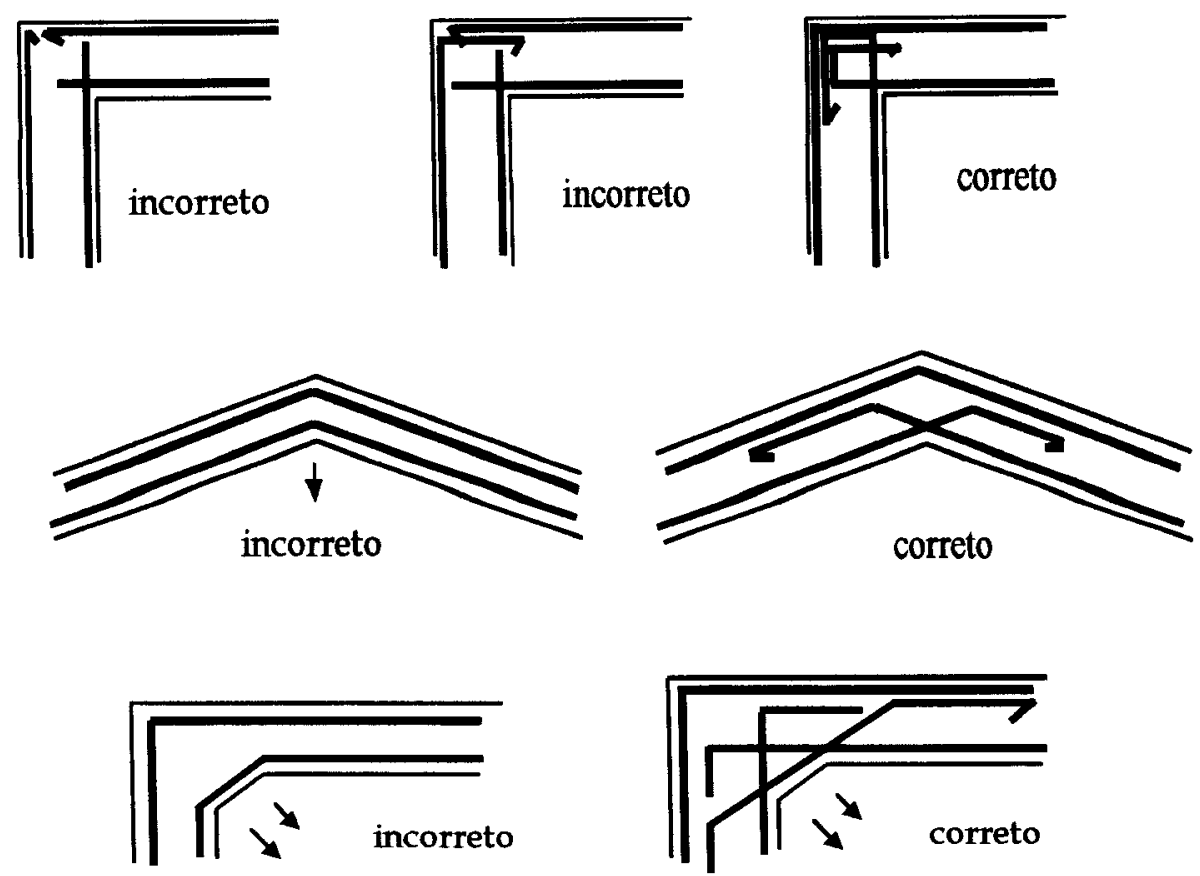

FIGURA 14 - Detalhes de emendas das barras (FONTE: CANOVAS, 1977)

Nas pequenas obras onde praticamente inexiste controle é comum encontrar um concreto mal misturado devido a má limpeza da betoneira contendo concreto velho incrustado nas paletas.

Outro caso comum é o concreto muito fluido nas obras pois dificilmente o encarregado ou mestre faz uma correção da relação água/cimento para quando a areia se apresenta muito úmida.

Recomenda-se usar para peças muito esbeltas ou com taxas de armaduras altas somente brita 1 de modo a se evitar as segregações e ninhos de concretagem.

No caso de uma obra consumir mais de um tipo de concreto, nunca é demais verificar se seu emprego está sendo correto.

Outro problema que dá a falsa impressão de inofensivo é a falta de limpeza das fôrmas sendo comum observar peças de concreto no estado endurecido com detritos incrustados.

É usual se constatar deslocamentos e deformações das armaduras no momento de lançamento do concreto por conta do mal posicionamento das plataformas e passadiços de serviço.

Depois de concretadas peças altas verifica-se muitas vezes que houve desagregação do concreto, fazendo com que haja concentração de agregado graúdo no pé 
do pilar devido a falta de janelas ou cachimbos na fôrma para se limitar a altura de queda fixada num máximo de 2,00 metros.

$\mathrm{Na}$ fase de endurecimento podem surgir fissuras de retração no concreto devido à ausência de cura.

RIPPER ( 1996) exemplifica como um caso típico de ausência de planejamento de desforma o caso de se deixar as escoras no meio do vão em vigas de grandes vãos; formase um apoio intermediário não previsto funcionando como um apoio para absorver momentos negativos. Ora, como o cálculo dessa viga não previu esse apoio surgem fissuras e trincas na parte superior da viga pela simples falta de armadura negativa.

Normalmente pode-se observar furos não previstos no concreto para passagem de tubulações, que por muitas vezes, por serem marcados errados, são deixados expostos nos elementos estruturais tornando-se os maiores contribuintes para penetração de agentes agressivos ao concreto.

\section{8 - SINTOMATOLOGIA}

A sintomatologia é uma reação das estruturas a um efeito anormal. Esta reação surge na forma de sinais externos que muitas vezes nos permite detectar de imediato qual é o problema.

Porém, existem algumas vezes que o sintoma alerta que há algum problema, exigindo entretanto, análises mais minuciosas de especialistas para se chegar a um diagnóstico correspondente ao sintoma observado.

As enfermidades apresentam os sintomas mais variados que podem ser mudanças de cor, lascamentos, expansões, fissuração, etc.

No caso de estruturas de concreto armado, a fissuração representa um dos sintomas patológicos mais importantes no seu comportamento em serviço.

Por outro lado, a fissuração é também o fenômeno conhecido mais antigo sendo portanto, o mais estudado até agora, o que permite que ao se detectar uma fissura se chegue a um diagnóstico com uma pequena probabilidade de erros. Isso não significa que sempre será fácil o diagnóstico de uma fissura. 
As expansões são os sintomas menos claros no momento de um diagnóstico e podem vir acompanhados por segregações ou disgregações.

A mudança de coloração no concreto pode vir de diferentes causas que vão desde a presença de cloretos e o emprego de aditivos inadequados até os componentes dos desmoldantes empregados nas fồrmas. Em geral, essas mudanças de coloração não proporcionam grandes preocupações do ponto de vista da resistência do concreto, provocando, no entanto, mal estar do ponto de vista estético.

É comum encontrar nas superficies das estruturas de concreto as chamadas eflorescências que serão abordadas mais adiante nesse capítulo.

Como já mencionado acima, devido ao fato das fissuras serem os sintomas mais freqüentes nas estruturas, será exposto de modo mais detalhado alguns dos principais , fenômenos que resultam nelas.

\subsection{1 - FISSURAS}

Teoricamente é possível realizar uma construção sem que surja nenhuma fissura, porém na prática ainda se nota sua ocorrência.

Em todas as construções com concreto armado, e portanto cimento, as fissuras aparecem ao longo dos anos, meses e até mesmo horas.

É imprescindível notar as informações que elas podem dar, como posição no elemento estrutural, abertura, trajetória, etc., pois são todas subsídios para descobrirmos a causa ou causas que as gerou.

As fissuras se dividem em microfissuras e macrofissuras sendo as primeiras não são perceptíveis a olho nu aparecendo no interior do concreto enquanto as segundas são as de comum reconhecimento.

Existe também a classificação das fissuras caracterizadas pelo concreto no estado plástico que origina um tipo de fissura totalmente diferente das fissuras classificadas no concreto endurecido.

Como uma última classificação, existem as fissuras que determinam o tipo de reparo que vão receber na sua recuperação. São elas as fissuras “vivas” que se encontram em movimento quando observadas e as fissuras "mortas" que se encontram estabilizadas. 
Segundo GIONGO \& SILVA (1994), a ocorrência de fissuras depende de diversas circunstâncias classificando-as em dois grupos:

- fissuras não produzidas por ações ( retração, dilatação térmica);

- fissuras produzidas por solicitações devidas ao carregamento.

No caso das fissuras não produzidas por cargas, segundo o autor, a análise é qualitativa. A Tabela 11 mostra, as causas, características e precauções a serem tomadas para esse tipo de fissura.

TABELA 11 - Fissuras não produzidas por cargas: causas, características e precauções. (GIONGO \& SILVA, 1994).

\begin{tabular}{|c|c|c|c|}
\hline Fase & Causas & Características & Precauções \\
\hline $\begin{array}{c}\text { período de cura } \\
\text { do concreto }\end{array}$ & $\begin{array}{c}\text { exposição ao sol } \\
\text { variação de } \\
\text { temperatura }\end{array}$ & $\begin{array}{c}\text { Aleatoriamente } \\
\text { dispersas, aparecem } \\
\text { logo após a } \\
\text { concretagem }\end{array}$ & $\begin{array}{l}\text { Proteger a superficie } \\
\text { usar menor relação } \\
\text { água/cimento }\end{array}$ \\
\hline & $\begin{array}{c}\text { deslocamento das } \\
\text { fôrmas }\end{array}$ & & $\begin{array}{l}\text { escoramento } \\
\text { conveniente }\end{array}$ \\
\hline $\mathrm{em}$ & Retração & $\begin{array}{l}\text { normais ao eixo, } \\
\text { aparecem depois de } \\
\text { semanas, com } \\
\text { abertura constante }\end{array}$ & $\begin{array}{c}\text { junta, cura } \\
\text { adequada, } \\
\text { diâmetros menores, } \\
\text { armadura dispersa }\end{array}$ \\
\hline \multirow[t]{2}{*}{ serviço } & dilatação térmica & & junta \\
\hline & $\begin{array}{l}\text { corrosão das } \\
\text { armaduras }\end{array}$ & $\begin{array}{c}\text { aparecem paralelas à } \\
\text { armadura }\end{array}$ & $\begin{array}{c}\text { adensamento, } \\
\text { cobrimentos } \\
\text { corretos }\end{array}$ \\
\hline
\end{tabular}

A princípio são abordadas as fissuras surgidas no estado plástico, para então serem apresentadas as fissuras no concreto endurecido.

\subsubsection{1 - Fissuração no estado plástico}

Surge no concreto nos estágios que vão do início ao fim de pega.

Ela são resultado de assentamentos diferenciais dentro da massa de concreto por sedimentação ou retração da superficie causadas pela rápida perda de água enquanto o concreto se encontra ainda plástico. Podem ainda ser originadas devido à combinação de endurecimento superficial com sedimentação interior. 
Na sedimentação, após o lançamento do concreto, os sólidos da mistura começam a sedimentar, deslocando a água e o ar aprisionado. A água aparece na superficie por exudação e a sedimentação continua até o endurecimento do concreto.

As armaduras e os agregados podem impedir a livre sedimentação do concreto obrigando-o a separar-se surgindo trincas no concreto plástico.(Figuras 15 e 16).

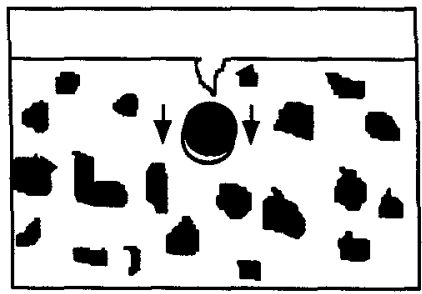

FIGURA 15 - Fissura de sedimentação pelo impedimento da armadura

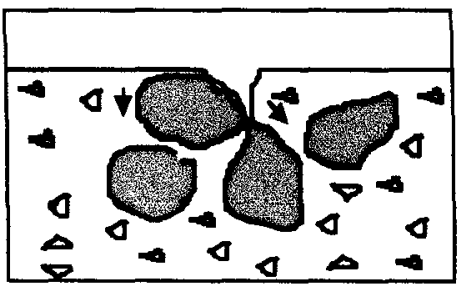

FIGURA 16 - Fissura de sedimentação pelo impedimento do agregado

As fissuras superficiais durante a fase plástica são causadas pela rápida evaporação da água da superficie do concreto e ocorrem geralmente quando o tempo está seco e quente.

Conforme RIPPER (1996), a evaporação depende da temperatura e umidade relativa do ar, além da temperatura da superficie do concreto e a velocidade do vento nessa superficie de concreto. Ou seja, mesmo que se utilize mesmos materiais, dosagens, acabamentos e cura, as fissuras e trincas ainda estão sujeitas a aparecer pois elas passam a depender exclusivamente das condições do tempo.

Outra causa que pode gerar fissuras no concreto quando no estado plástico é o mau escoramento das fồmas ou possíveis recalques do leito que recebem as escoras.

Estes movimentos podem ser causados pelo projeto mal elaborado nessa fase ou inexistência desse ficando a cargo dos executores da obra, pela deformação das fồrmas devido à umidade ou perda da fixação (pregos, garfos, etc.), devido o uso excessivo das fôrmas ou ainda pelo uso impróprio ou excessivo dos vibradores. As conseqüências desses fatores a serem evitados são visualizados mais facilmente nas Figuras 17 e 18 abaixo.

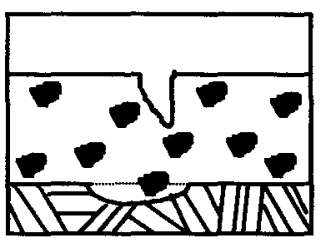

FIGURA 17 - Fissura por movimentação da fundação ou fôrma

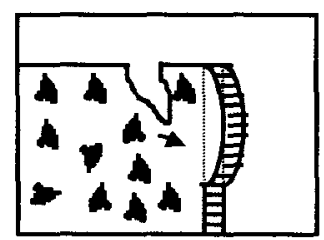

FIGURA 18 - Fissura por movimentos laterais da fôrma 


\subsubsection{2 - Fissuração no estado endurecido}

As fissuras que ocorrem no estado endurecido podem ser resultado de movimentações térmicas, movimentações higroscópicas, atuação de sobrecargas, deformabilidade excessiva da estrutura de concreto armado, recalques de fundação, retração de produtos a base de cimento, alterações químicas dos materiais de construção ou acidentes.

Apesar de CANOVAS (1977) considerar as movimentações térmicas como fissuras no estado plástico há um contra-senso pois RIPPER (1996) e THOMAZ (1989) discorrem sobre o assunto considerando como originadas no estado endurecido.

\subsubsection{2.a - Fissuras por movimentações térmicas}

Conforme THOMAZ (1989), devido às variações sazonais e diárias de temperatura a que as estruturas estão submetidas, ocorrem variações dimensionais dos materiais (dilatação ou retração) que podem ocasionar fissuras.

As fissuras podem surgir também por movimentações diferenciadas sendo que ocorrem principalmente em função:

- dos diferentes coeficientes de dilatação térmica de diferentes materiais unidos e submetidos à mesma temperatura;

- exposição de elementos estruturais a diferentes solicitações térmicas naturais;

- gradientes de temperatura em um mesmo elemento estrutural.

Um fator relevante que merece destaque é que a causa de maior incidência de fissuras em paredes estruturais ou não são as grandes diferenças de movimentações entre as superficies externa e interna das lajes de cobertura. Isso ocorre porque as superficies externas são submetidas à ação direta do sol que podem chegar a temperatura de até $80^{\circ} \mathrm{C}$, e altas variações de temperatura (altas durante o dia e baixas ao cair da noite) que originam movimentações mais bruscas e de maior intensidade.

Apesar das movimentações serem grandes causadoras de fissuras, elas raramente causam danos estruturais. As regiões mais solicitadas são encontros de vigas, ocorrendo fissuras internas. Porém sua movimentação térmica pode gerar fissuras ligeiramente inclinadas nas extremidades dos pilares. Essa incidência é muito freqüente pela inexistência de juntas de dilatação ou pela sua má concepção no projeto. 
Outro caso proveniente de movimentações térmicas são as fissuras causadas pelo rápido resfriamento do concreto após a cura térmica. 0 concreto sofre uma retração resultando em fissuras devido às baixas resistências do concreto ainda novo.

\subsubsection{2.b - Fissuras por movimentações higroscópicas}

0 mecanismo de surgimento de fissuras é similar às por movimentações térmicas sendo a diferença básica as movimentações aqui serem por variações nos materiais pela umidade.

De acordo com THOMAZ (1989), no concreto ocorrem dois tipos de movimentações. Surge a princípio uma contração por perda da água em excesso na sua fabricação e depois dessa contração inicial, o material fica sujeito a diferentes teores de umidade, apresentando movimentações delimitadas por um tempo, ou seja, mesmo se for possível fazer o material chegar a $100 \%$ de saturação, ele nunca retornará ao volume inicial.

As trincas oriundas das variações de umidade são muito parecidas às que ocorrem por variações de temperatura.

Nas peças estruturais, as fissuras e trincas se apresentam sob a aparência liniforme e vertical nos meios dos vãos ou inclinadas nos apoios. Elas ocorrem devido a expansão das paredes de fechamento solicitando o concreto à tração.

\subsubsection{2.c - Fissuras pela atuação de sobrecargas}

Sobrecargas previstas ou não em projeto geralmente são grandes causadoras de fissuras em lajes, vigas, pilares, paredes e vigas parede.

Esse processo de fissuração provoca um rearranjo das tensões no local da fissuração para o resto do elemento estrutural e mesmo nas suas imediações, fazendo com que as solicitações externas sejam absorvidas.

Segundo GIONGO \& SILVA (1994), as fissuras devidas às tensões, causadas pelas solicitaç̃̃es produzidas pela ação do carregamento, ocorrem, evidentemente, somente em zonas tracionadas. De acordo com o tipo de solicitação, encontra-se:

- fissuras de separação: atribuídas à tração simples ou tração de pequena excentricidade. 
- fissuras de flexão: devido à tensão de tração da flexão, aparecem normais às armaduras de flexão sendo praticamente no terço médio do vão.

- fissuras de cisalhamento: atribuídas ao esforço cortante oriundo da flexão ou torção, apresentem-se inclinadas em relação ao eixo da peça.

Apesar do cálculo das estruturas de concreto geralmente estar dentro dos parâmetros dos estados limites de fissuração, a grande preocupação é garantir que as fissuras que surjam estejam dentro das aberturas limites impostas pela Norma Projeto e Execução de Obras de Concreto Armado NBR-6118 não devendo ultrapassar os valores de:

- $0,10 \mathrm{~mm}$ para peças não protegidas, em meio agressivo;

- $0,20 \mathrm{~mm}$ para peças não protegidas, em meio não agressivo;

- $0,30 \mathrm{~mm}$ para peças protegidas.

Segundo THOMAZ (1989), as configurações típicas das fissuras nos elementos estruturais geralmente apresentam aberturas reduzidas e variam de acordo com a solicitação atuante.

Como o concreto tem pouca resistência à tração, as fissuras apresentam aberturas maiores na face inferior da viga, onde as fibras são tracionadas.

Geralmente nos apoios essas fissuras estão a aproximadamente $45^{\circ}$, porém essa configuração como a quantidade e abertura dependem da geometria da peça, pois, em vigas altas essas fissuras podem chegara inclinações próximas a $60^{\circ}$.

Para vigas com deficiência na armadura de cisalhamento ou má ancoragem, as fissuras surgem na região dos apoios na forma inclinada.

Para as vigas atirantadas ou altas, as fissuras caminham para as fibras mais tracionadas podendo-se fazer uma analogia às raízes de uma árvore onde a fissura de flexão no meio do vão apresenta-se praticamente vertical (caule) e próxima a face inferior ramifica-se com aberturas muito inferiores à fissura mãe (raízes).

Já nas vigas calculadas como superarmadas (estádio $\Pi$ /domínio 4), ou seja, hipótese de cálculo caracterizada pela deformação do concreto em $\varepsilon_{\mathrm{c}}=0,35 \%$ e deformação da armadura entre 0 e $\varepsilon_{y d}$, resulta na linha neutra próxima ao banzo tracionado caracterizando portanto, uma estrutura frágil, cujo concreto esmaga 
bruscamente estando com isso a estrutura sujeita à ruína não avisada. Nesse caso, surgem fissuras no banzo superior da viga.

A mesma configuração de fissuras pode ocorre no caso de vigas confeccionados com concreto de baixa resistência.

O descimbramento prematuro e um carregamento precoce da estrutura são causas possíveis e até freqüentes das conseqüentes fissuras de flexão que podem ser encontradas nos elementos estruturais.

Vigas de borda, junto aos cantos de construções, submetidas a excessiva deformabilidade das lajes ou vigas contíguas transversalmente, atuação de cargas excêntricas ou ainda por recalques diferenciais de fundação, são grandes candidatas à fissuras e trincas de torção.

Apesar de não serem freqüentes em elementos estruturais de concreto armado, elas se manifestam através de fissuras a $45^{\circ}$ inclinadas na direção dos apoios e aparecem em ambas faces laterais das vigas com o sentido reverso.

As fissuras nas lajes dependerão de suas caracteristicas geométricas, bem como suas hipóteses de vinculação de borda.

Nas lajes maciças e com grandes vãos, os momentos volventes se manifestam nos cantos das lajes permitindo a aparição de fissuras inclinadas que darão a forma de um triângulo nos cantos sendo as fissuras a hipotenusa dessa figura geométrica.

A inexistência ou deficiência de armadura prevista para resistir aos momentos negativos a que uma laje contínua possa ser submetida é rapidamente detectada através do surgimento de fissuras na face superior desta de forma paralela e sobre os apoios dos tramos contínuos das lajes.

Fissuras em pilares com o concreto endurecido são mais raras de acontecer, porém, quando essas ocorrem, geralmente são por erros construtivos que podem consequentemente gerar fissuras por esmagamento do concreto, muito observado nos pés de pilares.

No caso de flexocompressão dos pilares, podem surgir fissuras levemente inclinadas ou horizontais no seu corpo. 


\subsubsection{2.d - Fissuras por deformabilidade excessiva das estruturas de} concreto armado

De acordo com THOMAZ (1989) não se tem observado grandes problemas quanto às deformações por solicitações de compressão, cisalhamento ou torção. No entanto, as flechas em elementos estruturais fletidos têm causado grandes e graves problemas aos edificios, verificando-se, devido as deformações, caixilhos com problemas de funcionamento, acúmulo de água em vigas-calha ou lajes de cobertura, destacamento de piso e trincas em paredes.

Apesar de ser admissível uma flecha nos elementos estruturais de concreto armado, muitas vezes estas não são compatíveis com o resto dos elementos constituintes do edificio, pois além delas, deve-se levar em consideração a deformação lenta do concreto que junto com a flecha admissível não deverá ultrapassar os parâmetros do estado de deformação excessiva.

Os componentes de um edificio que são mais suscetíveis às deformações são as alvenarias devido à flexão de vigas e lajes.

THOMAZ (1989) menciona que um tipo de fissuração muito observado pela falta de rigidez da estrutura é aquela observada em balanços de vigas, onde o balanço é usado para aliviar os momento positivos. Pela Estática das Estruturas, sabe-se que essa viga em balanço sofre uma deflexão que acarretará no aparecimento de fissuras de cisalhamento na alvenaria e / ou destacamento entre a parede e a estrutura.

\subsubsection{2.e - Fissuras por recalques de fundação}

Todos os solos quando estão submetidos a cargas externas se deformam. No caso dessas cargas serem diferentes ao longo da fundação de uma obra, grandes tensões serão introduzidas na estrutura da mesma, podendo surgir fissuras ou trincas.

Segundo THOMAZ (1989), “de maneira geral, as fissuras provocadas por recalques diferenciados são inclinadas confundindo-se as vezes com as fissuras provocadas por deflexão dos componentes estruturais".

Porém, as fissuras por recalques diferenciados são mais largas, indicando onde ocorreu o maior recalque pois elas seguem na direção dele. Outra característica dessas fissuras é o esmagamento localizado, em forma de escamas, dando indícios das tensões de 
cisalhamento que as provocaram e, finalmente, quando os recalques são acentuados, pode ser observado uma nítida variação na abertura da fissura.

Alguns dos fatores que geram o recalque diferencial (Figura 19) são: a consolidação distinta do aterro carregado (a), fundações assentadas sobre seções de corte e aterro (b), recalques em construções menores que são vizinhas de construções maiores devido a interferência do bulbo de tensões (c), falta de homogeneidade do solo (d) e rebaixamento do lençol freático (e).

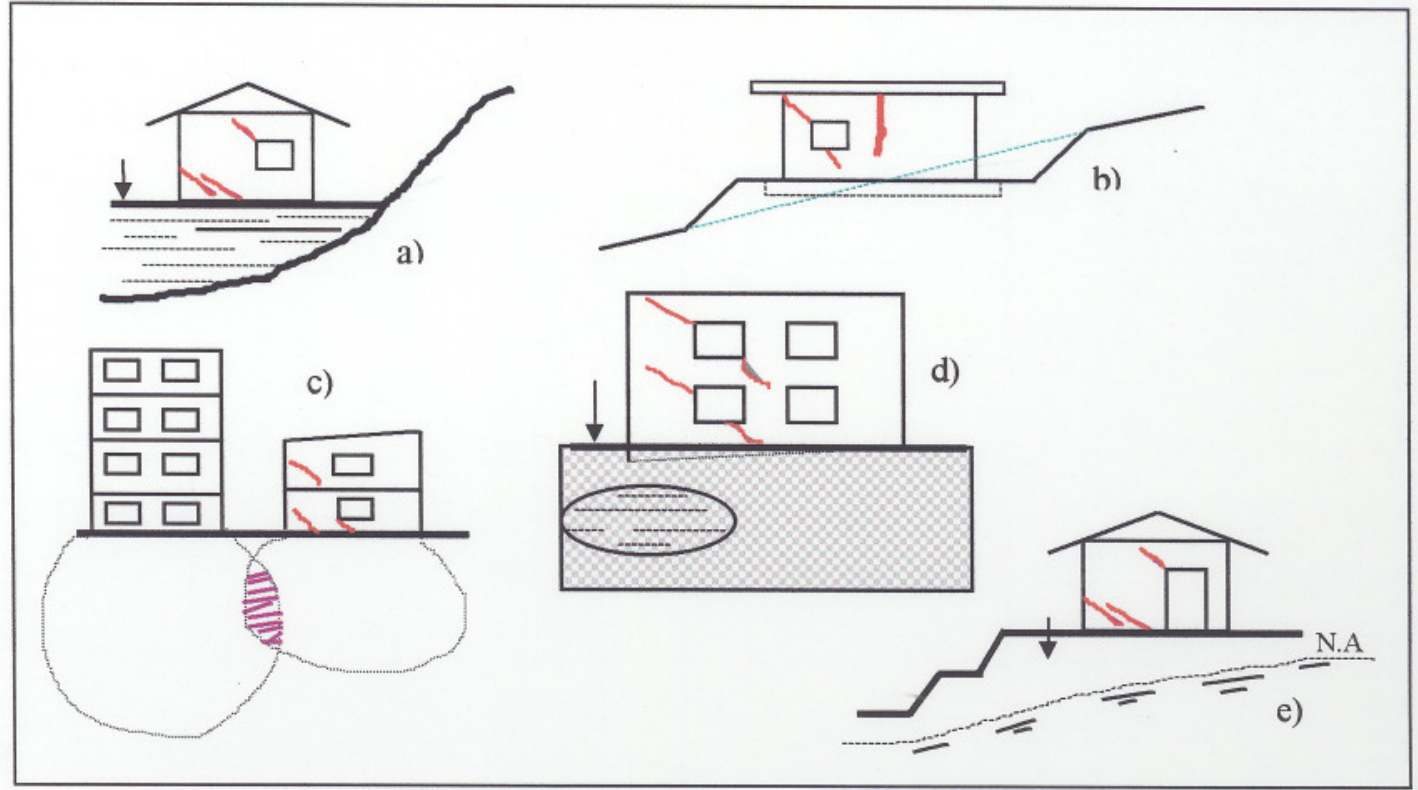

FIGURA 19 - Fissuras típicas de recalques diferenciais (fonte: Trincas em Edifícios: Ercio Thomaz, Pini/1989)

Como regra, é bom sempre ter em mente que as aberturas das fissuras provocadas por recalque são diretamente proporcionais à sua intensidade.

\subsubsection{2.f - Fissuras por retração de produtos a base de cimento}

Em uma mistura para se confeccionar um concreto a relação água/cimento necessária para a total hidratação do cimento é por volta de 0,25 a 0,30.

O que geralmente acontece é que devido as necessidades de trabalhabilidade que a obra em questão necessite é comum adicionar mais água à mistura que resulta na acentuação da retração. 
Os três tipos de retração que ocorrem em um produto feito com cimento são a retração química, retração de secagem e retração por carbonatação e ocorrem com o produto endurecido ou em processo de endurecimento.

Alguns dos fatores que intervêm na retração dos produtos feitos com cimento são a composição química e finura do cimento, quantidade de cimento adicionada à mistura, natureza e granulometria do agregado, quantidade de água na mistura, condições de cura e umidade relativa do ar.

As estruturas de concreto são vulneráveis a grandes tensões de retração. Nas estruturas em pórtico, as vigas superiores sofrem grande retração transmitindo grandes tensões aos pilares mais extremos que por sua vez apresentarão fissuras horizontais.

As fissuras de retração em uma viga depende da dosagem, do adensamento e da cura do concreto .

Em vigas altas, que não tenham ou deixem de apresentar armadura de pele suficiente, surgirão fissuras paralelas e verticais aproximadamente no meio da sua altura útil.

A retração das lajes pode gerar compressão de pisos cerâmicos ou ainda a retração do concreto pode gerar fissuras na própria laje com configuração mapeada e regular.

É comum observar fissuras nas faces de elementos estruturais, e, em especial, nas vigas, devido o enfraquecimento das seções causados pela presença de tubulações embutidas.

\subsubsection{2.g - Fissuras por concentração de esforços}

É comum o aparecimento de fissuras também devido à forma do elemento estrutural pois existem peças com os chamados "cantos vivos" que ocasiona uma concentração de esforços nesses pontos gerando fissuras locais. Além dessas peças com cantos vivos é comum também aparecer esse tipo de fissuras nas peças onde ocorre mudança na direção das armaduras. 


\subsection{2 - DESAGREGAÇÃO}

Um dos sintomas mais característicos da existência de ataque químico é a desagregação.

É com o fenômeno da desagregação que o cimento que incorpora um concreto perde seu carater conglomerante. Com isso os agregados passam a ficar livres e soltos da pasta.

O fenômeno tem início na superficie do concreto com uma mudança de coloração seguido do aumento da espessura das fissuras entrecruzadas e finalmente a desintegração da massa do concreto.

Como consequência da desagregação, os materiais componentes perdem a coesão ao destruir-se perdendo portanto suas características mecânicas.

Alguns autores colocam que as prováveis causas da desagregação podem ser a ação dos sulfatos e dos cloretos, pois se os concretos forem fabricados com cimentos não adequados, com o passar do tempo de exposição estes começarão a apresentar sinais dessa enfermidade.

A melhor prevenção para se evitar esse fenômeno é se produzir um concreto muito compacto e com um cimento adequado ao meio que será inserido.

No caso do meio ser muito agressivo, o concreto deverá tomar cuidados acima $\mathrm{e}$ incrementar essas medidas com o emprego de barreiras impermeáveis protetoras para evitar o contato do concreto com o meio.

\subsection{3 - EFEITO PAREDE}

Segundo HELENE (1986) por efeito parede entende-se a movimentação de argamassa para junto das superficies contínuas que restringem o concreto, tais como fồmas e armaduras. Essa movimentação se dá à custa do empobrecimento da massa do interior do concreto.

Peças com alta densidade de armadura, onde a relação superficie/volume seja elevada, tendem a apresentar trechos com vazios ou pelo menos com baixos teores de argamassa porque esta concentrou-se ao longo de uma superficie. 
Com efeito, a parede ou superficie limite influi na compacidade, pois a quantidade de argamassa necessária para encher o espaço entre as partículas maiores do inerte e a parede é maior do que no interior da massa, e, portanto, é preciso prever excesso de argamassa no concreto sujeito a estas condições, que estaria bem proporcionado para massa indefinida. Este excesso é tanto mais acusado quanto maior for a relação entre a superficie da peça e seu volume.

Fatores como alta taxa de armadura e principalmente a ausência de espaçadores podem ser apontados como os maiores causadores do efeito parede (Figura 20).

A melhor forma de evitar esse efeito é preparar um concreto mais argamassado ou lançar uma camada inicial só de argamassa (igual à do concreto) antes do concreto normal, a fim de preencher a camada entre as superficies das fôrmas e as armaduras.

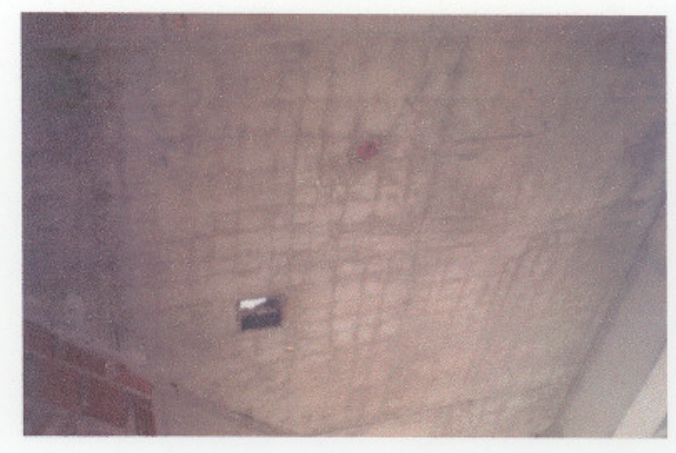

FIGURA 20 - Foto registrando efeito parede em laje maciça de concreto armado.

\subsection{4 - DISGREGAÇÃO}

A disgregação caracteriza-se pela ruptura do concreto em geral nas regiões salientes das peças. Geralmente as disgregações originam-se por esforços internos que resultam em fortes tensões de tração que o concreto não tem condições de resistir. Quando essa tensão de tração é maior que a tensão de ruptura esse material fissura podendo provocar a expulsão do concreto que haja entre essas fissuras.

Um dos motivos mais freqüentes e importantes que causam as disgregações é a corrosão das armaduras (Figura 21). A camada expansiva de óxido que é produzido pela reação da corrosão gera grandes tensões no concreto que acaba se soltando nessas regiões onde se encontram as barras de aço. 


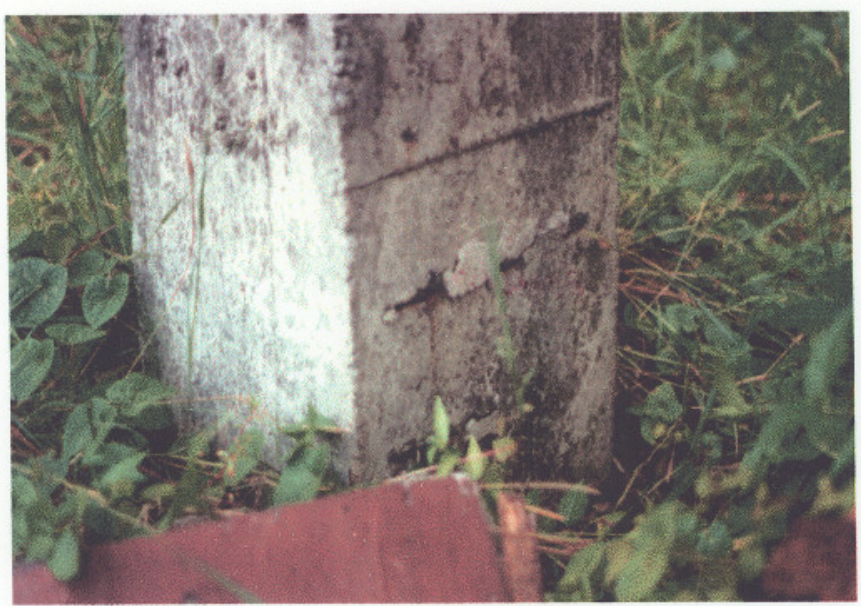

FIGURA 21 -

Foto de disgregação ocasionada por corrosão da armadura no pé de pilar

Outro motivo que pode gerar as disgregações são as fortes tensões que surgem devido a cargas excessivas que resultaram em grandes deformações nos elementos estruturais.

É importante mencionar que o concreto disgregado é um concreto sadio que simplesmente se solta do corpo por ser incapaz de resistir a tensões muito superiores a ele.

\subsection{5 - CORROSÃO DA ARMADURA}

O dano ao concreto resultante da corrosão da armadura se manifesta na forma de expansão, fissuração e finalmente o lascamento do cobrimento do concreto.

Além da perda do cobrimento, pode ocorrer a perda da aderência entre o concreto e o aço e a diminuição da área da seção transversal da armadura, ocasionando até o colapso da estrutura (Figura 22).

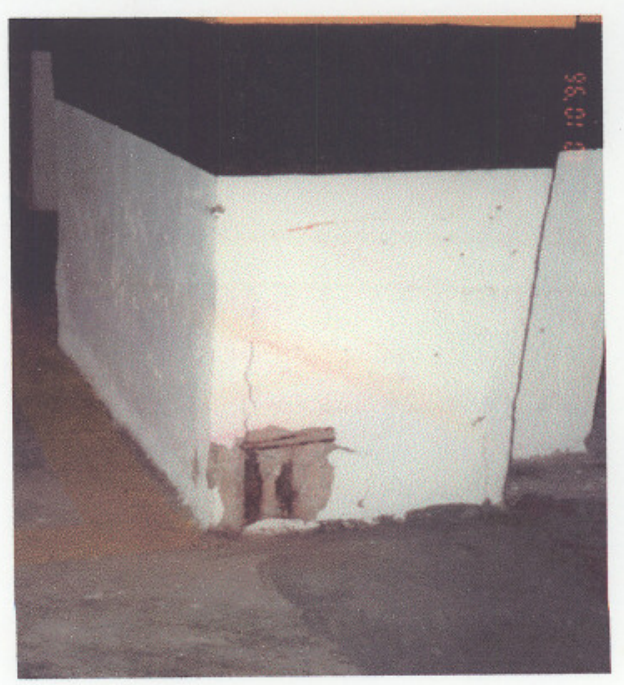

FIGURA 22 - Foto registrando fissuras causadas por expansão e corrosão da armadura no pé do pilar. 
HELENE \& FIGUEIREDO (1994) descrevem que a armadura se encontra normalmente protegida da corrosão devido à alta alcalinidade do concreto que envolve a película protetora do aço. A essa proteção dá-se o nome de passivação do aço.

Porém, existem duas possibilidades desse concreto perder sua alcalinidade: quando esse fica sob a ação do ácido carbônico ou submetido à presença dos íons cloreto $\left(\mathrm{Cl}^{-}\right)$.

Quando ocorre uma dessas duas reações acima, a película com função passivadora do aço é rompida, tornando o aço vulnerável (despassivação do aço) ao processo de corrosão.

Os íons cloreto podem penetrar no concreto por difusão, impregnação ou absorção capilar de águas contendo teores de cloreto que ao superarem, na solução dos poros de concreto, um certo limite em relação à concentração de hidroxilas (redução do $\mathrm{pH}$ ), despassivam a superficie do aço e instalam a corrosão.

Outros gases de natureza ácida $\left(\mathrm{SO}_{2}\right.$ e $\left.\mathrm{H}_{2} \mathrm{~S}\right)$ presentes em atmosferas urbanas e industriais também podem desencadear a despassivação conforme mencionado no item 2.4.1.2.b.

\subsection{6 - NINHOS DE CONCRETAGEM (BICHEIRAS)}

Caracterizam-se pela ausência de concreto em determinadas regióes da peça concretada.

É comum confundir bicheira com segregação. Porém são diferentes, pois a segregação surge pelo mal planejamento da concretagem (por exemplo, lançamento do concreto de altura inadequada, concreto excessivamente plástico) ocasionando uma separação entre a argamassa e os agregados. A diferença está exatamente nesse ponto pois as bicheiras podem surgir por mal adensamento, altas taxas de armadura (pé de pilar, por exemplo) ou por incompatibilidade de dimensão do agregado graúdo, impedindo a passagem do concreto entre determinadas regiões resultando em espaços sem preenchimento não só de pasta mas também do agregado graúdo surgindo "buracos" ao longo da peça. 


\subsection{7 - EFLORÊSCENCIAS}

Eflorescência é geralmente entendida como o depósito de sais por cristalização na superficie exterior dos elementos, sendo que esses sais são provenientes dos materiais constituintes de tais elementos através da dissolução em água (proveniente de chuva, umidade relativa do ar, etc.). A água carrega partículas interiores do concreto "lavando-o" e as deposita na superficie, depois evapora (Figura 23).

Para que ocorra eflorescência é necessário que ocorra três condições:

- existência de sais solúveis em algum material constituinte do elemento;

- a presença de umidade, normalmente infiltrada, que tende a sair para o exterior por simples diferença de pressão e vapor;

- dissolução e transporte dos sais até a superfície exterior do elemento onde, ao evaporar a água em contato com uma atmosfera com menor pressão de vapor, os sais dissolvidos recristalizam-se adotando formas que, segundo a literatura, se assemelham a flores, de onde vem o nome de eflorescência.

O sulfato cálcico $\left(\mathrm{Ca}_{2} \mathrm{SO}_{4}\right)$ é uma das eflorescências mais comuns em concretos e se trata de uma patologia comumente confundida com erosões químicas. Não se trata de um sal facilmente solúvel, exceto em presença de outros sais como o sulfato potássico, ou em períodos de prolongada umidade. Seus cristais têm uma corrosão esbranquiçada.

$\mathrm{O}$ carbonato de cálcio $\left(\mathrm{CaCO}_{3}\right)$ também pode resultar de eflorescência em materiais de origem calcária. Embora apareça como consequência da reação entre o hidróxido de cálcio que o concreto libera durante a pega e o anidrido carbônico do próprio ar ao chegar o hidróxido ao exterior.

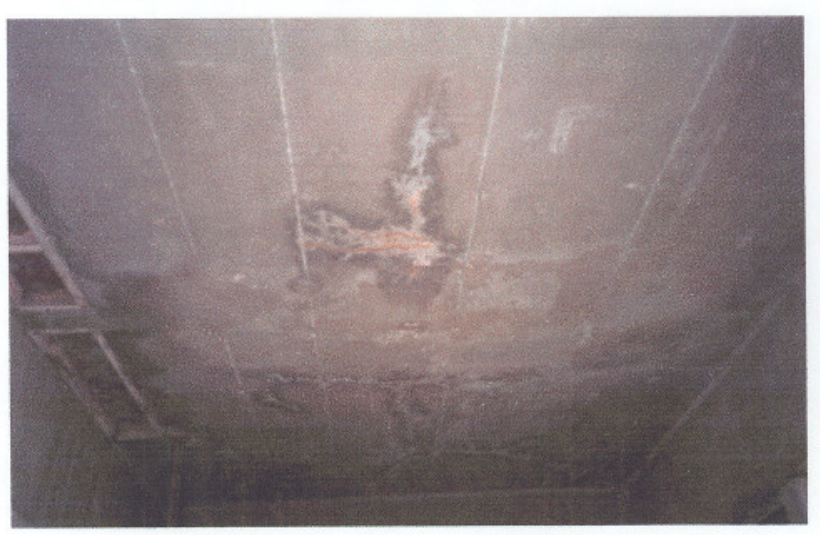

FIGURA 23 - Foto de eflorescências em laje maciça seguidas de lixiviação e carbonatação. 


\subsection{8 - SEGREGAÇÃO}

É conhecida também como ninhos de concretagem ou "bicheiras", porém são questões diferentes como já explicado no item 3.8.6. Consiste na falta de uniformidade do concreto, apresentando aglomeração de agregado graúdo sem o envolvimento da argamassa que resulta em superficies com o agregado aparente (Figura 24).

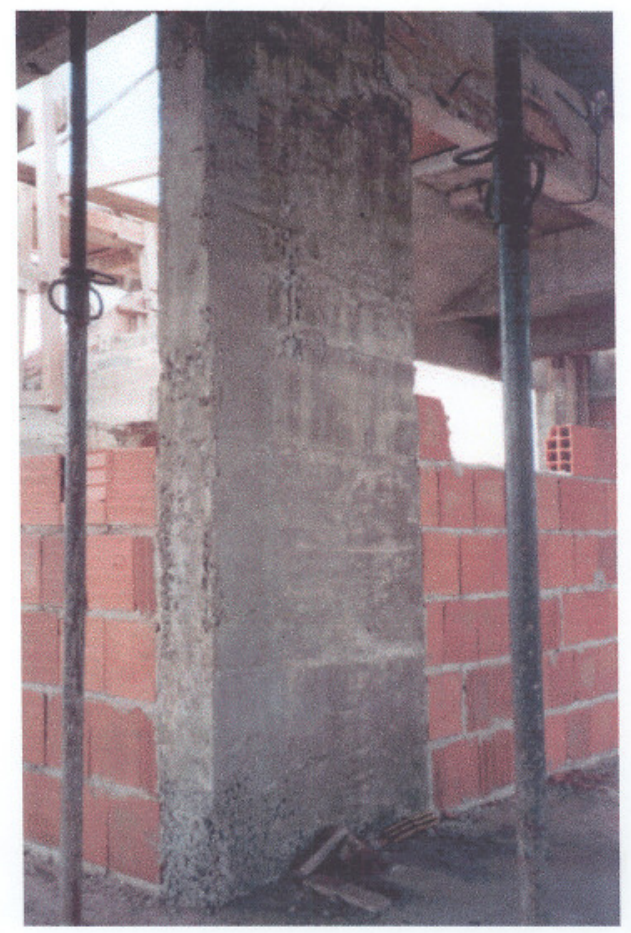

FIGURA 24 - Foto registrando segregações do concreto por toda extensão do pilar.

Nota-se com facilidade a falta de homogeneidade na superficie do concreto; os agregados maiores se agrupam sem a presença de argamassa para preencher os espaços entre eles. Porém, quando o mesmo ocorre no seu interior é preciso observar se existe descaracterização considerável da região suspeita; isso pode ocorrer depois que a edificação entra sem serviço e a região onde existe segregação ou o vazio começa a trabalhar à compressão, provocando maior deformação. Dependendo da extensão dessa lesão, a estrutura pode ser levada à ruptura.

\subsection{9 - CARBONATAÇÃO}

$\mathrm{O}$ monóxido e o dióxido de carbono, $\mathrm{CO}$ e $\mathrm{CO}_{2}$, gases ácidos presentes na atmosfera, reagem com a portlandita, $\left(\mathrm{Ca}(\mathrm{OH})_{2}\right)$ presente nos poros e superficies do 
concreto formando um sal, o carbonato de cálcio, $\mathrm{CaCO}_{3}$, que é um produto insolúvel, e libera água

$$
\mathrm{Ca}(\mathrm{OH})_{2}+\mathrm{CO}_{2} \Rightarrow \mathrm{CaCO}_{3}+\mathrm{H}_{2} \mathrm{O}
$$

Essa reação se dá, preponderantemente, com umidade relativa do ambiente de $60 \%$ a $85 \%$ o que faz com que esse fenômeno seja inerente à maioria das estruturas de concreto.

Caso haja excesso de $\mathrm{CO}_{2}$ na água o $\mathrm{CaCO}_{3}$ junta-se com o $\mathrm{CO}_{2}$ livre e a água e transforma-se em bicarbonato de cálcio, que é um produto solúvel, podendo ocorrer dissolução do hidróxido de cálcio da pasta de cimento, porém essa reação é reversível.

O dióxido de carbono ocorre, mesmo em situações de meio ambiente rural, onde seu teor é de aproximadamente de $0,03 \%$. Em situações muito especiais, ainda nesse meio ambiente, pode atingir concentrações de $1 \%$.

A delimitação de uma região carbonatada e outra isenta de carbonatação é influenciada pelos vazios e pelas partículas dos agregados.

Esse processo se dá com o abaixamento do $\mathrm{pH}$ da região alcalina que protege a armadura, para níveis em torno de 8,5 a 9,0.

Essa situação cria condições que podem proporcionar a inicialização de um processo corrosivo da armadura, propagando-se em todo o substrato.

De acordo com HELENE(1993), os mecanismos de transporte envolvidos são a absorção, a permeabilidade, a difusão e a migração.

\subsubsection{0 - LIXIVIAÇÃo}

Por lixiviação entende-se a ação de águas ácidas e moles sobre o concreto. Essas águas são capazes de dissolver a pasta de cimento, carreando os compostos hidratados e reduzindo o $\mathrm{pH}$ da superficie.

Ocorre, então, um duplo ataque: à pasta de cimento, que é dissolvida, e a armadura que é despassivada.

Enquadram-se, também nesse mecanismo, o efeito das chuvas ácidas sobre as superficies de concreto, com conseqüente redução de $\mathrm{pH}$. 


\section{9 - O PANORAMA PATOLÓGICO NO BRASIL E NO MUNDO}

A Patologia hoje vem sendo encarada de uma forma muito séria. Na Europa existem grandes centros de pesquisa que se dedicam aos estudos das manifestações patológicas que ocorrem em seus países de modo a sempre estarem reciclando seus conhecimentos e inovarem seus métodos de recuperação estrutural.

Um desses centros que ocupa lugar de destaque é o Instituto Eduardo Torroja (Espanha) que foi o precursor no curso de Patologia das Construções iniciado em 1976.

Os conceitos de Patologia começaram a ser difundidos no país a partir de 1977 com o Prof. Dr. Paulo Roberto Lago Helene que integrou a primeira turma do curso nesse Instituto.

Em 1985, na Escola de Engenharia de São Carlos, da USP, João Bento de Hanai e Jefferson B. L. Libório, iniciaram as pesquisas sobre o "Estudo Patológico das Construções de Argamassa Armada Existentes no Brasil".

Em 1987, divulga-se uma pesquisa abrangente sobre a situação patológica envolvendo diversos países europeus. As estatísticas dessa pesquisa desvendaram quais as causas mais comuns de surgirem as patologias, conseguindo associar qual fase da vida de uma construção apresenta maiores incidências (Tabela 12) e por fim lista qual o tipo de manifestação de maior incidência para os países participantes da pesquisa (Tabela 13).

TABELA 12 - Origem das patologias em países europeus (FONTE - Carmona Filho \& Marega)

\begin{tabular}{ccccc}
\hline \multicolumn{5}{c}{ Causas $(\%)$} \\
\hline País & Projeto & Materiais & Execução & Uso \\
\hline Inglaterra & 49 & 11 & 29 & 10 \\
\hline Alemanha & 40 & 14 & 29 & 9 \\
\hline Romênia & 40 & 15 & 29 & 10 \\
\hline Bélgica & 46 & 15 & 22 & 8 \\
\hline Dinamarca & 37 & 25 & 22 & 9 \\
\hline Iugoslávia & 34 & 22 & 24 & 12 \\
\hline França & 37 & 5 & 51 & 7 \\
\hline Espanha & 52 & 16 & 39 & 13 \\
\hline
\end{tabular}


TABELA 13 - Quantificação das manifestações em países europeus (FONTE Carmona Filho\& Marega).

\begin{tabular}{cccc}
\hline & \multicolumn{3}{c}{ Tipo de Manifestação (\%) } \\
\hline País & Umidade & Fissuras & Corrosão \\
\hline Inglaterra & 53 & 17 & 14 \\
\hline Alemanha & - & - & - \\
\hline Romênia & - & - & - \\
\hline Bélgica & 27 & 12 & 16 \\
\hline Dinamarca & - & - & - \\
\hline Iugoslávia & - & - & - \\
\hline França & 18 & 59 & 12 \\
\hline Espanha & 8 & 59 & 11 \\
\hline
\end{tabular}

No Brasil, CARMONA FILHO \& MAREGA (1988) divulgaram um estatística semelhante retratando os problemas ocorridos no país.

Foram analisados 709 casos e a partir daí detectou-se a fase a qual é mais comum a origem dos problemas (Figura 25) e, dando continuidade e complementando a pesquisa, quantificou-se as incidências mais observadas (Figura26).

\section{Incidências dos problemas por suas origens}

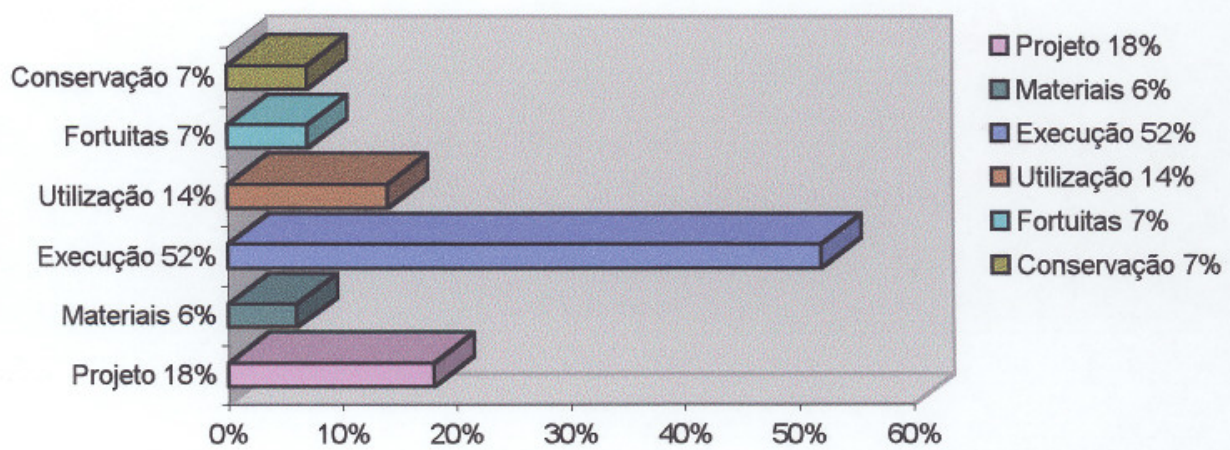

FIGURA 25 - Avaliação das incidências segundo sua origem (FONTE - Carmona Filho \& Marega - 1988). 


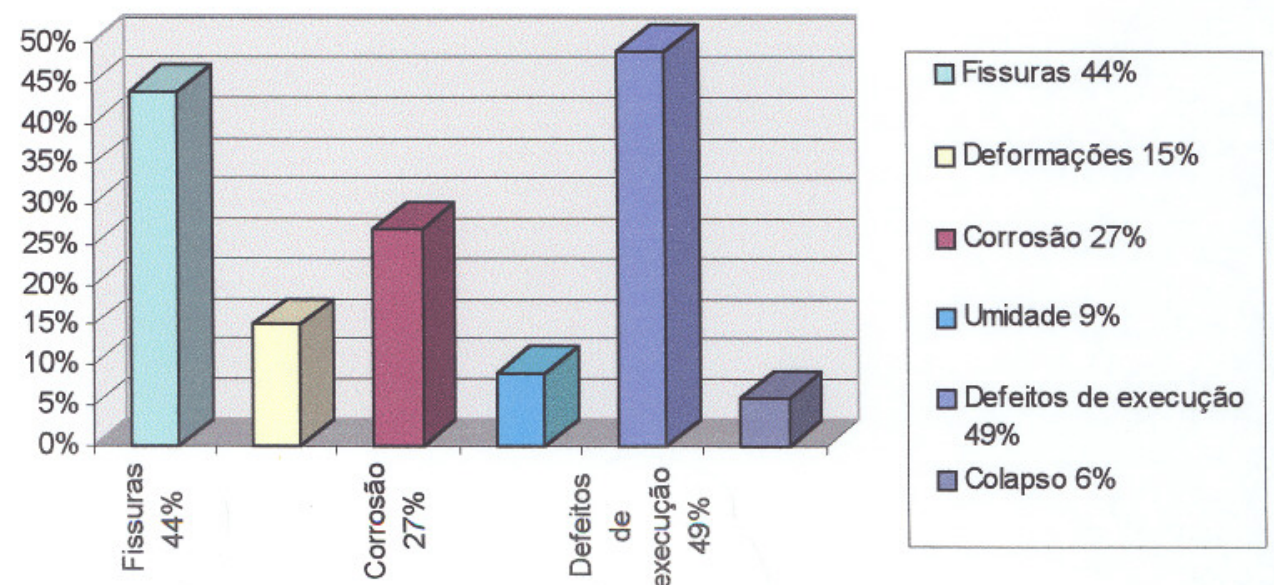

FIGURA 26 - Quantificação das incidências mais observadas (FONTE: Carmona Filho \& Marega - 1988).

A autora, a fim de elaborar estatísticas semelhantes às pesquisas apresentadas anteriormente, estudou a situação patológica da cidade de São Paulo, a partir do levantamento de dados de obras assistidas por três empresas de recuperação estrutural situadas na cidade.

Foram analisadas um total de 155 obras abrangendo edificios comerciais, residenciais e industriais, pontes, viadutos, galerias de água, barragem e cais.

Ao final do levantamento, surpreendemente, ao observar a origem dos problemas, a falta de manutenção liderou com $52 \%$, seguidos de problemas de execução com $47 \%$ e projeto com $32 \%$, como pode-se observar na Figura 27.

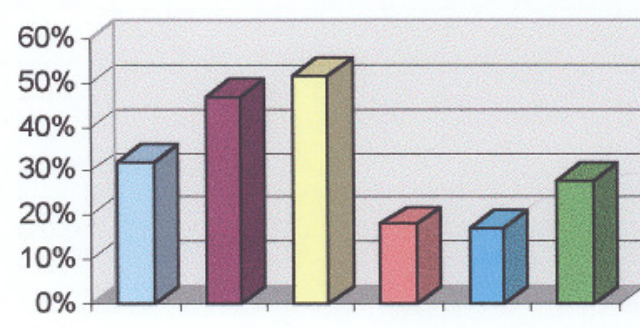

$\square$ Projeto $32 \%$

口Execução $47 \%$

$\square$ Falta de Manutenção $52 \%$

$\square$ Manutenção Inadequada $16 \%$

口Uso Inadequado $17 \%$

口 Mudança de Uso $28 \%$

FIGURA 27 - Origem dos problemas patológicos na cidade de São Paulo. 
Ao se distribuir estatisticamente os tipos de problemas ocorridos, a falta de cobrimento disparou com $47 \%$ e é seguido pela carbonatação com $37 \%$ como visto na Figura 28.

Apesar da corrosão das armaduras estar em quarto lugar na lista das incidências observadas, é interessante observar e ressaltar que os dois primeiros colocados na listagem são considerados os primeiros sintomas para desencadear o processo da corrosão.

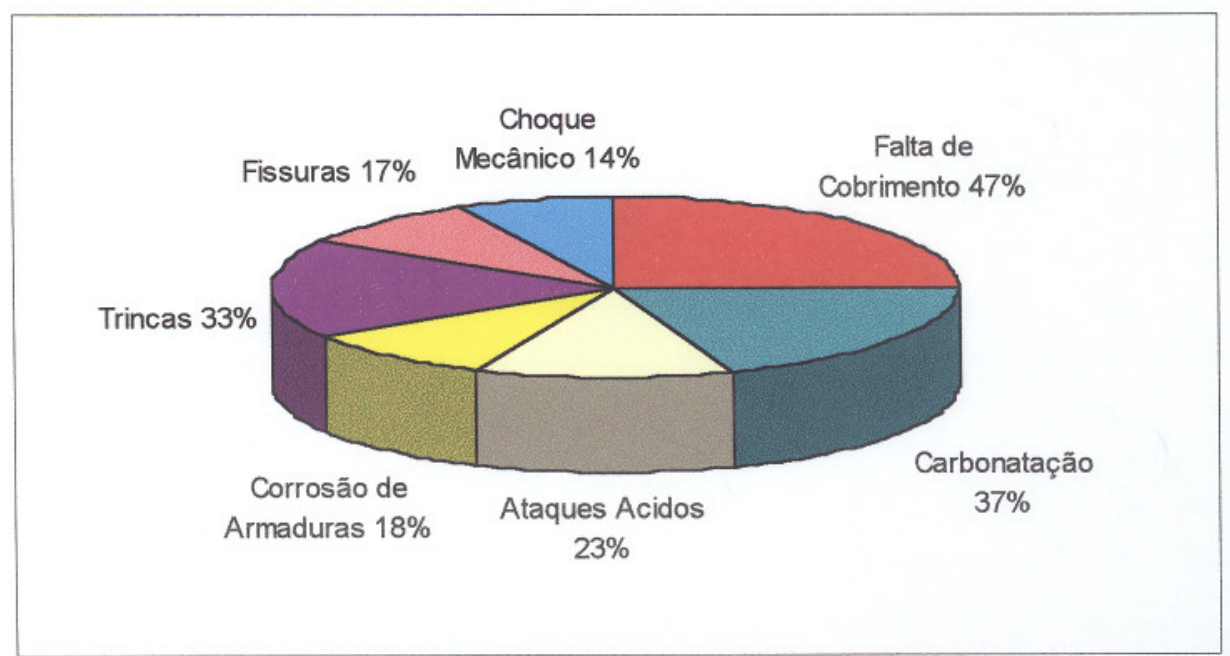

FIGURA 28 - Distribuição dos tipos de problema observados na cidade de São

Paulo.

DAL MOLIN \& ANDRADE (1996) realizaram estudos semelhantes para as estruturas de concreto armado no Estado de Pernambuco.

Como pode-se observar na Figura 29, a corrosão das armaduras lidera as estatísticas com $61 \%$.

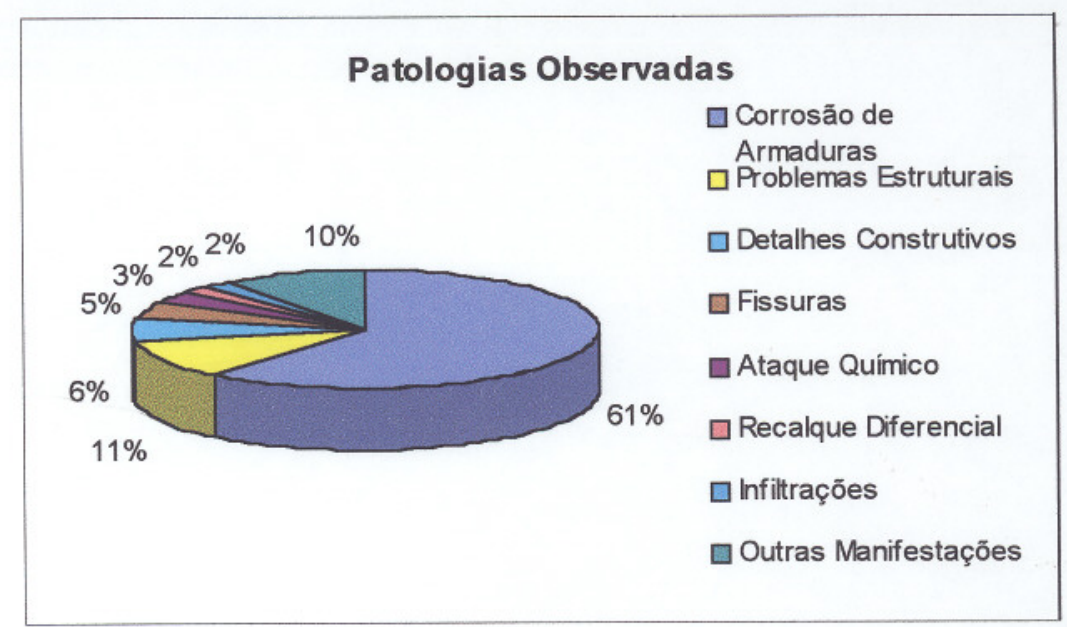

FIGURA 29 - Distribuição dos tipos de problema observados na região Nordeste do país (FONTE: Dal Molin \& Andrade, 1996). 
Esse número se justifica pelo fato das obras estarem próximas a beira mar, locadas em região salina, e confirma, segundo a literatura, a influência da atmosfera marinha considerada de alto grau de agressividade para o concreto.

O mesmo estudo foi realizado por DAL MOLIN \& ANDRADE (1994) para a região Amazônica. ${ }^{2}$

Quanto às origens dos problemas, planejamento/projeto e execução acumularam $68,75 \%$, má utilização em seguida com $25,86 \%$ e com baixa incidência ficaram os danos devido aos materiais.

Nas principais incidências patológicas em estruturas de concreto armado, a corrosão volta a despontar como pode ser visto na Figura 30.

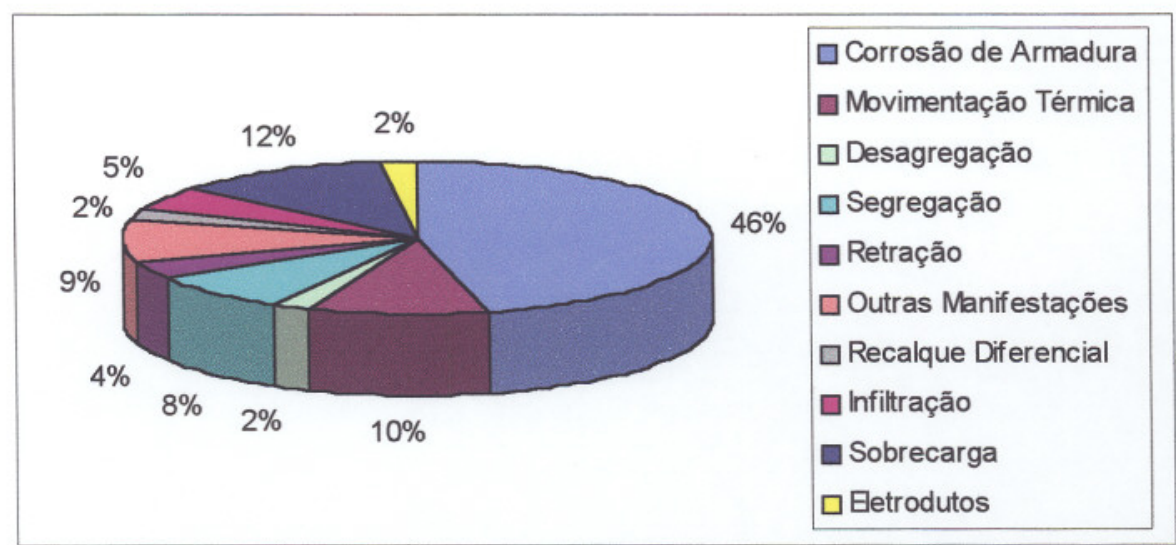

FIGURA 30 - Distribuição dos tipos de problema observados na região Amazônica do país (FONTE: Dal Molin \& Andrade, 1994).

Finalmente, DAL MOLIN (1988) realizou o mesmo estudo patológico para as edificações do Rio Grande do Sul, restringindo-se, porém, às fissuras em estruturas de concreto armado.

A autora classificou-as em três categorias: fissuras sem gravidade, fissuras de moderada gravidade e fissuras graves.

$\mathrm{Na}$ categoria das fissuras sem gravidade as fissuras causadas por existência de eletrodutos se destaca com $39,13 \%$ seguidas das fissuras por movimentações térmicas com $33,70 \%$ e fissuras de retração por secagem com $17,39 \%$.

\footnotetext{
${ }^{2}$ Região Amazônica - sempre referente à Amazônia Legal que compreende os estados da Região Norte ( Acre, Amapá, Amazonas, Pará, Rondônia, Roraima e Tocantins), da Região Nordeste ( parte do estado do Maranhão) e Região Centro Oeste (parte do estado do Mato Grosso)
} 
Nas fissuras moderadas, as movimentações térmicas tomaram a frente com $44,54 \%$.

Finalmente as classificadas fissuras graves tiveram as por corrosão por armadura o maior índice com $40 \%$ das incidências, vindo as por sobrecarga com $30,67 \%$, detalhes construtivos com $13,33 \%$ e fissuras por fundações $10,67 \%$ por ordem de grandeza sendo que as demais apresentaram-se com baixas porcentagens de ocorrência. 


\section{METODOLOGIA ADOTADA NA PRESENTE PESQUISA}

O objeto de estudo se atém às edificações que, segundo a definição do IBGE é o segmento da Indústria da Construção que engloba obras habitacionais, comerciais, industriais, obras do tipo social (escolas, creches e hospitais) e obras destinadas a atividades culturais, esportivas e de lazer. No entanto devido à diversidade do segmento, a pesquisa deteve-se em investigar as possiveis patologias somente nos edificios residenciais e comerciais concebidos em estruturas de concreto armado.

Foram elaborados dois formulários de investigação. O primeiro assumia o papel de um checklist da edificação que era preenchido em entrevistas realizadas com os profissionais responsáveis pelas obras e o segundo formulário foi elaborado com a finalidade de detectar e quantificar em obra os sintomas patológicos observados.

Como parte integrante desse segundo formulário foi elaborado um material suporte que eram os formulários para se listarem de modo organizado em obra as fotografias tiradas dos elementos estruturais em observação.

A idéia de se realizar o checklist nos moldes propostos foi o de desenvolver acima de tudo os sentidos humanos e o de proporcionar o máximo possível, as alternativas estabelecidas em cada projeto; assim, a cada obra visitada, determinado tópico assume importância relativa sobre os demais que não necessariamente se repetem em outros sítios inspecionados.

As entrevistas foram realizadas em edificios em construção e para cada obra preenchia-se um checklist, um formulário de investigação e um formulário fotográfico. $\mathrm{O}$ checklist elaborado consistia das seguintes perguntas:

Identificação:

Nome da edificação:

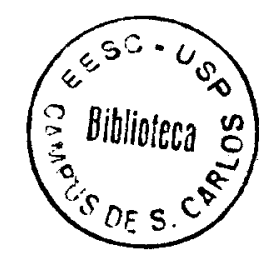


Início da obra:

Construtora:

Contato:

1. Localização da obra :

2. Posicionamento da obra no terreno - situação:

3. Distribuição de repartições (como são os apartamentos?)

4. Estrutura: características geométricas

5. Existe projeto?

5.1. Planta de formas :

5.2. Planta de Armaduras :

6. Diário de obras (existe? É preenchido diariamente?) :

7. Informações técnicas sobre responsáveis - estrutura :

calculista:

projeto arquitetônico:

fundação:

controle tecnológico:

fiscal:

8. Existiu alguma anomalia durante a obra? (mudança de engenheiros, mestre, funcionários, subempreita, etc.)

9. Poluição ambiental. Existe? (ambiente. rural, urbano, marinho, industrial ?) exemplo)

10. Existe alguma região com atmosfera viciada? (umidade excessiva, por

11. Direção predominante dos ventos.

a) carregamento da estrutura

b) transporte de partículas sólidas

c) transporte de gases agressivos

d) água

12. Tipologia da estrutura:

12.1 - Como é composta ?Existem:

- pilares?

- vigas?

- vigas em balanço?:

- vigas-parede?

- lajes:

- Armadas em cruz?

- Armadas em uma direção?

- cogumelo?

- capitéis?

- paredes diafragma?

- paredes?

- lintéis?

- tubulões?

- estacas?

- blocos?

- vigas alavanca?

- etc.

- Descrição da estrutura : 
12.2 - Existe(m) núcleo(s) rígido(s) :

12.3 - Existem elementos de contraventamento na estrutura?

\section{Execução :}

13. Aço :

- Que tipo?

- Bitolas utilizadas:

- Procedência:

- Ocorreu substituição de bitolas em algum instante da obra?

- Existem emendas ? Que tipo ? Por traspasse ou solda? Há dobramentos?

- Onde ficam armazenadas?

- Em alguma fase da obra as barras ficaram armazenadas por muito tempo? Quanto tempo?

- Foi realizado algum tipo de ensaio com as barras?

- Há algum tipo de inspeção das barras antes delas serem utilizadas? (verificação das bitolas, por exemplo).

\section{Fôrmas :}

- Que tipo? (MADEIRA, METÁLICA)

- Descriminar para cada elemento estrutural

14.1 Utiliza-se desmoldante nas fôrmas?

14.2. - Foram utilizados espaçadores, pastilhas, caranguejos, etc?

14.3 - As fồmas aguardam vistoria final do engenheiro para serem liberadas?

14.4 - Existe planejamento ao se empregar as fôrmas?

14.5 - Quantas vezes elas são reaproveitadas?

14.5 - Como são feitas as fôrmas ? São montadas em canteiro ou são do tipo prontas contendo um projeto adequado a obra?

14.6 - Os escoramentos são metálicos ou de madeira?

14.7 - E o cimbramento?

14.8 - Ha algum tipo de planejamento (ordem) ao se retirar os escoramentos das lajes e das vigas?

\section{5 - Materiais utilizados na estrutura:}

15.1 - Concreto usinado ou rodado na obra?

15.2 - Qual é a concreteira?

15.3 - Agregado Miúdo:

- procedência:

- é possível diagnosticar?

- análise. Existe? Quem faz ou fez?

- qualidade?

15.4 - Agregado Graúdo (idem ao agregado miúdo):

15.5 - Água de amassamento (idem ao agregado miúdo):

15.6 - Aglomerante:

- cimento: (tipo, qualidade, fabricante)

- análise. Existe? Quem faz ou fez?

- qualidade?

15.7 - Adições (idem ao agregado miúdo):

15.8 - Aditivos (idem ao agregado miúdo) 
15.7 - Traços utilizados :

16. $-f_{C K}$ empregado (Tabela14):

TABELA 14 - Tabela utilizada na pesquisa em campo para investigação do $\boldsymbol{f}_{\mathrm{ck}}$ empregado.

\begin{tabular}{llllll}
\hline $\begin{array}{l}\text { Elemento } \\
\text { estrutural }\end{array}$ & $\begin{array}{l}\mathbf{f}_{\text {CK }} \\
\text { utilizado }\end{array}$ & $\begin{array}{l}\text { Elemento } \\
\text { estrutural }\end{array}$ & $\begin{array}{l}\mathbf{f}_{\text {CK }} \\
\text { utilizado }\end{array}$ & $\begin{array}{l}\text { Elemento } \\
\text { estrutural }\end{array}$ & $\begin{array}{l}\mathbf{f}_{\text {CK }} \\
\text { utilizado }\end{array}$ \\
\hline pilares & & estacas & & lintéis & \\
\hline vigas & blocos & parede \\
\hline lajes & tubulão & caixa d'água \\
\hline capitéis & & viga-parede & etc. \\
\hline
\end{tabular}

16.3 - Emprega-se vibrador? Qual (s) o(s) tamanho(s) das agulhas empregadas?

16.4 - As fồrmas são molhadas e limpas antes da concretagem?

16.5 - Costuma seguir um horário para as concretagens ou concreta-se em qualquer horário do dia?

17 - Cura :

- Existiu?

- Como é/foi feita?

- Quando começa o processo de cura?

- Quanto tempo?

18 - Equipamentos:

18.1- Quais equipamentos existentes no canteiro?

18.2 - Emprega-se com freqüência vibradores?

19 - Observou-se alguma patologia?

Posteriormente a essa bateria de perguntas a fim de possibilitar uma anamnese, ainda com os profissionais responsáveis pelas obras, buscou-se os projetos da edificação em questão de maneira que ao analisá-los pudessem ser detectadas deficiências como :

- falta de detalhamento ou detalhes mal projetados;

- cargas ou tensões não consideradas no cálculo estrutural;

- variação brusca de seção em elemento estrutural;

- falta de drenagem, ou projeto deficiente de drenagem;

- juntas de dilatação insuficientes, mal projetadas ou mal executadas;

- e efeitos de fluência do concreto não levados em consideração entre outros.

Passada a análise dos projetos, chegou-se à execução da obra onde seria preenchido o formulário de investigação além de se ter feito contatos de modo informal 
com os funcionários da obra para sentir as reais condições da mão-de-obra sob o aspecto profissional e social.

Este formulário foi elaborado conforme a Tabela 15:

Obra:

Construtora:

Data:

TABELA 15 - Formulário de investigação "in loco".

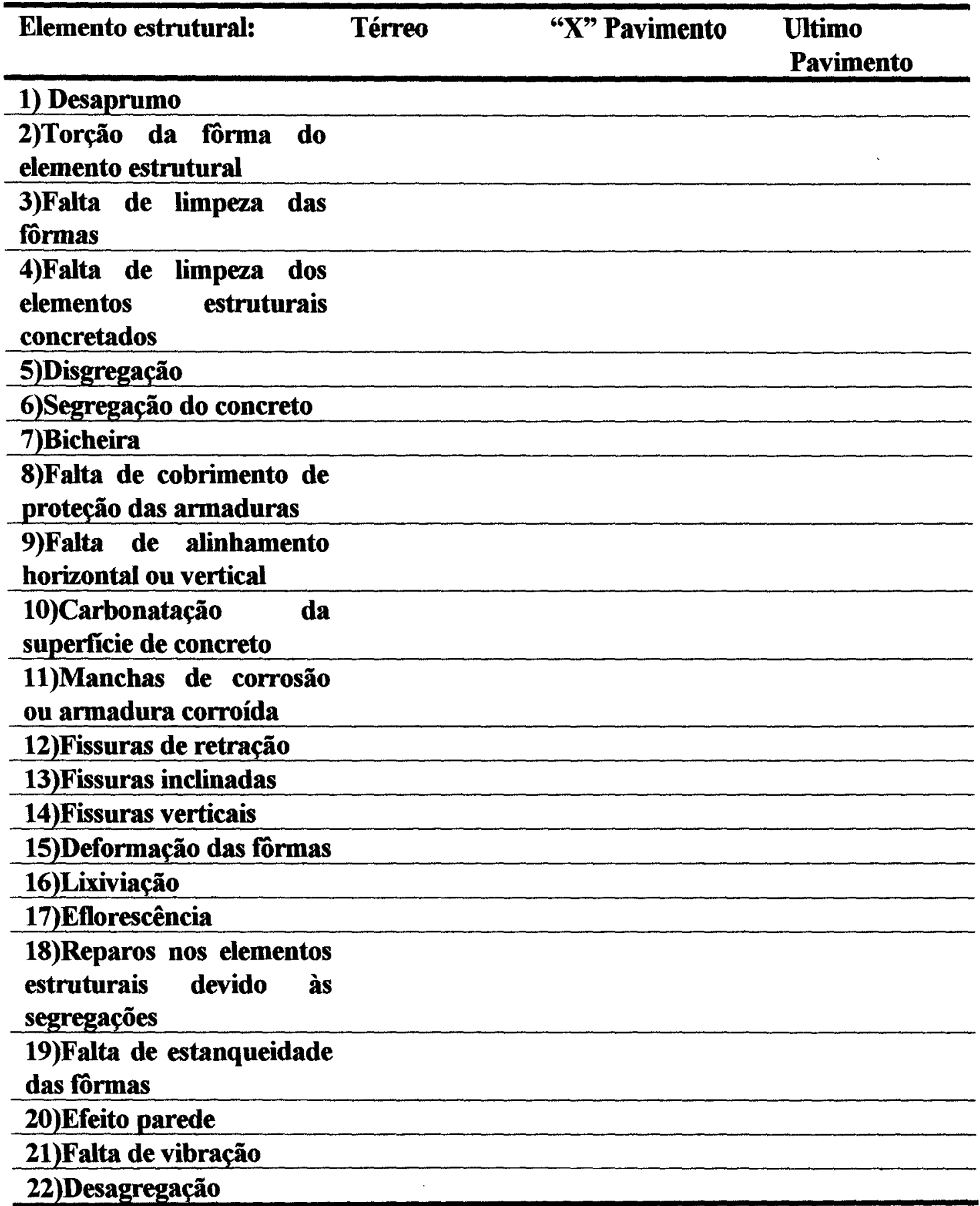


Esse formulário foi dividido por elemento estrutural existente na construção sendo que a cada formulário totalmente preenchido, teve-se a real situação patológica de cada um, a cada pavimento, do térreo ou subsolo até o último pavimento do edificio.

A forma de preenchimento deu-se por ocorrências, considerando cada manifestação uma ocorrência.

Portanto, como exemplo, para uma viga no $4^{\circ}$ Pavimento, ao se observar uma fissura, duas segregações e falta de cobrimento, marcava-se quatro ocorrências, cada qual no seu item correspondente.

No caso de se observarem manifestações como fissuras e carbonatação realizaramse ensaios "in loco" para avaliar a importância da manifestação e posteriormente constar no formulário.

Para as fissuras indicava-se cada uma, reproduzindo-as exatamente ao seu lado imitando sua disposição, além de posicioná-la no elemento estrutural. A seguir, com o auxílio de um fissurômetro, avaliava-se sua abertura para posteriormente serem fotografadas.

Para avaliar a profundidade de carbonatação dos elementos estruturais empregouse um indicador ácido-base de fenolftaleína. A escolha desse indicador deu-se pelo intervalo de $\mathrm{pH}$ que envolve a faixa que já acusa a perda de alcalinidade e permite uma avaliação quanto a carbonatação do concreto.

Para o caso do indicador de fenolftaleina, o indicador reage para $\mathrm{pH}$ compreendido entre 8,3 e 10 (FONTE; VOGEL, tab. 1.10 - Mudanças na cor e faixa de $\mathrm{pH}$ de alguns indicadores, p.66).

Para adotar as proporções desses indicadores utilizou-se o Método da Rilem (CPC-18) que recomenda uma solução com $1 \%$ de fenolftaleína em $70 \%$ de álcool etílico e $29 \%$ de água (em massa).

O procedimento utilizado para realizar o ensaio dá-se com o uso de um martelo para desagregar uma pequena parte da peça de concreto.

Em seguida, aplica-se através de spray a solução de fenolftaleína nas partes quebradas da peça em questão. 
Finalmente, verificava-se a mudança de cor da referida peça. Se aquela região permanece incolor significa que a mesma apresenta carbonatação $(\mathrm{pH}<8,3)$ e no caso do elemento estrutural permanecer magenta, ou seja, permanecer com a cor do indicador, a peça está com baixa ou nenhuma carbonatação $(\mathrm{pH}>10)$.

Só então, depois de analisada a profundidade da carbonatação, preenchia-se este item no formulário.

Foram retiradas amostras de barras de aço que estavam dispostas com a função de arranque em alguns elementos estruturais em algumas obras.

Essas amostras foram retiradas aleatoriamente onde a variável que determinava sua extração era a idade da obra.

No caso de obras que tiveram uma duração de construção maior, deixando esses arranques expostos por mais tempo, retirou-se esses elementos para a avaliação da seção nominal da barra com o intuito de calcular possíveis reduções da seção da armadura.

Em alguns casos quando se fez necessário algum esclarecimento de dúvidas surgidas, foram revistos os diários de obra para se verificar datas de concretagens antigas já esquecidas.

Nessas visitas às obras, outro ponto importante era se observar também se a edificação estava atendendo às exigências de projeto, ou seja, se as cargas de projeto estavam de acordo com os cálculos e se as resistências estavam compatíveis com as especificadas.

Algumas obras visitadas continham reparos estruturais em algumas de suas peças. Com o intuito acima descrito se fez necessário realizar ensaios não destrutivos. $\mathrm{O}$ ensaio adotado foi o de esclerometria que se realizou-se segundo o prescrito na NBR-7584.

Depois de levantadas todas as anomalias que tenham sido observadas e juntamente com o embasamento teórico, permitiu-se então detectar a/as causas que ocasionaram o problema patológico.

Foram compiladas todas as informações e através dos recursos estatísticos elaborou-se, para cada caso, um mapa estatístico correlacionando o número de ocorrências patológicas observadas em função de cada elemento estrutural vistoriado.

Feito esse mapa para cada edificio visitado partiu-se então para a globalização dos dados. 
Sendo assim, pode-se avaliar quais são as manifestações mais freqüentes de se observar nas construções correntes além de avaliar qual é o elemento estrutural que quantitativamente apresenta o maior número de problemas.

Com isso, em casos futuros, o intuito dessa relação elemento estrutural/maior incidência observada é permitir uma analogia para a avaliação de edificios que venham a apresentar problemas do ponto de vista patológico, ou seja, no momento que algum elemento estrutural apresentar um problema patológico, pode-se associar de antemão qual a possível incidência que está ocorrendo sem prévia visita.

Além disso, independente do elemento estrutural estudado é fato relevante tomar o conhecimento de que tipo de ocorrência torna-se a mais possível de desencadear manifestações patológicas devido seu grau de repetição, sejam elas advindas do projeto ou da construção e com isso procurar resolvê-las. 


\section{RESULTADOS}

\section{1 - OBSERVAÇÕES EM CONSTRUÇõES DO SUBSISTEMA ESTRUTURA}

Foram realizadas observações basicamente em edificios residenciais, estando a maior parte deles em fase construtiva, sendo que alguns se encontravam com suas obras paralisadas já há algum tempo e sem previsão de retorno num total de 11 edificios e 454 habitações.

Por se tratar de um trabalho exclusivamente cientifico, a autora reservou-se o direito de não identificar os casos, tendo em vista ser desnecessária a consideração desse aspecto, pois nada acrescenta aos estudos realizados.

$\mathrm{Na}$ apresentação das tabelas foram indicadas algumas manifestações tipicamente conhecidas e algumas que foram convencionadas no ato das visitas, de modo a alcançar uma retratação plena da situação.

As manifestações de conhecimento comum como carbonatação, eflorescência, lixiviação, segregação, disgregação, desagregação, fissuras, entre outras, estão definidas no Capítulo 3 dessa dissertação. As demais consideradas pela autora são explicadas a seguir:

- deformação das fôrmas: perda de suas características geométricas iniciais devido ao grande reaproveitamento, por falta de fechamento e/ou contraventamento, por excesso de travamento das fồmas pelo aperto demasiado de tensores, por excesso de adensamento do concreto, entre outros fatores, elas se deformam no instante da concretagem devido à pressão do concreto aplicada nas suas superficies como observado na Figura 31. Isto faz com que os elementos percam suas formas originais; 


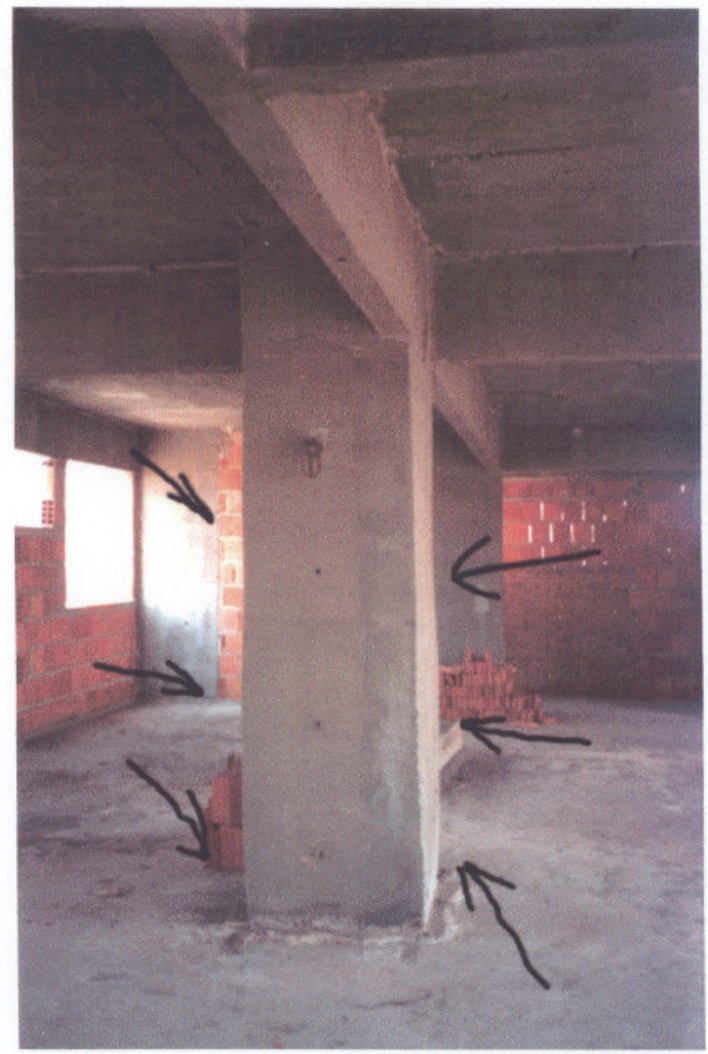

FIGURA 31 - Faces do pilar deformadas pela reutilização excessiva das fôrmas.

- desaprumo: falta de prumo do elemento estrutural em questão;

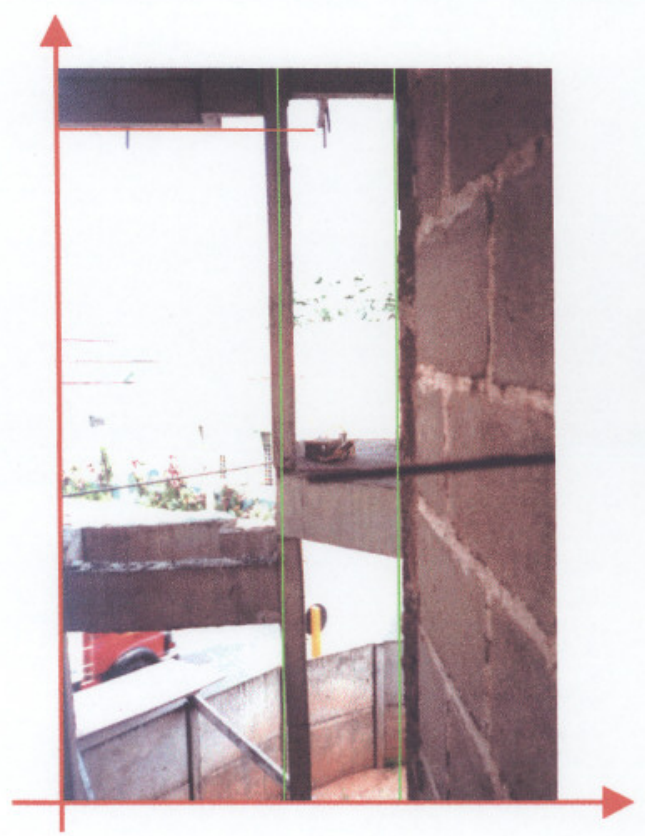

FIGURA 32 - Desaprumo das paredes estruturais ao longo dos pavimentos.

(observar linhas verdes ortogonais e paralelas às vermelhas indicando os eixos da foto)

- falta da camada de cobrimento de proteção das armaduras: espessura inferior à recomendada nas normas vigentes de estruturas de concreto entre a armadura e a superficie das fồrmas, permitindo, através do tempo e com ação de agentes nocivos, sua exposição superficial (Figura 33); 


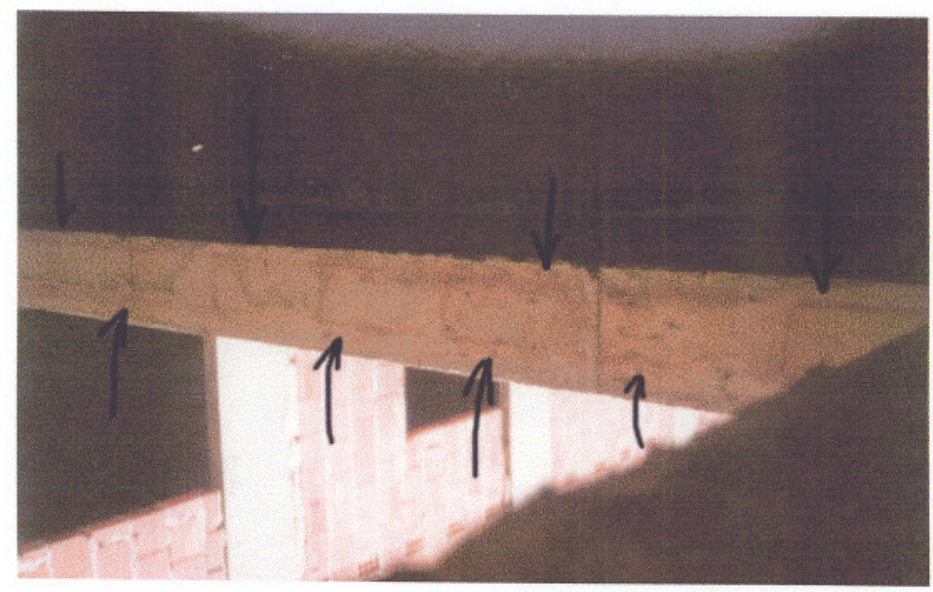

FIGURA 33 - Falta de cobrimento no fundo de viga.

- falta de alinhamento horizontal ou vertical: quando o elemento estrutural sai do seu plano horizontal ou vertical devido à falta de alinhamento das peças (Figura 34) no momento da montagem das fôrmas ou por falta de contraventamento destas que permite sua movimentação no momento da concretagem;

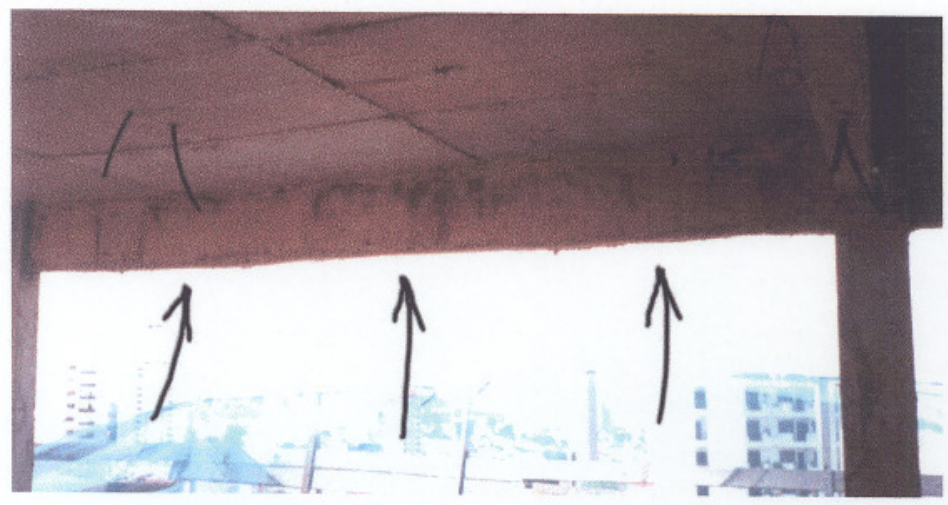

FIGURA 34 - Falta de alinhamento horizontal do fundo da viga.

- falta de estanqueidade: vedação, calafetação ineficiente das fồrmas, permitindo a fuga da pasta de cimento do concreto;

- falta de limpeza das fồmas: existência de detritos e sujeira proveniente de sobras de arame de amarração de ferragens, entre outras, fazendo com que toda a sujeira se incorpore no concreto e fique incrustada na peça depois de endurecida;

- falta de limpeza dos elementos estruturais: permanência de restos de compensado das fôrmas, pregos, etc., nas superficies dos elementos estruturais depois de concretados e desformados;

- falta de vibração: devido à interferência de outros subsistemas (Figura 35), o concreto não chega a ser adensado nesses pontos a fim de evitar que os eletrodutos se movimentem e saiam do lugar. Isso resulta na aparição de bicheiras nessas regiões; 


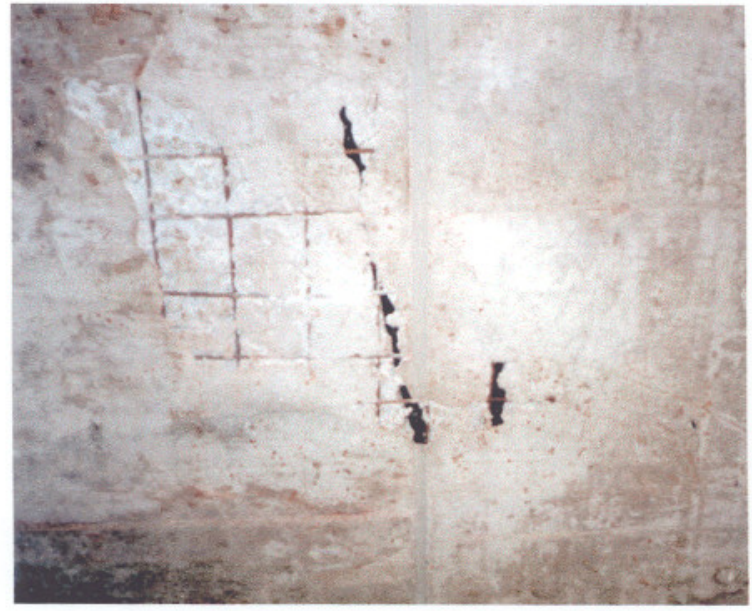

FIGURA 35 - Falta de vibração

devido à interferência do

subsistema de instalações elétricas

- junta de concretagem: após a interrupção de uma concretagem sem que a peça tenha sido completamente cheia, forma-se uma junta entre esse concreto já endurecido e o concreto novo que servirá para acabar a concretagem;

- reparo nos elementos estruturais devido a segregações: algumas peças, depois de concretadas apresentam segregações, formando bicheiras. Para ocultar esse defeito, é comum encontrar essas peças reparadas com argamassa (Figura 36).

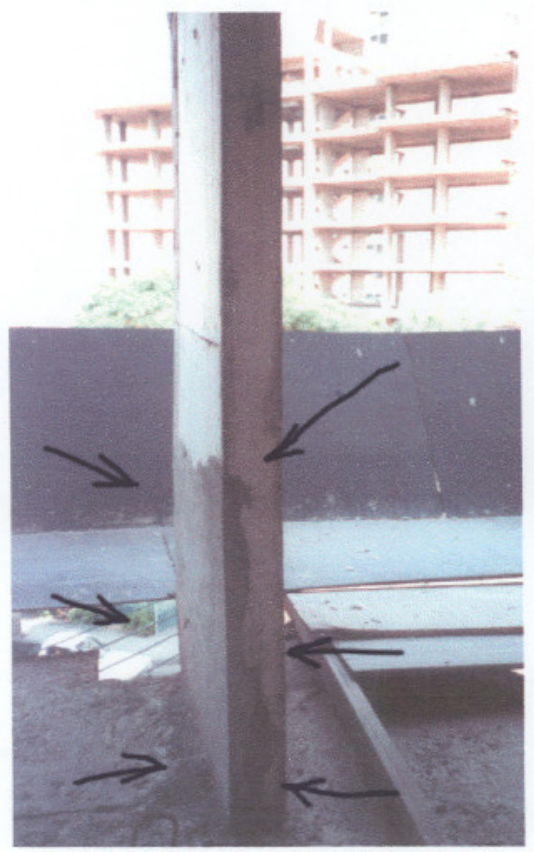

FIGURA 36 - Reparo com argamassa de cimento e areia no pé de pilar devido o excesso de segregações após à concretagem.

Devido ao grande número de tabelas elaboradas para a apresentação dos resultados, integraram neste capítulo as tabelas conclusivas de cada edificio.

As tabelas que apresentam as observações realizadas para cada elemento estrutural, a cada pavimento do edificio, são apresentadas sob a forma de anexo. 


\section{2 - EDIFÍCIO RESIDENCIAL "A"}

A inspeção do presente edificio foi realizada em meados de maio/98.

Nesse instante constatou-se que a obra iniciada em janeiro de 1997 encontrava-se com o subsistema estrutura e subsistema alvenaria em andamento, no sexto pavimento e no terceiro respectivamente.

O edificio residencial está inserido em ambiente urbano e constitui-se de doze pavimentos e uma cobertura, sendo que cada pavimento-tipo corresponde a quatro apartamentos, totalizando quarenta e nove habitações.

A infra-estrutura da edificação compõe-se dos seguintes elementos estruturais: tubulões, blocos e vigas baldrames.

A superestrutura é constituída por: pilares, paredes, vigas, lajes maciças, lajes nervuradas etc.

A armadura de todos os elementos estruturais compõe-se de barras e fios de aço CA-50 e CA-60 com emendas por traspasses quando necessárias. As barras foram todas armazenadas em canteiro, em local aberto, e não permaneciam por muito tempo na obra, pois eram compradas conforme a necessidade de empregá-las.

Quanto ao item projeto pode-se verificar a existência dos seguintes elementos: arquitetônico e estrutural, sistema hidráulico (água fria, quente, esgoto, incêndio), sistema elétrico e alvenaria. Não foram apresentados durante a inspeção o Memorial Descritivo, os sistemas de gás, telefonia, revestimentos, vedações, ar condicionado, etc., tal que permitissem verificar a interferência de todas as partes na edificação.

Quanto à postura tomada em canteiro com relação à qualidade, pode-se constatar que havia controle tecnológico do concreto. Porém, não era prática comum a anotação dos relatos ocorridos em obra, tampouco o controle dos outros materiais dos outros subsistemas.

Em relação ao aço, eram realizados ensaios em laboratório para a verificação de sua qualidade. Porém inexistiram controle das barras em campo no ato de sua utilização como amostragem por lotes. Já quanto à verificação de bitola, segundo relatos do mestre, contou-se com o critério da "prática" quando se empregaram as barras, ou seja, inexistiu controles.

Durante a execução não houve rotatividade de mão-de-obra na fase de infra e superestruturas. Porém houve mudança de engenheiro e mestre de obras no início da fase 
da superestrutura. Quanto aos serviços de alvenaria houve também rotatividade, pois esse serviço sempre foi subempreitado pela construtora.

As fôrmas foram compostas por material compensado resinado e plastificado, produzidas no próprio canteiro de obras. Havia apenas um jogo de fồrmas de modo que montava-se um pavimento, concretava-se e, verificada a resistência do concreto, compatível com a solicitação, procedia-se a desmoldagem dos elementos estruturais para aplicação no próximo pavimento. Assim era, sucessivamente, para as vigas e finalmente para as lajes. Até o momento da visita à obra, as fôrmas eram as mesmas que iniciaram a estrutura

$\mathrm{Na}$ obra em questão, a construtora empregava pela primeira vez escoramento metálico para os elementos estruturais e, como nova postura, seria adotado esse tipo de escoramento para todas as futuras obras por ter-se percebido grandes vantagens quanto ao tempo e principalmente no resultado final obtido.

Após cada desforma, limpavam-se as fôrmas e aplicava-se desmoldante para se garantir acabamento nos elementos estruturais, além de preservá-las para serem montadas novamente no próximo pavimento.

Através de informações obtidas do mestre de obras e posteriormente na inspeção "in loco", verificou-se que foram empregados elementos espaçadores do tipo pastilhas e caranguejos nas lajes, e pastilhas e galgas nos pilares. Para as vigas não foi empregado nenhum elemento espaçador.

O concreto utilizado nos elementos estruturais foi todo fornecido por concreteira. Houve distinção do $f_{c k}$ para os diferentes elementos estruturais. Para as vigas e lajes foi empregado $f_{c k}$ de $20 \mathrm{MPa}$; para os pilares, paredes e blocos, o $f_{c k}$ empregado foi de $25 \mathrm{MPa}$; finalmente para os tubulões empregou-se $\mathrm{f}_{\mathrm{ck}}$ de $15 \mathrm{MPa}$.

Antes do início de cada concretagem, as fồmas recebiam limpeza final e a operação somente era liberada após a vistoria do engenheiro e do mestre, para então serem molhadas e permitirem o início dos trabalhos

Para realização do adensamento do concreto, foram utilizados vibradores com agulhas de $37 \mathrm{~mm}$ e $45 \mathrm{~mm}$ de diâmetro, variando-se as características da agulha conforme a peça a ser concretada. Para as nervuras das lajes empregava-se agulha de $37 \mathrm{~mm}$ bem como para as vigas estreitas. Para os outros elementos estruturais utilizava-se agulhas de $45 \mathrm{~mm}$. 
Quanto ao início dos trabalhos de concretagem, mantinha-se pré-estabelecido o horário (manhã) para dar tempo suficiente de se concretar um pavimento no mesmo dia.

Após o início de pega do concreto, começava o processo de cura. As lajes começavam a ser molhadas desde o instante em que o concreto apresentasse um início de endurecimento, e o processo continuava pelos três primeiros dias de idade entre oito e dez vezes ao dia. Após o terceiro dia a rega se dava de três a quatro vezes ao dia por um período de sete a dez dias.

As vigas seguiam o mesmo critério das lajes.

Os pilares eram concretados em duas fases. Concretava-se a primeira fase que chegava até a altura do fundo das vigas. Após a segunda fase, assim que o concreto iniciava seu processo de endurecimento, umedecia-se as fồmas desses elementos de forma abundante e deixava-se uma lâmina de água de aproximadamente $4 \mathrm{~mm}$ na cabeça do pilar. Esse procedimento ocorria de duas a três vezes ao dia por um período de sete dias.

Caso os dias seguintes à concretagem dos elementos fossem muito quentes, a rega se dava durante todo dia em todas as peças concretadas para formar uma lâmina de água sobre as superficies. Isso ocorria pelo menos nos três primeiros dias de idade.

No item descimbramento e reescoramento, retiravam-se as fôrmas primeiro dos pilares e depois de vigas e lajes. Dos pilares retiravam-se as fồrmas dez dias após a concretagem. De vigas e lajes retiravam-se as escoras e fazia-se o reescoramento entre dez e quinze dias após a retirada das fôrmas dos pilares.

Nas lajes, a retirada das fôrmas começava de um extremo para outro, e a cada painel da fôrma que era retirado colocavam-se duas escoras. Nas vigas mantinha-se o critério de começar o reescoramento do meio do vão para suas extremidades. A cada escora retirada do meio do vão colocava-se outras duas, uma de cada lado da posição da escora inicial retirada e assim sucessivamente até chegar nas laterais.

Segundo o engenheiro responsável, quanto às possíveis anormalidades durante a obra, como problemas estruturais, grandes mudanças de projeto em obra, etc., cita-se a substituição de armadura. Em um instante da obra estava sobrando muito aço com bitola de $10,00 \mathrm{~m}$. Substituiu-se então todas as barras de um pavimento de $8,00 \mathrm{~mm}$ para $10,00 \mathrm{~mm}$. Consequentemente, aumentou-se o espaçamento entre barras de $10,00 \mathrm{~cm}$ para $12,50 \mathrm{~cm}$. 
São apresentadas a seguir as principais patologias observadas na obra (Tabela 16).

Vale mencionar alguns critérios adotados que valem para todos os casos apresentados.

Nas tabelas que seguem os dados são apresentados sob a forma de número de incidências observadas por elemento estrutural por pavimento. Porém algumas porcentagens extrapolam os cem por cento. Isso se deve ao fato de que apesar de existir um certo número de elementos estruturais por pavimento era comum observar mais de um tipo de patologia num mesmo elemento.

Como se convencionou que cada observação contaria uma anotação, no final das estatísticas é comum os números superarem os $100 \%$.

Outra conduta que deve ser esclarecida é de como se fizeram essas anotações das observações.

Se em uma peça fossem detectados três tipos de manifestações haveria três anotações. $O$ mesmo ocorreu para o caso das manifestações serem todas do mesmo tipo, porém em pontos diferentes do elemento estrutural.

Por exemplo, se em um pilar eram observadas segregações no pé e na sua altura média, falta de cobrimento e corrosão de armadura no pé do elemento, foram feitas quatro anotações.

Em alguns casos, dependendo do estágio em que se encontrava a obra, algumas vezes não era possível, por exemplo, observar todas as faces de uma viga ou qualquer outro elemento estrutural. Nesses casos, as tabelas correspondentes contêm notas sobre esse aspecto. Caso não haja citações sobre isso nas tabelas, ocorre que a vistoria pôde ser feita sem nenhum impedimento. 
TABELA 16 - Número de observações e porcentagens de incidências patológicas parciais para cada elemento estrutural e integral do edificio " $A$ ".

\begin{tabular}{|c|c|c|c|c|c|c|c|c|c|c|}
\hline \multirow{2}{*}{$\begin{array}{l}\text { Eemento Estrutural } \\
\text { Tipo de manifestaça patologica observada }\end{array}$} & \multicolumn{2}{|c|}{ Laje } & \multicolumn{2}{|c|}{ Viga } & \multicolumn{2}{|c|}{ Pilar } & \multicolumn{2}{|c|}{ Parede } & \multicolumn{2}{|c|}{ Total } \\
\hline & $\$$ & $\%$ & $\$$ & $\%$ & $\$$ & $\%$ & $\$$ & $\%$ & \# & $\% *$ \\
\hline desaprumo & 0 & - & 0 & - & 0 & - & 0 & - & 0 & - \\
\hline torctao da forma & 0 & - & 1 & 0,34 & 0 & - & 0 & $\therefore$ & 1 & 0,16 \\
\hline junta de concretagem & 0 & - & 4 & 1,36 & 0 & - & 0 & - & 4 & 0,65 \\
\hline falla de linpeza das formas & 34 & 37,78 & 60 & 20,41 & 0 & - & 0 & - & 94 & 15,21 \\
\hline falla de estanqueidade das formas & 16 & 17,78 & 88 & 29,93 & 0 & - & 0 & - & 104 & 16,83 \\
\hline talla de limpeza nos elementos estruturais & 0 & - & 0 & - & 0 & - & 0 & - & 0 & $=$ \\
\hline disgregacto & 0 & - & 4 & 1,36 & 0 & - & 0 & - & 4 & 0,65 \\
\hline bichelras & 16 & 17,78 & 2 & 0,68 & 12 & 5,41 & 3 & 25,00 & 33 & 5,34 \\
\hline segregacto do concreto & 9 & 10,00 & 166 & 56,46 & 176 & 79,28 & 10 & 83,33 & 361 & 58,41 \\
\hline falla de cobrinento de protecáo das armaduras & 21 & 23,33 & 204 & 69,39 & 2 & 0,90 & 2 & 16,67 & 229 & 37,06 \\
\hline efeilo parede & 21 & 23,33 & 0 & - & 2 & 0,90 & 0 & - & 23 & 3,72 \\
\hline falta de allnhamento horizontal ou vertical & 1 & 1,11 & 16 & 5,44 & 0 & - & 3 & 25,00 & 20 & 3,24 \\
\hline carbonatacao na camada de cobrimento & 1 & 1,11 & 0 & - & 0 & - & 0 & - & 1 & 0,16 \\
\hline manchas de corros ao ou armadura corroida & 7 & 7,78 & 55 & 18,71 & 1 & 0,45 & 0 & - & 63 & 10,19 \\
\hline fissuras de retraço & 0 & - & 18 & 6,12 & 1 & 0,45 & 0 & - & 19 & 3,07 \\
\hline fissuras helinadas & 2 & 2,22 & 0 & - & 0 & - & 0 & - & 2 & 0,32 \\
\hline fissuras em tubulacto & 0 & - & 20 & 6,80 & 0 & - & 0 & - & 20 & 3,24 \\
\hline fissuras verticais & 0 & - & 19 & 6,46 & 0 & - & 0 & - & 19 & 3,07 \\
\hline deformacto das formas & 4 & 4,44 & 12 & 4,08 & 2 & 0,90 & 1 & 8,33 & 19 & 3,07 \\
\hline reparos nos e.e devido segregagdes & 0 & - & 0 & - & 0 & $=$ & 0 & - & 0 & - \\
\hline Exiviagáo & 2 & 2,22 & 1 & 0,34 & 0 & - & 0 & - & 3 & 0,49 \\
\hline efiorescenclas & 2 & 2,22 & 0 & - & 0 & - & 0 & - & 2 & 0,32 \\
\hline falta de voracao & 0 & - & 0 & - & 0 & - & 0 & - & 0 & - \\
\hline desagregactäo do concreto & 0 & - & 0 & - & 0 & - & 0 & - & 0 & - \\
\hline
\end{tabular}

\section{3 - EDIFÍCIO RESIDENCIAL "B"}

A inspeção do presente edifício foi realizada em meados de setembro/97.

A obra começou no final de 1993 e, no momento da visita, observou-se que o subsistema estrutura ainda não havia sido concluído, faltando três pavimentos-tipo e cobertura a serem feitos. O subsistema alvenaria já havia sido iniciado chegando ao oitavo pavimento.

O edificio está inserido em ambiente urbano, e constitui-se por sobreloja, quatorze pavimentos-tipo contendo dois apartamentos e uma cobertura. Total de vinte e nove habitações.

A infra-estrutura da edificação compõe-se dos seguintes elementos estruturais: tubulões, blocos, vigas baldrames, vigas alavancas.

A superestrutura é constituída por: pilares, paredes, vigas, lajes maciças, etc. Não existem elementos de contraventamento da estrutura.

A armadura de todos os elementos estruturais compõe-se de barras e fios de aço CA-50 com emendas por traspasses quando necessárias. As barras foram todas 
armazenadas em canteiro, no subsolo, em local coberto e não permaneciam por muito tempo na obra, pois eram compradas conforme a necessidade de empregá-las.

Quanto ao item projeto pode-se verificar a existência dos seguintes elementos: arquitetônico e estrutural. Não foram apresentados durante a inspeção o Memorial Descritivo, o sistema hidráulico (água fria, quente, esgoto, incêndio), bem como os demais sistemas descritos para o edificio " $\mathrm{A}$ ", tal que permitissem verificar a interferência de todas as partes na edificação.

Quanto à postura tomada em canteiro com relação à qualidade, pode-se constatar que havia controle tecnológico do concreto. Porém, não era prática comum a anotação dos relatos ocorridos em obra, tampouco o controle dos outros materiais dos outros subsistemas.

Em relação ao aço, foram realizados alguns ensaios em laboratório para se comprovar sua qualidade. $O$ controle das barras em campo no ato de sua utilização se deu por verificação de bitolas.

Durante a execução não houve rotatividade de mão-de-obra, permanecendo praticamente os mesmos funcionários da construtora. Houve variação de carpinteiros e ferreiros, pois foram serviços subempreitados pela construtora.

As fôrmas foram compostas por material compensado resinado (madeirite), produzidas no próprio canteiro de obras. Havia apenas um jogo de fôrmas, de modo que montava-se um pavimento, concretava-se e, verificada a resistência do concreto, compatível com a solicitação, procedia-se à desmoldagem dos elementos estruturais para aplicação no próximo pavimento. Assim era, sucessivamente, para as vigas e finalmente para as lajes. O reaproveitamento foi de fator 15 (conforme relatos), ou seja, o mesmo jogo de fôrmas foi utilizado em todos os pavimentos sendo substituídas apenas partes dos moldes que já não apresentavam condições de uso.

Após cada desforma, limpavam-se as fôrmas e aplicava-se desmoldante para se garantir acabamento nos elementos estruturais, além de preservá-las para serem montadas novamente no próximo pavimento.

Através de informações obtidas do mestre de obras e posteriormente verificadas na inspeção "in loco", não foram empregados elementos espaçadores, quer sejam pastilhas, "caranguejos" ou qualquer outro tipo de elemento auxiliar no posicionamento da armadura. 
O concreto utilizado nos elementos estruturais foi todo fornecido por concreteira local. $O \mathrm{f}_{\mathrm{ck}}$ especificado foi de $18 \mathrm{MPa}$, com brita 1 para as lajes e, com brita 1 e 2 para as vigas, paredes e pilares. Para os tubulões especificou-se $\mathrm{f}_{\mathrm{ck}}$ de $15 \mathrm{MPa}$.

Antes do início de cada concretagem, as fồmas recebiam limpeza final e a operação somente era liberada após a vistoria do engenheiro e do mestre, para então serem molhadas e permitirem o início dos trabalhos.

Para realização do adensamento do concreto, foram utilizados vibradores com agulhas de $45 \mathrm{~mm}$ de diâmetro.

$\mathrm{O}$ início das concretagens sempre se dava no começo do dia. Era comum não haver tempo suficiente para se concluir uma concretagem num mesmo dia devido ao grande volume de concreto $\left(\cong 56 \mathrm{~m}^{3}\right)$, sendo que no seguinte retomava-se a concretagem pelo trecho interrompido no dia anterior, estabelecendo-se então uma junta de concretagem.

O processo de cura começava aproximadamente três horas depois do início da concretagem, molhando o concreto três vezes ao dia. $\mathrm{O}$ procedimento adotado, segundo depoimentos do mestre, era de continuar a molhagem de lajes e vigas por mais dois dias depois da concretagem. Os pilares não faziam parte desse procedimento pois não eram molhados.

A fase de desforma não cumpriu nenhum planejamento, sendo que a retirada das escoras das vigas e das lajes estava acordo apenas com as instruções do mestre. Quanto à desforma dos elementos estruturais, retiravam-se as fồmas de pilares e vigas sete a oito dias após a concretagem. Para as lajes se aguardava um pouco mais, sendo retiradas as fôrmas entre dez e doze dias depois da concretagem.

No caso de um pavimento ser concretado num período menor que um mês relativamente ao pavimento inferior, fazia-se reescoramento das vigas e lajes desse pavimento inferior. Caso o intervalo de tempo entre concretagem fosse maior que um mês não se realizava o reescoramento.

Segundo o engenheiro responsável, não ocorreu nenhuma anormalidade durante a execução, como problemas estruturais, grandes mudanças de projeto em obra ou substituições de bitolas de aço.

São apresentadas a seguir as principais patologias observadas em obra através da Tabela 17. 
TABELA 17 - Número de observações e porcentagens de incidências patológicas parciais para cada elemento estrutural e integral do edificio " $B$ ".

\begin{tabular}{|c|c|c|c|c|c|c|c|c|c|c|}
\hline \multirow{2}{*}{$\begin{array}{l}\text { Eemento Estrutural } \\
\text { Tipo de manifestaçao patolbgica observada }\end{array}$} & \multicolumn{2}{|c|}{ Laje } & \multicolumn{2}{|c|}{ Viga } & \multicolumn{2}{|c|}{ Pilar } & \multicolumn{2}{|c|}{ Parede } & \multicolumn{2}{|c|}{ Total } \\
\hline & $\$$ & $\%$ & $\$$ & $\%$ & $\$$ & $\%$ & $\$$ & $\%$ & $\#$ & $\% *$ \\
\hline desaprumo & 0 & - & 0 & - & 27 & 9,64 & 4 & 1,79 & 31 & 2,88 \\
\hline torctao da forma & 0 & - & 14 & 3,33 & 8 & 2,86 & 5 & 2,23 & 27 & 2,50 \\
\hline Junta de concretagem & 2 & 1,30 & 13 & 3,10 & 1 & 0,36 & 8 & 3,57 & 24 & 2,23 \\
\hline falta de limpeza das formas & 51 & 33,12 & 9 & 2,14 & 4 & 1,43 & 2 & 0,89 & 66 & 6,12 \\
\hline falta de estanqueidade das formas & 64 & 41,56 & 34 & 8,10 & 11 & 3,93 & 17 & 7,59 & 126 & 11,69 \\
\hline falta de limpeza elementos estruturais & 18 & 11,69 & 15 & 3,57 & 5 & 1,79 & 8 & 3,57 & 46 & 4,27 \\
\hline dlsgregacăo & 0 & - & 1 & 0,24 & 2 & 0,71 & 2 & 0,89 & 5 & 0,46 \\
\hline bicheiras & 1 & 0,65 & 20 & 4,76 & 12 & 4,29 & 8 & 3,57 & 41 & 3,80 \\
\hline segregasao do concreto & 8 & 5,19 & 136 & 32,38 & 111 & 39,64 & 81 & 36,16 & 336 & 31,17 \\
\hline falta de cobrimento de proteça das armaduras & 12 & 7,79 & 64 & 15,24 & 15 & 5,36 & 15 & 6,70 & 106 & 9,83 \\
\hline efeito parede & 81 & 52,60 & 0 & - & 0 & - & 0 & - & 81 & 7,51 \\
\hline falta de alinhamento horizontal ou vertical & 29 & 18,83 & 50 & 11,90 & 9 & 3,21 & 19 & 8,48 & 107 & 9,93 \\
\hline carbonataça na superficie de concreto & 0 & - & 0 & - & 0 & - & 0 & - & 0 & - \\
\hline manchas de corrosäo ou armadura corrolda & 6 & 3,90 & 21 & 5,00 & 9 & 3,21 & 16 & 7,14 & 52 & 4,82 \\
\hline fissuras de retragao & 0 & - & 2 & 0,48 & 0 & - & 0 & - & 2 & 0,19 \\
\hline ftssuras inc Enadas & 29 & 18,83 & 0 & - & 0 & - & 0 & - & 29 & 2,69 \\
\hline fissuras em tubulacaso & 0 & - & 25 & 5,95 & 0 & - & 0 & - & 25 & 2,32 \\
\hline fissuras verticais & 0 & - & 24 & 5,71 & 0 & - & 0 & - & 24 & 2,23 \\
\hline deformaça das formas & 5 & 3,25 & 37 & 8,81 & 59 & 21,07 & 27 & 12,05 & 128 & 11,87 \\
\hline reparos nos el estrut. devido segregagoes & 0 & - & 20 & 4,76 & 22 & 7,86 & 41 & 18,30 & 83 & 7,70 \\
\hline Ixiviagáo & 29 & 18,83 & 3 & 0,71 & 0 & - & 0 & - & 32 & 2,97 \\
\hline eflorescencias & 29 & 18,83 & 3 & 0,71 & 0 & - & 0 & - & 32 & 2,97 \\
\hline falta de vibraçăo & 7 & 4,55 & 0 & - & 0 & - & 0 & - & 7 & 0,65 \\
\hline desagregaçao do concreto & 0 & - & 0 & - & 0 & - & 0 & - & 0 & - \\
\hline
\end{tabular}

\section{4 - EDIFÍCIO RESIDENCIAL "C"}

A inspeção do presente edificio foi realizada em meados de dezembro/97.

Nesse instante constatou-se que a obra iniciada em 1994 encontrava-se com o subsistema estrutura ainda em fase de construção estando concretado até o décimo-quinto pavimento. O subsistema alvenaria já havia sido iniciado, estando todas as paredes externas de todos os pavimentos já levantadas.

O edificio residencial está inserido em ambiente urbano e constitui-se por dezessete pavimentos-tipo, loja, sobreloja e dois subsolos, sendo que cada pavimento tipo corresponde a três apartamentos, totalizando cinqüenta e uma habitações.

A infra-estrutura da edificação compõe-se dos seguintes elementos estruturais: estacas, blocos, vigas baldrames, vigas alavancas.

A superestrutura é constituída por: pilares, paredes, mísulas, consoles, vigas, lajes maciças, etc.

A armadura de todos os elementos estruturais compõe-se de barras e fios de aço CA-50 e CA-60 com emendas por traspasses quando necessárias. As barras foram todas 
armazenadas em canteiro, em local coberto e não permaneciam por muito tempo na obra, pois eram compradas conforme a necessidade de empregá-las.

Quanto ao item projeto pode-se verificar a existência dos seguintes elementos: arquitetônico, fundações, estrutural, hidráulico e elétrico. Não foram apresentados durante a inspeção o Memorial Descritivo e os sistemas de gás, telefonia, alvenarias, revestimentos, vedações, ar condicionado, etc., tal que permitissem verificar a interferência de todas as partes da edificação.

Quanto à postura tomada em canteiro com relação à qualidade, pôde-se constatar que havia controle tecnológico do concreto. Porém, não era prática comum a anotação dos relatos ocorridos em obra, tampouco o controle dos outros materiais dos outros subsistemas.

Em relação ao aço, não foi efetuado nenhum tipo de ensaio em laboratório. Inexistiu controle das barras em campo no ato de sua utilização (amostragem por lotes, verificação de bitola, por exemplo) .

Durante a execução não houve rotatividade de mão-de-obra nem serviços subempreitados, pois todos os funcionários são contratados da construtora.

As fôrmas foram compostas por material compensado resinado plastificado, produzidas no próprio canteiro de obras. Havia apenas um jogo de fồrmas, de modo que montava-se um pavimento, concretava-se e verificada a resistência do concreto, compatível com a solicitação, procedia-se à desmoldagem dos elementos estruturais para aplicação no próximo pavimento. Assim era, sucessivamente, para as vigas e finalmente para as lajes. $\mathrm{O}$ mesmo jogo de fồrmas foi utilizado aproximadamente quinze vezes. $\mathrm{A}$ partir do décimo-primeiro pavimento foi empregado novo jogo de fồrmas.

Após cada desforma, limpavam-se as fôrmas e aplicava-se desmoldante para se garantir acabamento nos elementos estruturais além de preservá-las para serem montadas novamente no próximo pavimento.

Através de informações obtidas do engenheiro da obra foram empregados elementos espaçadores para auxiliar no posicionamento da armadura.

O concreto utilizado nos elementos estruturais foi todo fornecido por concreteira local. O $\mathrm{f}_{\mathrm{ck}}$ empregado foi de $18 \mathrm{MPa}$ para todos os elementos estruturais, só havendo distinção para as estacas onde se empregou $\mathrm{f}_{\mathrm{c}}$ de $15 \mathrm{MPa}$. 
Antes do início de cada concretagem, as fôrmas recebiam limpeza final e a operação somente era liberada após a vistoria do engenheiro e do mestre, para então serem molhadas e permitirem o início dos trabalhos

Para realização do adensamento do concreto, foram utilizados vibradores com agulhas de $37 \mathrm{~mm}$ e $45 \mathrm{~mm}$ de diâmetro, variando-se as características da agulha conforme a peça a ser concretada.

O início de uma concretagem era realizado o mais cedo possível para se evitar ao máximo grandes interrupções. Porém, sempre que se fazia necessário parar uma concretagem, procurava-se interrompê-la em uma mesma região para todos os pavimentos, estabelecendo-se então uma junta de concretagem sempre no mesmo lugar.

Após o início de pega do concreto, começava o processo de cura. Molhava-se as lajes no instante em que o concreto apresentasse um princípio de endurecimento. $O$ processo se prolongava por um período de três dias. Todavia, a cura úmida só atingia as lajes, pois os pilares não eram molhados e as vigas recebiam um quinhão de molhagem proveniente apenas da rega das lajes.

A fase de desforma das lajes e vigas cumpria o planejamento, com retirada das escoras das vigas e das lajes de acordo com as ordens do profissional responsável.

Segundo o engenheiro responsável, não ocorreu nenhuma anormalidade durante a execução, como problemas estruturais, grandes mudanças de projeto ou substituições de bitolas de aço.

Os resultados seguem através da Tabela 18 . 
TABELA 18 - Número de observações e porcentagens de incidências patológicas parciais para cada elemento estrutural e integral do edifício "C".

\begin{tabular}{|c|c|c|c|c|c|c|c|c|c|c|}
\hline \multirow{2}{*}{$\begin{array}{l}\text { Eemento Estrutural } \\
\text { Tipo de manifestação patologica observada }\end{array}$} & \multicolumn{2}{|c|}{ Laje } & \multicolumn{2}{|c|}{ Viga } & \multicolumn{2}{|c|}{ Pilar } & \multicolumn{2}{|c|}{ Parede } & \multicolumn{2}{|c|}{ Total } \\
\hline & $\$$ & $\%$ & $\$$ & $\%$ & $\$$ & $\%$ & $\$$ & $\%$ & $\#$ & $\% *$ \\
\hline de saprumo & 0 & - & 0 & - & 2 & 1.33 & 1 & 0,67 & 3 & 0.21 \\
\hline torção da forma & 0 & - & 22 & 2,88 & 5 & 3,33 & 6 & 4,00 & 33 & 2,32 \\
\hline junta de concretagem & 0 & - & 14 & 1,83 & 0 & - & 1 & 0,67 & 15 & 1,05 \\
\hline falta de limpeza das formas & 23 & 6,39 & 27 & 3,53 & 2 & 1,33 & 1 & 0,67 & 53 & 3,72 \\
\hline falta de estanqueidade das formas & 79 & 21,94 & 59 & 7,71 & 0 & - & 10 & 6,67 & 148 & 10,39 \\
\hline falla de limpeza elementos estruturals & 0 & - & 0 & - & 0 & - & 0 & - & 0 & - \\
\hline disgregacáo & 2 & 0,56 & 0 & - & 1 & 0,67 & 0 & - & 3 & 0,21 \\
\hline bicheiras & 1 & 0,28 & 30 & 3,92 & 11 & 7,33 & 21 & 14,00 & 63 & 4,42 \\
\hline segregacto do concreto & 0 & - & 131 & 17,12 & 120 & 80,00 & 108 & 72,00 & 359 & 25,19 \\
\hline falta de cobrimento de proteçăo das armaduras & 75 & 20,83 & 209 & 27,32 & 9 & 6,00 & 3 & 2,00 & 296 & 20,77 \\
\hline efelto parede & 89 & 24,72 & 0 & - & 0 & - & 0 & - & 89 & 6,25 \\
\hline falta de alinhamento horizontal ou vertical & 6 & 1,67 & 42 & 5,49 & 20 & 13,33 & 8 & 5,33 & 76 & 5,33 \\
\hline carbonataça na superficie de concreto & 0 & - & 0 & - & 0 & - & 0 & - & 0 & - \\
\hline manchas de corrosto ou armadura corrofida & 7 & 1,94 & 2 & 0,26 & 0 & - & 1 & 0,67 & 10 & 0,70 \\
\hline fissuras de retragáo & 0 & - & 8 & 1,05 & 0 & - & 0 & - & 8 & 0,56 \\
\hline fissuras inclinadas & 53 & 14,72 & 0 & - & 0 & - & 0 & - & 53 & 3,72 \\
\hline fissuras em tubulaçáo & 0 & - & 6 & 0,78 & 0 & - & 0 & - & 6 & 0,42 \\
\hline fis suras verticals & 0 & - & 13 & 1,70 & 0 & - & 0 & - & 13 & 0,91 \\
\hline deformacăo das formas & 0 & - & 38 & 4,97 & 56 & 37,33 & 18 & 12,00 & 112 & 7,86 \\
\hline reparos nos el. estrut de vido segregacóes & 0 & - & 11 & 1,44 & 5 & 3,33 & 5 & $3, \overline{33}$ & 21 & 1,47 \\
\hline fxiviaçăo & 62 & 17,22 & 1 & 0,13 & 0 & - & 0 & - & 63 & 4,42 \\
\hline efiorescenclas & 58 & 16,11 & 1 & 0,13 & 0 & - & 0 & - & 59 & 4,14 \\
\hline falta de vibraçao & 12 & 3,33 & 0 & - & 0 & - & 0 & - & 12 & 0,84 \\
\hline desagregaça do concre to & 0 & $\because$ & 1 & 0,13 & 0 & - & 0 & - & 1 & 0,07 \\
\hline
\end{tabular}

\section{5 - EDIFÍCIO RESIDENCIAL "D"}

A inspeção do presente edificio foi realizada em meados de agosto/97.

Nesse instante constatou-se que a obra iniciada em 1996 encontrava-se com o subsistema estrutura ainda em fase de construção estando concretado até o quarto pavimento. O subsistema alvenaria havia chegado até o segundo pavimento.

O edifício residencial está inserido em ambiente urbano e constitui-se por doze pavimentos-tipo, loja e subsolo, sendo que cada pavimento-tipo corresponde a cinco apartamentos e um duplex, totalizando sessenta e seis habitações.

A infra-estrutura da edificação compõe-se dos seguintes elementos estruturais: tubulões, blocos, vigas baldrames, vigas alavancas.

A superestrutura é constituída por: pilares, paredes, vigas, lajes maciças, etc.

A armadura de todos os elementos estruturais compõe-se de barras e fios de aço CA-50 e CA-60 com emendas por traspasses quando necessárias. As barras foram todas armazenadas em canteiro, em local coberto, e não permaneciam por muito tempo na obra pois eram compradas conforme a necessidade de empregá-las.

Quanto ao item projeto pode-se verificar a existência dos seguintes elementos: arquitetônico, fundações, drenagem do subsolo, estrutural, hidráulico e elétrico. Não foram 
apresentados durante a inspeção o Memorial Descritivo e os sistemas de gás, telefonia, alvenarias, revestimentos, vedações, ar condicionado, etc., tal que permitisse verificar a interferência de todas as partes da edificação.

Quanto à postura tomada em canteiro em relação à qualidade, pôde-se constatar que havia controle tecnológico do concreto. Porém, não era prática comum a anotação dos relatos ocorridos em obra, tampouco o controle dos outros materiais dos outros subsistemas.

Em relação ao aço, não foi efetuado nenhum tipo de ensaio em laboratório. Quanto à postura em obra, houve controle das barras em campo no ato de sua utilização (amostragem por lotes, verificação de bitola, por exemplo).

Durante a execução não houve rotatividade de mão-de-obra nem serviços subempreitados, pois todos os funcionários da obra são contratados da construtora.

As fồmas foram compostas por material compensado resinado plastificado, produzidas no próprio canteiro de obras. Havia apenas um jogo de fôrmas, de modo que montava-se um pavimento, concretava-se e, verificada a resistência do concreto, compatível com a solicitação, procedia-se à desmoldagem dos elementos estruturais para aplicação no próximo pavimento. Assim era, sucessivamente, para os pilares, para as vigas e finalmente para as lajes. Até o momento da visita à obra o jogo de fôrmas empregado era o mesmo e a intenção era de utilizá-lo até o momento que elas ainda oferecessem condições de uso.

Após cada desforma, limpava-se as fôrmas e aplicava-se desmoldante para se garantir acabamento nos elementos estruturais além de preservá-las para serem montadas novamente no próximo pavimento.

Através de informações obtidas do engenheiro da obra foram empregados elementos espaçadores para auxiliar no posicionamento da armadura.

O concreto utilizado nos elementos estruturais foi todo fornecido por concreteira local. $\mathrm{O} \mathrm{f}_{\mathrm{ck}}$ empregado foi de $25 \mathrm{MPa}$ para todos os elementos estruturais, só havendo distinção para os tubulões, onde se empregou $f_{c k}$ de $15 \mathrm{MPa}$

Antes do início de cada concretagem, as fồmas recebiam limpeza final e a operação somente era liberada após a vistoria do engenheiro e do mestre, para então serem molhadas e permitirem o início dos trabalhos. 
Para realização do adensamento do concreto foram utilizados vibradores com agulhas de $45 \mathrm{~mm}$ de diâmetro.

As concretagens começavam o mais cedo possível para se evitar ao máximo grandes interrup̧̧ões. Porém sempre que se fazia necessário parar uma concretagem procurava-se interrompê-la em uma mesma região para todos os pavimentos, estabelecendo-se então uma junta sempre no mesmo lugar. Esse procedimento é recomendado pela construtora para todas as suas obras.

Após o início de pega do concreto, começava o processo de cura, molhando-se as lajes no instante em que o concreto apresentasse um início de endurecimento o que se prolongava por um periodo de três dias. Todavia, o processo de cura úmida só atingia as lajes, pois os pilares não eram molhados e as vigas recebiam um quinhão de molhagem proveniente apenas da rega das lajes.

A fase de desforma das lajes e vigas cumpria planejamento, com retirada das escoras das vigas e das lajes de acordo com as ordens do engenheiro.

Algumas anormalidades ocorreram na obra, como informou o engenheiro. Houve a substituição do mestre de obras entre a fase do subsolo/loja; problemas de resistência com a parede estrutural da escada no pavimento da loja, sendo feito reforço estrutural posterior por firma especializada e substituição de bitolas de armadura nas vigas em balanço dos terraços.

Mediante autorização prévia do engenheiro da obra, a autora realizou o ensaio nãodestrutivo de esclerometria, com preparação prévia da superficie, na parede estrutural em questão para verificar a eficiência do reparo estrutural realizado. Porém pode-se verificar através deste, a sanidade da peça.

Os resultados coletados “in loco" são mostrados a seguir na Tabela 19 
TABELA 19 - Número de observações e porcentagens de incidências patológicas parciais para cada elemento estrutural e integral do edificio "D".

\begin{tabular}{|c|c|c|c|c|c|c|c|c|c|c|}
\hline \multirow{2}{*}{$\begin{array}{l}\text { Eemento Estrutural } \\
\text { Tipo de maniftestaçáo patológlea observada }\end{array}$} & \multicolumn{2}{|c|}{ Laje } & \multicolumn{2}{|c|}{ Viga } & \multicolumn{2}{|c|}{ Pilar } & \multicolumn{2}{|c|}{ Parede } & \multicolumn{2}{|c|}{ Total } \\
\hline & $\$$ & $\%$ & $\$$ & $\%$ & $\$$ & $\%$ & $\$$ & $\%$ & \# & $\%^{*}$ \\
\hline desaprumo & 0 & - & 0 & - & 0 & - & 0 & - & 0 & - \\
\hline torçào da forma & 0 & - & 12 & 2,50 & 3 & 1,47 & 0 & - & 15 & 1,58 \\
\hline junta de concretagen & 8 & 5,13 & 18 & 3,75 & 0 & - & 3 & 2,78 & 29 & 3,06 \\
\hline falta de limpeza das formas & 12 & 7,69 & 15 & 3,13 & 1 & 0,49 & 1 & 0,93 & 29 & 3,06 \\
\hline falta de estanqueidade das formas & 105 & 67,31 & 65 & 13,54 & 0 & - & 1 & 0,93 & 171 & 18,04 \\
\hline falta de limpeza elementos estruturais & 58 & 37,18 & 75 & 15,63 & 3 & 1,47 & 6 & 5,56 & 142 & 14,98 \\
\hline disgregaçio & 1 & 0,64 & 2 & 0,42 & 0 & - & 0 & - & 3 & 0,32 \\
\hline bichetras & 4 & 2,56 & 10 & 2,08 & 10 & 4,90 & 12 & 11,11 & 36 & 3,80 \\
\hline segregaçao do concreto & 47 & 30,13 & 133 & 27,71 & 84 & 41,18 & 86 & 79,63 & 350 & 36,92 \\
\hline falta de cobrimento de proteçao das armaduras & 64 & 41,03 & 195 & 40,63 & 6 & 2,94 & 4 & 3,70 & 269 & 28,38 \\
\hline efeito parede & 41 & 26,28 & 0 & - & 0 & - & 0 & - & 41 & 4,32 \\
\hline Falta de afinhamento horizontal ou vertical & 52 & 33,33 & 61 & 12,71 & 3 & 1,47 & 3 & 2,78 & 119 & 12,55 \\
\hline carbonatacto na superficie do concreto & 0 & - & 0 & - & 0 & - & 0 & - & 0 & - \\
\hline manchas de corrostio ou armadura corrolda & 45 & 28,85 & 4 & 0,83 & 0 & - & 0 & - & 49 & 5,17 \\
\hline fissuras de retraçăo & 0 & - & 0 & - & 0 & - & 0 & - & 0 & - \\
\hline Fissuras inc Enadas & 55 & 35,26 & 0 & - & 0 & - & 0 & - & 55 & 5,80 \\
\hline fissuras em tubulacto & 0 & - & 55 & 11,46 & 0 & - & 0 & - & 55 & 5.80 \\
\hline fissuras verticais & 0 & - & 5 & 1,04 & 0 & - & 0 & $\cdots$ & 5 & 0,53 \\
\hline deformaçáo das formas & 6 & 3,85 & 44 & 9,17 & 13 & 6,37 & 30 & 27,78 & 93 & 9,81 \\
\hline reparos nos el estrut de vido segregacós & 2 & 1,28 & 1 & 0,21 & 15 & 7,35 & 20 & 18,52 & 38 & 4,01 \\
\hline Fxhiagao & 75 & 48,08 & 0 & - & 0 & - & 0 & - & 75 & 7,91 \\
\hline eforescenclas & 75 & 48,08 & 3 & 0,63 & 0 & - & 0 & - & 78 & 8,23 \\
\hline falta de vibraçao & 17 & 10,90 & 3 & 0,63 & 0 & - & 0 & - & 20 & 2,11 \\
\hline desagregaça do concreto & 0 & - & 0 & - & 0 & - & 0 & & 0 & - \\
\hline mal posicionamento de armadura & 0 & - & 0 & - & 0 & - & 0 & - & $\mathbf{0}$ & - \\
\hline
\end{tabular}

\section{6 - EDIFÍCIO RESIDENCIAL "E"}

A inspeção do presente edificio foi realizada em meados de agosto/97.

Nesse instante constatou-se que a obra iniciada no final de 1996 encontrava-se com o subsistema estrutura concretado até a quarta laje. $O$ subsistema alvenaria já havia se iniciado, com os dois primeiros pavimentos-tipo fechados, o que não permitiu completa visualização das faces das vigas. Estas começam a ser visualizadas por completo a partir da terceira laje.

O edificio residencial está inserido em ambiente urbano e constitui-se por onze pavimentos-tipo, sendo que cada pavimento-tipo corresponde a quatro apartamentos, totalizando quarenta e quatro habitações.

A infra-estrutura da edificação compõe-se dos seguintes elementos estruturais: tubulões, blocos, vigas baldrames, vigas alavancas.

A superestrutura é constituída por: pilares, paredes, vigas, lajes nervuradas e capitéis.

A armadura de todos os elementos estruturais compõe-se de barras e fios de aço CA-50 e CA-60 com emendas por traspasses (generalizada a $40 \mathrm{~cm}$ ) quando necessárias. 
As barras foram todas armazenadas em canteiro, em local coberto, e não permaneciam por muito tempo na obra pois eram compradas conforme a necessidade de empregá-las.

Quanto ao item projeto pode-se verificar a existência dos seguintes elementos: arquitetônico, fundações, estrutural, hidráulico e elétrico. Não foram apresentados durante a inspeção o Memorial Descritivo e os sistemas de gás, telefonia, alvenarias, revestimentos, vedações, ar condicionado, entre outros, tal que permitissem verificar a interferência de todas as partes na edificação.

Ao se analisar o projeto arquitetônico, observou-se que o banheiro social é um compartimento propenso a atmosferas viciadas e condensações, pois esse não contém aberturas que propiciem ventilação e iluminação permanentes.

Quanto à postura tomada em canteiro com relação à qualidade pode-se constatar que havia controle tecnológico do concreto por parte da concreteira fornecedora. Porém, não era prática comum a anotação dos relatos ocorridos em obra, tampouco o controle dos outros materiais dos outros subsistemas.

Em relação ao aço, não foi efetuado nenhum tipo de ensaio em laboratório. Todavia, em obra, havia o controle das barras no ato de sua utilização (verificação de bitola).

Durante a execução não houve rotatividade de mão-de-obra nem serviços subempreitados, pois todos os funcionários são contratados da construtora.

As formas foram compostas por material compensado resinado plastificado, produzidas no próprio canteiro de obras. Havia apenas um jogo de fôrmas, de modo que montava-se um pavimento, concretava-se e, verificada a resistência do concreto, compatível com a solicitação, procedia-se à desmoldagem dos elementos estruturais para aplicação no próximo pavimento. Assim era, continuamente, para as vigas e finalmente para as lajes. A pretensão era utilizar o mesmo jogo de fồrmas por aproximadamente quinze vezes. A partir dai seriam substituídas conforme suas condições de uso.

Após cada desforma, utilizava-se desmoldante nas fồmas para aplicá-las no próximo pavimento.

Através de informações obtidas do engenheiro da obra foram empregados elementos espaçadores para auxiliar no posicionamento da armadura. 
O concreto utilizado nos elementos estruturais foi todo fornecido por concreteira local. $\mathrm{O} \mathrm{f}_{\mathrm{ck}}$ empregado foi de $20 \mathrm{MPa}$ para todos os elementos estruturais só havendo distinção para os tubulões onde se empregou $f_{\alpha}$ de $15 \mathrm{MPa}$.

Antes do início de cada concretagem, as fôrmas recebiam limpeza final e a operação somente era liberada após a vistoria do engenheiro e do mestre, para então serem molhadas e permitirem o prosseguimento dos trabalhos.

Para a realização do adensamento do concreto foram utilizados vibradores com agulhas de $45 \mathrm{~mm}$ de diâmetro independente do elemento estrutural.

Porém sempre que se fazia necessário, procurava-se interromper a concretagem em uma mesma região para todos os pavimentos, estabelecendo-se então uma junta sempre no mesmo lugar.

Após o início de pega do concreto, seguia-se o processo de cura, molhando-se as lajes no instante em que o concreto apresentasse indícios de endurecimento, até um período de três dias. Todavia, esse critério de cura úmida causava o mesmo problema para as vigas e pilares como citados nos casos anteriores.

A fase de desforma das lajes e vigas cumpria planejamento, com retirada das escoras das vigas e das lajes de acordo com as ordens do engenheiro.

Segundo o mesmo, a partir da quinta laje ocorreu substituição de bitolas de aço diminuindo a área de armadura. Além disso, substituiu-se o mestre na transição da primeira para a segunda laje.

Os resultados coletados "in loco" são mostrados a seguir na Tabela 20. 
TABELA 20 - Número de observações e porcentagens de incidências patológicas parciais para cada elemento estrutural $\mathbf{e}$ integral do edificio "E".

\begin{tabular}{|c|c|c|c|c|c|c|c|c|c|c|}
\hline \multirow{2}{*}{$\begin{array}{l}\text { Eemento Estrutural } \\
\text { Tipo de manifestaçao patológica observada }\end{array}$} & \multicolumn{2}{|c|}{ Laje } & \multicolumn{2}{|c|}{ Viga } & \multicolumn{2}{|c|}{ Pilar } & \multicolumn{2}{|c|}{ Parede } & \multicolumn{2}{|c|}{ Total } \\
\hline & $\$$ & $\%$ & $\$$ & $\%$ & $\$$ & $\%$ & \$ & $\%$ & $\#$ & $\%$ \\
\hline desaprumo & 0 & - & 0 & - & 0 & - & 0 & - & 0 & - \\
\hline torçao da forma & 0 & $=$ & 0 & $=$ & 0 & $=$ & 0 & $=$ & 0 & - \\
\hline junta de concretagem & 0 & 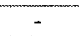 & 1 & 0,53 & 0 & - & 0 & $\because$ & 1 & 0,24 \\
\hline falta de inpeza das formas & 3 & 8,57 & 15 & 7,94 & 3 & 2,14 & 2 & 3,57 & 23 & 5,48 \\
\hline falta de estanqueidade das formas & 15 & 42,86 & 72 & 38,10 & 0 & $\cdot$ & 13 & 23,21 & 100 & 23,81 \\
\hline falka de limpeza elementos estruturals & 0 & - & 0 & - & 0 & - & 0 & - & 0 & 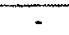 \\
\hline disgregacto & 0 & - & 0 & - & 0 & - & 0 & - & 0 & - \\
\hline bicheiras & 0 & - & 5 & 2,65 & 15 & 10,71 & 6 & 10,71 & 26 & 6,19 \\
\hline segregafáo do concre to & 12 & 34,29 & 56 & 29,63 & 48 & 34,29 & 36 & 64,29 & 152 & 36,19 \\
\hline falta de cobrimento de proteçáo das armaduras & 16 & 45,71 & 96 & 50,79 & 11 & 7,86 & 8 & 14,29 & 131 & 31,19 \\
\hline efelto pare de & 12 & 34,29 & 0 & - & 0 & - & 0 & - & 12 & 2,86 \\
\hline falla de aluhamento hortzontal ou vertical & 3 & 8,57 & 16 & 8,47 & 9 & 6,43 & 11 & 19,64 & 39 & 9,29 \\
\hline carbonataça na supe ficie de concreto & 0 & - & 0 & - & 0 & - & 0 & - & 0 & - \\
\hline manchas de corrosalo ou armadura corrolda & 0 & - & 1 & 0,53 & 0 & - & 1 & 1,79 & 2 & 0,48 \\
\hline fissuras de retraçáo & 0 & - & 0 & - & 0 & - & 0 & - & 0 & - \\
\hline fissuras inclinadas & 0 & $\cdot$ & 0 & - & 0 & - & 0 & - & 0 & - \\
\hline fissuras em tubulacto & 0 & - & 0 & - & 0 & - & 0 & - & 0 & - \\
\hline fissuras verticais & 0 & - & 0 & - & 0 & - & 0 & - & 0 & $=$ \\
\hline deformaço das formas & 10 & 28,57 & 23 & 12,17 & 11 & 7,86 & 17 & 30,36 & 61 & 14,52 \\
\hline reparos nos el. estrut. devido segregaçoes & 0 & - & 0 & - & 4 & 2,86 & 0 & - & 4 & 0,95 \\
\hline Exivlaça & 0 & - & 0 & - & 0 & - & 0 & - & 0 & - \\
\hline eflorescénclas & 0 & - & 0 & - & 0 & - & 0 & - & 0 & - \\
\hline falta de vibraçao & 14 & 40,00 & 0 & - & 0 & - & 0 & - & 14 & 3,33 \\
\hline desagregaçao do concreto & 0 & - & 0 & - & 0 & - & 0 & - & 0 & - \\
\hline
\end{tabular}

\section{7 - EDIFÍCIO RESIDENCIAL "F"}

A inspeção do presente edificio foi realizada em meados de outubro/97.

Nesse instante constatou-se que a obra iniciada em janeiro de 1990 encontrava-se paralisada desde janeiro de 1993. Seu subsistema estrutura continuava inacabado, estando concretado até a terceira laje. Os outros subsistemas não foram iniciados.

O edifício residencial está inserido em ambiente urbano e seu projeto inicial constitui-se por nove pavimentos-tipo, térreo sob pilotis e pavimento de casa de máquinas. Cada pavimento-tipo corresponde a dois apartamentos, totalizando dezoito habitações.

A infra-estrutura da edificação compõe-se dos seguintes elementos estruturais: tubulões, blocos, vigas baldrames, vigas alavancas.

A superestrutura é constituída por: pilares, vigas e lajes maciças.

A armadura de todos os elementos estruturais compõe-se de barras e fios de aço CA-50 e CA-60 com emendas por traspasses quando necessárias. As barras foram todas armazenadas em canteiro, em local descoberto, em contato direto com o solo. Nessa obra, diferente das outras, a armadura foi comprada no início da construção, permanecendo por muito tempo no canteiro desprotegida. 
Quanto ao item projeto pode-se verificar a existência dos seguintes elementos: arquitetônico, estrutural, hidráulico e elétrico. Não foram apresentados durante a inspeção - Memorial Descritivo e os sistemas de fundações, gás, telefonia, alvenarias, revestimentos, vedações, ar condicionado, etc., tal que permitissem verificar a interferência de todas as partes na edificação.

Quanto à postura tomada em canteiro com relação à qualidade, pôde-se constatar que não houve controle tecnológico nem do concreto nem das armaduras. Não era prática comum a anotação dos relatos ocorridos em obra.

Em relação ao aço, não foram efetuados ensaios em laboratório. Inexistiu também o controle das barras em campo no ato de sua utilização (amostragem por lotes, verificação de bitola, por exemplo).

Durante a execução não houve rotatividade de mão-de-obra, pois a obra foi iniciada por construtora e os funcionários eram da mesma. Todavia, houve serviços de subempreita de carpintaria e posteriormente seriam também subempreitados os subsistemas de hidráulica e elétrica.

As fôrmas foram compostas por material compensado resinado e produzidas no próprio canteiro de obras. Havia apenas um jogo de fôrmas, de modo que montava-se um pavimento, concretava-se e, verificada a resistência do concreto, compatível com a solicitação, procedia-se à desmoldagem dos elementos estruturais para aplicação no próximo pavimento. Assim era, sucessivamente, para os pilares, vigas e finalmente para as lajes.

O mesmo jogo de fồmas foi utilizado até a terceira laje, e, na época da vistoria, ele ainda se encontrava na obra, aparelhado no piso do segundo pavimento, em estado precário.

Após cada desforma, limpavam-se as fôrmas e aplicava-se desmoldante para se garantir acabamento nos elementos estruturais, além de preservá-las antes de serem montadas novamente no próximo pavimento.

Através de informações obtidas do engenheiro da obra, foram empregados elementos espaçadores do tipo pastilhas nos pilares para auxiliar no posicionamento da armadura. 
$O$ concreto utilizado nos elementos estruturais foi todo fornecido por concreteira local. $\mathrm{O} \mathrm{f}_{\mathrm{ck}}$ empregado foi de 18MPa para todos os elementos estruturais, só havendo distinção para os tubulões onde se empregou $f_{c k}$ de $15 \mathrm{MPa}$.

Antes de cada concretagem, as fồmas recebiam limpeza final e a operação somente era liberada após a vistoria do engenheiro e do mestre, para então serem molhadas e permitirem o início dos trabalhos.

Para realização do adensamento do concreto, foram utilizados vibradores com agulhas de $37 \mathrm{~mm}$ para todos elementos estruturais.

A concretagem sempre cumpria um horário, começando pela manhã. Devido ao pequeno porte da construção, conseguia-se acabar o trabalho no mesmo dia não ocorrendo juntas de concretagem.

Logo depois do começo da pega do concreto, por volta de duas horas após o início da concretagem, iniciava-se o processo de cura, molhando-se as lajes no instante em que o concreto apresentasse um início de endurecimento. $\mathrm{O}$ procedimento se seguia por um período de dois dias. Todavia, o processo de cura úmida só era dirigido às lajes, ficando os pilares e vigas sem molhagem.

A fase de desforma das lajes e vigas cumpria o planejamento, com retirada das escoras das vigas e das lajes, de acordo com as ordens do engenheiro. De acordo com as necessidades de montagem do próximo pavimento, eram desmontados os elementos estruturais.

Como o fator tempo não era o mais importante para a obra, desformava-se os pilares e subseqüentemente vigas e lajes, aproximadamente após um mês de concretados. Com isso não se fazia reescoramento.

Segundo o engenheiro da construtora administradora da obra, a única anormalidade ocorrida durante a execução foi a falta de dinheiro do investidor que determinou a paralisação desta. Até o momento da visita ao canteiro não havia previsão de retomada das atividades.

Os resultados coletados “in loco" são mostrados a seguir na Tabela 21. 
TABELA 21 - Número de observações e porcentagens de incidências patológicas parciais para cada elemento estrutural e integral do edifício " $F$ ".

\begin{tabular}{|c|c|c|c|c|c|c|c|c|}
\hline \multirow{2}{*}{$\begin{array}{l}\text { Eemento Estrutural } \\
\text { Tipo de manifestação patológica observada }\end{array}$} & \multicolumn{2}{|c|}{ Laje } & \multicolumn{2}{|c|}{ Viga } & \multicolumn{2}{|c|}{ Pilar } & \multicolumn{2}{|c|}{ Total } \\
\hline & $\$$ & $\%$ & $\$$ & $\%$ & $\$$ & $\%$ & $\#$ & $\% *$ \\
\hline desaprumo & 0 & - & 0 & - & 3 & 3,75 & 3 & 1,09 \\
\hline torção da fórma & 0 & - & 0 & - & 0 & - & 0 & - \\
\hline junta de concretagem & 0 & - & 2 & 1,67 & 6 & 7,50 & 8 & 2,90 \\
\hline falta de limpeza das formas & 10 & 13,16 & 13 & 10,83 & 1 & 1,25 & 24 & 8,70 \\
\hline falta de estanqueidade das formas & 0 & - & 0 & - & 0 & - & $\mathbf{0}$ & - \\
\hline falta de limpeza elementos estruturais & 1 & 1,32 & 1 & 0,83 & 0 & $=$ & 2 & 0,72 \\
\hline disgregaçāo & 5 & 6,58 & 16 & 13,33 & 1 & 1,25 & 22 & 7,97 \\
\hline bicheiras & 0 & - & 1 & 0,83 & 3 & 3,75 & 4 & 1,45 \\
\hline segregaçäo do concreto & 5 & 6,58 & 7 & 5,83 & 49 & 61,25 & 61 & 22,10 \\
\hline falta de cobrimento de proteçáo das armaduras & 22 & 28,95 & 48 & 40,00 & 2 & 2,50 & 72 & 26,09 \\
\hline efeito parede & 2 & 2,63 & 0 & $=$ & 0 & - & 2 & 0,72 \\
\hline falta de alinhamento horizontal ou vertical & 42 & 55,26 & 15 & 12,50 & 1 & 1,25 & 58 & 21,01 \\
\hline carbonataçāo na superficie de concreto & 56 & 73,68 & 120 & 100,00 & 80 & 100,00 & 256 & 92,75 \\
\hline manchas de corrosāo ou armadura corroída & 7 & 9,21 & 0 & - & 2 & 2,50 & 9 & 3,26 \\
\hline fissuras de retração & 0 & - & 3 & 2,50 & 36 & 45,00 & 39 & 14,13 \\
\hline fissuras inclinadas & 11 & 14,47 & 14 & 11,67 & 0 & - & 25 & 9,06 \\
\hline fissuras em tubulação & 0 & - & 12 & 10,00 & 0 & - & 12 & 4,35 \\
\hline fissuras verticais & 0 & - & 13 & 10,83 & 0 & - & 13 & 4,71 \\
\hline deformaçāo das fôrmas & 0 & - & 1 & 0,83 & 4 & 5,00 & 5 & 1,81 \\
\hline reparos nos el. estrut. devido segregaçōes & 5 & 6,58 & 0 & - & 2 & 2,50 & 7 & 2,54 \\
\hline lixiviação & 3 & 3,95 & 13 & 10,83 & 2 & 2,50 & 18 & 6,52 \\
\hline eflorescências & 5 & 6,58 & 11 & 9,17 & 1 & 1,25 & 17 & 6,16 \\
\hline falta de vibração & 3 & 3,95 & 0 & - & 0 & - & 3 & 1,09 \\
\hline desagregaçāo do concreto & 0 & - & 8 & 6,67 & 0 & - & 8 & 2,90 \\
\hline
\end{tabular}

\section{8 - EDIFICIO RESIDENCIAL “ $\mathbf{G}$ ”}

A inspeção do presente edificio foi realizada em meados de julho/97.

A obra que se iniciou em meados de 1993 encontrava-se paralisada com a superestrutura no décimo-quinto pavimento e o subsistema alvenaria das paredes externas no décimo-segundo pavimento.

O edificio residencial está inserido em ambiente urbano e se constituirá por dezoito pavimentos, sendo que cada pavimento-tipo corresponde a quatro apartamentos, totalizando setenta e duas habitações.

A infra-estrutura da edificação compõe-se dos seguintes elementos estruturais: tubulões, blocos e vigas baldrames.

A superestrutura é constituída por: pilares, paredes, vigas, lajes maciças, lajes nervuradas e capitéis.

A armadura de todos os elementos estruturais compõe-se de barras e fios de aço CA-50 e CA-60, com emendas por traspasses quando necessárias. 
A ferragem dos elementos estruturais vinha para a obra da central da construtora que era sediada em outro município. Sendo assim não havia armazenamento de barras no canteiro, pois já chegavam na obra prontas para serem usadas.

Quanto ao item projeto pode-se verificar a existência dos seguintes elementos: arquitetônico, estrutural, alvenaria, sistema hidráulico (água fria, quente, esgoto, incêndio), os sistemas de gás, elétrico, telefonia e revestimentos, locação de estacas e pilares, detalhamentos dos painéis das fôrmas, escoramento e travamento das vigas e distribuição de longarinas e barrotes. Não foi apresentado durante a inspeção o Memorial Descritivo.

Quanto à postura tomada em canteiro com relação à qualidade, pôde-se constatar que havia controle tecnológico do concreto bem como dos materiais dos outros subsistemas. No caso dos subsistemas alvenaria, hidráulica e elétrica, o sistema empregado foi desenvolvido pela própria construtora visando exatamente o fator qualidade. Apesar de não ter sido apresentado durante a inspeção, era prática comum a anotação dos relatos ocorridos no diário de obras.

Em relação ao aço, foram realizados alguns ensaios em laboratório para se comprovar sua qualidade. No canteiro havia somente a confirmação das ferragens dos elementos estruturais, pois como a ferragem já chegava pronta, o eventual controle da barras era feito na central de ferragens da construtora.

Durante a execução não houve rotatividade de mão-de-obra, pois havia funcionários designados para todas as fases de todos os subsistemas da obra.

As fồmas foram compostas por material compensado resinado e plastificado segundo projeto de corte e montagem dos painéis e produzidas no próprio canteiro de obras.

Havia apenas um jogo de fôrmas de modo que montava-se um pavimento, concretava-se e, verificada a resistência do concreto, compatível com a solicitação, procedia-se à desmoldagem dos elementos estruturais, para aplicação no próximo pavimento. Assim era, sucessivamente, para as vigas, pilares e finalmente para as lajes.

O reaproveitamento até então tinha sido completo, ou seja, a superestrutura chegou até o décimo-quinto pavimento com o mesmo jogo de fồrmas. Foram substituídas apenas partes dos painéis que já não apresentavam condições de uso. 
Após cada desforma, limpavam-se as fồrmas e aplicava-se desmoldante no traço 1:3 (desmoldante:água) para se garantir acabamento nos elementos estruturais além de preservá-las para a reutilização.

Através de informações obtidas do mestre de obras verificou-se que foram empregados elementos espaçadores do tipo pastilhas na vigas e principalmente nas nervuras das lajes e mangotes altos no momento da concretagem dos capitéis. Para a armadura negativa das lajes empregaram "caranguejos". Para os pilares usaram-se pastilhas espaçadoras e grampos para evitar a movimentação interna da ferragem e que a mesma encostasse nas superficies das fồmas

O concreto utilizado nos elementos estruturais foi todo fornecido por concreteira local. Para os pilares e blocos empregou-se $f_{\text {ck }}$ de $25 \mathrm{MPa}$ com brita 1 e 2 , abatimento $70 \pm 10 \mathrm{~mm}$. Para as vigas e lajes empregou-se $\mathrm{f}_{\mathrm{ck}}$ de $25 \mathrm{MPa}$ com brita 1 , abatimento $70 \pm 10 \mathrm{~mm}$ e para os tubulões o $\mathrm{f}_{\mathrm{ck}}$ empregado foi de 13,5MPa com brita 1 e 2 e abatimento $70 \pm 10 \mathrm{~mm}$

Antes de cada concretagem, as fôrmas recebiam limpeza final e a operação somente era liberada após a vistoria do engenheiro e do mestre, para então serem molhadas e permitirem o início dos trabalhos.

Para realização do adensamento do concreto, foram utilizados vibradores com agulhas de $25 \mathrm{~mm}$ e $37 \mathrm{~mm}$. Para os capitéis utilizava-se agulha de $37 \mathrm{~mm}$. Para os elementos estruturais restantes, agulha de $25 \mathrm{~mm}$.

As concretagens começavam impreterivelmente no início do dia. Caso não houvesse tempo suficiente para se concluir o trabalho num mesmo dia, no seguinte retomava-se a concretagem por esse trecho, tomando-se o cuidado de sempre interromper uma concretagem no mesmo ponto de possíveis juntas em pavimentos anteriores.

Após o início de pega do concreto, iniciava-se o processo de cura, molhando todos os elementos estruturais por um período de sete dias. Essa rega dava-se durante todo o dia, de modo a sempre garantir uma lâmina de água na superficie.

Tanto o escoramento e travamento quanto o descimbramento dos elementos estruturais seguiam religiosamente os projetos elaborados para essa fase.

Segundo o mestre, a obra tinha um engenheiro responsável e outros quatro engenheiros que trabalhavam em esquema de rodízio. Com isso a obra sempre contava com a presença de um engenheiro. 
Quanto ao corpo de profissionais restantes, desde o início da obra até o momento da paralisação dos trabalhos, já haviam passado pela presente obra outros quatro mestres antes do atual, somando cinco profissionais com esse cargo de inspeção.

A construtora responsável pela obra começou a enfrentar dificuldades financeiras causando descontentamento entre os funcionários. Tal fato pôde ser notado visivelmente conforme andamento da obra. A construção foi paralisada em meados de junho de 1997 sem previsão de retomada dos serviços até o momento.

Os resultados coletados "in loco" são mostrados a seguir na Tabela 22.

TABELA 22 - Número de observações e porcentagens de incidências patológicas parciais para cada elemento estrutural e integral do edificio “ $G$ ”.

\begin{tabular}{|c|c|c|c|c|c|c|c|c|}
\hline \multirow{2}{*}{$\begin{array}{l}\text { PAVMENTO } \\
\text { Tipo de manifestaçäo patológica observada }\end{array}$} & \multicolumn{2}{|c|}{ Laje } & \multicolumn{2}{|c|}{ Viga } & \multicolumn{2}{|c|}{ Pilar } & \multicolumn{2}{|c|}{ Total } \\
\hline & $\$$ & $\%$ & $\$$ & $\%$ & $\$$ & $\%$ & $\#$ & $\%^{*}$ \\
\hline desaprumo & 0 & - & 1 & 0,28 & 2 & 0,51 & 3 & 0,38 \\
\hline tor ção da fôrma & 0 & - & 12 & 3,33 & 2 & 0,51 & 14 & 1,76 \\
\hline junta de concretagem & 1 & 2,22 & 8 & 2,22 & 0 & - & 9 & 1,13 \\
\hline falta de limpeza das fórmas & 0 & - & 20 & 5,56 & 1 & 0,26 & 21 & 2,64 \\
\hline falta de estanqueidade das fórmas & 34 & 75,56 & 16 & 4,44 & 0 & - & 50 & 6,29 \\
\hline falta de limpeza nos elementos estruturais & 3 & 6,67 & 24 & 6,67 & 12 & 3,08 & 39 & 4,91 \\
\hline disgregação & 10 & 22,22 & 39 & 10,83 & 18 & 4,62 & 67 & 8,43 \\
\hline bicheiras & 6 & 13,33 & 1 & 0,28 & 29 & 7,44 & 36 & 4,53 \\
\hline segregaçäo do concreto & 82 & 182,22 & 16 & 4,44 & 95 & 24,36 & 193 & 24,28 \\
\hline falta de cobrimento de proteçāo das armaduras & 17 & 37,78 & 150 & 41,67 & 59 & 15,13 & 226 & 28,43 \\
\hline efeito parede & 3 & 6,67 & 0 & - & 0 & - & 3 & 0,38 \\
\hline falta de alinhamento horizontal ou vertical & 24 & 53,33 & 97 & 26.94 & 19 & 4,87 & 140 & 17,61 \\
\hline carbonatação na superficie de concreto & 49 & 108,89 & 5 & 1,39 & 175 & 44,87 & 229 & 28,81 \\
\hline manchas de corrostao ou armadura corroida & 37 & 82,22 & 176 & 48,89 & 61 & 15,64 & 274 & 34,47 \\
\hline fissuras de retração & 0 & - & 0 & - & 0 & - & 0 & - \\
\hline fissuras inclinadas & 38 & 84,44 & 0 & - & 0 & - & 38 & 4,78 \\
\hline fissuras em tubulação & 0 & - & 0 & - & 0 & - & 0 & - \\
\hline fissuras verticais & 0 & - & 0 & - & 0 & - & 0 & - \\
\hline deformaçāo das formas & 1 & 2,22 & 57 & 15,83 & 17 & 4,36 & 75 & 9,43 \\
\hline reparos nos el. es trut. devido segregaçōes & 17 & 37,78 & 0 & - & 16 & 4,10 & 33 & 4,15 \\
\hline lixiviação & 49 & 108,89 & 10 & 2,78 & 1 & 0,26 & 60 & 7,55 \\
\hline eflorescências & 49 & 108,89 & 10 & 2,78 & 1 & 0,26 & 60 & $\mathbf{7 , 5 5}$ \\
\hline falta de vibração & 0 & - & 0 & - & 0 & - & 0 & - \\
\hline desagregação do concreto & 0 & - & 0 & - & 0 & - & 0 & - \\
\hline mal posicionamento de armadura & 9 & 20,00 & 11 & 3,06 & 7 & 1,79 & 27 & 3,40 \\
\hline
\end{tabular}

\section{9 - EDIFICIO RESIDENCIAL “ $\mathrm{H}$ ”}

A inspeção do presente edificio foi realizada em meados de julho/97.

A obra que se iniciou em meados de 1994 encontrava-se paralisada com a superestrutura pronta chegando ao vigésimo-segundo pavimento juntamente com o subsistema alvenaria. 
O edificio residencial está inserido em ambiente urbano se constituirá por vinte pavimentos-tipo e duas coberturas. Cada pavimento tipo contém dois apartamentos, totalizando quarenta e duas habitações.

A infra-estrutura da edificação compõe-se dos seguintes elementos estruturais: tubulões, blocos e vigas baldrames.

A superestrutura é constituída por: pilares, paredes, vigas e lajes maciças.

A armadura de todos os elementos estruturais compõe-se de barras e fios de aço CA-50 e CA-60, com emendas por traspasses quando necessárias.

A ferragem dos elementos estruturais vinha para a obra da central da construtora que era sediada em outro município. Sendo assim, não havia armazenamento de barras no canteiro, já que chegavam na obra prontas para serem usadas.

Quanto ao item projeto, pôde-se verificar a existência dos seguintes elementos: arquitetônico, estrutural, alvenaria, sistema hidráulico (água fria, quente, esgoto, incêndio), sistemas de gás, elétrico, telefonia e revestimentos, locação de estacas e pilares, detalhamentos dos painéis das fôrmas, escoramento e travamento das vigas e distribuição de longarinas e barrotes. Não foi apresentado durante a inspeção o Memorial Descritivo.

Quanto à postura tomada em canteiro com relação à qualidade, pôde-se constatar que havia controle tecnológico do concreto bem como dos outros materiais dos outros subsistemas. No caso dos subsistemas alvenaria, hidráulica e elétrica, o sistema empregado foi desenvolvido pela própria construtora visando exatamente o fator qualidade. Apesar de não ter sido apresentado durante a inspeção, era prática comum a anotação dos relatos ocorridos no diário de obras.

Em relação ao aço, foram realizados alguns ensaios em laboratório para se comprovar sua qualidade. No canteiro havia somente a confirmação das ferragens dos elementos estruturais pois a ferragem já chegava pronta. $\mathrm{O}$ eventual controle das barras era feito na central de ferragem da construtora.

Durante a execução não houve rotatividade de mão-de-obra pois havia funcionários designados para todas as fases de todos os subsistemas da obra.

As fôrmas foram compostas por material compensado resinado e plastificado segundo projeto de corte e montagem dos painéis e produzidas no próprio canteiro de obras. 
Havia apenas um jogo de fôrmas, de modo que montava-se um pavimento, concretava-se e, verificada a resistência do concreto, compatível com a solicitação, procedia-se à desmoldagem dos elementos estruturais, para aplicação no próximo pavimento. Assim era, sucessivamente, para as vigas, pilares e finalmente para as lajes.

O reaproveitamento das fồrmas foi de $70 \%$, ou seja, até o décimo-sexto pavimento empregou-se o jogo de fôrmas iniciais. A partir daí, utilizou-se um novo jogo.

Após cada desforma, limpavam-se as fôrmas e aplicava-se desmoldante no traço 1:3 (desmoldante:água) para se garantir acabamento nos elementos estruturais além de preservá-las para serem reutilizadas.

Através de informações obtidas do mestre de obras verificou-se que foram empregados elementos espaçadores do tipo pastilhas na vigas e lajes além de caranguejos entre as armaduras positiva e negativa destas. Para os pilares, usou-se pastilhas e grampos para evitar a movimentação interna da ferragem e que a mesma encostasse nas superficies das fồrmas.

O concreto utilizado nos elementos estruturais foi todo fornecido por concreteira local. Para os pilares, vigas, lajes e blocos empregou-se $f_{c k}$ de $25 \mathrm{MPa}$ com brita 1 e 2 , abatimento $55 \pm 10 \mathrm{~mm}$. Para os tubulões o $\mathrm{f}_{\mathrm{ck}}$ empregado foi de 13,5MPa com brita 1 e 2 e abatimento $55 \pm 10 \mathrm{~mm}$.

Antes de cada concretagem, as fôrmas recebiam limpeza final e a operação somente era liberada após a vistoria do engenheiro e do mestre, para então serem molhadas e permitirem o início dos trabalhos.

Para realização do adensamento do concreto, foram utilizados vibradores com agulhas de $37 \mathrm{~mm}$.

Não houve necessidade de criar juntas de concretagem pois sempre se conseguiu concretar um pavimento no mesmo dia.

O processo de cura começava aproximadamente quatro horas depois do início da concretagem sendo lajes, vigas e pilares molhados três vezes ao dia por um período de três dias.

A desforma dos pilares e vigas acontecia quando o concreto contava com sete dias de idade. Para as lajes, essa fase se dava quando o concreto completava quatorze dias de idade. 
Tanto o escoramento e travamento quanto o descimbramento das lajes seguiam religiosamente os projetos elaborados para essa fase, assim como o escoramento e o travamento das vigas. $\mathrm{O}$ descimbramento era realizado segundo instruções do mestre, começando a retirada das escoras das laterais para o centro do vão. $O$ mesmo ocorria com os pilares.

Segundo o mestre, a obra tinha um engenheiro responsável e outros quatro engenheiros que trabalhavam em esquema de rodízio. Com isso a construção sempre contava com a presença de engenheiro.

Quanto ao corpo de profissionais restantes, a obra estava com seu segundo mestre na obra até o momento da paralisação das atividades no canteiro.

A construtora responsável pela obra começou a enfrentar dificuldades financeiras causando descontentamento entre os funcionários. Tal fato, aparentemente, não implicou maiores danos à obra pois nessa fase a superestrutura já estava praticamente pronta $\mathrm{e}$ chapiscada, só restando a conclusão das coberturas. A obra foi paralisada em meados de julho de 1997 sem previsão de retomada dos serviços até o momento.

Os resultados coletados "in loco" são mostrados a seguir na Tabela 23.

TABELA 23 - Número de observações e porcentagens de incidências patológicas parciais para cada elemento estrutural $\mathrm{e}$ integral do edificio "H".

\begin{tabular}{|c|c|c|c|c|c|c|c|c|c|c|}
\hline \multirow{2}{*}{$\begin{array}{l}\text { Bemento Estrutural } \\
\text { Tipo de manifestafáo patologica observada }\end{array}$} & \multicolumn{2}{|c|}{ Laje } & \multicolumn{2}{|c|}{ Viga } & \multicolumn{2}{|c|}{ Pillar } & \multicolumn{2}{|c|}{ Parede } & \multicolumn{2}{|c|}{ Total } \\
\hline & $\$$ & $\%$ & $\$$ & $\%$ & $\$$ & $\%$ & $\$$ & $\%$ & \# & $\% *$ \\
\hline desaprumo & 0 & - & 0 & - & 0 & - & 0 & - & 0 & - \\
\hline torçao da forma & 0 & - & 14 & 1,63 & 0 & - & 0 & - & 14 & 0,83 \\
\hline junta de concretagem & 11 & 3,08 & 10 & 1,16 & 0 & $\cdot$ & 0 & - & 21 & 1,25 \\
\hline falta de limpeza das formas & 17 & 4,76 & 36 & 4,18 & 17 & 13,49 & 28 & 8,33 & 98 & 5,83 \\
\hline falta de estanqueidade das formas & 124 & 34,73 & 262 & 30,43 & 1 & 0,79 & 6 & 1,79 & 393 & 23,39 \\
\hline falta de limpeza nos elementos estruturais & 32 & 8,96 & 5 & 0,58 & 9 & 7,14 & 9 & 2,68 & 55 & 3,27 \\
\hline disgregacáo & 0 & - & 72 & 8,36 & 5 & 3,97 & 0 & - & 77 & 4,58 \\
\hline bicheiras & 0 & - & 4 & 0,46 & 1 & 0,79 & 7 & 2,08 & 12 & 0,71 \\
\hline segregaça do concreto & 20 & 5,60 & 31 & 3,60 & 25 & 19,84 & 62 & 18,45 & 138 & 8,21 \\
\hline falta de cobrimento de proteçáo das armaduras & 75 & 21,01 & 522 & 60,63 & 7 & 5,56 & 5 & 1,49 & 609 & 36,25 \\
\hline efeito parede & 71 & 19,89 & 0 & - & 0 & $\therefore$ & 0 & - & 71 & 4,23 \\
\hline falla de alinhamento horkontal ou vertical & 72 & 20,17 & 82 & 9,52 & 32 & 25,40 & 23 & 6,85 & 209 & 12,44 \\
\hline carbonataça na superficie de concreto & 130 & 36,41 & 1 & 0,12 & 84 & 66,67 & 0 & - & 215 & 12,80 \\
\hline manchas de corrosăo ou armadura corroida & 16 & 4,48 & 34 & 3,95 & 6 & 4,76 & 9 & 2,68 & 65 & 3,87 \\
\hline fissuras de retraçao & 0 & $=$ & 5 & 0,58 & 0 & - & 0 & - & 5 & 0,30 \\
\hline fissuras inclinadas & 125 & 35,01 & 0 & - & 0 & - & 0 & - & 125 & 7,44 \\
\hline fissuras em tubulacto & 0 & - & 59 & 6,85 & 0 & - & 0 & - & 59 & 3,51 \\
\hline fissuras verticais & 0 & - & 28 & 3.25 & 0 & - & 0 & - & 28 & 1,67 \\
\hline deformaçăo das formas & 30 & 8,40 & 217 & 25,20 & 43 & 34,13 & 38 & 11,31 & 328 & 19,52 \\
\hline reparos nos el. estrut. devido segregacces & 3 & 0,84 & 4 & 0,46 & 7 & 5,56 & 8 & 2,38 & 22 & 1,31 \\
\hline Ixiviactao & 130 & 36,41 & 1 & 0,12 & 0 & - & 0 & - & 131 & 7,80 \\
\hline eflorescencias & 122 & 34,17 & 0 & - & 0 & - & 0 & - & 122 & 7,26 \\
\hline falta de vibracáo & 18 & 5,04 & 0 & - & 0 & - & 0 & - & 18 & 1,07 \\
\hline desagregacka do concreto & 0 & - & 0 & - & 0 & - & 0 & - & 0 & - \\
\hline
\end{tabular}




\subsection{0 - EDIFÍCIO RESIDENCIAL “ I "}

A inspeção do presente edificio foi realizada em meados de agosto/97.

A obra que se iniciou no segundo semestre de 1993 encontrava-se paralisada com a superestrutura concretada até o décimo-sétimo pavimento, juntamente com o subsistema alvenaria (pronto até o décimo-quarto pavimento).

O edificio residencial está inserido em ambiente urbano e se constituirá por dezoito pavimentos-tipo e uma cobertura. Cada pavimento-tipo contém um apartamento, totalizando dezenove habitações.

A infra-estrutura da edificação compõe-se dos seguintes elementos estruturais: tubulões, blocos, vigas baldrames e vigas alavanca.

A superestrutura é constituída por: pilares, paredes, vigas e lajes maciças

A armadura de todos os elementos estruturais compõe-se de barras e fios de aço CA-50 e CA-60, com emendas por traspasses quando necessárias.

A ferragem dos elementos estruturais vinham para a obra da central da construtora que era sediada em outro município. Sendo assim não havia armazenamento de barras no canteiro, pois já chegavam na obra prontas para serem usadas.

Quanto ao item projeto pode-se verificar a existência dos seguintes elementos: arquitetônico, estrutural, alvenaria, sistema hidráulico (água fria, quente, esgoto, incêndio), sistemas de gás, elétrico, telefonia e revestimentos, locação de estacas e pilares, detalhamentos dos painéis das fồrmas, escoramento e travamento das vigas e distribuição de longarinas e barrotes. Não foi apresentado durante a inspeção o Memorial Descritivo.

Quanto à postura tomada em canteiro com relação à qualidade, pôde-se constatar que havia controle tecnológico do concreto bem como dos materiais dos outros subsistemas. No caso dos sub-sistemas alvenaria, hidráulica e elétrica o sistema empregado foi desenvolvido pela própria construtora, visando exatamente o fator qualidade. Apesar de não ter sido apresentado durante a inspeção, era prática comum a anotação dos relatos ocorridos no diário de obras.

Em relação ao aço, foram realizados alguns ensaios em laboratório para se comprovar sua qualidade. No canteiro havia somente a confirmação das ferragens dos elementos estruturais já que a ferragem chegava pronta. $\mathrm{O}$ eventual controle da barras era feito na central de ferragem da construtora. 
Durante a execução não houve rotatividade de mão-de-obra, pois havia funcionários designados para as fases de todos os subsistemas da obra.

As fồrmas foram compostas por material compensado resinado e plastificado segundo projeto de corte e montagem dos painéis e produzidas no próprio canteiro de obras.

Havia apenas um jogo de fôrmas, de modo que montava-se um pavimento, concretava-se e, verificada a resistência do concreto, compatível com a solicitação, procedia-se à desmoldagem dos elementos estruturais para aplicação no próximo pavimento. Assim era, sucessivamente, para as vigas, pilares e finalmente para as lajes.

O reaproveitamento das fôrmas foi de $100 \%$ sendo substituídos apenas painéis parciais, que já não apresentavam condições de uso.

Após cada desforma, limpavam-se as fôrmas e aplicava-se desmoldante no traço 1:3 (desmoldante:água) para se garantir acabamento nos elementos estruturais além de preservar as fồrmas para serem novamente montadas.

Através de informações obtidas do mestre de obras, verificou-se que foram empregados elementos espaçadores do tipo pastilhas na vigas e lajes, além de caranguejos entre as armaduras positiva e negativa destas. Para os pilares usaram-se pastilhas e grampos para evitar a movimentação interna da ferragem e evitar que a mesma encostasse nas superficies das fồmas.

O concreto utilizado nos elementos estruturais foi todo fornecido por concreteira local. Para os pilares, vigas, lajes e blocos empregou-se $\mathrm{f}_{\mathrm{ck}}$ de $25 \mathrm{MPa}$ e para os tubulões o $f_{\mathrm{ck}}$ empregado foi de $15,0 \mathrm{MPa}$.

Antes do início de cada concretagem, as fôrmas recebiam limpeza final e a operação somente era liberada após a vistoria do engenheiro e do mestre, para então serem molhadas.

Para realização do adensamento do concreto, foram utilizados vibradores com agulhas de $25 \mathrm{~mm}$ e $37 \mathrm{~mm}$.

A princípio não houve necessidade de criar juntas de concretagem pois sempre se conseguiu concretar um pavimento no mesmo dia.

Após o início de pega do concreto, seguia-se o processo de cura. O processo começava seis horas depois do início da concretagem e levava um periodo de sete dias 
para se completar. Todos os elementos estruturais recebiam o mesmo procedimento de cura.

Realizava-se a desforma dos pilares e vigas com o concreto contando sete dias de idade. Para as lajes, esta fase se dava quando o concreto completava quatorze dias de idade.

Tanto o escoramento e travamento quanto o descimbramento das lajes seguiam religiosamente os projetos elaborados para esta fase. $\mathrm{O}$ escoramento e travamento das vigas também seguiam o projeto. Porém seu descimbramento era realizado segundo instruções do mestre, começando-se a retirada das escoras das laterais para o centro do vão. $\mathrm{O}$ mesmo ocorria com os pilares.

Segundo o mestre, a obra tinha um engenheiro responsável e outros quatro engenheiros que trabalhavam em esquema de rodizio. Com isso, a obra contava sempre com a presença de um engenheiro.

Quanto ao corpo de profissionais restantes, a obra estava com seu terceiro mestre na obra até o momento da paralisação das atividades no canteiro.

A construtora responsável pela obra começou a enfrentar dificuldades financeiras causando descontentamento entre os funcionários. Tal fato pôde ser percebido durante as visitas ao longo do andamento da construção. A obra foi paralisada em meados de junho de 1997 sem previsão de retomada dos serviços até o momento.

Os resultados coletados “in loco" são mostrados a seguir na Tabela 24. 
TABELA 24 - Número de observações e porcentagens de incidências patológicas parciais para cada elemento estrutural e integral do edificio "I".

\begin{tabular}{|c|c|c|c|c|c|c|c|c|c|c|}
\hline \multirow{2}{*}{$\begin{array}{l}\text { Eemento Estrutural } \\
\text { Tipo de manilestaçăo patológica observada }\end{array}$} & \multicolumn{2}{|c|}{ Laje } & \multicolumn{2}{|c|}{ Viga } & \multicolumn{2}{|c|}{ Pilar } & \multicolumn{2}{|c|}{ Parede } & \multicolumn{2}{|c|}{ Total } \\
\hline & $\$$ & $\%$ & $\$$ & $\%$ & $\$$ & $\%$ & $\$$ & $\%$ & \# & $\% *$ \\
\hline desapruma & 0 & - & 0 & - & 1 & 0,62 & 0 & - & 1 & 0,12 \\
\hline torçáo da forma & 0 & - & 2 & 0,51 & 3 & 1,85 & 0 & - & 5 & 0,60 \\
\hline junta de concretagem & 3 & 1,67 & 1 & 0,25 & 0 & - & 0 & - & 4 & 0,48 \\
\hline falta de limpeza das formas & 2 & 1,11 & 32 & 8,08 & 1 & 0,62 & 0 & - & 35 & 4,23 \\
\hline falta de estanqueidade das formas & 110 & 61,11 & 37 & 9,34 & 5 & 3,09 & 0 & - & 152 & 18,36 \\
\hline falta de limpeza nos elementos estruturais & 27 & 15,00 & 24 & 6,06 & 45 & 27,78 & 16 & 17,78 & 112 & 13,53 \\
\hline disgregaçao & 4 & 2,22 & 20 & 5,05 & 0 & - & 0 & - & 24 & 2,90 \\
\hline bicheiras & 2 & 1,11 & 8 & 2,02 & 5 & 3,09 & 11 & 12,22 & 26 & 3,14 \\
\hline segregacáo do concreto & 14 & 7,78 & 59 & 14,90 & 88 & 54,32 & 47 & 52,22 & 208 & 25,12 \\
\hline falta de cobrimento de proteçao das armaduras & 6 & 3,33 & 119 & 30,05 & 3 & 1,85 & 4 & 4,44 & 132 & 15,94 \\
\hline efeito parede & 1 & 0,56 & 0 & - & 0 & - & 0 & - & 1 & 0,12 \\
\hline falta de alinhamento horizontal ou vertical & 25 & 13,89 & 31 & 7,83 & 13 & 8,02 & 4 & 4,44 & 73 & 8,82 \\
\hline carbonataço na superficie de concreto & 120 & 66,67 & 6 & 1,52 & 53 & 32,72 & 0 & - & 179 & 21,62 \\
\hline manchas de corrosáo ou armadura corrolda & 11 & 6,11 & 76 & 19,19 & 2 & 1,23 & 3 & 3,33 & 92 & 11,11 \\
\hline fissuras de retraçao & 0 & $\sim$ & 0 & - & 0 & - & 0 & - & 0 & - \\
\hline ftssuras inclinadas & 107 & 59,44 & 0 & - & 0 & - & 0 & - & 107 & 12,92 \\
\hline fissuras em tubulagao & 0 & - & 0 & - & 0 & $=$ & 0 & - & 0 & - \\
\hline fissuras verticais & 0 & - & 0 & - & 0 & - & 0 & - & 0 & - \\
\hline deformaçáo das formas & 9 & 5,00 & 57 & 14,39 & 19 & 11,73 & 6 & 6,67 & 91 & 10,99 \\
\hline reparos nos el. estrut. de vido segregac oes & 9 & 5,00 & 0 & - & 6 & 3,70 & 3 & 3,33 & 18 & 2,17 \\
\hline loxiviagăo & 120 & 66,67 & 6 & 1,52 & 1 & 0,62 & 0 & - & 127 & 15,34 \\
\hline eflorescencias & 116 & 64,44 & 5 & 1,26 & 1 & 0,62 & 0 & - & 122 & 14,73 \\
\hline falta de vibraçáo & 0 & - & 0 & - & 0 & - & 0 & - & 0 & - \\
\hline desagregacáo do concreto & 0 & - & 0 & - & 0 & - & 0 & - & 0 & - \\
\hline mal posicionamento da armadura & 0 & - & 8 & 36,36 & 1 & 0,62 & 0 & - & 9 & 1,09 \\
\hline
\end{tabular}

\subsection{1 - EDIFÍCIO RESIDENCIAL “ $\mathrm{J}$ "}

A inspeção do presente edificio foi realizada em meados de outubro/97.

Nesse instante constatou-se que a obra iniciada em 1991 encontrava-se com o subsistema estrutura concluído e começava a execução do subsistema alvenaria e subsistema revestimento (aplicação de gesso sobre alvenaria).

O edificio residencial está inserido em ambiente urbano e constitui-se por onze pavimentos e duas coberturas, sendo que cada pavimento-tipo corresponde a quatro apartamentos, totalizando quarenta e seis habitações.

A infra-estrutura da edificação compõe-se dos seguintes elementos estruturais: tubulões, blocos, vigas baldrames, vigas alavancas.

A superestrutura é constituída por: pilares, paredes, vigas, lajes maciças, etc.

A armadura de todos os elementos estruturais compõe-se de barras e fios de aço CA-50 e CA-60 com emendas por traspasses quando necessárias. As barras foram todas armazenadas em canteiro, em local coberto, e não permaneciam por muito tempo na obra, pois eram compradas conforme a necessidade de empregá-las. 
Quanto ao item projeto pode-se verificar a existência dos seguintes elementos: arquitetônico e estrutural. Não foi apresentado durante a inspeção o Memorial Descritivo, o sistema hidráulico (água fria, quente, esgoto, incêndio), os sistemas de gás, elétrico, telefonia, alvenarias, revestimentos, vedações, ar condicionado, etc., tal que permitissem verificar a interferência de todas as partes na edificação.

Quanto à postura tomada em canteiro com relação à qualidade, pôde-se constatar que havia controle tecnológico do concreto. Porém, não era prática comum a anotação dos relatos ocorridos em obra, tampouco o controle dos materiais dos outros subsistemas.

Em relação ao aço, foram realizados alguns ensaios em laboratório para se comprovar sua qualidade. Porém inexistiu o controle das barras em campo no ato de sua utilização (amostragem por lotes, verificação de bitola, por exemplo).

Durante a execução não houve rotatividade de mão-de-obra. Houve apenas uma pequena variação no setor de carpintaria, pois além do trabalho dos carpinteiros da empresa houve serviços subempreitados pela construtora.

As fôrmas foram compostas por material compensado resinado, produzidas no próprio canteiro de obras. Havia apenas um jogo de fồrmas de modo que montava-se um pavimento, concretava-se e, verificada a resistência do concreto, compatível com a solicitação, procedia-se à desmoldagem dos elementos estruturais. Assim era, sucessivamente, para as vigas e finalmente para as lajes. $\mathrm{O}$ reaproveitamento foi de fator 11 (conforme relatos), ou seja, o mesmo jogo de fồmas foi utilizado em todos os pavimentos sendo substituídas apenas partes dos moldes que já não apresentavam condições de uso.

Após cada desforma, limpava-se as fôrmas e aplicava-se desmoldante para se garantir acabamento nos elementos estruturais além de preservá-las antes de serem montadas novamente no próximo pavimento.

Através de informações obtidas do mestre de obras e posteriormente verificadas na inspeção "in loco", não foram empregados espaçadores quer sejam pastilhas, "caranguejos" ou qualquer outro tipo de elemento auxiliar no posicionamento da armadura.

O concreto utilizado nos elementos estruturais foi todo fornecido por concreteira local. $\mathrm{O} \mathrm{f}_{\mathrm{c}}$ empregado foi de $18 \mathrm{MPa}$ para todos os elementos estruturais, só havendo distinção para os tubulões onde se empregou $f_{\alpha k}$ de $15 \mathrm{MPa}$. 
Antes do início de cada concretagem, as fôrmas recebiam limpeza final e a operação somente era liberada após a vistoria do engenheiro e do mestre, para então serem molhadas.

Para a realização do adensamento do concreto, foram utilizados vibradores com agulhas de $37 \mathrm{~mm}$ e $45 \mathrm{~mm}$ de diâmetro, variando-se as características da agulha conforme a peça a ser concretada.

Não havia rigor de horário para o começo de uma concretagem podendo ter início no começo ou no correr do dia. Caso não houvesse tempo suficiente para se concluir uma concretagem num mesmo dia, no seguinte retomava-se o trabalho por esse trecho, estabelecendo-se então uma junta sempre no mesmo lugar.

Após o início de pega do concreto, seguia-se o processo de cura, molhando as lajes no instante em que o concreto apresentasse um princípio de endurecimento e se prolongava por um periodo de três dias. Todavia, o processo de cura úmida só atingia as lajes, pois os pilares não eram molhados e as vigas recebiam um quinhão de molhagem proveniente apenas da rega das lajes.

A fase de desforma não cumpriu nenhum planejamento. A retirada das escoras das vigas e das lajes seguia apenas as instruções do mestre.

Segundo o engenheiro responsável, não ocorreu nenhuma anormalidade durante a execução como problemas estruturais, grandes mudanças de projeto ou substituições de bitolas de aço. São mostrados a seguir os resultados pela Tabela 25. 
TABELA 25 - Número de observações e porcentagens de incidências patológicas parciais para cada elemento estrutural e integral do edificio “ $J$ ”.

\begin{tabular}{|c|c|c|c|c|c|c|c|c|c|c|}
\hline \multirow{2}{*}{$\begin{array}{l}\text { Eemento Estrutural } \\
\text { Tipo de manife staçáo patológica observada }\end{array}$} & \multicolumn{2}{|c|}{ Laje } & \multicolumn{2}{|c|}{ Viga } & \multicolumn{2}{|c|}{ Pilar } & \multicolumn{2}{|c|}{ Parede } & \multicolumn{2}{|c|}{ Total } \\
\hline & $\$$ & $\%$ & $\$$ & $\%$ & $\$$ & $\%$ & $\$$ & $\%$ & $\#$ & $\% *$ \\
\hline desaprumo & 0 & - & 0 & - & 0 & - & 2 & 4,00 & 2 & 0,27 \\
\hline torçáo da forma & 0 & - & 34 & 11,72 & 13 & 6,50 & 5 & 10,00 & 52 & 7,12 \\
\hline junta de concretagem & 15 & 7,89 & 17 & 5,86 & 13 & 6,50 & 8 & 16,00 & 53 & 7,26 \\
\hline falta de limpeza das formas & 39 & 20,53 & 12 & 4,14 & 0 & - & 2 & 4,00 & 53 & 7,26 \\
\hline falta de estanqueidade das formas & 15 & 7,89 & 9 & 3,10 & 0 & - & 15 & 30,00 & 39 & 5,34 \\
\hline falta de limpeza nos elementos estruturais & 0 & - & 0 & - & 4 & 2,00 & 4 & 8,00 & 8 & 1,10 \\
\hline disgregacăo & 9 & 4,74 & 2 & 0,69 & 0 & - & 0 & - & 11 & 1,51 \\
\hline bicheiras & 1 & 0,53 & 10 & 3,45 & 3 & 1,50 & 25 & 50,00 & 39 & 5,34 \\
\hline se gregafáo do conereto & 14 & 7,37 & 157 & 54,14 & 127 & 63,50 & 64 & 128,00 & 362 & 49,59 \\
\hline falta de cobrimento de proteçäo das armaduras & 35 & 18,42 & 54 & 18,62 & 5 & 2,50 & 3 & 6,00 & 97 & 13,29 \\
\hline efeito parede & 13 & 6,84 & 0 & - & 1 & 0,50 & 0 & - & 14 & 1,92 \\
\hline falta de allnhamento horizontal ou vertical & 22 & 11,58 & 26 & 8,97 & 8 & 4,00 & 6 & 12,00 & 62 & 8,49 \\
\hline carbonatacáo na superficie de concreto & 82 & 43,16 & 16 & 5,52 & 40 & 20,00 & 8 & 16,00 & 146 & 20,00 \\
\hline manchas de corresso ou armadura corroida & 42 & 22,11 & 21 & 7,24 & 6 & 3,00 & 7 & 14,00 & 76 & 10,41 \\
\hline fissuras de retraçáo & 0 & - & 1 & 0,34 & 0 & - & 0 & - & 1 & 0,14 \\
\hline fissuras inc linadas & 61 & 32,11 & 2 & 0,69 & 0 & - & 0 & - & 63 & 8,63 \\
\hline fissuras em tubulaçao & 0 & - & 15 & 5,17 & 0 & - & 0 & - & 15 & 2,05 \\
\hline fissuras verticais & 0 & - & 23 & 7,93 & 0 & - & 2 & 4,00 & 25 & 3,42 \\
\hline deformaçăo das formas & 3 & 1.58 & 27 & 9,31 & 25 & 12,50 & 65 & 130,00 & 120 & 16,44 \\
\hline reparos nos el estrut devido segregacoes & 0 & - & 14 & 4,83 & 12 & 6,00 & 98 & 196,00 & 124 & 16,99 \\
\hline Fiviacao & 100 & 52,63 & 17 & 5,86 & 2 & 1,00 & 4 & 8,00 & 123 & 16,85 \\
\hline eflorescencias & 95 & 50,00 & 15 & 5,17 & 3 & 1,50 & 1 & 2,00 & 114 & 15,62 \\
\hline falta de vibraçao & 5 & 2,63 & 0 & - & 0 & - & 0 & - & 5 & 0,68 \\
\hline desagregaçáo do concreto & 0 & - & 1 & 0,34 & 0 & - & 0 & - & 1 & 0,14 \\
\hline
\end{tabular}

\subsection{2 - EDIFÍCIO RESIDENCIAL "L"}

A inspeção do presente edifício foi realizada em meados de maio/97.

No instante da visita constatou-se que a obra iniciada em dezembro de 1996 encontrava-se com o subsistema estrutura concluído e começava a execução do subsistema alvenaria.

O edificio residencial está inserido em ambiente urbano e constitui-se por três pavimentos sendo que cada pavimento-tipo corresponde a seis apartamentos, totalizando dezoito habitações

A infra-estrutura da edificação compõe-se dos seguintes elementos estruturais: estacas a trado rotativo, blocos e vigas baldrames.

A superestrutura é constituída por: pilares, vigas e lajes pré-moldadas protendidas.

A armadura de todos os elementos estruturais compõe-se de barras e fios de aço CA-50 e CA-60 com emendas por traspasses quando necessárias. As barras foram todas armazenadas em canteiro, em local coberto e não permaneciam por muito tempo na obra, pois eram compradas conforme a necessidade de empregá-las. 
Quanto ao item projeto pode-se verificar a existência dos seguintes elementos: arquitetônico, estrutural, sistema hidráulico e os sistemas elétrico e alvenarias. Não foi apresentado durante a inspeção o Memorial Descritivo, sistemas de gás, revestimentos, vedações, etc., tal que permitissem verificar a interferência de todas as partes na edificação.

Quanto à postura tomada em canteiro com relação à qualidade, pôde-se constatar que havia controle tecnológico do concreto. Porém, não era prática comum a anotação dos relatos ocorridos em obra, tampouco o controle dos materiais dos outros subsistemas.

Em relação ao aço, sempre que se mudava o fornecedor ou se o armador notasse diferença nas barras eram realizados alguns ensaios em laboratório para se comprovar sua qualidade. Porém não houve controle das barras em campo no ato de sua utilização (amostragem por lotes, verificação de bitola, por exemplo).

Durante a execução não houve rotatividade de mão-de-obra.

As fồmas foram compostas por compensado resinado e plastificado de $12 \mathrm{~mm}$, produzidas no próprio canteiro de obras. Havia apenas um jogo de fồrmas, de modo que montava-se um pavimento, concretava-se e, verificada a resistência do concreto, compatível com a solicitação, procedia-se à desmoldagem dos elementos estruturais, para nova aplicação no próximo pavimento. Assim era, sucessivamente, para as vigas, pilares e lajes.

O reaproveitamento das fôrmas foi de $80 \%$ conforme relatos do engenheiro responsável.

Através de informações obtidas do mesmo, verificou-se que não foram empregados espaçadores ou qualquer outro tipo de elemento auxiliar no posicionamento da armadura.

O concreto utilizado nos elementos estruturais foi todo fornecido por concreteira local. O $\mathrm{f}_{\mathrm{ck}}$ empregado foi de $20 \mathrm{MPa}$ brita 1 , abatimento $60 \pm 10 \mathrm{~mm}$, para todos os elementos estruturais só havendo distinção para as estacas onde se empregou $f_{d k}$ de $15 \mathrm{MPa}$, brita $1 \mathrm{e} 2$, abatimento $60 \pm 10 \mathrm{~mm}$.

Antes do início de cada concretagem, o engenheiro responsável verificava prumo, alinhamento, posicionamento de ferragem, estanqueidade e limpeza para só então liberar as fôrmas.

Para realização do adensamento do concreto, foram utilizados vibradores com agulhas de $37 \mathrm{~mm}$. 
Caso não houvesse tempo suficiente para se concluir uma concretagem num mesmo dia, no seguinte retomava-se o trabalho por esse trecho, estabelecendo-se então uma única junta.

A cura se iniciava logo em seguida à concretagem e prosseguia por três a quatro dias. Caso o tempo estivesse quente esse período se estendia para uma semana. Todavia, o processo de cura úmida só atingia as lajes e vigas pois os pilares não eram molhados, recebiam um quinhão de molhagem proveniente apenas da rega das lajes.

Quanto à desforma, ela se dava a sete dias de idade do concreto para os pilares, quatorze dias para as vigas e as lajes no mínimo com vinte e um dias da idade do concreto.

Para as vigas, a retirada das escoras se fazia do centro para as laterais, todas de uma só vez, e em seguida reescorava-as.

Para as lajes, retirava-se as escoras alternadamente pelas extremidades e nos centros dos vãos para poder reescorá-las.

Não ocorreu nenhuma anormalidade durante a execução. A única mudança ocorrida foi a troca de engenheiro responsável entre as fases de concretagem das estacas para a concretagem dos blocos para cima. São mostrados a seguir os resultados pela Tabela 26.

TABELA 26 - Número de observações e porcentagens de incidências patológicas parciais para cada elemento estrutural e integral do edificio " $L$ ".

\begin{tabular}{|c|c|c|c|c|c|c|c|c|}
\hline \multirow{2}{*}{$\begin{array}{l}\text { Eemento Estrutural } \\
\text { Tipo de manifestação patológica observada }\end{array}$} & \multicolumn{2}{|c|}{ Laje } & \multicolumn{2}{|c|}{ Viga } & \multicolumn{2}{|c|}{ Pilar } & \multicolumn{2}{|c|}{ Total } \\
\hline & $\$$ & $\%$ & $\$$ & $\%$ & $\$$ & $\%$ & $\#$ & $\boldsymbol{\%}^{*}$ \\
\hline desaprumo & 0 & - & 0 & - & 0 & - & 0 & - \\
\hline torçāo da fórma & 0 & - & 0 & 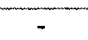 & 0 & - & 0 & - \\
\hline junta de concretagem & 0 & $=$ & 0 & $=$ & 0 & - & 0 & - \\
\hline falta de limpeza das formas & 0 & - & 0 & - & 0 & - & 0 & - \\
\hline falta de estanqueidade das fórmas & 26 & 43,33 & 53 & 36,81 & 0 & - & 79 & 25,32 \\
\hline falta de limpeza elementos estruturais & 0 & - & 27 & 18,75 & 0 & - & 27 & 8,65 \\
\hline disgregação & 0 & - & 0 & - & 0 & - & 0 & - \\
\hline bicheiras & 0 & - & 10 & 6,94 & 8 & 7,41 & 18 & 5,77 \\
\hline segregaçāo do concreto & 0 & - & 70 & 48,61 & 44 & 40,74 & 114 & 36,54 \\
\hline falta de cobrimento de proteçao das armaduras & 0 & - & 64 & 44,44 & 0 & - & 64 & 20,51 \\
\hline efeito parede & 0 & - & 0 & - & 0 & - & 0 & - \\
\hline falta de alinhamento horizontal ou vertical & 0 & - & 19 & 13,19 & 30 & 27,78 & 49 & 15,71 \\
\hline carbonatação na superfície de concreto & 0 & - & 0 & - & 0 & - & 0 & - \\
\hline manchas de corrosäo ou armadura corróda & 0 & - & 0 & - & 0 & - & 0 & 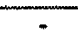 \\
\hline fissuras de retração & 0 & - & 0 & - & 6 & 5,56 & 6 & 1,92 \\
\hline fissuras inclinadas & 0 & - & 0 & - & 0 & - & 0 & - \\
\hline fissuras em tubulação & 0 & - & 0 & - & 0 & - & 0 & - \\
\hline fissuras verticais & 0 & - & 0 & - & 0 & - & 0 & - \\
\hline deformação das fórmas & 0 & - & 11 & 7,64 & 10 & 9,26 & 21 & 6,73 \\
\hline reparos nos el. estrut. devido segregaçōes & 0 & - & 0 & - & 0 & - & 0 & - \\
\hline lixiviação & 0 & - & 0 & - & 0 & - & 0 & - \\
\hline eflorescências & 0 & - & 0 & - & 0 & - & 0 & - \\
\hline falta de vibração & 0 & - & 0 & - & 0 & - & 0 & $=$ \\
\hline desagregação do concreto & 0 & - & 0 & - & 0 & - & 0 & - \\
\hline mal posicionamento da armadura & 0 & - & 0 & - & 0 & - & 0 & - \\
\hline
\end{tabular}




\section{DISCUSSÃO}

Após a compilação dos dados teve-se a oportunidade de observar-se que apesar da maior parte dos edificios estudados utilizarem sistemas construtivos simples e correntes, foram detectadas, em grande número, manifestações patológicas originadas na maioria das vezes por vícios cometidos na fase de execução advindos de erros primários decorrentes de má ou inexistente representação em projeto dos objetos a serem construídos.

Para iniciar uma discussão sobre os resultados obtidos é válido observar as estatísticas que dão margem às primeiras conclusões, conforme Figura 37.

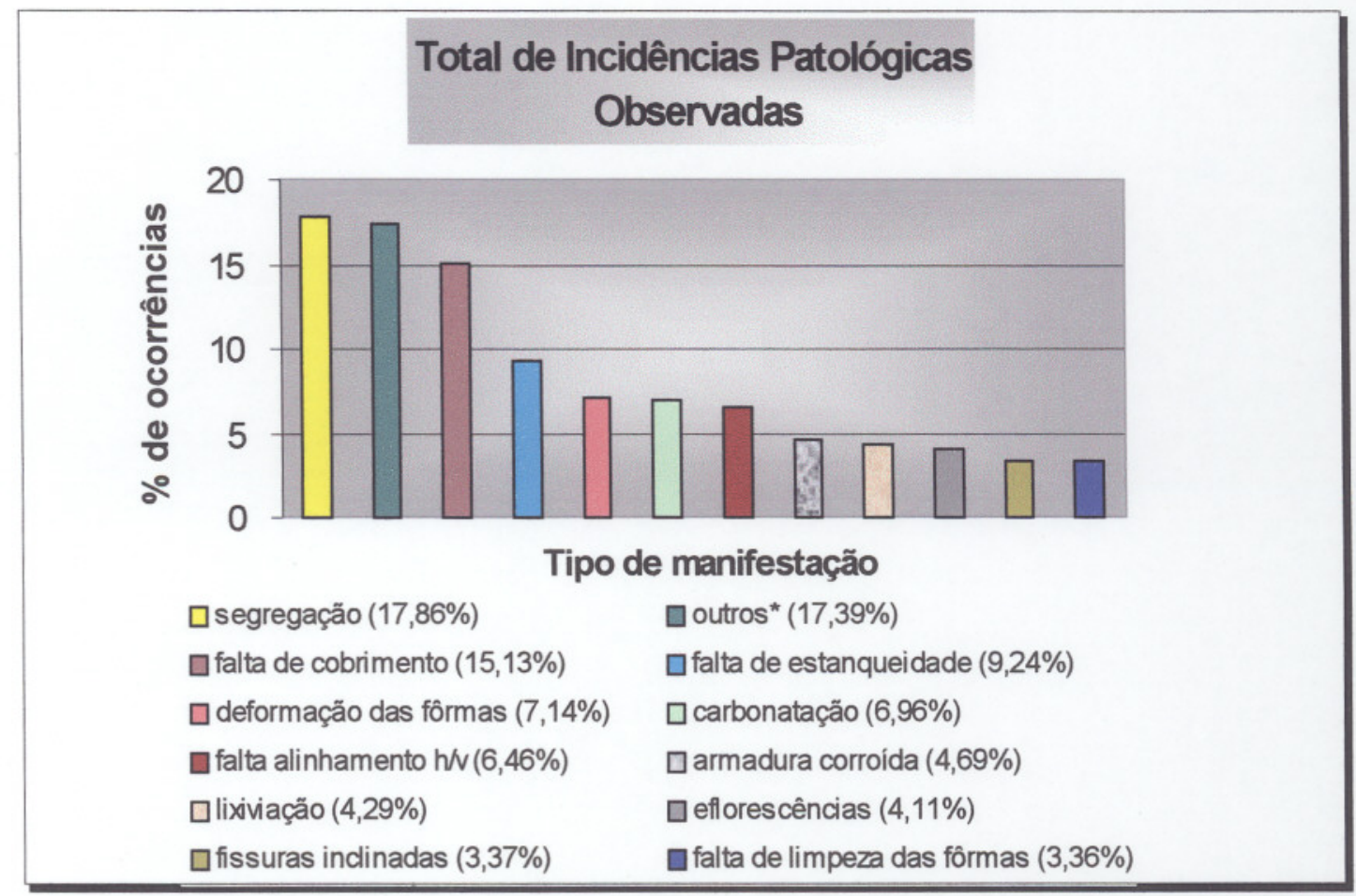

FIGURA 37 - Classificação dos tipos de incidências observados em relação ao número de ocorrências. 
Quando se analisa qual a ocorrência mais comum, nos edificios visitados, a segregação do concreto lidera os números, seguida pela falta da camada de cobrimento de proteção das armaduras e falta de estanqueidade das fồrmas.

Esses números, se não assustam, causam certa incompreensão pela sua ocorrência pois desde que a tecnologia do concreto é conhecida, o planejamento da concretagem e o adensamento do concreto seguem em conjunto desenvolvimento do material.

A falta da camada de cobrimento de proteção das armaduras é outro agravante nas peças de concreto quanto à possibilidade de torná-las mais vulneráveis às ações deletérias.

Porém, apesar de todos os estudos sobre o assunto darem conta desse fato, raramente se encontram projetos estruturais que destaquem informações específicas sobre as camadas de cobrimento, por exemplo.

Se isso já é dificil de ser encontrado nos projetos, quase impossível é encontrar diferenciações dessas camadas de cobrimento para os outros elementos estruturais.

Ao começar a abrir mais esse leque de resultados, deve-se observar o que acontece com os elementos estruturais. Ao observar os dados da Figura 37 não se deve generalizálos, considerando que os diferentes elementos estruturais não apresentam mesmo grau de dificuldade ao serem executados.

Tanto isso não é verdade que ao se analisar os dados gerais, ou seja, a compilação dos dados de todos os edificios visitados, começa a existir diferenciação dos resultados para cada elemento estrutural conforme Tabela 27. 
TABELA 27 - Total das ocorrências por elemento estrutural.

\begin{tabular}{|c|c|c|c|c|}
\hline $\begin{array}{l}\text { Elemento } \\
\text { Estrutural }\end{array}$ & $\begin{array}{c}\text { lajes } \\
\text { tot }=1703\end{array}$ & $\begin{array}{c}\text { vigas } \\
\text { tot. }=\mathbf{4 3 1 9}\end{array}$ & $\begin{array}{c}\text { pilares } \\
\text { tot: }=2062\end{array}$ & $\begin{array}{l}\text { paredes } \\
\text { tot. }=1026\end{array}$ \\
\hline \% de manifestacőes patológlcas observadas & $\%$ & $\%$ & $\%$ & $\%$ \\
\hline desaprumo & - & 0,02 & 1,70 & 0,68 \\
\hline torção da fôrma & - & 2,57 & 1,65 & 1,56 \\
\hline junta de concretagem & 2,35 & 2,04 & 0,97 & 1,95 \\
\hline falta de limpeza das fômmas & 11,22 & 5,53 & 1,45 & 3,51 \\
\hline falta de estanqueidade & 34,53 & 16,09 & 0,82 & 6,04 \\
\hline falta de limpeza nos elementos estruturais & 8,16 & 3,96 & 3,78 & 4,19 \\
\hline disgregação & 1,82 & 3,61 & 1,31 & 0,19 \\
\hline bicheiras & 1,82 & 2,34 & 5,29 & 9,06 \\
\hline segregaçào do concreto & 12,39 & 22.27 & 46,90 & 48,15 \\
\hline falta da camada de cobrimento de proteçao das armaduras & 20,14 & 39,94 & 5,77 & 4,29 \\
\hline efeito parede & 19,61 & - & 0,15 & - \\
\hline falta alinhamento horizontal ou vertical & 16,21 & 10,53 & 6,98 & 7,50 \\
\hline carbonatação na camada de cobrimento & 25,72 & 3,43 & 20,95 & 0,78 \\
\hline manchas de corrosão ou armadura corroida & 10,45 & 9,03 & 4,22 & 3,61 \\
\hline fissuras de retração & - & 0,86 & 2,09 & - \\
\hline fissuras inclinadas & 28,24 & 0,37 & - & - \\
\hline fissuras em tubulação & - & 4,45 & - & - \\
\hline fissuras verticais & - & 2,89 & - & 0,19 \\
\hline deformação das fômas & 3,99 & 12,13 & 12,56 & 19,69 \\
\hline reparo nos el. estrut devido segregaçöes & 2,11 & 1,16 & 4,32 & 17,06 \\
\hline lixiviaçāo & 33,47 & 1,20 & 0,29 & 0,39 \\
\hline eflorescências & 32,35 & 1,11 & 0,29 & 0,10 \\
\hline falta de vibração & 4,46 & 0,07 & - & - \\
\hline desagregação do concreto & - & 0,23 & - & - \\
\hline armadura mal posicionada & 0,53 & 0,44 & 0,39 & $=$ \\
\hline
\end{tabular}

\section{1 - LAJE}

Num total de 1703 lajes observadas, 34,53\% delas apresentaram problemas de falta de estanqueidade da fồrmas, $33,47 \%$ de lixiviação e $32,35 \%$ de eflorescências decorrentes de carbonatação como apresentado na Tabela 28.

A presença de fissuras inclinadas foi constatada em $28,24 \%$ dos elementos estruturais.

Ao esmiuçar esses valores, observou-se que os edificios G $(75,56 \%), \mathrm{D}(67,31 \%)$, I $(61,11 \%), L(43,33), E(42,86 \%)$ e B $(41,56 \%)$, causaram grande influência na compilação final devido alguns fatores que puderam ser observados através dos checklists de cada edificação.

A falta de estanqueidade das fôrmas pode se originar por dois fatores: falta de vedação das mesmas antes das concretagens e reaproveitamento inadequado das fôrmas durante uma construção. 
Ao se analisar todos os checklists dos edificios mencionados anteriormente comprovou-se que as fôrmas tiveram um aproveitamento de $100 \%$, com exceção do edificio $\mathrm{L}$

O mais curioso é que para todos esses edifícios, bem como nos outro onde a questão da estanqueidade foi irrelevante em função das outras manifestações, os relatos fornecidos pelos entrevistados foram incisivos quanto à questão da verificação das fôrmas após sua montagem e colocação das armaduras, verificação de nível, prumo e estanqueidade.

No checklist do edificio $\mathrm{L}$ inclusive, o engenheiro foi o único a listar todos os itens acima mencionados como básicos na verificação das fồrmas para uma prévia liberação da concretagem.

Como na fase das visitas, os elementos estruturais encontravam-se concretados, fica dificil saber qual é a real postura tomada nesses edificios quanto à estanqueidade.

Assim torna-se difícil saber como estas fôrmas são vedadas. Talvez, se por critérios próprios de cada construtora não se vede as fồrmas ou, por último, se a vedação usada está imprópria ou insuficiente.

Porém, deve-se levantar a hipótese de que mesmo com as fồrmas devidamente vedadas pode ocorrer a fuga de pasta entre vãos de painéis, devido a possíveis movimentações das escoras como já foi referido por RIPPER (1996) no Capítulo 3 ou por movimentações nas próprias fôrmas caso estas já estiverem com um alto fator de aproveitamento.

Isso se deve à perda das características de resistência dos painéis de madeira compensada expostos às grandes solicitações no ato da concretagem, e também pelo grande número de ciclos de montagem e desmontagem para serem reaproveitados.

Associado à questão do reaproveitamento das fồmas, um mal escoramento ou mal encunhamento das escoras também permitem movimentações da fồrmas (RIPPER, 1996). Se estas já estão muito velhas, os pontos mais vulneráveis serão exatamente as bordas do painel.

Aparentemente, em todos os edifícios que engrossam as estatísticas, segundo relatos, foram tomados os cuidados básicos com as fồrmas como o uso de desmoldante entre uma montagem e outra das peças. 
A mão-de-obra empregada na confecção e montagem das fồrmas para todos esses casos era da própria construtora, com exceção do edificio $B$, que também subempreitou carpinteiros em algumas fases da obra.

Sendo assim, fica descartada a hipótese de montagens ou outro tipo de problema oriundo de rotatividade de mão-de-obra.

Do mesmo modo que não houve rotatividade de funcionários, verificou-se através dos checklists que não houve nesses edificios nenhuma mudança repentina ou imprevisível nos projetos ou na execução.

Quanto aos altos índices apresentados de lixiviação e eflorescências decorrentes de carbonatação, podemos unir o item fissuras inclinadas para estabelecermos uma análise global dos fatos que são realmente interligados entre si.

Os edificios que apresentam esses itens em porcentagens consideráveis são os prédios $\mathrm{G}, \mathrm{H}$, I e J.

$\mathrm{O}$ edificio $\mathrm{G}$ é o que apresenta maiores incidências nesses três itens, seguido então pelos edifícios I e J para lixiviação e eflorescências, e por último o edificio $H$.

Curiosamente os edificios G, I e H são da mesma construtora. Outro fato relevante sobre essas construções é que a quantidade de informações, bem como projetos e controles apresentados nos checklists foram os mais completos comparativamente aos outros edificios visitados, existindo inclusive um programa de qualidade próprio elaborado pela construtora.

$\mathrm{O}$ fator que leva às incidências citadas relaciona-se basicamente à cura dos elementos estruturais.

Como se pôde ver, os valores de lixiviação e eflorescências por carbonatação e fissuras sobressaíram às demais incidências observadas nas lajes, o problema pode estar relacionado com a cura, deficiência de adensamento ou até mesmo às juntas de concretagem.

Todos os checklists relatam que existiu a chamada "cura" em todos os edificios estudados.

Segundo os relatos do edifício G, a cura começou após as concretagens, estendendo-se por um período de sete dias, molhando-se todos os elementos estruturais durante todo o dia. 
No edificio $\mathrm{H}$, a cura começou quatro horas após a concretagem, molhando-se todos elementos estruturais em questão numa freqüência de três vezes ao dia.

Nas anotações de edificio I, a cura começou seis horas depois da concretagem com duração de sete dias, levando-se em conta todas as peças concretadas. Porém não se mencionou a freqüência de molhagem.

Finalmente no caso do edificio J observa-se que o processo de cura começou logo que o concreto apresentava endurecimento, molhando-se as lajes por um período de três dias.

Contudo, como não se teve acesso ao diário de obras de nenhum dos edifícios visitados, tornou-se dificil averiguar informações sobre as condições climáticas dos dias de concretagem.

No caso dos edificios G, H e I poderia-se levantar a hipótese de alguns dos problemas observados estarem ligados cronologicamente aos problemas financeiros da construtora, o que desencadeou o descontentamento dos funcionários.

Em todos os casos possivelmente a cura estendeu-se apenas às lajes.

Sendo assim, é válido observar o desempenho dessas obras no decorrer de suas construções (ANEXOS).

Para o edificio $\mathrm{G}$ as lajes compreendidas entre o quarto e o oitavo pavimentos, apresentaram aumento das fissuras, eflorescências e lixiviação. Antes já haviam sido detectadas tais ocorrências no segundo pavimento, porém em quantidades desprezíveis.

No edificio $\mathrm{H}$, as incidências citadas acima são observadas ao longo de todos pavimentos.

No edificio I, as ocorrências aparecem também no decorrer dos pavimentos. Porém nesse caso observa-se realmente uma progressão das incidências a partir do quinto pavimento, sendo identificadas até o décimo-primeiro pavimento.

No edificio J, de construtora diferente, nota-se acentuação dos problemas do sexto ao oitavo pavimentos.

A hipótese de associação dos problemas da construção estarem ligados às dificuldades financeiras da construtora só poderia ser aplicada ao edificio I. Porém, para tal conclusão, deve-se considerar o edificio de forma global considerando todas as incidências observadas ao longo de todos elementos estruturais de cada pavimento. 
Alguns fatores externos devem ser ressaltados como relevantes na interferência do processo de cura

Um desses fatores foi levantado em conversas informais com o engenheiro responsável pelo edifício $\mathrm{G}$, que relatou a insuficiência de água devido a um baixo abastecimento no canteiro que se prolongou até a concretagem da quinta laje.

Tal fato danificou o processo da cura dos elementos estruturais até o pavimento mencionado. A partir daí, o abastecimento normalizou-se possibilitando a realização do processo de cura para os demais pavimentos

Problemas como deficiência no adensamento e juntas frias de concretagem também podem causar caminhos de percolação de gases no concreto, pela existência de canalículos.

No caso de mal adensamento do concreto, aumenta-se a porosidade e a permeabilidade.

Quanto às juntas de concretagem, pode ser uma das causas redundantes, pois analisando os checklists dos edificios observados, podem ser notadas algumas dessas juntas ao longo das lajes estudadas.

Para o edificio $G$, aparentemente não há correspondência das juntas com as fissuras inclinadas pois só houve uma ocorrência de junta.

Porém no edificio $\mathrm{H}$ foram observadas juntas de concretagem nos mesmos pavimentos que apresentam fissuras, lixiviações e eflorescências com exceção do segundo.

No edificio I foram anotadas juntas em dois dos dezoito pavimentos que apresentaram as demais incidências.

No entanto, no edifício $\mathrm{J}$, todos os pavimentos que apresentaram fissuras, lixiviações e eflorescências por carbonatação apresentaram também de uma a três ocorrências de juntas de concretagem a cada pavimento estudado. Segundo informações coletadas nesse checklist, não havia rigor nos horários de concretagem, acarretando juntas ao longo de uma laje de forma aleatória em todos os pavimentos. 
TABELA 28 - Resumo das incidências observadas no elemento estrutural - laje em todo edifícios (continua)

\begin{tabular}{|c|c|c|c|c|c|c|c|c|c|c|c|c|}
\hline EDIFICIO & Edifici & $a l=90$ & Edifici & $a=154)$ & Edifici & $=360$ & Edificic & $1=156$ & Edifici & al $=35$ ) & Edific & $a=76$ \\
\hline Tipo de manifestação patológica observada & $\mathbf{s}$ & $\%$ & $\mathbf{s}$ & $\%$ & $\mathbf{s}$ & $\%$ & $\mathbf{s}$ & $\%$ & 5 & $\%$ & $\$$ & $\%$ \\
\hline desaprumo & 0 & - & 0 & $\cdot$ & 0 & 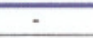 & 0 & - & $\overline{0}$ & - & 0 & - \\
\hline torçăo da fôrma & 0 & $\cdot$ & 0 & $\cdot$ & 0 & - & 0 & - & 0 & - & 0 & - \\
\hline junta de concretagem & 0 & - & 2 & 1,30 & 0 & - & 8 & 5,13 & 0 & - & 0 & - \\
\hline falta de limpeza das formas & 34 & 37,78 & 51 & 33,12 & 23 & 6,39 & 12 & 7,69 & 3 & 8,57 & 10 & 13,16 \\
\hline falta de estanqueidade & 16 & 17,78 & 64 & 41,56 & 79 & 21,94 & 105 & 67,31 & 15 & 42,86 & 0 & $\cdot$ \\
\hline falta de limpeza nos elementos estruturais & 0 & $\cdot$ & 18 & 11,69 & 0 & $\cdot$ & 58 & 37,18 & 0 & - & 1 & 1,32 \\
\hline disgregaçằo & 0 & $\cdot$ & 0 & - & 2 & 0,56 & 1 & 0,64 & 0 & - & 5 & 6,58 \\
\hline bicheiras & 16 & 17,78 & 1 & 0,65 & 1 & 0,28 & 4 & 2,56 & 0 & - & 0 & - \\
\hline segregaçáo do concreto & 9 & 10,00 & 8 & 5,19 & 0 & - & 47 & 30,13 & 12 & 34,29 & 5 & 6,58 \\
\hline falta de cobrimento de proteçăo das armaduras & 21 & 23,33 & 12 & 7,79 & 75 & 20,83 & 64 & 41,03 & 16 & 45,71 & 22 & 28,95 \\
\hline efeito parede & 21 & 23,33 & 81 & 52,60 & 89 & 24,72 & 41 & 26.28 & 12 & 34,29 & 2 & 2,63 \\
\hline falta de alinhamento horizontal ou vertical & 1 & 1,11 & 29 & 18,83 & 6 & 1,67 & 52 & 33,33 & 3 & 8,57 & 42 & 55,26 \\
\hline carbonataçăo na superficie do concreto & 1 & 1,11 & 0 & - & 0 & - & 0 & - & 0 & $\cdot$ & 56 & 73,68 \\
\hline manchas de corrosăo ou armadura corrolda & 7 & 7,78 & 6 & 3,90 & 7 & 1,94 & 45 & 28,85 & 0 & $\cdot$ & 7 & 9,21 \\
\hline fissuras de retração & 0 & - & 0 & $\cdot$ & 0 & $\cdot$ & 0 & - & 0 & $\cdot$ & 0 & - \\
\hline fissuras inclinadas & 2 & 2,22 & 29 & 18,83 & 53 & 14,72 & 55 & 35,26 & 0 & - & 11 & 14,47 \\
\hline fissuras em tubulaçăo & 0 & $\cdot$ & 0 & - & 0 & - & 0 & - & 0 & $\cdot$ & 0 & - \\
\hline fissuras verticais & 0 & - & 0 & - & 0 & - & 0 & - & 0 & - & 0 & $\cdot$ \\
\hline deformaçăo das fôrmas & 4 & 4,44 & 5 & 3,25 & 0 & - & 6 & 3,85 & 10 & 28,57 & 0 & - \\
\hline reparo nos el. estrut. devido segregaçőes & 0 & $\cdot$ & 0 & $\cdot$ & 0 & $\cdot$ & 2 & 1,28 & 0 & - & 5 & 6,58 \\
\hline lixiviaçăo & 2 & 2,22 & 29 & 18,83 & 62 & 17,22 & 75 & 48,08 & 0 & $\cdot$ & 3 & 3,95 \\
\hline eflorescências & 2 & 2,22 & 29 & 18,83 & 58 & 16,11 & 75 & 48,08 & 0 & $\cdot$ & 5 & 6,58 \\
\hline falta de vibraçăo & 0 & - & 7 & 4,55 & 12 & 3,33 & 17 & 10,90 & 14 & 40,00 & 3 & 3,95 \\
\hline desagregaçăo do concreto & 0 & $\cdot$ & 0 & - & 0 & - & 0 & - & 0 & $\cdot$ & 0 & - \\
\hline armadura mal posicionada & & - & & - & & - & & - & & - & & - \\
\hline
\end{tabular}

\$ - total de ocorrências observadas no edifício

$\%$ - porcentagem da incidência no edifício 
TABELA 28 - Resumo das incidências observadas no elemento estrutural - laje em todos edifícios (continuação)

\begin{tabular}{|c|c|c|c|c|c|c|c|c|c|c|c|c|}
\hline EDIFICIO & Edifici & $\mathrm{tal}=45)$ & Edificic & $\mathrm{al}=357)$ & Edifici & $=180$ & Edifici & $T=190$ & Edifíc & $\mathrm{al}=60$ & Total & $=1703$ \\
\hline Tipo de manifestação patológica observada & s & $\%$ & $\$$ & $\%$ & $\$$ & $\%$ & $\mathbf{s}$ & $\%$ & $\$$ & $\%$ & $\mathbf{s}$ & $\%$ \\
\hline desaprumo & 0 & 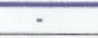 & 0 & - & 0 & $=$ & 0 & - & 0 & - & 0 & - \\
\hline torçăo da fôrma & 0 & - & 0 & - & 0 & - & 0 & - & 0 & - & 0 & - \\
\hline junta de concretagem & 1 & 2,22 & 11 & 3,08 & 3 & 1,67 & 15 & 7,89 & 0 & - & 40 & 2,35 \\
\hline falta de limpeza das formas & 0 & - & 17 & 4,76 & 2 & 1,11 & 39 & 20,53 & 0 & - & 191 & 11,22 \\
\hline falta de estanqueidade & 34 & 75,56 & 124 & 34,73 & 110 & 61,11 & 15 & 7,89 & 26 & 43,33 & 588 & 34,53 \\
\hline falta de limpeza nos elementos estruturais & 3 & 6,67 & 32 & 8,96 & 27 & 15,00 & 0 & - & 0 & $\cdot$ & 139 & 8,16 \\
\hline disgregaçăo & 10 & 22,22 & 0 & - & 4 & 2,22 & 9 & 4,74 & 0 & - & 31 & 1,82 \\
\hline bicheiras & 6 & 13,33 & 0 & - & 2 & 1,11 & 1 & 0,53 & 0 & - & 31 & 1,82 \\
\hline segregaçăo do concreto & 82 & 182,22 & 20 & 5,60 & 14 & 7,78 & 14 & 7,37 & 0 & - & 211 & 12,39 \\
\hline falta de cobrimento de proteção das armaduras & 17 & 37,78 & 75 & 21,01 & 6 & 3,33 & 35 & 18,42 & 0 & - & 343 & 20,14 \\
\hline efeito parede & 3 & 6,67 & 71 & 19,89 & 1 & 0,56 & 13 & 6,84 & 0 & $\cdot$ & 334 & 19,61 \\
\hline falta de alinhamento horizontal ou vertical & 24 & 53,33 & 72 & 20,17 & 25 & 13,89 & 22 & 11,58 & 0 & - & 276 & 16,21 \\
\hline carbonataçăo na superficie do concreto & 49 & 108,89 & 130 & 36,41 & 120 & 66,67 & 82 & 43,16 & 0 & - & 438 & 25,72 \\
\hline manchas de corrosắo ou armadura corroída & 37 & 82,22 & 16 & 4,48 & 11 & 6,11 & 42 & 22,11 & 0 & - & 178 & 10,45 \\
\hline fissuras de retraçăo & 0 & - & 0 & - & 0 & $\cdot$ & 0 & - & 0 & - & 0 & - \\
\hline fissuras inclinadas & 38 & 84,44 & 125 & 35,01 & 107 & 59,44 & 61 & 32,11 & 0 & - & 481 & 28,24 \\
\hline fissuras em tubulaçăo & 0 & - & 0 & - & 0 & - & 0 & - & 0 & $\cdot$ & 0 & - \\
\hline fissuras verticais & 0 & - & 0 & $\cdot$ & 0 & - & 0 & - & 0 & - & 0 & - \\
\hline deformaçấo das formas & 1 & 2,22 & 30 & 8,40 & 9 & 5,00 & 3 & 1,58 & 0 & - & 68 & 3.99 \\
\hline reparo nos el. estrut. devido segregaçŏes & 17 & 37,78 & 3 & 0,84 & 9 & 5,00 & 0 & - & 0 & - & 36 & 2,11 \\
\hline Iixiviaçăı & 49 & 108,89 & 130 & 36,41 & 120 & 66,67 & 100 & 52,63 & 0 & - & 570 & 33,47 \\
\hline eflorescências & 49 & 108,89 & 122 & 34,17 & 116 & 64,44 & 95 & 50,00 & 0 & - & 551 & 32,35 \\
\hline falta de vibraçăo & 0 & - & 18 & 5,04 & 0 & - & 5 & 2,63 & 0 & - & 76 & 4,46 \\
\hline desagregaçăo do concreto & 0 & - & 0 & - & 0 & - & 0 & - & 0 & - & 0 & - \\
\hline armadura mal posicionada & 9 & 20,00 & & - & 0 & - & & - & & - & 9 & 0,53 \\
\hline
\end{tabular}

\$ - total de ocorrências observadas no edifício

$\%$ - porcentagem da incidência no edifício 


\section{2 - VIGA}

Foram computadas 4319 vigas no decorrer das investigações.

Ao se comparar a Figura 37 com a Tabela 27 que apresenta as ocorrências por elemento estrutural, nota-se que as vigas tiveram papel representativo nos números finais compilados.

Recorrendo à Tabela 27 pode-se quantificar as manifestações e obter as primeiras afirmações.

É preocupante observar que praticamente $40 \%$ das 4319 vigas analisadas apresentaram problemas como falta da camada de cobrimento de proteção das armaduras. Seguindo essa avaliação, $22,27 \%$ das vigas apresentaram segregações no concreto, $16,09 \%$ delas apresentaram fuga da pasta por falta de estanqueidade das fồmas e 12,13\% dos elementos estruturais apresentaram suas superficies disformes pelas deformações das fồrmas.

Os casos acima observados nesse instante da construção permitem que o concreto torne-se susceptível ao ataque de agentes deletérios podendo desencadear futuras patologias advindas dessas manifestações.

Muitas vezes, dependendo das condições ambientais ou da exposição dos elementos estruturais, essas manifestações são desencadeadas num curto período de tempo em decorrência do $\mathrm{CO}_{2}$ presente na atmosfera.

$\mathrm{O}$ concreto de peças estruturais armadas com pequenas camadas de cobrimento das armaduras resultam em rápida despassivação das mesmas, devido à penetração do $\mathrm{CO}_{2}$ por difusão através dos poros contíguos na superficie do concreto, desencadeando portanto um processo de corrosão das armaduras.

Para agravar a situação, existiam algumas vigas que praticamente não apresentavam proteção das armaduras estando estas em contato direto com o ar e conseqüente $\mathrm{CO}_{2}$ da atmosfera.

Nesse caso, o processo de corrosão já é desencadeado sem a necessidade de passar pelo estágio de despassivação das suas armaduras pois nesses pontos são criados naturalmente diferenciais de potenciais caracterizando uma pilha eletroquímica. 
A segregação do concreto também representa um mecanismo de ocorrência gerador de possíveis manifestações patológicas degradadoras das estruturas de concreto.

Bem como nas peças com falta da camada de cobrimento de proteção das armaduras, as estruturas de concreto que apresentem segregações tenderão às mesmas conseqüências de despassivação das armaduras e posterior desencadeamento de corrosão.

A falta da camada de cobrimento de proteção das armaduras e a segregação do concreto são problemas que apesar de constantes, são facilmente evitáveis. No primeiro caso, com uso de espaçadores entre ferragens e fôrmas, referenciando-os em projeto, e especificações e detalhamento das espessuras das camadas de cobrimento adequadas para cada elemento estrutural nos projetos estruturais.

No segundo caso, cuidados como compatibilização do tamanho da agulha do vibrador com os espaçamentos entre as armaduras, limpeza das fồrmas, taxas de armaduras compatíveis com as dimensões dos elementos estruturais, especificação do concreto quanto a granulometria das britas, coerente com os espaçamentos entre armaduras e, finalmente, a garantia de um bom e correto adensamento são medidas que eliminam possíveis formações de regiões segregadas.

A falta de estanqueidade das fồrmas pode estar relacionada com a deformação destas em função da alta taxa de reaproveitamento.

Entretanto, a falta de estanqueidade das formas pode ser fruto de falta de vistoria pré-concretagem, não estando estas devidamente estanques ou simplesmente inexistindo vedação entre possíveis regiões de fuga de pasta de cimento.

Como já foi relatado no caso das lajes, a deformação das fôrmas origina-se pelos seguintes fatores: falta ou travamento indevido dos painéis laterais e escoramento ineficiente dos painéis de fundo, efeito da molhagem/secagem além da alta utilização das fồrmas. Devido esses fatores, as fồrmas sofrem deformações pelas altas pressões exercidas pelo concreto no ato do seu lançamento.

Ao verificar os dados compilados nos checklists dos edificios observou-se que todos os edificios visitados apresentaram altas porcentagens das ocorrências acima listadas. 
A falta de cobrimento, em vigas, afetou cerca de $40 \%$ desses elementos estruturais. Entretanto, no caso do edifício A esse valor foi de $69,39 \%$, e no edificio $\mathrm{H}$ foi $60,63 \%$.

$\mathrm{O}$ edificio $\mathrm{A}$ também lidera as estatísticas, no caso da segregação de vigas, com $56,46 \%$ e finalmente, o edificio $\mathrm{E}$ ganha no item de falta de estanqueidade das fồmas com $38,10 \%$ das ocorrências.

Analisando os quatro primeiros edificios que apresentaram os maiores índices de ocorrências acima mencionadas (A, E, H e L) conclui-se que a segregação e a falta da camada de cobrimento de proteção das armaduras no edificio A é um problema crônico que surge já no térreo com valores consideráveis, e se mantém com altos índices durante sua construção.

No edificio A houve um fato que chamou a atenção nas visitas, que foi a problemática da segregação do concreto (lajes).

O método construtivo adotado nesse caso foi de lajes nervuradas com enchimento entre nervuras com EPS (Espuma de Poliestireno Expandido).

Tal procedimento acumulou alguns problemas quanto ao manuseio com esse material, até então inédito nas obras visitadas na região, pois pela mão-de-obra não estar familiarizada com esse método construtivo implantado pela construtora, ao se montar as lajes houve necessariamente alguns cortes nas placas de EPS, tanto para encaixá-las nas nervuras quanto para a passagem dos embutidos.

Esse fato gerou um grande número de observações quanto à falta de limpeza das fồrmas, item irrelevante até então nos casos já elucidados.

No momento da vistoria das vigas pôde-se notar claramente regiões segregadas, principalmente nos fundos das vigas, que apesar de terem sido adensadas, o concreto não preencheu todo espaço das fôrmas pelo acúmulo dos flocos de EPS nas nervuras das lajes e nas próprias vigas como pode-se observar na Figura 38. 


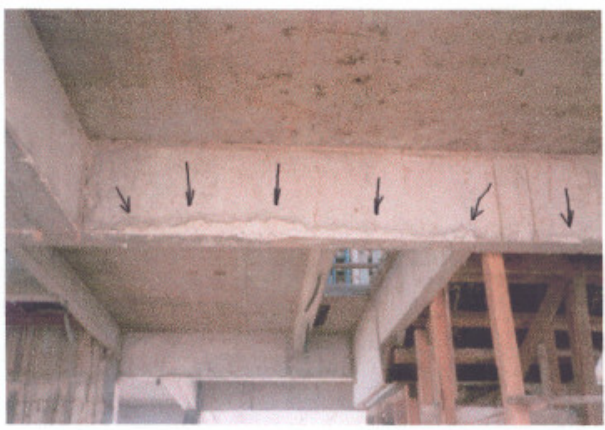

Figura 38 - Sujeira

proveniente de flocos de

EPS impedindo passagem do concreto (segregação).

Para os edificios E, H e L bem como os demais edificios visitados, seus respectivos projetos estruturais analisados mostram a espessura da camada de cobrimento $\operatorname{com} 1,50 \mathrm{~cm}$.

Esse cobrimento só foi confirmada através das seções transversais das vigas em projeto sendo que apenas um projeto discriminou essa informação nas próprias folhas de especificações.

Todas as vigas, sem exceção, apresentaram cobrimento de $1,50 \mathrm{~cm}$, independente das diferentes resistências de concreto adotadas para cada edifício.

Para esses mesmos edificios E, H e $\mathrm{L}$ as observações demonstram um comportamento aceitável. Devido ao reaproveitamento das fồrmas, eles seguiram a tendência das ocorrências aumentarem conforme o andamento da construção.

Entretanto, como já mencionado anteriormente, a falta da camada de cobrimento de proteção das armaduras é um problema que não se restringe aos edifícios acima. É um problema generalizado.

Ao consultar os checklists, os dados despertam no mínimo curiosidade, pois relatou-se que das onze obras visitadas seis edificios adotam o emprego de pastilhas espaçadoras das armaduras (C, D, E, G, H e I) contra cinco que declaradamente não utilizam espaçadores nas vigas (A, B, F, J e L).

Assim, os resultados dos edificios A, F e L parecem ser os mais coerentes. Em contrapartida, as informações sobre os edificios como o D, E, G, H e I são enigmáticas a partir do momento que declaram usar espaçadores nos elementos estruturais.

Nas vigas, ocorrências como a falta de estanqueidade da fôrmas seguem uma postura relacionada com o andamento da obra quando se refere ao reaproveitamento das fôrmas. Porém, em alguns edificios, a falta de estanqueidade das fôrmas surge desde o início da obra, retratando a postura da construtora quanto a essa questão. 
As considerações finais referentes às vigas é de que poucas construtoras encaram a questão das segregações como algo sério, pois apesar desse ponto ser sempre um tema de discussões, apenas três construtoras demostraram um cuidado um pouco maior na produção dos elementos estruturais (edificios B, F e H).

Infelizmente as estatísticas mostram que esse problema dificilmente será extinguido enquanto a conduta tomada na produção das construções não for reavaliada como pode-se observar no resumo geral das vigas apresentado na Tabela 29. 
TABELA 29 - Resumo das incidências observadas no elemento estrutural - viga em todos edifícios (continua)

\begin{tabular}{|c|c|c|c|c|c|c|c|c|c|c|c|c|}
\hline \multirow{2}{*}{$\begin{array}{l}\text { EDIFICIO } \\
\text { Tipo de manifestação patológica observada }\end{array}$} & \multicolumn{2}{|c|}{ Edifício A ( total $=294$ ) } & \multicolumn{2}{|c|}{ Edificio $B($ total $=420)$} & \multicolumn{2}{|c|}{ Edifício C ( total $=765$ ) } & \multicolumn{2}{|c|}{ Edifício $D($ total $=480)$} & \multicolumn{2}{|c|}{ Edifício $E($ total $=189$ ) } & \multicolumn{2}{|c|}{ Edificio $F($ total $=120$ ) } \\
\hline & $\$$ & $\%$ & $\$$ & $\%$ & $\$$ & $\%$ & $\$$ & $\%$ & $\$$ & $\%$ & $\$$ & $\%$ \\
\hline desaprumo & 0 & - & 0 & & 0 & & 0 & - & 0 & - & 0 & \\
\hline torçăo da fôrma & 1 & 0,34 & 14 & 3,33 & 22 & 2,88 & 12 & 2,50 & 0 & - & 0 & - \\
\hline junta de concretagem & 4 & 1,36 & 13 & 3,10 & 14 & 1,83 & 18 & 3,75 & 1 & 0,53 & 2 & 1,67 \\
\hline falta de limpeza das formas & 60 & 20,41 & 9 & 2,14 & 27 & 3,53 & 15 & 3,13 & 15 & 7,94 & 13 & 10,83 \\
\hline falta de estanqueidade das formas & 88 & 29,93 & 34 & 8,10 & 59 & 7,71 & 65 & 13,54 & 72 & 38,10 & 0 & - \\
\hline falta de limpeza nos elementos estruturais & 0 & - & 15 & 3,57 & 0 & - & 75 & 15,63 & 0 & - & 1 & 0,83 \\
\hline disgregaçăo & 4 & 1,36 & 1 & 0,24 & 0 & & 2 & 0,42 & 0 & - & 16 & 13,33 \\
\hline bicheiras & 2 & 0,68 & 20 & 4,76 & 30 & 3,92 & 10 & 2,08 & 5 & 2,65 & 1 & 0,83 \\
\hline segregaçăo do concreto & 166 & 56,46 & 136 & 32,38 & 131 & 17,12 & 133 & 27,71 & 56 & 29,63 & 7 & 5,83 \\
\hline falta de cobrimento de proteçao das armaduras & 204 & 69,39 & 64 & 15,24 & 209 & 27,32 & 195 & 40,63 & 96 & 50,79 & 48 & 40,00 \\
\hline efeito parede & 0 & & 0 & & 0 & - & 0 & - & 0 & - & 0 & - \\
\hline falta de alinhamento horizontal ou vertical & 16 & 5,44 & 50 & 11,90 & 42 & 5,49 & 61 & 12,71 & 16 & 8,47 & 15 & 12,50 \\
\hline carbonataçăo na superficie do concreto & 0 & - & 0 & - & 0 & - & 0 & - & 0 & - & 120 & 100,00 \\
\hline manchas de corrosăo ou armadura corroída & 55 & 18,71 & 21 & 5,00 & 2 & 0,26 & 4 & 0,83 & 1 & 0,53 & 0 & \\
\hline fissuras de retraçăo & 18 & 6,12 & 2 & 0,48 & 8 & 1,05 & 0 & - & 0 & - & 3 & 2,50 \\
\hline fissuras inclinadas & 0 & - & 0 & - & 0 & - & 0 & - & 0 & - & 14 & 11,67 \\
\hline fissuras em tubulaçăo & 20 & 6,80 & 25 & 5,95 & 6 & 0,78 & 55 & 11,46 & 0 & - & 12 & 10,00 \\
\hline fissuras verticais & 19 & 6,46 & 24 & 5,71 & 13 & 1,70 & 5 & 1,40 & 0 & - & 13 & 10,83 \\
\hline deformaçăo das fôrmas & 12 & 4,08 & 37 & 8,81 & 38 & 4,97 & 44 & 9,17 & 23 & 12,17 & 1 & 0,83 \\
\hline reparo nos el. estrut. devido segregaçőes & 0 & - & 20 & 4,76 & 11 & 1,44 & 1 & 0,21 & 0 & & 0 & \\
\hline lixiviaçăo & 1 & 0,34 & 3 & 0,71 & 1 & 0,13 & 0 & - & 0 & - & 13 & 10,83 \\
\hline eflorescências & 0 & - & 3 & 0,71 & 1 & 0,13 & 3 & 0,63 & 0 & - & 11 & 9,17 \\
\hline falta de vibraçăo & 0 & - & 0 & - & 0 & - & 3 & 0,63 & 0 & - & 0 & - \\
\hline desagregaçăo do concreto & 0 & - & 0 & - & 1 & 0,13 & 0 & - & 0 & - & 8 & 6,67 \\
\hline mal posicionamento da armadura & 0 & - & 0 & - & 0 & - & 0 & - & & & 0 & - \\
\hline
\end{tabular}

mal posicionamento da armadura

\$ - total de ocorrências observadas no edifício

$\%$ - porcentagem da incidência no edifício 
TABELA 29 - Resumo das incidências observadas no elemento estrutural - viga em todos edifícios (continuação)

\begin{tabular}{|c|c|c|c|c|c|c|c|c|c|c|c|c|}
\hline EDIFICIO & Edificio & $\mathrm{al}=360 \mathrm{~T}$ & Edifício & $\mathrm{al}=861)$ & Edificic & $T=396$ & Edificic & $a=290)$ & Edifícic & $a=144)$ & total de $\mathrm{v}$ & $s=4319$ \\
\hline Tipo de manifestação patológica observada & $\$$ & $\%$ & $\$$ & $\%$ & $\$$ & $\%$ & $\$$ & $\%$ & $\$$ & $\%$ & $\$$ & $\%$ \\
\hline desaprumo & 1 & 0,28 & 0 & - & 0 & & 0 & - & 0 & - & 1 & 0,02 \\
\hline torçăo da fôrma & 12 & 3,33 & 14 & 1,63 & 2 & 0,51 & 34 & 11,72 & 0 & - & 11 & 0,25 \\
\hline junta de concretagem & 8 & 2,22 & 10 & 1,16 & 1 & 0,25 & 17 & 5,86 & 0 & - & 88 & 2,04 \\
\hline falta de limpeza das fôrmas & 20 & 5,56 & 36 & 4,18 & 32 & 8,08 & 12 & 4,14 & 0 & - & 239 & 5,53 \\
\hline falta de estanqueidade & 16 & 4,44 & 262 & 30,43 & 37 & 9,34 & 9 & 3,10 & 53 & 36,81 & 695 & 16,09 \\
\hline falta de limpeza nos elementos estruturais & 24 & 6,67 & 5 & 0,58 & 24 & 6,06 & 0 & & 27 & 18,75 & 171 & 3,96 \\
\hline disgregaçăo & 39 & 10,83 & 72 & 8,36 & 20 & 5,05 & 2 & 0,69 & 0 & - & 156 & 3,61 \\
\hline bicheiras & 1 & 0,28 & 4 & 0,46 & 8 & 2,02 & 10 & 3,45 & 10 & 6,94 & 101 & 2,34 \\
\hline segregaçăo do concreto & 16 & 4,44 & 31 & 3,60 & 59 & 14,90 & 157 & 54,14 & 70 & 48,61 & 962 & 22,27 \\
\hline falta de cobrimento de proteçăo das armaduras & 150 & 41,67 & 522 & 60,63 & 119 & 30,05 & 54 & 18,62 & 64 & 44,44 & 1725 & 39,94 \\
\hline efeito parede & 0 & - & 0 & - & 0 & - & 0 & & 0 & - & 0 & - \\
\hline falta de alinhamento horizontal ou vertical & 97 & 26,94 & 82 & 9,52 & 31 & 7,83 & 26 & 8,97 & 19 & 13,19 & 455 & 10,53 \\
\hline carbonataçăo na superficie do concreto & 5 & 1,69 & 1 & 0,12 & 6 & 1,52 & 16 & 5,52 & 0 & - & 148 & 3,43 \\
\hline manchas de corrosăo ou armadura corroída & 176 & 48,89 & 34 & 3,95 & 76 & 19,19 & 21 & 7,24 & 0 & - & 390 & 9,03 \\
\hline fissuras de retraçăo & 0 & - & 5 & 0,58 & 0 & - & 1 & 0,34 & 0 & & 37 & 0,86 \\
\hline fissuras inclinadas & 0 & - & 0 & - & 0 & - & 2 & 0,69 & 0 & - & 16 & 0,37 \\
\hline fissuras em tubulaçăo & 0 & - & 59 & 6,85 & 0 & - & 15 & 5,17 & 0 & - & 192 & 4,45 \\
\hline fissuras verticais & 0 & - & 28 & 3,25 & 0 & - & 23 & 7,93 & 0 & - & 125 & 2,89 \\
\hline deformaçăo das fôrmas & 57 & 15,83 & 217 & 25,20 & 57 & 14,39 & 27 & 9,31 & 11 & 7,64 & 524 & 12,13 \\
\hline reparo nos el. estrut. devido segregaçōes & 0 & & 4 & 0,46 & 0 & & 14 & 4,83 & 0 & - & 50 & 1,16 \\
\hline lixiviação & 10 & 2,78 & 1 & 0,12 & 6 & 1,52 & 17 & 5,86 & 0 & - & 52 & 1,20 \\
\hline eflorescências & 10 & 2,78 & 0 & - & 5 & 1,26 & 15 & 5,17 & 0 & - & 48 & 1,11 \\
\hline falta de vibraçăo & 0 & - & 0 & - & 0 & - & 0 & - & 0 & - & 3 & 0,07 \\
\hline desagregaçắo do concreto & 0 & - & 0 & - & 0 & - & 1 & 0,34 & 0 & - & 10 & 0,23 \\
\hline armadura mal posicionada & 11 & 3,06 & & & 8 & 36,36 & & & & & 19 & 0,44 \\
\hline
\end{tabular}

$\$$ - total de ocorrências observadas no edifício

$\%$ - porcentagem da incidência no edifício 


\section{3-PILAR}

Computados os dados dos 2062 pilares observados no decorrer das obras visitadas, notou-se que esses elementos estruturais também exercem grande influência na compilação dos resultados como pode ser visto na Tabela 30.

Ao observar novamente a Tabela 27 , que apresenta a incidência e suas respectivas porcentagem por elementos observados para todos os edificios, a segregação apresenta o maior índice de ocorrências em relação a todas outras para esse elemento estrutural.

Ela lidera as estatísticas com $46,90 \%$, seguida da carbonatação da superficie de concreto com $20,95 \%$ e deformação das fôrmas com $12,56 \%$.

Em $95 \%$ dos elementos estruturais observados, a segregação sempre foi detectada nos pés dos pilares.

Apenas em alguns casos, as regiões segregadas localizavam-se na altura média destes elementos.

As causas prováveis para a segregação devem-se a problemas no momento das concretagens e principalmente às altas taxas de armadura de traspasse.

Quando se mencionam problemas no momento da concretagem, na verdade devese atribuir a problemas de projeto pois como elucidado no Capítulo 3 ,na existência de peças altas há a necessidade de prever aberturas nas faces laterais das fôrmas (cachimbos $\mathrm{e}$ janelas) locadas nas bases e alturas médias das fồmas.

Essa precaução tem duas finalidades: a primeira está em possibilitar a limpeza das fôrmas através das janelas locadas nas suas bases e a segunda está no fato de limitar a altura de queda do concreto ao ser lançado na fôrma. A Norma restringe essa altura em $2,00 \mathrm{~m}$.

Quando essas medidas não são adotadas, ao se lançar o concreto, ocorre desagregação do material fazendo o agregado graúdo separar-se da pasta e assentando primeiro na base. Isso dificulta a passagem da pasta pelo emaranhado agregado/armadura do pé do pilar. Além disso, é comum a presença de detritos na base que junta-se com esse concreto e faz a ligação topo de um pilar com a base do outro tornar-se uma mistura de concreto-sujeira-agregado graúdo-pasta-concreto.

Conforme a altura de lançamento vai diminuindo, essa tendência vai sendo eliminada fazendo o concreto retornar suas características de um material homogêneo. 
Em relação à existência de emendas por traspasse, alguns autores discutem a necessidade de deslocar essa armadura de espera dos seus eixos para a peça poder receber a ferragem longitudinal do próximo pavimento, evitando assim que essas armaduras ocupem a mesma posição (Fig. 13)

Com a adoção desse detalhe em projeto, garante-se que no momento de execução, os elementos estruturais não sejam deslocados de suas posições originais, mantendo o eixo do pilar ao longo de todo edificio, garantindo o prumo. Assim, evita-se outra incidência que é a falta de prumo. Além disso, pode-se eliminar alguns vícios da obra como o de dobrar a armadura de espera aleatoriamente para "sobrepor" a armadura longitudinal do próximo pavimento.

A alta taxa de armadura age como num efeito dominó, desencadeando inúmeros problemas no momento de executar a peça. É comum o concreto ser impedido de chegar nessas regiões por falta de espaço, a agulha do vibrador não consegue penetrar e a espessura da camada de cobrimento fica comprometida, pois falta espaço suficiente para a colocação de espaçadores pelo deslocamento da armadura longitudinal.

Esses fatores decorrentes do posicionamento e existência das emendas de traspasse geram as segregações chegando a situações mais críticas como a completa ausência do concreto caracterizadas pelas famosas "bicheiras".

A NB-1 fixa que para pilares não cintados a armadura longitudinal deve ter seção compreendida entre $0,8 \%$ e $6,0 \%$ da seção do pilar, inclusive nesses trechos de emendas de traspasse.

Uma possibilidade de contornar esse aumento de armadura nessas regiões esta em estabelecer duas fases diferentes de concretagem para os pilares.

A primeira fase consiste na chamada "imprimação da armadura dos pilares", ou seja, concretar essa região com um concreto ou um graute com as mesmas características de resistência especificadas para o pilar, empregando um pedrisco ao invés da brita 1 ou 2 e maior abatimento. Passada essa região de emenda, retorna-se a concretagem convencional.

Salienta-se que esse processo pode introduzir uma alteração no módulo de elasticidade no local, diferente do resto do elemento estrutural.

No caso dessa solução ser inviável, a simples postura do calculista de especificar um concreto compatível com a região de emendas, garantindo que o agregado graúdo 
empregado no concreto passe pelos espaços entre barras já é o suficiente para resolver o problema.

O processo mais correto é aquele em que para a aplicação do concreto, utiliza-se de funil, até a região de traspasse, aplicando-se camadas com altura útil de $3 / 4$ do comprimento da agulha do vibrador, com concreto formulado com agregado com dimensão máxima compatível com o arranjo da armadura adotada.

Apesar da restrição da Norma, ao se analisar os projetos estruturais dos edifícios, independente das suas ocorrências, pode-se verificar que em alguns pilares as regiões de emendas por traspasse chegam a atingir $8,30 \%$ de área de armadura excedendo em $2,30 \%$ os limites sendo que esse problema poderia ser resolvido facilmente com a adoção de outros concretos.

Isso eqüivale a um pilar com seção de $20 X 80 \mathrm{~cm}, \mathrm{~A}_{c}=1600 \mathrm{~cm}^{2}$, poder ter no máximo $96,00 \mathrm{~cm}^{2}$ de área de aço. Essa diferença conferida de $2,30 \%$ a mais na taxa de armadura representa um acréscimo de $36,80 \mathrm{~cm}^{2}$ que significa, por exemplo, área correspondente a 18 barras de $16 \mathrm{~mm}$ a mais nessa seção de pilar.

Sendo assim, são compreensíveis os grandes índices de segregação do concreto ocorridos nos pilares (erro de projeto ou projeto inexeqüível).

Ao longo dessas peças, nas suas alturas médias, a armadura longitudinal mantémse dentro dos parâmetros fixados, ficando a maioria em torno dos $3,00 \%$ de área de armadura.

No caso desses elementos estruturais fica dificil discorrer sobre os edificios com as maiores incidências de segregação registradas pois apesar dos edificios C, A, J e F respectivamente com $80,00 \%, 79,28 \%, 63,50 \%$ e $61,25 \%$ apresentarem alguns pilares com taxas de armaduras nas emendas superiores aos limites fixados, também apresentaram taxas de armadura dentro dos parâmetros aceitáveis.

Do mesmo modo, os edificios restantes (B, D, E, G e L) apesar de apresentarem valores entre $24,36 \%$ e $41,18 \%$ também continham pilares com taxas de armaduras nas regiões de traspasse superiores aos $6,00 \%$ da Norma.

Alguns calculistas adotam "coeficiente de segurança" em função da qualidade da mão-de-obra que irá executar a estrutura pensando, intuitivamente, que está adotando um fator de segurança a mais. Essa postura leva a um problema maior ainda, que é a fragilidade localizada no ponto de maior solicitação. Na maioria dos casos problemáticos, 
a resistência do concreto nesse local não atinge $10 \mathrm{MPa}$. $O$ problema tanto existe em vigas quanto em pilares.

Existem informações adicionais que são válidas de serem relatadas.

De todos os projetos analisados dos edifícios visitados, oito edificios salientam o uso de pastilhas espaçadoras, sendo que três deles $(\mathrm{G}, \mathrm{H}$ e I da mesma construtora, porém com projetos concebidos por escritórios diferentes) inclusive detalham em projeto o uso dos grampos quanto seus posicionamentos horizontal e vertical e referidos espaçamentos nas armaduras (tanto longitudinal quanto transversais) para que se evite o deslocamento e movimentação dessas armaduras no momento da execução.

Quanto ao problema das zonas de emendas, foram observados detalhes específicos em dois dos onze projetos analisados referentes ao deslocamento da armadura de espera nos traspasses para poder estabelecer a continuidade da armadura longitudinal (edificios $G$ e H), seguindo as recomendações, por exemplo, mostradas por RIPPER (1996) na Figura 13.

Outro detalhe que vale a pena ser mencionado é que apesar de todos os edificios conterem vazios para passagem de tubulações, embutidos, shafts, etc., só foram observados cuidados em detalhar reforços nas regiões dessas aberturas no projeto estrutural do edificio $\mathrm{H}$.

Todos os pilares observados em projeto sejam de canto, intermediários ou de extremidade, apresentaram espessura da camada de cobrimento de concreto de $1,50 \mathrm{~cm}$ independente da posição e $\mathrm{f}_{\mathrm{ck}}$ adotado.

Essa informação só foi destacada nas especificações de projeto estrutural do edificio E. Nos demais apresentou-se na forma de cortes das seções transversais das peças.

Contudo, como já foi exaustivamente elucidada a questão das taxas de armadura relacionadas com os arranques, deslocamento das armaduras e falta de espaço para colocação das fôrmas, vale comentar a questão das pastilhas associadas as conseqüências acima citadas.

Pode-se confirmar através dos resultados, que apesar dos relatos mencionarem o uso das pastilhas, as regiões dos pés dos pilares que estavam segregados acusam também a falta de cobrimento, aparecendo em alguns casos a completa exposição das armaduras pela ausência desta. Ou seja, concluindo a idéia, realmente os fatos estão intrinsecamente relacionados como se pode constatar nos checklists anexos. 
Quanto à carbonatação nas superficies dos pilares, os edificios F e I apresentaram valores aceitáveis e mais, compreensiveis.

Estes edificios, em especial o edificio E, encontra-se com suas obras paralisadas há cinco anos e sua estrutura está completamente exposta.

Associado a isso, analisando os ventos predominantes de São Carlos, que são de Nordeste, eles atingem toda fachada Leste da construção que em contrapartida não é circundada por nenhum tipo de barreira natural ou artificial (árvores, edificios, etc.) que sirvam de anteparo para a ação dos ventos.

Assim o $\mathrm{CO}_{2}$ da atmosfera reage com o hidróxido de cálcio das superfícies das peças formado pela hidratação da pasta e provoca a carbonatação.

A situação do edificio I é similar, diferindo apenas sob os aspectos das redondezas deste conterem outros edificios tão altos quanto ele, situados inclusive na lateral Leste servindo como proteção pois esta também é a face que recebe maior incidência dos ventos predominantes.

A redução dos índices de carbonatação nesse edificio reside no fato de que apesar da sua construção também estar paralisada, este tempo até o momento representa um ano. Além disso, devido à metodologia aplicada nos edificios dessa construtora, era prática comum chapiscar os elementos estruturais depois de executados. Essa conduta criou uma proteção nas peças, reduzindo assim a ação dos agentes deletérios na estrutura durante a duração da obra.

No entanto, em qualquer tipo de obra, nas regiões onde se detectaram defeitos na concretagem, o concreto na região da armadura estava carbonatado.

A respeito dos índices de deformação das fồrmas, a discussão recai sob os mesmos problemas já levantados nos casos das lajes e vigas.

Como informação complementar sobre esse assunto, foi comum observar que, pelo desgaste das fồrmas, havia uma grande preocupação com o fechamento das laterais destas, apertando-se excessivamente os tensores (dispositivos de travamento que prendem os tirantes até que estes cheguem na posição correta estabelecida pela largura da peça) a fim de impossibilitar possíveis deslocamentos das fôrmas nessas regiões ao se lançar o concreto e adensá-lo. 
O problema surgiu exatamente ao se tomar essa precaução, pois ao tensionar muito esses tirantes as peças saíam dos seus planos e, consequentemente, da verticalidade podendo esse fato ser notado nas peças concretadas, acusando deformações nessas regiões conforme a Figura 39.

FIGURA 39 - Falta de alinhamento lateral da parede devido deformação das fôrmas

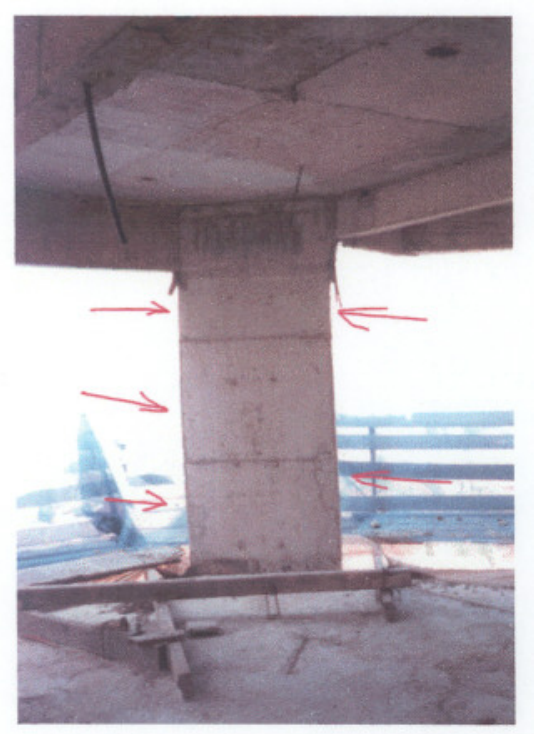

A questão da falta de alinhamento é um item importante pois, apesar de não apresentarem altas ocorrências no panorama final, apenas os edificios $\mathrm{A}, \mathrm{D}$ e $\mathrm{F}$ não acusaram ocorrências desse item. No entanto, ao analisar os projetos pôde-se observar que a maioria, submetidas a flexões oblíquas, apresentam-se como elementos de contraventamento sendo submetidos à ação dos ventos que aumenta os esforços sobre eles. 
TABELA 30 - Resumo das incidências observadas no elemento estrutural - pilar em todos edifícios (continua)

\begin{tabular}{|c|c|c|c|c|c|c|c|c|c|c|c|c|}
\hline \multirow{2}{*}{$\begin{array}{l}\text { EDIFICIO } \\
\text { Tipo de manifestação patológica observada }\end{array}$} & \multicolumn{2}{|c|}{ Edifício A ( total $=222$ ) } & \multicolumn{2}{|c|}{ Edifício B ( total =280) } & \multicolumn{2}{|c|}{ Edifício $C$ ( total $=150$ ) } & \multicolumn{2}{|c|}{ Edifício $D($ total $=204$ ) } & \multicolumn{2}{|c|}{ Edifício $E($ total $=140)$} & \multicolumn{2}{|c|}{ Edificio $\mathrm{F}($ total $=80)$} \\
\hline & $\$$ & $\%$ & $\$$ & $\%$ & $\$$ & $\%$ & $\$$ & $\%$ & $\$$ & $\%$ & $\$$ & $\%$ \\
\hline desaprumo & 0 & - & 27 & 9,64 & 2 & 1,33 & 0 & - & 0 & - & 3 & 3,75 \\
\hline torção da fôrma & 0 & - & 8 & 2,86 & 5 & 3,33 & 3 & 1,47 & 0 & - & 0 & - \\
\hline junta de concretagem & 0 & - & 1 & 0,36 & 0 & - & 0 & - & 0 & - & 6 & 7,50 \\
\hline falta de limpeza das fôrmas & 0 & - & 4 & 1,43 & 2 & 1,33 & 1 & 0,49 & 3 & 2,14 & 1 & 1,25 \\
\hline falta de estanqueidade das forrmas & 0 & - & 11 & 3,93 & 0 & - & 0 & - & 0 & - & 0 & - \\
\hline falta de limpeza nos elementos estruturais & 0 & - & 5 & 1,79 & 0 & - & 3 & 1,47 & 0 & - & 0 & - \\
\hline disgregaçăo & 0 & - & 2 & 0,71 & 1 & 0,67 & 0 & - & 0 & - & 1 & 1,25 \\
\hline bicheiras & 12 & 5,41 & 12 & 4,29 & 11 & 7,33 & 10 & 4,90 & 15 & 10,71 & 3 & 3,75 \\
\hline segregaçăo do concreto & 176 & 79,28 & 111 & 39,64 & 120 & 80,00 & 84 & 41,18 & 48 & 34,29 & 49 & 61,25 \\
\hline falta de cobrimento de proteçao das armaduras & 2 & 0,90 & 15 & 5,36 & 9 & 6,00 & 6 & 2,94 & 11 & 7,86 & 2 & 2,50 \\
\hline efeito parede & 2 & 0,90 & 0 & - & 0 & - & 0 & - & 0 & - & 0 & - \\
\hline falta de alinhamento horizontal ou vertical & 0 & - & 9 & 3,21 & 20 & 13,33 & 3 & 1,47 & 9 & 6,43 & 1 & 1,25 \\
\hline carbonataçăo na superfície do concreto & 0 & - & 0 & - & 0 & - & 0 & - & 0 & - & 80 & 100,00 \\
\hline manchas de corrosăo ou armadura corroída & 1 & 0,45 & 9 & 3,21 & 0 & - & 0 & - & 0 & - & 2 & 2,50 \\
\hline fissuras de retraçăo & 1 & 0,45 & 0 & - & 0 & - & 0 & - & 0 & - & 36 & 45,00 \\
\hline fissuras inclinadas & 0 & - & 0 & - & 0 & - & 0 & - & 0 & - & 0 & - \\
\hline fissuras em tubulação & 0 & - & 0 & - & 0 & - & 0 & - & 0 & - & 0 & - \\
\hline fissuras verticais & 0 & - & 0 & - & 0 & - & 0 & - & 0 & - & 0 & - \\
\hline deformação das fôrmas & 2 & 0,90 & 59 & 21,07 & 56 & 37,33 & 13 & 6,37 & 11 & 7,86 & 4 & 5,00 \\
\hline reparo nos el. estrut. devido segregaçōes & 0 & - & 22 & 7,86 & 5 & 3,33 & 15 & 7,35 & 4 & 2,86 & 2 & 2,50 \\
\hline lixiviaçăo & 0 & - & 0 & - & 0 & - & 0 & - & 0 & - & 2 & 2,50 \\
\hline eflorescências & 0 & - & 0 & - & 0 & - & 0 & - & 0 & - & 1 & 1,25 \\
\hline falta de vibração & 0 & - & 0 & - & 0 & - & 0 & - & 0 & - & 0 & - \\
\hline desagregação do concreto & 0 & - & 0 & - & 0 & - & 0 & - & 0 & - & 0 & - \\
\hline mal posicionamento da armadura & 0 & - & 0 & - & 0 & - & 0 & - & & & 0 & - \\
\hline
\end{tabular}

$\$$ - total de ocorrências observadas no edifício

$\%$ - porcentagem da incidência no edifício 
TABELA 30 - Resumo das incidências observadas no elemento estrutural - pilar em todos edifícios (continuação)

\begin{tabular}{|c|c|c|c|c|c|c|c|c|c|c|c|c|}
\hline \multirow{2}{*}{$\begin{array}{l}\text { EDIFICIO } \\
\text { Tipo de manifestação patológica observada }\end{array}$} & \multicolumn{2}{|c|}{ Edificio $G($ total $=390)$} & \multicolumn{2}{|c|}{ Edificio H ( total $=126$ ) } & \multicolumn{2}{|c|}{ Edificio $1($ total $=162)$} & \multicolumn{2}{|c|}{ Edificio J $($ total $=200$ ) } & \multicolumn{2}{|c|}{ Edificio $L($ total $=108)$} & \multicolumn{2}{|c|}{ total de pilares $=2062$} \\
\hline & $\$$ & $\%$ & $\$$ & $\%$ & $\$$ & $\%$ & $\$$ & $\%$ & $\$$ & $\%$ & $\$$ & $\%$ \\
\hline desaprumo & 2 & 0,51 & 0 & - & 1 & 0,62 & 0 & - & 0 & - & 35 & 1,70 \\
\hline torçấo da forma & 2 & 0,51 & 0 & - & 3 & 1,85 & 13 & 6,50 & 0 & - & 34 & 1,65 \\
\hline junta de concretagem & 0 & - & 0 & - & 0 & - & 13 & 6,50 & 0 & - & 20 & 0,97 \\
\hline falta de limpeza das formas & 1 & 0,26 & 17 & 13,49 & 1 & 0,62 & 0 & - & 0 & - & 30 & 1,45 \\
\hline falta de estanqueidade & 0 & - & 1 & 0,79 & 5 & 3,09 & 0 & - & 0 & - & 17 & 0,82 \\
\hline falta de limpeza nos elementos estruturais & 12 & 3,08 & 9 & 7,14 & 45 & 27,78 & 4 & 2,00 & 0 & - & 78 & 3,78 \\
\hline disgregaçắo & 18 & 4,62 & 5 & 3,97 & 0 & - & 0 & - & 0 & - & 27 & 1,31 \\
\hline bicheiras & 29 & 7,44 & 1 & 0,79 & 5 & 3,09 & 3 & 1,50 & 8 & 7,41 & 109 & 5,29 \\
\hline segregaçăo do concreto & 95 & 24,36 & 25 & 19,84 & 88 & 54,32 & 127 & 63,50 & 44 & 40,74 & 967 & 46,90 \\
\hline falta de cobrimento de proteçắo das armaduras & 59 & 15,13 & 7 & 5,56 & 3 & 1,85 & 5 & 2,50 & 0 & - & 119 & 5,77 \\
\hline efeito parede & 0 & - & 0 & - & 0 & - & 1 & 0,50 & 0 & - & 3 & 0,15 \\
\hline falta de alinhamento horizontal ou vertical & 19 & 4,87 & 32 & 25,40 & 13 & 8,02 & 8 & 4,00 & 30 & 27,78 & 144 & 6,98 \\
\hline carbonataçăo na superficie do concreto & 175 & 44,87 & 84 & 66,67 & 53 & 32,72 & 40 & 20,00 & 0 & - & 432 & 20,95 \\
\hline manchas de corrosăo ou armadura corroida & 61 & 15,64 & 6 & 4,76 & 2 & 1,23 & 6 & 3,00 & 0 & - & 87 & 4,22 \\
\hline fissuras de retraçắo & 0 & - & 0 & - & 0 & - & 0 & - & 6 & 5,56 & 43 & 2,09 \\
\hline fissuras inclinadas & 0 & - & 0 & - & 0 & $\cdot$ & 0 & - & 0 & - & 0 & - \\
\hline fissuras em tubulaçăo & 0 & - & 0 & - & 0 & - & 0 & - & 0 & $\cdot$ & 0 & - \\
\hline fissuras verticais & 0 & $\cdot$ & 0 & - & 0 & - & 0 & $\cdot$ & 0 & - & 0 & - \\
\hline deformaçấo das fôrmas & 17 & 4,36 & 43 & 34,13 & 19 & 11,73 & 25 & 12,50 & 10 & 9,26 & 259 & 12,56 \\
\hline reparo nos el. estrut. devido segregaçốes & 16 & 4,10 & 7 & 5,56 & 6 & 3,70 & 12 & 6,00 & 0 & - & 89 & 4,32 \\
\hline lixiviaçăo & 1 & 0,26 & 0 & - & 1 & 0,62 & 2 & 1,00 & 0 & - & 6 & 0,29 \\
\hline eflorescências & 1 & 0,26 & 0 & - & 1 & 0,62 & 3 & 1,50 & 0 & - & 6 & 0,29 \\
\hline falta de vibraçăo & 0 & - & 0 & - & 0 & - & 0 & - & 0 & - & 0 & - \\
\hline desagregaçăo do concreto & 0 & $\cdot$ & 0 & $\cdot$ & 0 & - & 0 & - & 0 & - & 0 & - \\
\hline armadura mal posicionada & 7 & 1,79 & & & 1 & 0,62 & & & & & 8 & 0,39 \\
\hline
\end{tabular}

$\$$ - total de ocorrências observadas no edificio

$\%$ - porcentagem da incidência no edifício 


\section{4 - PAREDE}

FUSCO (1986) elucida que, para efeito de dimensionamento, as paredes estruturais são tratadas da mesma forma que os pilares, alterando-se apenas alguns detalhes.

Da mesma forma que os pilares, as paredes acompanham a mesma tendência de segregação em regiões análogas às relatadas.

Os problemas que agravam o surgimento dessas ocorrências nas paredes são os mesmos que caracterizam os pilares. Sendo assim, para não tornar essa discussão repetitiva, serão abordados apenas alguns fatores adicionais não ressaltados nos casos dos pilares.

Ao observar o quadro de ocomências de cada edifício pela Tabela 31, reforça-se a idéia que as segregações não são problemas que aumentam com a evolução da construção, pois em todos os casos essas ocorrências surgem desde o princípio da obra e seguem até seu término, se tratando de um vício.

Quanto às altas porcentagens de problemas advindos da deformação das fồrmas, o assunto recai nos problemas que surgem desde a análise das lajes e passam por todos os elementos estruturais restantes.

O que sobressai nesse caso é que pelas próprias dimensões de uma parede serem maiores em relação aos pilares, por exemplo, tornam-se mais notórias as deformações das peças depois de concretadas.

Essa situação se dá ao fato dos painéis dessas fôrmas serem vibradas mais intensamente com o intuito de garantir uma boa compacidade. Essa postura se deve às dimensões geométricas da parede.

Com esse agravante próprio das paredes, aliado ao reaproveitamento das fồmas, esses painéis tendem a atingir uma deterioração mais acelerada que nos outros elementos.

Como já mencionado para o caso dos pilares, o caso do travamento desses painéis laterais junta-se com a questão das fồrmas já comprometidas quanto às suas características mecânicas, o que influencia definitivamente o resultado final das peças.

A conduta que os profissionais de canteiro tomam nesses casos é de tensionar os tirantes com os tensores até o limite, pois como as fồrmas já estão velhas, a preocupação destas abrirem no momento do lançamento do concreto fica descartada. 
Em tese, essa conduta seria o suficiente para funcionar, porém, na realidade, acontece que, pelas fôrmas estarem fracas, ao tensionar os tirantes, a região do painel que contém essa linha de travamento se deforma facilmente e em grande amplitude. Em contrapartida, o restante do painel de fechamento da fồrma que não contém essa linha vertical de travamento, incha, e se deforma no momento que recebe o concreto.

O resultado final só é percebido quando a peça é desformada e assume grande similaridade com uma "sanfona", pois ao longo do seu comprimento percebem-se regiões onde o concreto entra e, em outras, sai em relação ao plano de suas superficies verticais conforme Figura 40.

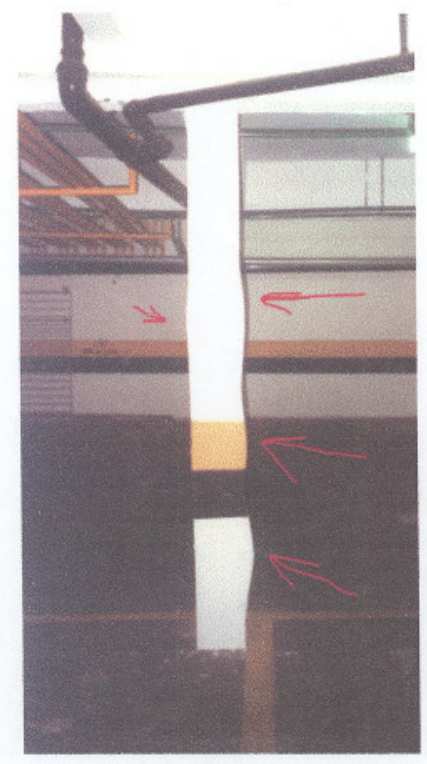

\section{FIGURA 40 - Laterais fora de alinhamento devido excesso de pressão nos tensores das fôrmas.}

Uma premissa, não citada até então, é o fato de um grande número de paredes acusarem falta de alinhamento vertical ao longo dos pavimentos.

Apesar de no panorama final a porcentagem por falta de alinhamento significar algo em torno dos 7,50\%, edifícios como o B e E apresentaram esse problema ao longo de toda sua estrutura. Edificios como o A, C, H, I e J também acusam esse tipo de problema em alguns de seus pavimentos.

Independente da questão de algumas dessas paredes estarem servindo como elementos de contraventamento e a grande maioria estar contraventada por outros constituintes da estrutura global, esses elementos desempenham importante função na estabilidade da estrutura no seu conjunto. 
De modo geral, o dimensionamento das paredes estruturais é feito considerando que a carga tenha uma excentricidade em relação ao plano médio da peça.

Essas excentricidades levam em consideração a inicial, a acidental e, de $2^{\mathrm{a}}$ ordem.

A questão é saber até que ponto essa excentricidade acidental, que é a responsável pelas prováveis imprecisões que por ventura ocorram na execução, estejam próximas de retratar as reais imprecisões de execução de modo a garantir a integridade desses elementos ao longo da vida útil da estrutura. 
TABELA 31 - Resumo das incidências observadas no elemento estrutural - parede em todos edifícios (continua)

\begin{tabular}{|c|c|c|c|c|c|c|c|c|}
\hline \multirow{2}{*}{$\begin{array}{l}\text { E D I F I C I O } \\
\text { Tipo de manifestação patológica observada }\end{array}$} & \multicolumn{2}{|c|}{ Edificio $A($ total $=12$ ) } & \multicolumn{2}{|c|}{ Edificio B ( total = 224 ) } & \multicolumn{2}{|c|}{ Edificio C ( total $=150$ ) } & \multicolumn{2}{|c|}{ Edifício $\mathrm{D}($ total $=108$ ) } \\
\hline & $\$$ & $\%$ & $\$$ & $\%$ & $\$$ & $\%$ & $\$$ & $\%$ \\
\hline desaprumo & 0 & - & 4 & 1,79 & 1 & 0,67 & 0 & - \\
\hline torção da fôrma & 0 & - & 5 & 2,23 & 6 & 4,00 & 0 & \\
\hline junta de concretagem & 0 & - & 8 & 3,57 & 1 & 0,67 & 3 & 2,78 \\
\hline falta de limpeza das fôrmas & 0 & - & 2 & 0,89 & 1 & 0,67 & 1 & 0,93 \\
\hline falta de estanqueidade das fôrmas & 0 & - & 17 & 7,59 & 10 & 6,67 & 1 & 0,93 \\
\hline falta de limpeza nos elementos estruturais & 0 & - & 8 & 3,57 & 0 & - & 6 & 5,56 \\
\hline disgregação & 0 & - & 2 & 0,89 & 0 & 0,67 & 0 & - \\
\hline bicheiras & 3 & 25,00 & 8 & 3,57 & 21 & 14,00 & 12 & 11,11 \\
\hline segregação do concreto & 10 & 83,33 & 81 & 36,16 & 108 & 72,00 & 86 & 79,63 \\
\hline falta de cobrimento de proteçao das armaduras & 2 & 16,67 & 15 & 6,70 & 3 & 2,00 & 4 & 3,70 \\
\hline efeito parede & 0 & & 0 & - & 0 & - & 0 & - \\
\hline falta de alinhamento horizontal ou vertical & 3 & 25,00 & 19 & 8,48 & 8 & 5,33 & 3 & 2,78 \\
\hline carbonatação na superfície do concreto & 0 & - & 0 & - & 0 & - & 0 & - \\
\hline manchas de corrosão ou armadura corroída & 0 & & 16 & 7,14 & 1 & 0,67 & 0 & - \\
\hline fissuras de retração & 0 & & 0 & - & 0 & - & 0 & - \\
\hline fissuras inclinadas & 0 & - & 0 & - & 0 & - & 0 & - \\
\hline fissuras em tubulação & 0 & - & 0 & - & 0 & - & 0 & - \\
\hline fissuras verticais & 0 & - & 0 & - & 0 & - & 0 & - \\
\hline deformação das fôrmas & 1 & 8,33 & 27 & 12,05 & 18 & 12,00 & 30 & 27,78 \\
\hline reparo nos el. estrut. devido segregaçöes & 0 & - & 41 & 18,30 & 5 & 3,33 & 20 & 18,52 \\
\hline lixiviação & 0 & - & 0 & - & 0 & - & 0 & - \\
\hline eflorescências & 0 & - & 0 & - & 0 & - & 0 & - \\
\hline falta de vibração & 0 & - & 0 & - & 0 & - & 0 & - \\
\hline desagregação do concreto & 0 & - & 0 & - & 0 & - & 0 & - \\
\hline mal posicionamento da armadura & 0 & - & 0 & - & 0 & - & 0 & - \\
\hline
\end{tabular}

\$ - total de ocorrências observadas no edifício

$\%$ - porcentagem da incidência no edifício 
TABELA 31 - Resumo das incidências observadas no elemento estrutural - parede em todos edifícios (continuação)

\begin{tabular}{|c|c|c|c|c|c|c|c|c|c|c|}
\hline EDIFICIO & Edifici & $\mathrm{tal}=56$ ) & Edifícic & $\mathrm{al}=336$ & Edific & $\mathrm{al}=90$ ) & Edific & tal $=50$ ) & total de & $s=1026$ \\
\hline Tipo de manifestação patológica observada & $\$$ & $\%$ & $\$$ & $\%$ & $\$$ & $\%$ & $\$$ & $\%$ & $\$$ & $\%$ \\
\hline desaprumo & & & 0 & - & 0 & & 2 & 4,00 & 7 & 0,68 \\
\hline torção da fôrma & & & 0 & - & 0 & & 5 & 10,00 & 16 & 1,56 \\
\hline junta de concretagem & & - & 0 & - & 0 & - & 8 & 16,00 & 20 & 1,95 \\
\hline falta de limpeza das fôrmas & 2 & 3,57 & 28 & 8,33 & 0 & & 2 & 4,00 & 36 & 3,51 \\
\hline falta de estanqueidade & 13 & 23,21 & 6 & 1,79 & 0 & & 15 & 30,00 & 62 & 6,04 \\
\hline falta de limpeza nos elementos estruturais & 0 & & 9 & 2,68 & 16 & 17,78 & 4 & 8,00 & 43 & 4,19 \\
\hline disgregação & 0 & & 0 & & 0 & - & 0 & - & 2 & 0,19 \\
\hline bicheiras & 6 & 10,71 & 7 & 2,08 & 11 & 12,22 & 25 & 50,00 & 93 & 9,06 \\
\hline segregaçäo do concreto & 36 & 64,29 & 62 & 18,45 & 47 & 52,22 & 64 & 128,00 & 494 & 48,15 \\
\hline falta de cobrimento de proteção das armaduras & 8 & 14,29 & 5 & 1,49 & 4 & 4,44 & 3 & 6,00 & 44 & 4,29 \\
\hline efeito parede & 0 & - & 0 & - & 0 & - & 0 & & 0 & - \\
\hline falta de alinhamento horizontal ou vertical & 11 & 19,64 & 23 & 6,85 & 4 & 4,44 & 6 & 12,00 & 77 & 7,50 \\
\hline carbonatação na superfície do concreto & 0 & & 0 & & 0 & & 8 & 16,00 & 8 & 0,78 \\
\hline manchas de corrosão ou armadura corroída & 1 & 1,79 & 9 & 2,68 & 3 & 3,33 & 7 & 14,00 & 37 & 3,61 \\
\hline fissuras de retração & 0 & - & 0 & - & 0 & - & 0 & - & 0 & - \\
\hline fissuras inclinadas & 0 & - & 0 & - & 0 & - & 0 & - & 0 & - \\
\hline fissuras em tubulação & 0 & - & 0 & - & 0 & - & 0 & - & 0 & - \\
\hline fissuras verticais & 0 & - & 0 & - & 0 & - & 2 & 4,00 & 2 & 0,19 \\
\hline deformação das fôrmas & 17 & 30,36 & 38 & 11,31 & 6 & 6,67 & 65 & 130,00 & 202 & 19,69 \\
\hline reparo nos el. estrut. devido segregaçōes & 0 & & 8 & 2,38 & 3 & 3,33 & 98 & 196,00 & 175 & 17,06 \\
\hline lixiviação & 0 & & 0 & - & 0 & & 4 & 8,00 & 4 & 0,39 \\
\hline eflorescências & 0 & & 0 & - & 0 & & 1 & 2,00 & 1 & 0,10 \\
\hline falta de vibração & 0 & - & 0 & - & 0 & - & 0 & - & 0 & - \\
\hline desagregação do concreto & 0 & - & 0 & - & 0 & - & 0 & - & 0 & - \\
\hline armadura mal posicionada & 0 & & & & 0 & & 0 & & 0 & - \\
\hline
\end{tabular}

\$ - total de ocorrências observadas no edifício

$\%$ - porcentagem da incidência no edifício 


\section{CONCLUSÕES}

Após toda a verificação da problemática relacionada com a construção de edifícios, o presente material possibilita o estabelecimento dos seguintes juízos:

- as obras visitadas denunciaram que há carência e/ou erros de especificação nos projetos quanto ao atendimento às exigências da NB-1;

- as obras apresentam falhas e erros na execução. Alguns procedimentos adotados não respeitam normas simples de conduta na prática da Construção Civil;

- é prática comum não ser realizada a verdadeira cura do concreto;

- por causa das rotinas praticadas, o maior problema observado nas estruturas de concreto armado em geral é a segregação do concreto;

- analisando separadamente, os elementos estruturais pilares e paredes predominam os casos de segregação do concreto;

- nas vigas de concreto armado, a maior incidência é a falta da camada de cobrimento de proteção das armaduras;

- em lajes, a ocorrência dominante é a falta de estanqueidade das fôrmas;

- os problemas verificados na fase de construção são pontos potenciais de desencadeamento de patologias futuras, de outras naturezas, porém com causas simples e que facilmente poderiam ser evitadas;

- os custos futuros advindos desses erros poderão ser significativos, em vista da interferência de outros subsistemas e pelo próprio uso;

- quanto mais cedo forem realizadas as terapias, menor serão os custos e efeitos produzidos;

- a reciclagem de conhecimentos e técnicas são cada vez mais necessárias, face às garantias do produto ao usuário;

- não se pode dissociar estrutura do comportamento de materiais frente ao meio ambiente e micro-climas encontráveis nas construções; 
- a compatibilidade entre materiais, subsistemas envolvidos, e a utilização deve ser previsto no projeto;

- as recomendações aos usuários na utilização do produto construção, face às diferenças existentes entre seus componentes devem ser formalmente notificadas;

- a prática da construção civil deve ser feita por equipe de profissionais, com total entendimento de todas as atividades envolvidas, restrições e diretrizes, de forma a permitir sua exequibilidade a fim de que todo o investimento seja duradouro e esteja em conformidade com as necessidades dos usuários.

\section{PROPOSTAS FUTURAS}

Finalmente, em vista de tantas variáveis observadas com a realização da presente pesquisa é notória a necessidade de novos estudos serem desenvolvidos sobre o assunto, de forma a possibilitar um melhor entendimento e reconhecimento dos pontos que precisam ser reajustados no setor, de maneira a melhorar a qualidade das construções. Desse modo propõe-se a seguir algumas possíveis linhas de pesquisa a dar continuidade e complementar esse trabalho, sendo algumas dessas propostas:

- a implantação de programas de monitoramento "in loco" dos concretos aplicados na obra para verificar os quesitos mínimos de durabilidade;

- a avaliação a nível nacional quanto a realidade das Patologias comumente existentes, a fim de estabelecer uma possível associação de incidências patológicas com as diferentes regiões do país;

- a pesquisa que evidencie as interferências das Patologias nos outros subsistemas de uma edificação;

- a determinação da velocidade dos estágios de degradação dessas Patologias nos edifícios, nos seus estados de serviço;

- a criação, estabelecimento e padronização de rotinas mínimas de trabalho que devem ser seguidas comumente por calculistas e engenheiros de obras, na forma de instrumentos de consulta;

- o estabelecimento do planejamento como premissa básica de toda e qualquer construção, de modo que este possa ser refletido em qualquer instância da obra. 


\section{REFERÊNCIAS BIBLIOGRAFICAS}

*aMERICAN CONCRETE INSTITUTE (1991) - Guide to Durable Concrete: reported by ACI Committee 201. ACI Materials Journal, v. 88, nº 5 , p. 544-82. AMERICAN SOCIETY FOR TESTING AND MATERIALS (1986) - ASTM C642. Standard Test Method for Specific Gravity, Absorption and Voids in Hardened Concrete. In: Annual Book of ASTM Standards. Philadelphia. ANDRADE, J. (1997) - Durabilidade das Estruturas de Concreto Armado: Análise das Manifestações Patológicas nas Estruturas no Estado de Pernambuco. Porto Alegre. 148p. Dissertação (Mestrado) - Universidade Federal do Rio Grande do Sul.

ARANHA, P.M.S. (1994) - Contribuição ao Estudo das Manifestações Patológicas nas Estruturas de Concreto Armado na Região Amazônica. Porto Alegre, 144p. Dissertação (Mestrado) - Universidade Federal do Rio Grande do Sul. ASSOCIAÇÃO BRASILEIRA DE NORMAS TÉCNICAS (1982). NBR 6118 (NB-1) Projeto e Execução de Obras de Concreto Armado. Rio de Janeiro. ASSOCIAÇÃO BRASILEIRA DE NORMAS TÉCNICAS (1996). NBR 7480 - Barras e Fios de Aço Destinados a Armaduras para Concreto Armado. Rio de Janeiro. ASSOCIAÇÃO BRASILEIRA DE NORMAS TÉCNICAS (1992). NBR 8953 Concreto para Fins Estruturais - Classificação por Grupos de Resistência. Rio de Janeiro.

ASSOCIAÇÃO BRASILEIRA DE NORMAS TÉCNICAS (1986). NBR 9778 -

Argamassa e Concreto Endurecidos - Determinação da Absorção de Água por Imersão - Índice de Vazios e Massa Especifica. Rio de Janeiro. 
ASSOCIAÇÃO BRASILEIRA DE NORMAS TÉCNICAS (1986). NBR 9779 Argamassa e Concreto Endurecidos - Determinação de Absorção de Água por Capilaridade. Rio de Janeiro.

ASSOCIAÇÃO BRASILEIRA DE NORMAS TÉCNICAS (1988). NBR 10787 Concreto Endurecido - Determinação da Penetração de Água sob Pressão. Rio de Janeiro.

BAUER, L. A. F. (1985) - Materiais de Construção. Rio de Janeiro. Livros Técnicos e Científicos, $3^{\mathrm{a}}$ ed.

BLEVOT, J. (1974) - Pathologie des Construtions en Beton Armé - Institut Techique du Bâtiment et Travaux Publics. Paris.

BRANDÃO, A. M. S. (1998) - Qualidade e Durabilidade das Estruturas de Concreto Armado: Aspectos Relativos ao Projeto. São Carlos. 137p. Dissertação (Mestrado) - Escola de Engenharia de São Carlos, Universidade de São Paulo.

*CÁNOVAS, M.F. (1977) - Patologia y Terapeutica del Hormigon Armado. Madrid, Dossat,. 392p.

CANOVAS, M. F. (1988)- Patologia e Terapia do Concreto Armado; In: $11^{0}$ Simpósio de Aplicação e Tecnologia do Concreto. São Paulo. Resumos. Concrelix S.A.

CARMONA FILHO, A.; MAREGA, A. (1988) - Retrospectiva de la Patologia en el Brasil: Estudio Estadistico. In: Trabajos Apresentados en la Jornada Español e Potuques sobre Estructuras y Materiales. Madrid, 1988. Anais. Madrid: CEDEX/ICcET, p. 99-124.

COMMITTEE EURO-INTERNATIONAL du BETON. (1993) - CEB-FIP Model Code 1990. Design Code., CEB, 437p. - Bulletin D'Information, 213-214, Lausanne.

COMPANHIA DE TECNOLOGIA DE SANEAMENTO AMBIENTAL (1978) Cetesb L1.007 - Agressividade do Meio ao Concreto: Classificação. São Paulo. DAL MOLIN, D.C.C. (1988) - Fissuras em Estruturas de Concreto Armado: Análise das Manifestações Típicas e Levantamento de Casos Ocorridos no Estado do Rio Grande do Sul. Porto Alegre, 220p. Dissertação (Mestrado) Universidade Federal do Rio Grande do Sul. 
DINIZ, J. Z. F. (1998) - A NB-1 - Visão Nacional da Durabilidade do Concreto - In: Simpósio sobre Durabilidade do Concreto- Ibracon / Escola Politécnica - USP 31/03/98, São Paulo.

EUROPEAN COMMITTEE OF STANDARDIZATION (1991) - Concrete:

Performance, Production, Placing and Compliance Criteria. ENV 206. s. 1., CEN.

FUSCO, P. B. (1986) - Estruturas de Concreto: Solicitações Normais; Estados Limites Últimos; Teoria e Aplicações. Rio de Janeiro. Guanabara Dois.

*GIONGO, J S. ; SILVA, R. C. (1994) - Concreto Armado: Estados Limites de Utilização. São Carlos./ Relatório Técnico EESC-USP.

¥HELENE, P. R. L. (1986) - Corrosão em Armaduras para Concreto Armado - São Paulo, Pini.

¥ HELENE, P. R. L. (1987a) - Durabilidade do Concreto versus Agressividade do Meio (1ª Parte) - São Paulo, Pini, IPT/DEd 43 p.87-90: Tecnologia de Edificações.

HELENE, P. R. L.; TERZIAN. P. (1992) - Manual de Dosagem e Controle do Concreto - São Paulo, Pini.

*HELENE, P. R. L. (1993) - Contribuição ao Estudo da Corrosão em Armaduras de Concreto Armado. São Paulo. 231p. Tese (Livre Docência) - Departamento de Engenharia de Construção Civil da Escola Politécnica, Universidade de São Paulo.

HELENE, P. R. L. (1998) - Introdução a Prevenção da Corrosão das Estruturas no

Projeto das Estruturas de Concreto - Avanços e Recuos In: Simpósio sobre Durabilidade do Concreto- Ibracon / Escola Politécnica-USP - 31/03/98, São Paulo.

INTERNATIONAL STANDARD ORGANIZATION (1984). NBR ISO- DP 6241 Performance Standards in Buildings: Principles for their Preparation and Factors to be Considered. Geneve.

INTERNATIONAL STANDARD ORGANIZATION (1992). NBR ISO 9002 - Sistema

da Qualidade: Modelo para Garantia da Qualidade em Produção e Instalação. s.1., ISO.

KIHARA,Y; NETO,C. S.; KUPERMAN, S. C.(1998) - Reação álcalis-agregado:

Visão Atual e a Situação Brasileira - In: Simpósio sobre Durabilidade do Concreto- Ibracon / Escola Politécnica-USP - 31/03/98, São Paulo. 
LEITE, A. R. C. A. P.; SAAD, M. N. a (1992) - Deterioração de Estruturas de Concreto - Principais Causas e Medidas Preventivas - Curitiba, IBRACON.

LIBÓRIO, J. B. L. (1989) - Estudo Patológico das Construções de Argamassa Armada Existentes no Brasil. São Carlos. 319p. Tese (Doutorado) - Escola de Engenharia de São Carlos, Universidade de São Paulo.

LIBORIO, J. B. L; MELO, A. B. (1994) - Notas de aula - SAP-503 "Patologia das Estruturas de Concreto", SAP-817 "Patologia das Construções". EESC-USP.

LIBÓRIO, J. B. L.; DOREA, S. C. L. (1996)-Reabilitação de Estruturas de Concreto Armado: Uma Análise Anterior à sua Ocorrência. In: $38^{\circ}$ Reibrac - Ibracon, Ribeirão Preto, 1996. Anais. v. 1, p. 357-368

LICHTENSTEIN, N. B. (1985) - "Patologia das Construções - Procedimento para formulação do diagnóstico de falhas e definição de conduta adequada a recuperação de edificações. São Paulo. 185p. Dissertação (Mestrado) - Escola Politécnica da Universidade de São Paulo, São Paulo.

\MEHTA, P. K; MONTEIRO, J. M. (1994) - Concreto: Estrutura, Propriedades e Materiais - São Paulo, Pini.

NEVILle, A. M. (1982) - Propriedades do Concreto. - Tradução de Salvador Eugênio Giammusso. São Paulo. Pini..

* OliveirA, P. S. F.; HELENE, P. R. L. (1991) - Proteção e Manutenção das Estruturas de Concreto - São Paulo, Revista Engenharia n. 485, p. 11-26.

OLIVIER, J. P. (1998) - Durability of Concrete - Labotatoire Materiaux et Durabilite des Construtions, INSA- UPS. Curso ministrado na Escola Politécnica da Universidade de São Paulo; 22/03 a 02/04/1998. São Paulo.

ORLANDI, S. A. F. (1983) - Notas de aula do curso "Formulação de Projeto para a Obra de Construção Civil”. EPUSP. São Paulo.

PALERMO, G. (1995) - Durabilidade e Estanqueidade. Revista Téchne, n 18, p. 32 36, São Paulo. Pini.

PAULON, A. V. (1996) - Interface entre pasta de cimento e agregado: A Influência da Durabilidade dos Concretos. - Revista Téchne, n 25, p. 29-31, São Paulo. Pini. 
POWERS, T. C. (1958) - Structure and Physical Properties of Hardened Portland Cement Paste. Journal of the American Ceramic Society. Chicago. v. 41, $\mathrm{n}^{\circ} 01, \mathrm{p}$. $1-6$.

REUNION DES LABORATOIRES D'ESSAIS ET MATERIAUX (1976) - RILEM. Corrosion of Reinforcement in Concrete - 12 Committee. Corrosion of Reinforcement and Prestressing Tendons: a State of Art Report. Materiaux et Constructions. Paris. v. 9, no 51, p. 187-206.

REUNION DES LABORATOIRES D'ESSAIS ET MATERIAUX (1988) - RILEM, CPC 18. Measurement of Hardened Concrete Carbonation Depth. Materials and Strutctures. Paris. v. 21, $\mathrm{n}^{\circ} 126$, p. 435-5.

RIPPER, E. (1996) - Como Evitar Erros na Construção. São Paulo, Pini, 3. Ed.

SOBRAL, H. S. (1990) - Durabilidade dos Concretos. - Estudo Técnico da Associação Brasileira de Cimento Portland, $n^{\circ}$ 43. São Paulo. ABCP.

THOMAZ, E. (1989) - Trincas em Edifícios: causas, prevenção e recuperação. São Paulo, Pini.

TREVISAN AUDITORES; CIC; ROSENBERG \& ASSOCIADOS (1997) -

Construbusiness - 1. Seminário da Indústria Brasileira da Construção - São Paulo, Comissão da Indústria da Construção da FIESP, CIESP, IRS.

TUUTTI, K. (1982) - Corrosion of Steel in Concrete. Stockholm, Swedish Cement and Concrete Research Institute, p. 17-21.

VOGEL, A. I. (1981) - Química Analítica Qualitativa. São Paulo, Mestre Jou. Capítulo 1. p-16: Soluções Aquosas de Substâncias Inorgânicas; p. 46 - 70: Teoria Clássica das Reações Acido - Base. 


\section{1 - BIBLIOGRAFIA COMPLEMENTAR}

ASSOCIAÇÃO BRASILEIRA DE CIMENTO PORTLAND (1992) - Vocabulário de

Teoria das Estruturas - boletim técnico/92 ; São Paulo, ABCP.

ASSOCIAÇÃO BRASILEIRA DE NORMAS TÉCNICAS (1977). NBR 05672 -

Diretrizes para o Controle Tecnológico de Materiais Destinados a Estruturas de Concreto. Rio de Janeiro.

ASSOCIAÇÃO BRASILEIRA DE NORMAS TÉCNICAS (1977). NBR 05673 -

Diretrizes para o Controle Tecnológico de Processos Executivos em Estruturas de Concreto. Rio de Janeiro.

ASSOCIAÇÃO BRASILEIRA DE NORMAS TÉCNICAS (1975). NBR 05750 Amostragem de Concreto Fresco Produzido por Betoneiras Estacionárias. Rio de Janeiro.

ASSOCIAÇÃO BRASILEIRA DE NORMAS TÉCNICAS (1992). NBR 07223 Concreto - Determinação da Consistência pelo Abatimento do Tronco de Cone. Rio de Janeiro.

ASSOCIAÇÃO BRASILEIRA DE NORMAS TÉCNICAS (1989). NBR 10786 Concreto Endurecido - Determinação do Coeficiente de Permeabilidade a Água. Rio de Janeiro.

ASSOCIAÇÃO BRASILEIRA DE NORMAS TÉCNICAS (1992). NBR 12654 -

Controle Tecnológico de Materiais Componentes do Concreto. Rio de Janeiro. ASSOCIAÇÃO BRASILEIRA DE NORMAS TÉCNICAS (1992). NBR 12655 -

Preparo, Controle e Recebimento de Concreto - Procedimento. Rio de Janeiro. CEOTTO, L. H. (1998) - Rebelde com Causa. Revista Téchne, n 32, pg. 10-12. São Paulo. Pini. 
CONSELHO REGIONAL DE ENGENHARIA E ARQUITETURA (1990) - Código de

Proteção e Defesa do Consumidor / Manual do Profissional. Lei n⿳ 8.078 de 11/09/1990. Artigo $2^{\circ}$ itens A e C, pg. 51 e item 26, pg. 46. São Paulo.

CUNHA, A. J. P. ; SOUZA, V. C. M.; LIMA, N. A. (1996)-Acidentes Estruturais na

Construção Civil. Volume I. São Paulo. Pini.

FERREIRA, A. B. H. ( 1993 ) - Dicionário da Língua Portuguesa - Rio de Janeiro, 3.

Ed. , Nova Fronteira.

FERREIRA, O. P.; LIBÓRIO, J. B. L.; SILVA, I. J. (1996) - Algumas Aplicações para

Resina Poliuretana Derivada de Óleo de Mamona para Proteção de

Estruturas de Concreto. In: $38^{\circ}$ Reibrac - Ibracon, Ribeirão Preto, 1996. Anais. v. 1, p. $343-356$.

FILHO, N. G. R (1989) - Aspectos da História da Engenharia Civil em São Paulo 1860-1960. Fundação Emílio Odebrecht/CBPO. São Paulo. Livraria Cosmos.

FLAUZINO, W. D. (1983) - Durabilidade de Materiais e Componentes das

Edificações. Dissertação de mestrado apresentada à Escola Politécnica da Universidade de São Paulo. São Paulo.

HELENE, P. R. L. (1987b) - Durabilidade do Concreto versus Agressividade do Meio (2 $2^{a}$ Parte ) - São Paulo, Pini, IPT/DEd 44 p.91-94: Tecnologia de Edificações.

HELENE, P. R. L. (1992)- Manual para Reparo, Reforço e Proteção de Estruturas de Concreto - São Paulo, Pini.

HELENE, P. R. L.; TERZIAN, P. (1992)- Manual de Dosagem e Controle do Concreto. Pini. São Paulo.

HELENE, P. R. L. ; FIGUEIREDO, E. P. (1994) - Assim caminha a Corrosão. Revista Téchne, n $^{\circ} 10$, São Paulo. Pini.

KISS, P. (1998) - Sistemas de Qualidade - Resultados na Obra. Revista Téchne, no 34, pg. 18-23. São Paulo. Pini.

LIBÓRIO, J. B. L. (1991) - Estruturas de Argamassa Armada: Principais Defeitos e Causas. In XXV Jornadas Sul Americanas de Engenharia Estrutural, Rio Grande do Sul, 1991. Anais. v. 5, p. 349-360. 
LIBÓRIO, J. B. L.; SILVA, I. J.; MELO, A. B.; AMARAL, C., K. (1997) - Alguns

Cuidados a serem Observados na Execução de Pisos Industriais e Elementos Estruturais de Edifícios em Concreto de Alto Desempenho. In: $39^{\circ}$ Reibrac Ibracon, São Paulo, 1997. Anais. v. 2, p. 483-498.

MATTEI, J. A. (1998) - A ISO-9000 aplicada à Construção Civil. Revista Téchne, $\mathbf{n}^{\circ}$ 34, pg. 24-25. São Paulo. Pini..

PEREZ. A. R. (1987) - Manutenção dos Edifícios. IPT/Ded, Tecnologia de Edificações, $\mathrm{n}^{\circ}$ 42, p.83-86. São Paulo, Pini.

PINHEIRO, L. M. (1993) - Concreto Armado: Tabelas e Ábacos. Departamento de Estruturas, São Carlos. publicações EESC/USP.

PINHEIRO, L. M; HELBIG, D. (1996) - Hipóteses de Cálculo na Ruína ; Notas de Aula; SET-862 - Fundamentos de Concreto I, EESC/USP.

SINDICATO DA INDÚSTRIA DA CONSTRUÇÃO PESADA DO ESTADO DE SÃO PAULO (1993) - A História do Desafio de Construir São Paulo. São Paulo. Estação Liberdade.

TACLA, Z. ( 1984 ) - O Livro da Arte de Construir- São Paulo, Unipress.

UNIVERSIDADE DE SÃO PAULO (1996) - Diretrizes para Elaboração de Dissertações e Teses na EESC-USP. São Carlos. Serviço de Bỉblioteca, 2. ed. rev. e ampl.

VIEIRA, S.(1991) - “Como Escrever uma Tese”. São Paulo, Pioneira. 
ANEXO A - Tabelas quantitativas das ocorrências de cada elemento estrutural do Edifício A 


\section{Elemento estrutural - LAJE}

Número de elementos estruturais (laje) por pavimento $=15$

@ = número de manifestações patológicas por pavimento

$\%$ = porcentagem de manifestaçōes patológicas por pavimento

\begin{tabular}{|c|c|c|c|c|c|c|c|c|c|c|c|c|}
\hline \multirow{2}{*}{$\begin{array}{l}\text { PAVIMENTO } \\
\text { Tipo de manifestação patológica observada }\end{array}$} & \multicolumn{2}{|c|}{ Térreo } & \multicolumn{2}{|c|}{$1^{\circ}$ pavimento } & \multicolumn{2}{|c|}{$2^{\circ}$ pavimento } & \multicolumn{2}{|c|}{$3^{\circ}$ pavimento } & \multicolumn{2}{|c|}{$4^{\circ}$ pavimento } & \multicolumn{2}{|c|}{$5^{\circ}$ pavimento } \\
\hline & @ & $\%$ & @ & $\%$ & @ & $\%$ & @ & $\%$ & @ & $\%$ & @ & $\%$ \\
\hline desaprumo & & - & & - & & - & & - & & - & & - \\
\hline torção da fôrma & & - & & - & & - & & - & & - & & - \\
\hline junta de concretagem & & - & & - & & - & & - & & - & & - \\
\hline falta de limpeza das formas & 3 & 20,00 & 4 & 26,67 & 7 & 46,67 & 3 & 20,00 & 6 & 40,00 & 11 & 73,33 \\
\hline falta de estanqueidade & 2 & 13,33 & 2 & 13,33 & 4 & 26,67 & 1 & 6,67 & 1 & 6,67 & 6 & 40,00 \\
\hline falta de limpeza nos elementos estruturais & & - & & - & & - & & - & & - & & - \\
\hline disgregação & & - & & - & & - & & - & & - & & - \\
\hline bicheiras & & - & 1 & 6,67 & & - & 2 & 13,33 & 11 & 73,33 & 2 & 13,33 \\
\hline segregação do concreto & & - & & - & 3 & 20,00 & 2 & 13,33 & & - & 4 & 26,67 \\
\hline falta de cobrimento de proteção das armaduras & 3 & 20,00 & 7 & 46,67 & 5 & 33,33 & 1 & 6,67 & 2 & 13,33 & 3 & 20,00 \\
\hline efeito parede & 2 & 13,33 & 7 & 46,67 & 7 & 46,67 & 1 & 6,67 & 2 & 13,33 & 2 & 13,33 \\
\hline falta de alinhamento horizontal ou vertical & & - & & - & & - & & - & 1 & 6,67 & & - \\
\hline carbonatação na superfície do concreto & & - & 1 & 6,67 & & - & & - & & - & & - \\
\hline manchas de corrosão ou armadura corroída & & - & 1 & 6,67 & & - & & - & 4 & 26,67 & 2 & 13,33 \\
\hline fissuras de retração & & - & & - & & - & & - & & - & & - \\
\hline fissuras inclinadas & & - & 2 & 13,33 & & - & & - & & - & & - \\
\hline fissuras em tubulação & & - & & - & & - & & - & & - & & - \\
\hline fissuras verticais & & - & & - & & - & & - & & - & & - \\
\hline deformação das fôrmas & & - & 1 & 6,67 & & - & 2 & 13,33 & & - & 1 & 6,67 \\
\hline reparo nos el. estrut. devido segregaçōes & & - & & - & & - & & - & & - & & - \\
\hline lixiviaçăo & & - & 2 & 13,33 & & - & & - & & - & & - \\
\hline eflorescências & & - & 2 & 13,33 & & - & & - & & - & & - \\
\hline falta de vibração & & - & & - & & - & & - & & - & & - \\
\hline desagregação do concreto & & - & & - & & - & & - & & - & & - \\
\hline
\end{tabular}


Elemento estrutural - VIGA

Número de elementos estruturais (viga) por pavimento $=49$

@ = número de manifestaçőes patológicas por pavimento

$\%=$ porcentagem de manifestações patológicas por pavimento

\begin{tabular}{|c|c|c|c|c|c|c|c|c|c|c|c|c|}
\hline \multirow{2}{*}{$\begin{array}{l}\text { PAVIMENTO } \\
\text { Tipo de manifestação patológica observada }\end{array}$} & \multicolumn{2}{|c|}{ Térreo } & \multicolumn{2}{|c|}{$1^{\circ}$ pavimento } & \multicolumn{2}{|c|}{$2^{\circ}$ pavimento } & \multicolumn{2}{|c|}{$3^{\circ}$ pavimento } & \multicolumn{2}{|c|}{$4^{\circ}$ pavimento } & \multicolumn{2}{|c|}{$5^{\circ}$ pavimento } \\
\hline & (a) & $\%$ & @ & $\%$ & @ & $\%$ & @ & $\%$ & @ & $\%$ & @ & $\%$ \\
\hline desaprumo & & - & & - & & - & & - & & - & & - \\
\hline torção da fôrma & & - & & - & & - & & - & 1 & 2,04 & & - \\
\hline junta de concretagem & & - & 2 & 4,08 & 1 & 2,04 & & - & 1 & 2,04 & & - \\
\hline falta de limpeza das fôrmas & 10 & 20,41 & 14 & 28,57 & 12 & 24,49 & 11 & 22,45 & 8 & 16,33 & 5 & 10,20 \\
\hline falta de estanqueidade das fôrmas & 12 & 24,49 & 15 & 30,61 & 15 & 30,61 & 13 & 26,53 & 16 & 32,65 & 17 & 34,69 \\
\hline falta de limpeza nos elementos estruturais & & - & & - & & - & & - & & - & & - \\
\hline disgregaçăo & & - & 1 & 2,04 & & - & 1 & 2,04 & & - & 2 & 4,08 \\
\hline bicheiras & & - & 2 & 4,08 & & - & & - & & - & & - \\
\hline segregação do concreto & 22 & 44,90 & 17 & 34,69 & 35 & 71,43 & 31 & 63,27 & 33 & 67,35 & 28 & 57,14 \\
\hline falta de cobrimento de proteção das armaduras & 32 & 65,31 & 37 & 75,51 & 34 & 69,39 & 26 & 53,06 & 36 & 73,47 & 39 & 79,59 \\
\hline efeito parede & & - & & - & & - & & - & & - & & - \\
\hline falta de alinhamento horizontal ou vertical & 2 & 4,08 & 2 & 4,08 & 1 & 2,04 & 4 & 8,16 & 3 & 6,12 & 4 & 8,16 \\
\hline carbonatação na superficie do concreto & & - & & - & & - & & - & & - & & - \\
\hline manchas de corrosão ou armadura corroída & 3 & 6,12 & 4 & 8,16 & 5 & 10,20 & 12 & 24,49 & 10 & 20,41 & 21 & 42,86 \\
\hline fissuras de retração & & - & & - & & - & 4 & 8,16 & 14 & 28,57 & & - \\
\hline fissuras inclinadas & & - & & - & & - & & - & & - & & - \\
\hline fissuras em tubulação & 2 & 4,08 & 3 & 6,12 & 1 & 2,04 & 7 & 14,29 & 6 & 12,24 & 1 & 2,04 \\
\hline fissuras verticais & & - & 1 & 2,04 & & - & 3 & 6,12 & 15 & 30,61 & & - \\
\hline deformação das fôrmas & & - & 1 & 2,04 & 1 & 2,04 & 7 & 14,29 & 2 & 4,08 & 1 & 2,04 \\
\hline reparo nos el. estrut. devido segregaçōes & & - & & - & & - & & - & & - & & - \\
\hline lixiviação & & - & & - & & - & & - & & - & & - \\
\hline eflorescências & & - & 1 & 2,04 & & - & & - & & - & & - \\
\hline falta de vibração & & - & & - & & - & & - & & - & & - \\
\hline desagregação do concreto & & - & & - & & - & & - & & - & & - \\
\hline
\end{tabular}




\section{Elemento estrutural - PILAR}

Número de elementos estruturais (pilar) por pavimento $=37$

@ = número de manifestações patológicas por pavimento

$\%=$ porcentagem de manifestações patológicas por pavimento

\begin{tabular}{|c|c|c|c|c|c|c|c|c|c|c|c|c|}
\hline PAVIMENTO & & rreo & $1^{\circ} \mathrm{p}$ & Ivimento & $2^{\circ} \mathrm{p}$ & vimento & $3^{\circ} \mathrm{p}$ & vimento & $4^{\circ} \mathrm{p}$ & vimento & $5^{\circ} \mathrm{pe}$ & avimento \\
\hline Tipo de manifestação patológica observada & @ & $\%$ & @ & $\%$ & @ & $\%$ & @ & $\%$ & @ & $\%$ & @ & $\%$ \\
\hline desaprumo & & - & & - & & - & & - & & - & & - \\
\hline torção da fôrma & & - & & - & & - & & - & & - & & - \\
\hline junta de concretagem & & - & & - & & - & & - & & - & & - \\
\hline falta de limpeza das fôrmas & & - & & - & & - & & - & & - & & - \\
\hline falta de estanqueidade das fôrmas & & - & & - & & - & & - & & - & & - \\
\hline falta de limpeza elementos estruturais & & - & & - & & - & & - & & - & & - \\
\hline disgregação & & - & & - & & - & & - & & - & 1 & - \\
\hline bicheiras & & - & & - & & - & & - & & - & & - \\
\hline segregação do concreto & & - & 4 & 10,81 & & - & & - & 5 & 13,51 & 3 & 8,11 \\
\hline falta de cobrimento de proteção das armaduras & 27 & 72,97 & 30 & 81,08 & 28 & 75,68 & 26 & 70,27 & 33 & 89,19 & 32 & 86,49 \\
\hline efeito parede & & - & & - & & - & & - & 2 & 5,41 & & - \\
\hline falta de alinhamento horizontal ou vertical & & - & & - & & - & & - & 1 & 2,70 & 1 & 2,70 \\
\hline carbonatação na superficie do concreto & & - & & - & & - & & - & & - & & - \\
\hline manchas de corrosão ou armadura corroída & & - & & - & & - & & - & & - & & - \\
\hline fissuras de retração & & - & & - & & - & & - & 1 & 2,70 & & - \\
\hline fissuras inclinadas & & - & & - & & - & & - & & - & 1 & 2,70 \\
\hline fissuras em tubulação & & - & & - & & - & & - & & - & & - \\
\hline fissuras verticais & & - & & - & & - & & - & & - & & - \\
\hline deformação das fôrmas & & - & & - & & - & & - & & - & & - \\
\hline reparo nos el. estrut. devido segregações & & - & & - & & - & & - & & - & 2 & 5,41 \\
\hline lixiviaçăo & & - & & - & & - & & - & & - & & - \\
\hline eflorescências & & - & & - & & - & & - & & - & & - \\
\hline falta de vibração & & - & & - & & - & & - & & - & & - \\
\hline desagregação do concreto & & - & & - & & - & & - & & - & & - \\
\hline
\end{tabular}


Elemento estrutural - PAREDE

Número de elementos estruturais (parede) por pavimento $=2$

$@$ = número de manifestaçōes patológicas por pavimento

$\%$ = porcentagem de manifestaçōes patológicas por pavimento

\begin{tabular}{|c|c|c|c|c|c|c|c|c|c|c|c|c|}
\hline \multirow{2}{*}{$\begin{array}{l}\text { PAVIMENTO } \\
\text { Tipo de manifestação patológica observada }\end{array}$} & \multicolumn{2}{|c|}{ Térreo } & \multicolumn{2}{|c|}{$1^{\circ}$ pavimento } & \multicolumn{2}{|c|}{$2^{\circ}$ pavimento } & \multicolumn{2}{|c|}{$3^{\circ}$ pavimento } & \multicolumn{2}{|c|}{$4^{\circ}$ pavimento } & \multicolumn{2}{|c|}{$5^{\circ}$ pavimento } \\
\hline & @ & $\%$ & $@$ & $\%$ & @ & $\%$ & @ & $\%$ & @ & $\%$ & @ & $\%$ \\
\hline desaprumo & & - & & - & & - & & - & & - & & - \\
\hline torção da fôrma & & - & & - & & - & & - & & - & & - \\
\hline junta de concretagem & & - & & - & & - & & - & & - & & - \\
\hline falta de limpeza das formas & & - & & - & & - & & - & & - & & - \\
\hline falta de estanqueidade & & - & & - & & - & & - & & - & & - \\
\hline falta de limpeza nos elementos estruturais & & - & & - & & - & & - & & - & & - \\
\hline disgregação & & - & & - & & - & & - & & - & & - \\
\hline bicheiras & & - & & - & & - & & - & 1 & 50,00 & 2 & 100,00 \\
\hline segregaçāo & 1 & 50,00 & 2 & 100,00 & 1 & 50,00 & 2 & 100,00 & 2 & 100,00 & 2 & 100,00 \\
\hline falta de cobrimento & & - & & - & & - & & - & & - & 2 & 100,00 \\
\hline efeito parede & & - & & - & & - & & - & & - & & - \\
\hline falta de alinhamento $\mathrm{h} / \mathrm{v}$ & & - & & - & 2 & 100,00 & & - & 1 & 50,00 & & - \\
\hline carbonatação & & - & & - & & - & & - & & - & & - \\
\hline armadura corroída & & - & & - & & - & & - & & - & & - \\
\hline fissuras de retração & & - & & - & & - & & - & & - & & - \\
\hline fissuras inclinadas & & - & & - & & - & & - & & - & & - \\
\hline fissuras em tubulação & & - & & - & & - & & - & & - & & - \\
\hline fissuras verticais & & - & & - & & - & & - & & - & & - \\
\hline abertura de fôrmas & & - & & - & & - & & - & & - & 1 & 50,00 \\
\hline reparos nos e.e devido segregações & & - & & - & & - & & - & & - & & - \\
\hline lixiviação & & - & & - & & - & & - & & - & & - \\
\hline eflorescências & & - & & - & & - & & - & & - & & - \\
\hline falta de vibração & & - & & - & & - & & - & & - & & - \\
\hline desagregação & & - & & - & & - & & - & & - & & - \\
\hline
\end{tabular}


ANEXO B - Tabelas quantitativas das ocorrências de cada elemento estrutural do Edifício B 


\section{Elemento estrutural - LAJE}

Número de elementos estruturais (laje) por pavimento $=11$

@ = número de manifestações patológicas por pavimento

$\%$ = porcentagem de manifestações patológicas por pavimento

\begin{tabular}{|c|c|c|c|c|c|c|c|c|c|c|c|c|c|c|}
\hline PAVIMENTO & & érreo & & breloja & $1^{\circ} \mathrm{p}$ & ivimento & $2^{\circ} p$ & vimento & $3^{\circ} \mathrm{p}$ & vimento & $4^{\circ} \mathrm{F}$ & vimento & $5^{\circ} \mathrm{p}$ & vimento \\
\hline Tipo de manifestação patológica observada & @ & $\%$ & @ & $\%$ & @ & $\%$ & @ & $\%$ & @ & $\%$ & @ & $\%$ & @ & $\%$ \\
\hline desaprumo & & - & & - & & - & & - & & - & & - & & - \\
\hline torção da fôrma & & - & & - & & - & & - & & - & & - & & - \\
\hline junta de concretagem & & - & & - & & - & & - & & - & & - & & - \\
\hline falta de limpeza das fôrmas & 11 & 100,00 & 13 & 118,18 & 2 & 18,18 & 2 & 18,18 & & - & 3 & 27,27 & 10 & 90,91 \\
\hline falta de estanqueidade & 3 & 27,27 & 1 & 9,09 & 3 & 27,27 & 4 & 36,36 & 2 & 18,18 & 5 & 45,45 & 5 & 45,45 \\
\hline falta de limpeza elementos estruturais & & - & 1 & 9,09 & & - & & - & & - & 2 & 18,18 & & - \\
\hline disgregação & & - & & - & & - & & - & & - & & - & & - \\
\hline bicheiras & & - & & - & 1 & 9,09 & & - & & - & & - & & - \\
\hline segregação do concreto & 1 & 9,09 & & - & & - & & - & 2 & 18,18 & & - & 1 & 9,09 \\
\hline falta de cobrimento de proteção das armaduras & 1 & 9,09 & & - & 2 & 18,18 & 2 & 18,18 & & - & & - & & - \\
\hline efeito parede & 3 & 27,27 & 6 & 54,55 & 5 & 45,45 & 8 & 72,73 & 7 & 63,64 & 2 & 18,18 & 2 & 18,18 \\
\hline falta de alinhamento horizontal ou vertical & & - & & - & 2 & 18,18 & & - & 3 & 27,27 & 4 & 36,36 & 5 & 45,45 \\
\hline carbonatação na superfície do concreto & & - & & - & & - & & - & & - & & - & & - \\
\hline manchas de corrosão ou armadura corroida & & - & & - & & - & & - & 1 & 9,09 & 1 & 9,09 & 1 & 9,09 \\
\hline fissuras de retração & & - & & - & & - & & - & & - & & - & & - \\
\hline fissuras inclinadas & & - & & - & 1 & 9,09 & 3 & 27,27 & 2 & 18,18 & 5 & 45,45 & & - \\
\hline fissuras em tubulação & & - & & - & & - & & - & & - & & - & & - \\
\hline fissuras verticais & & - & & - & & - & & - & & - & & - & & - \\
\hline deformação das fôrmas & & - & 1 & 9,09 & & - & & - & & - & & - & & - \\
\hline reparo nos el. estrut. devido segregaçōes & & - & & - & & - & & - & & - & & - & & - \\
\hline lixiviaçăo & & - & & - & 1 & 9,09 & 3 & 27,27 & 2 & 18,18 & 5 & 45,45 & & - \\
\hline eflorescências & & - & & - & 1 & 9,09 & 3 & 27,27 & 2 & 18,18 & 5 & 45,45 & & - \\
\hline falta de vibração & & - & & - & 2 & 18,18 & & - & & - & & - & 1 & 9,09 \\
\hline desagregação do concreto & & - & & - & & - & & - & & - & & - & & - \\
\hline
\end{tabular}




\section{Elemento estrutural - LAJE}

Número de elementos estruturais ( laje ) por pavimento $=5$

@ = número de manifestações patológicas por pavimento

$\%=$ porcentagem de manifestações patológicas por pavimento

\begin{tabular}{|c|c|c|c|c|c|c|c|c|c|c|c|c|c|c|}
\hline \multirow{2}{*}{$\begin{array}{l}\text { PAVIMENTO } \\
\text { Tipo de manifestação patológica observada }\end{array}$} & \multicolumn{2}{|c|}{$6^{\circ}$ pavimento } & \multicolumn{2}{|c|}{$7^{0}$ pavimento } & \multicolumn{2}{|c|}{$8^{\circ}$ pavimento } & \multicolumn{2}{|c|}{$9^{\circ}$ pavimento } & \multicolumn{2}{|c|}{$10^{\circ}$ pavimento } & \multicolumn{2}{|c|}{$11^{\circ}$ pavimento } & \multicolumn{2}{|c|}{$12^{\circ}$ pavimento } \\
\hline & @ & $\%$ & @ & $\%$ & @ & $\%$ & @ & $\%$ & @ & $\%$ & @ & $\%$ & @ & $\%$ \\
\hline desaprumo & & - & & - & & - & & - & & - & & - & & - \\
\hline torção da fôrma & & - & & - & & - & & - & & - & & - & & - \\
\hline junta de concretagem & & - & 1 & 9,09 & & - & 1 & 9,09 & & - & & - & & - \\
\hline falta de limpeza das fôrmas & & - & 5 & 45,45 & & - & & - & 5 & 45,45 & & - & & - \\
\hline falta de estanqueidade das fôrmas & 2 & 18,18 & 4 & 36,36 & 5 & 45,45 & 6 & 54,55 & 3 & 27,27 & 10 & 90,91 & 11 & 100,00 \\
\hline falta de limpeza elementos estruturais & 1 & 9,09 & 6 & 54,55 & 4 & 36,36 & & - & & - & & - & 4 & 36,36 \\
\hline disgregação & & - & & - & & - & & - & & - & & - & & - \\
\hline bicheiras & & - & & - & & - & & - & & - & & - & & - \\
\hline segregação do concreto & 2 & 18,18 & 1 & 9,09 & & - & 1 & 9,09 & & - & & - & & - \\
\hline falta de cobrimento de proteção das armaduras & 2 & 18,18 & 2 & 18,18 & & - & 1 & 9,09 & 2 & 18,18 & & - & & - \\
\hline efeito parede & 6 & 54,55 & 8 & 72,73 & 3 & 27,27 & 9 & 81,82 & 5 & 45,45 & 8 & 72,73 & 9 & 81,82 \\
\hline falta de alinhamento horizontal ou vertical & 1 & 9,09 & 4 & 36,36 & 5 & 45,45 & 1 & 9,09 & 3 & 27,27 & 1 & 9,09 & & - \\
\hline carbonatação na superfície de concreto & & - & & - & & - & & - & & - & & - & & - \\
\hline manchas de corrosão ou armadura corroída & 1 & 9,09 & 1 & 9,09 & & - & & - & 1 & 9,09 & & - & & - \\
\hline fissuras de retração & & - & & - & & - & & - & & - & & - & & - \\
\hline fissuras inclinadas & & - & 2 & 18,18 & 3 & 27,27 & & - & 4 & 36,36 & 6 & 54,55 & 3 & 27,27 \\
\hline fissuras em tubulação & & - & & - & & - & & - & & - & & - & & - \\
\hline fissuras verticais & & - & & - & & - & & - & & - & & - & & - \\
\hline deformação das fôrmas & & - & 1 & 9,09 & & - & & - & 1 & 9,09 & & - & 2 & 18,18 \\
\hline reparo nos el. estrut. devido segregaçōes & & - & & - & & - & & - & & - & & - & & - \\
\hline lixiviação & & - & 2 & 18,18 & 3 & 27,27 & & - & 4 & 36,36 & 6 & 54,55 & 3 & 27,27 \\
\hline eflorescências & & - & 2 & 18,18 & 3 & 27,27 & & - & 4 & 36,36 & 6 & 54,55 & 3 & 27,27 \\
\hline falta de vibração & & - & & - & & - & 3 & 27,27 & & - & 1 & 9,09 & & - \\
\hline desagregação do concreto & & - & & - & & - & & - & & - & & - & & - \\
\hline
\end{tabular}




\section{Elemento estrutural - VIGA}

Número de elementos estruturais (viga) por pavimento $=30$

Q = número de manifestaçőes patológicas por pavimento

$\%$ = porcentagem de manifestações patológicas por pavimento

\begin{tabular}{|c|c|c|c|c|c|c|c|c|c|c|c|c|c|c|}
\hline PAVIMENTO & & érreo & & breloja & $\overline{1^{\circ} \mathrm{p}}$ & vimento & $2^{\circ} \mathrm{pe}$ & nento & $\overline{3^{\circ} \mathrm{pe}}$ & nento & $\overline{4^{0} \mathrm{p}}$ & vimento & $\overline{5^{\circ} \mathrm{pe}}$ & vimento \\
\hline Tipo de manifestação patológica observada & @ & $\%$ & @ & $\%$ & @ & $\%$ & @ & $\%$ & @ & $\%$ & @ & $\%$ & @ & $\%$ \\
\hline desaprumo & & - & & - & & - & $\mathrm{R}$ & & $\mathrm{R}$ & & & - & & - \\
\hline torção da fôrma & & - & & - & & - & $\mathrm{R}$ & & $\mathrm{R}$ & & & - & 4 & 13,33 \\
\hline junta de concretagem & 1 & 3,33 & 3 & 10,00 & 1 & 3,33 & $\mathrm{R}$ & & $\mathrm{R}$ & & 1 & 3,33 & 2 & 6,67 \\
\hline falta de limpeza das formas & & - & 4 & 13,33 & 1 & 3,33 & $\mathrm{R}$ & & $\mathrm{R}$ & & 3 & 10,00 & 1 & 3,33 \\
\hline falta de estanqueidade das fôrmas & 2 & 6,67 & 3 & 10,00 & 5 & 16,67 & $\mathrm{R}$ & & $\mathrm{R}$ & & 6 & 20,00 & 4 & 13,33 \\
\hline falta de cobrimento de proteção das armaduras & & - & 2 & 6,67 & 1 & 3,33 & $\mathrm{R}$ & & $\mathrm{R}$ & & & - & & - \\
\hline disgregação & & - & 1 & 3,33 & & - & $\mathrm{R}$ & & $\mathrm{R}$ & & & - & & - \\
\hline bicheiras & & - & 2 & 6,67 & 2 & 6,67 & $\mathrm{R}$ & & $\mathrm{R}$ & & 3 & 10,00 & & - \\
\hline segregação do concreto & 6 & 20,00 & 5 & 16,67 & 7 & 23,33 & $\mathrm{R}$ & & $\mathrm{R}$ & & 11 & 36,67 & 15 & 50,00 \\
\hline falta de cobrimento de proteção das armaduras & 1 & 3,33 & 9 & 30,00 & 8 & 26,67 & $\mathrm{R}$ & & $\mathrm{R}$ & & 5 & 16,67 & 14 & 46,67 \\
\hline efeito parede & & - & & - & & - & $\mathrm{R}$ & & $\mathrm{R}$ & & & - & & - \\
\hline falta de alinhamento horizontal ou vertical & & - & & - & 5 & 16,67 & $\mathrm{R}$ & & $\mathrm{R}$ & & 2 & 6,67 & 4 & 13,33 \\
\hline carbonatação na superficie do concreto & & - & & - & & - & $\mathrm{R}$ & & $\mathrm{R}$ & & & - & & - \\
\hline manchas de corrosão ou armadura corroída & & - & 3 & 10,00 & 1 & 3,33 & $\mathrm{R}$ & & $\mathrm{R}$ & & & - & & - \\
\hline fissuras de retraçāo & & - & & - & & - & $\mathrm{R}$ & & $\mathrm{R}$ & & & - & & - \\
\hline fissuras inclinadas & & - & & - & & - & $\mathrm{R}$ & & $\mathrm{R}$ & & & - & & - \\
\hline fissuras em tubulação & & - & & - & 3 & 10,00 & $\mathrm{R}$ & & $\mathrm{R}$ & & & - & & - \\
\hline fissuras verticais & & - & & - & 5 & 16,67 & $\mathrm{R}$ & & $\mathrm{R}$ & & & - & & - \\
\hline deformação das fôrmas & 2 & 6,67 & 3 & 10,00 & 2 & 6,67 & $\mathrm{R}$ & & $\mathrm{R}$ & & 5 & 16,67 & 7 & 23,33 \\
\hline reparo nos el. estrut. devido segregações & 2 & 6,67 & 2 & 6,67 & 5 & 16,67 & $\mathrm{R}$ & & $\mathrm{R}$ & & & - & & - \\
\hline lixiviação & & - & & - & & - & $\mathrm{R}$ & & $\mathrm{R}$ & & 1 & 3,33 & & - \\
\hline eflorescências & & - & & - & & - & $\mathrm{R}$ & & $\mathrm{R}$ & & 1 & 3,33 & & - \\
\hline falta de vibração & & - & & - & & - & $\mathrm{R}$ & & $\mathrm{R}$ & & & - & & - \\
\hline desagregação do concreto & & - & & - & & - & $\mathrm{R}$ & & $\mathrm{R}$ & & & - & & - \\
\hline
\end{tabular}

Obs: $\mathbf{R}=$ Rebocado 


\section{Elemento estrutural - VIGA}

Número de elementos estruturais ( viga ) por pavimento $=30$

@ = número de manifestações patológicas por pavimento

$\%=$ porcentagem de manifestações patológicas por pavimento

\begin{tabular}{|c|c|c|c|c|c|c|c|c|c|c|c|c|c|c|}
\hline PAVIMENTO & $6^{\circ} \mathrm{p}$ & ivimento & $7^{\circ} \mathrm{p}$ & vimento & $8^{\circ} \mathrm{p}$ & vimento & $9^{\circ} \mathrm{p}$ & vimento & $10^{\circ} \mathrm{F}$ & avimentc & $11^{\circ} \mathrm{p}$ & aviment & $12^{\circ} \mathrm{F}$ & avimento \\
\hline Tipo de manifestação patológica observada & @ & $\%$ & @ & $\%$ & @ & $\%$ & @ & $\%$ & @ & $\%$ & @ & $\%$ & @ & $\%$ \\
\hline desaprumo & & - & & - & & - & & - & & - & & - & & - \\
\hline torção da fôrma & & - & 2 & 6,67 & 1 & 3,33 & 4 & 13,33 & 2 & 6,67 & 1 & 3,33 & & - \\
\hline junta de concretagem & 1 & 3,33 & 1 & 3,33 & & - & & - & 1 & 3,33 & 1 & 3,33 & 1 & 3,33 \\
\hline falta de limpeza das fôrmas & & - & & - & & - & & - & & - & & - & & - \\
\hline falta de estanqueidade & 3 & 10,00 & 2 & 6,67 & 3 & 10,00 & 2 & 6,67 & 1 & 3,33 & 2 & 6,67 & 1 & 3,33 \\
\hline falta de limpeza elementos estruturais & & - & 1 & 3,33 & 2 & 6,67 & 1 & 3,33 & & - & & - & 8 & 26,67 \\
\hline disgregação & & - & & - & & - & & - & & - & & - & & - \\
\hline bicheiras & 1 & 3,33 & 1 & 3,33 & 3 & 10,00 & 7 & 23,33 & 1 & 3,33 & & - & & - \\
\hline segregação & 8 & 26,67 & 13 & 43,33 & 26 & 86,67 & 23 & 76,67 & 7 & 23,33 & 6 & 20,00 & 9 & 30,00 \\
\hline falta de cobrimento & 3 & 10,00 & 5 & 16,67 & 4 & 13,33 & 7 & 23,33 & 4 & 13,33 & 3 & 10,00 & 1 & 3,33 \\
\hline efeito parede & & - & & - & & - & & - & & - & & - & & - \\
\hline falta de alinhamento $\mathrm{h} / \mathrm{v}$ & 1 & 3,33 & 2 & 6,67 & 5 & 16,67 & 9 & 30,00 & 10 & 33,33 & 6 & 20,00 & 6 & 20,00 \\
\hline carbonatação & & - & & - & & - & & - & & - & & - & & - \\
\hline armadura corroída & 1 & 3,33 & 2 & 6,67 & 2 & 6,67 & 7 & 23,33 & 5 & 16,67 & & - & & - \\
\hline fissuras de retração & & - & & - & & - & & - & & - & & - & 2 & 6,67 \\
\hline fissuras inclinadas & & - & & - & & - & & - & & - & & - & & - \\
\hline fissuras em tubulação & 1 & 3,33 & & - & 4 & 13,33 & 6 & 20,00 & 2 & 6,67 & 7 & 23,33 & 2 & 6,67 \\
\hline fissuras verticais & 1 & 3,33 & 2 & 6,67 & 4 & 13,33 & 3 & 10,00 & 4 & 13,33 & 4 & 13,33 & 1 & 3,33 \\
\hline deformação das fôrmas & 2 & 6,67 & 1 & 3,33 & 3 & 10,00 & 2 & 6,67 & 3 & 10,00 & 4 & 13,33 & 3 & 10,00 \\
\hline reparos nos e.e devido segregaçōes & 1 & 3,33 & 2 & 6,67 & 3 & 10,00 & & - & & - & 5 & 16,67 & & - \\
\hline lixiviação & & - & & - & 2 & 6,67 & & - & & - & & - & & - \\
\hline eflorescências & & - & & - & 2 & 6,67 & & - & & - & & - & & - \\
\hline falta de vibração & & - & & - & & - & & - & & - & & - & & - \\
\hline desagregação & & - & & - & & - & & - & & - & & - & & - \\
\hline
\end{tabular}




\section{Elemento estrutural - PILAR}

Número de elementos estruturais (pilar) por pavimento $=20$

@ = número de manifestações patológicas por pavimento

$\%$ = porcentagem de manifestações patológicas por pavimento

\begin{tabular}{|c|c|c|c|c|c|c|c|c|c|c|c|c|c|c|}
\hline \multirow{2}{*}{$\begin{array}{l}\text { PAVIMENTO } \\
\text { Tipo de manifestação patológica observada }\end{array}$} & \multicolumn{2}{|c|}{ Térreo } & \multicolumn{2}{|c|}{ Sobreloja } & \multicolumn{2}{|c|}{$1^{\circ}$ pavimento } & \multicolumn{2}{|c|}{$2^{\circ}$ pavimento } & \multicolumn{2}{|c|}{$3^{\circ}$ pavimento } & \multicolumn{2}{|c|}{$4^{\circ}$ pavimento } & \multicolumn{2}{|c|}{$5^{\circ}$ pavimento } \\
\hline & @ & $\%$ & $@$ & $\%$ & @ & $\%$ & @ & $\%$ & @ & $\%$ & @ & $\%$ & @ & $\%$ \\
\hline desaprumo & & - & 2 & 10,00 & 1 & 5,00 & $\mathrm{R}$ & & 2 & 10,00 & 4 & 20,00 & 1 & 5,00 \\
\hline torção da fôrma & & - & 1 & 5,00 & & - & $\mathbf{R}$ & & & - & & - & 3 & 15,00 \\
\hline junta de concretagem & & - & & - & 1 & 5,00 & $\mathbf{R}$ & & & - & & - & & - \\
\hline falta de limpeza das fôrmas & & - & & - & & - & $\mathbf{R}$ & & & - & & - & & - \\
\hline falta de estanqueidade das fôrmas & & - & & - & & - & $\mathrm{R}$ & & & - & & - & & - \\
\hline falta de limpeza elementos estruturais & & - & 1 & 5,00 & & - & $\mathbf{R}$ & & & - & 1 & 5,00 & & - \\
\hline disgregação & & - & & - & & - & $\mathrm{R}$ & & & - & 1 & 5,00 & & - \\
\hline bicheiras & & - & 1 & 5,00 & & - & $\mathrm{R}$ & & 2 & 10,00 & 1 & 5,00 & & - \\
\hline segregaçäo do concreto & 8 & 40,00 & 8 & 40,00 & 8 & 40,00 & $\mathrm{R}$ & & 3 & 15,00 & 8 & 40,00 & 8 & 40,00 \\
\hline falta de cobrimento de proteção das armaduras & & - & 1 & 5,00 & 1 & 5,00 & $\mathrm{R}$ & & & - & 2 & 10,00 & & - \\
\hline efeito parede & & - & & - & & - & $\mathbf{R}$ & & & - & & - & & - \\
\hline falta de alinhamento horizontal ou vertical & & - & & - & & - & $\mathbf{R}$ & & & - & & - & & - \\
\hline carbonatação na superfície do concreto & & - & & - & & - & $\mathrm{R}$ & & & - & & - & & - \\
\hline manchas de corrosão ou armadura corroída & & - & & - & & - & $\mathrm{R}$ & & & - & & - & & - \\
\hline fissuras de retração & & - & & - & & - & $\mathrm{R}$ & & & - & & - & & - \\
\hline fissuras inclinadas & & - & & - & & - & $\mathbf{R}$ & & & - & & - & & - \\
\hline fissuras em tubulação & & - & & - & & - & $\mathrm{R}$ & & & - & & - & & - \\
\hline fissuras verticais & & - & & - & & - & $\mathrm{R}$ & & & - & & - & & - \\
\hline deformação das fôrmas & 5 & 25,00 & 7 & 35,00 & 5 & 25,00 & $\mathrm{R}$ & & 3 & 15,00 & 6 & 30,00 & 1 & 5,00 \\
\hline reparo nos el. estrut. devido segregaçōes & 3 & 15,00 & 5 & 25,00 & 6 & 30,00 & $\mathrm{R}$ & & 2 & 10,00 & 4 & 20,00 & 2 & 10,00 \\
\hline lixiviação & & - & & - & & - & $\mathbf{R}$ & & & - & & - & & - \\
\hline eflorescências & & - & & - & & - & $\mathrm{R}$ & & & - & & - & & - \\
\hline falta de vibração & & - & & - & & - & $\mathrm{R}$ & & & - & & - & & - \\
\hline desagregação do concreto & & - & & - & & - & $\mathrm{R}$ & & & - & & - & & - \\
\hline
\end{tabular}

Obs : $R=$ Rebocado 
Número de elementos estruturais ( pilar ) por pavimento $=20$

@ = número de manifestações patológicas por pavimento

$\%=$ porcentagem de manifestações patológicas por pavimento

\begin{tabular}{|c|c|c|c|c|c|c|c|c|c|c|c|c|c|c|}
\hline PAVIMENTO & $6^{\circ} \mathrm{p}$ & Ivimento & $7^{0} \mathrm{p}$ & mento & $8^{\circ} p$ & vimento & $9^{\circ} \mathrm{p}$ & vimento & $10^{\circ} \mathrm{r}$ & avimento & $11^{\circ} \mathrm{F}$ & avimento & $12^{\circ} \mathrm{p}$ & avimento \\
\hline Tipo de manifestação patológica observada & @ & $\%$ & @ & $\%$ & @ & $\%$ & @ & $\%$ & @ & $\%$ & @ & $\%$ & @ & $\%$ \\
\hline desaprumo & 3 & 15,00 & 2 & 10,00 & 2 & 10,00 & 3 & 15,00 & 3 & 15,00 & 3 & 15,00 & 1 & 5,00 \\
\hline torção da fôrma & & - & 1 & 5,00 & 2 & 10,00 & 1 & 5,00 & & - & & - & & - \\
\hline junta de concretagem & & - & & - & & - & & - & & - & & - & & - \\
\hline falta de limpeza das formas & & - & & - & & - & & - & & - & & - & 4 & 20,00 \\
\hline falta de estanqueidade das fôrmas & 1 & 5,00 & 4 & 20,00 & & - & 1 & 5,00 & 3 & 15,00 & & - & 2 & 10,00 \\
\hline falta de limpeza elementos estruturais & 1 & 5,00 & 1 & 5,00 & & - & & - & & - & & - & 1 & 5,00 \\
\hline disgregação & 1 & 5,00 & & - & & - & & - & & - & & - & & - \\
\hline bicheiras & & - & 3 & 15,00 & 2 & 10,00 & 2 & 10,00 & & - & & - & 1 & 5,00 \\
\hline segregação do concreto & 8 & 40,00 & 8 & 40,00 & 9 & 45,00 & 12 & 60,00 & 8 & 40,00 & 10 & 50,00 & 13 & 65,00 \\
\hline falta de cobrimento de proteção das armaduras & & - & & - & 1 & 5,00 & 3 & 15,00 & 5 & 25,00 & 2 & 10,00 & & - \\
\hline efeito parede & & - & & - & & - & & - & & - & & - & & - \\
\hline falta de alinhamento horizontal ou vertical & 1 & 5,00 & 1 & 5,00 & & - & 2 & 10,00 & 4 & 20,00 & 1 & 5,00 & & - \\
\hline carbonatação na superfície do concreto & & - & & - & & - & & - & & - & & - & & - \\
\hline manchas de corrosão ou armadura corroída & & - & & - & & - & 2 & 10,00 & 5 & 25,00 & 2 & 10,00 & & - \\
\hline fissuras de retração & & - & & - & & - & & - & & - & & - & & - \\
\hline fissuras inclinadas & & - & & - & & - & & - & & - & & - & & - \\
\hline fissuras em tubulação & & - & & - & & - & & - & & - & & - & & - \\
\hline fissuras verticais & & - & & - & & - & & - & & - & & - & & - \\
\hline deformação das fôrmas & 4 & 20,00 & 7 & 35,00 & 5 & 25,00 & 6 & 30,00 & 4 & 20,00 & 3 & 15,00 & 3 & 15,00 \\
\hline reparo nos el. estrut. devido segregaçōes & & - & & - & & - & & - & & - & & - & & - \\
\hline lixiviação & & - & & - & & - & & - & & - & & - & & - \\
\hline eflorescências & & - & & - & & - & & - & & - & & - & & - \\
\hline falta de vibração & & - & & - & & - & & - & & - & & - & & - \\
\hline desagregação do concreto & & - & & - & & - & & - & & - & & - & & - \\
\hline
\end{tabular}


Número de elementos estruturais (parede) por pavimento $=16$

@ = número de manifestações patológicas por pavimento

$\%=$ porcentagem de manifestaçöes patológicas por pavimento

\begin{tabular}{|c|c|c|c|c|c|c|c|c|c|c|c|c|c|c|}
\hline PAVIMENTO & & érreo & & breloja & $1^{\circ} \mathrm{p}$ & avimento & $2^{\circ} \mathrm{p}$ & vimento & $3^{\circ} \mathrm{pe}$ & nento & $4^{\circ} \mathrm{pa}$ & mento & $\overline{5^{\circ} \mathrm{pe}}$ & ivimento \\
\hline Tipo de manifestação patológica observada & @ & $\%$ & @ & $\%$ & @ & $\%$ & @ & $\%$ & (d) & $\%$ & Q & $\%$ & @ & $\%$ \\
\hline desaprumo & & - & 1 & 6,25 & & - & 1 & 6,25 & $\mathrm{R}$ & & $\mathbf{R}$ & & & - \\
\hline torção da fôrma & 1 & 6,25 & 3 & 18,75 & 1 & 6,25 & & - & $\mathrm{R}$ & & $\mathbf{R}$ & & & - \\
\hline junta de concretagem & & - & 2 & 12,50 & 5 & 31,25 & & - & $\mathrm{R}$ & & $\mathbf{R}$ & & & - \\
\hline falta de limpeza das fôrmas & & - & & - & & - & & - & $\mathrm{R}$ & & $\mathbf{R}$ & & & - \\
\hline falta de estanqueidade & 1 & 6,25 & 2 & 12,50 & 2 & 12,50 & 3 & 18,75 & $\mathrm{R}$ & & $\mathbf{R}$ & & 2 & 12,50 \\
\hline falta de limpeza elementos estruturais & & - & 1 & 6,25 & & - & & - & $\mathrm{R}$ & & $\mathbf{R}$ & & & - \\
\hline disgregação & & - & & - & & - & & - & $\mathrm{R}$ & & $\mathbf{R}$ & & & - \\
\hline bicheiras & 1 & 6,25 & & - & & - & 2 & 12,50 & $\mathrm{R}$ & & $\mathbf{R}$ & & & - \\
\hline segregaação & 5 & 31,25 & 6 & 37,50 & 1 & 6,25 & & - & $\mathbf{R}$ & & $\mathbf{R}$ & & 5 & 31,25 \\
\hline falta de cobrimento & & - & & - & & - & 1 & 6,25 & $\mathrm{R}$ & & $\mathbf{R}$ & & 1 & 6,25 \\
\hline efeito parede & & - & & - & & - & & - & $\mathbf{R}$ & & $\mathbf{R}$ & & & - \\
\hline falta de alinhamento $h / v$ & 2 & 12,50 & 1 & 6,25 & 3 & 18,75 & & - & $\mathrm{R}$ & & $\mathrm{R}$ & & 2 & 12,50 \\
\hline carbonatação & & - & & - & & - & & - & $\mathrm{R}$ & & $\mathrm{R}$ & & & - \\
\hline armadura corroída & & - & & - & & - & & - & $\mathrm{R}$ & & $\mathrm{R}$ & & 1 & 6,25 \\
\hline fissuras de retração & & - & & - & & - & & - & $\mathbf{R}$ & & $\mathrm{R}$ & & & - \\
\hline fissuras inclinadas & & - & & - & & - & & - & $\mathrm{R}$ & & $\mathrm{R}$ & & & - \\
\hline fissuras em tubulação & & - & & - & & - & & - & $\mathrm{R}$ & & $\mathrm{R}$ & & & - \\
\hline fissuras verticais & & - & & - & & - & & - & $\mathrm{R}$ & & $\mathrm{R}$ & & & - \\
\hline deformação das fôrmas & 2 & 12,50 & 1 & 6,25 & 3 & 18,75 & 1 & 6,25 & $\mathbf{R}$ & & $\mathbf{R}$ & & 2 & 12,50 \\
\hline reparos nos e.e devido segregações & 12 & 75,00 & 10 & 62,50 & 10 & 62,50 & 4 & 25,00 & $\mathbf{R}$ & & $\mathrm{R}$ & & 2 & 12,50 \\
\hline lixiviaçäo & & - & & - & & - & & - & $\mathrm{R}$ & & $\mathbf{R}$ & & & - \\
\hline eflorescências & & - & & - & & - & & - & $\mathrm{R}$ & & $\mathbf{R}$ & & & - \\
\hline falta de vibração & & - & & - & & - & & - & $\mathbf{R}$ & & $\mathbf{R}$ & & & - \\
\hline desagregação & & - & & - & & - & & - & $\mathbf{R}$ & & $\mathrm{R}$ & & & - \\
\hline
\end{tabular}

Obs : R= Rebocado 


\section{Elemento estrutural - PAREDE}

Número de elementos estruturais (parede) por pavimento $=16$

@ = número de manifestações patológicas por pavimento

$\%$ = porcentagem de manifestações patológicas por pavimento

\begin{tabular}{|c|c|c|c|c|c|c|c|c|c|c|c|c|c|c|}
\hline PAVIMENTO & $6^{\circ} \mathrm{p}$ & avimento & $7^{\circ} \mathrm{p}$ & vimento & $8^{\circ} \mathrm{pe}$ & ivimento & $9^{\circ} \mathrm{p}^{2}$ & vimento & $10^{\circ} \mathrm{F}$ & aviment & $\overline{11^{\circ} \mathrm{p}}$ & avimento & $\overline{12^{\circ} \mathrm{p}}$ & avimento \\
\hline Tipo de manifestação patológica observada & @ & $\%$ & @ & $\%$ & @ & $\%$ & (C) & $\%$ & @ & $\%$ & @ & $\%$ & @ & $\%$ \\
\hline desaprumo & 1 & 6,25 & & - & 1 & 6,25 & & - & & - & & - & & - \\
\hline torção da fôrma & & - & & - & & - & & - & & - & & - & & - \\
\hline junta de concretagem & & - & & - & & - & & - & 1 & 6,25 & & - & & - \\
\hline falta de limpeza das fôrmas & & - & 1 & 6,25 & & - & & - & & - & & - & 1 & 6,25 \\
\hline falta de estanqueidade das fôrmas & 4 & 25,00 & & - & 2 & 12,50 & & - & & - & 1 & 6,25 & & - \\
\hline falta de limpeza elementos estruturais & & - & 2 & 12,50 & & - & & - & & - & & - & 5 & 31,25 \\
\hline disgregação & 1 & 6,25 & & - & 1 & 6,25 & & - & & - & & - & & - \\
\hline bicheiras & 2 & 12,50 & 1 & 6,25 & & - & 1 & 6,25 & & - & 1 & 6,25 & & - \\
\hline segregação do concreto & 7 & 43,75 & 7 & 43,75 & 11 & 68,75 & 11 & 68,75 & 13 & 81,25 & 7 & 43,75 & 8 & 50,00 \\
\hline falta de cobrimento de proteção das armaduras & 1 & 6,25 & 2 & 12,50 & 4 & 25,00 & 3 & 18,75 & 2 & 12,50 & & - & 1 & 6,25 \\
\hline efeito parede & & - & & - & & - & & - & & - & & - & & - \\
\hline falta de alinhamento horizontal ou vertical & 1 & 6,25 & 2 & 12,50 & 2 & 12,50 & 1 & 6,25 & 1 & 6,25 & 3 & 18,75 & 1 & 6,25 \\
\hline carbonatação na superfície do concreto & & - & & - & & - & & - & & - & & - & & - \\
\hline manchas de corrosão ou armadura corroída & 1 & 6,25 & 2 & 12,50 & 3 & 18,75 & 4 & 25,00 & 2 & 12,50 & 2 & 12,50 & 1 & 6,25 \\
\hline fissuras de retração & & - & & - & & - & & - & & - & & - & & - \\
\hline fissuras inclinadas & & - & & - & & - & & - & & - & & - & & - \\
\hline fissuras em tubulação & & - & & - & & - & & - & & - & & - & & - \\
\hline fissuras verticais & & - & & - & & - & & - & & - & & - & & - \\
\hline deformação das fôrmas & 2 & 12,50 & 5 & 31,25 & 1 & 6,25 & 3 & 18,75 & & - & 3 & 18,75 & 4 & 25,00 \\
\hline reparo nos el. estrut. devido segregações & 2 & 12,50 & & - & 1 & 6,25 & & - & & - & & - & & - \\
\hline lixiviação & & - & & - & & - & & - & & - & & - & & - \\
\hline eflorescências & & - & & - & & - & & - & & - & & - & & - \\
\hline falta de vibração & & - & & - & & - & & - & & - & & - & & - \\
\hline desagregação do concreto & & - & & - & & - & & - & & - & & - & & - \\
\hline
\end{tabular}


ANEXO C - Tabelas quantitativas das ocorrências de cada elemento estrutural do Edifício C 


\section{Elemento estrutural - LAJE}

Número de elementos estruturais (laje) por pavimento $=19$

$@$ = número de manifestações patológicas por pavimento

$\%=$ porcentagem de manifestaçőes patológicas por pavimento

\begin{tabular}{|c|c|c|c|c|c|c|c|c|c|c|c|c|c|c|}
\hline PAVIMENTO & & érreo & $2^{\circ} \mathrm{p}$ & vimento & $3^{\circ} \mathrm{p}$ & imento & $4^{\circ} \mathrm{p}$ & vimento & $5^{\circ} \mathrm{p}$ & ivimento & $6^{\circ} \mathrm{F}$ & vimento & $7^{\circ} \mathrm{pe}$ & vimento \\
\hline Tipo de manifestação patológica observada & (C) & $\%$ & (Q) & $\%$ & @ & $\%$ & (Q) & $\%$ & (Q) & $\%$ & (C) & $\%$ & (1) & $\%$ \\
\hline desaprumo & & - & & - & & - & & - & & - & & - & & - \\
\hline torção da fôrma & & - & & - & & - & & - & & - & & - & & - \\
\hline junta de concretagem & & - & & - & & - & & - & & - & & - & & - \\
\hline falta de limpeza das fôrmas & 1 & 4,17 & 7 & 29,17 & & - & & - & & - & & - & 3 & 12,50 \\
\hline falta de estanqueidade das fôrmas & & - & 1 & 4,17 & 3 & 12,50 & 2 & 8,33 & 3 & 12,50 & 6 & 25,00 & 2 & 8,33 \\
\hline falta de limpeza elementos estruturais & & - & & - & & - & & - & & - & & - & & - \\
\hline disgregação & & - & & - & & - & & - & & - & & - & 1 & 4,17 \\
\hline bicheiras & & - & & - & 1 & 4,17 & & - & & - & & - & & - \\
\hline segregação do concreto & & - & & - & & - & & - & & - & & - & & - \\
\hline falta de cobrimento de proteção das armaduras & 4 & 16,67 & 4 & 16,67 & 3 & 12,50 & 2 & 8,33 & & - & 12 & 50,00 & 5 & 20,83 \\
\hline efeito parede & 7 & 29,17 & 6 & 25,00 & 11 & 45,83 & 12 & 50,00 & 7 & 29,17 & 2 & 8,33 & 2 & 8,33 \\
\hline falta de alinhamento horizontal ou vertical & & - & & - & 1 & 4,17 & & - & & - & & - & & - \\
\hline carbonatação na superficie do concreto & & - & & - & & - & & - & & - & & - & & - \\
\hline manchas de corrosão ou armadura corroída & 5 & 20,83 & 1 & 4,17 & & - & & - & & - & 1 & 4,17 & & - \\
\hline fissuras de retração & & - & 0 & - & & - & & - & & - & & - & & - \\
\hline fissuras inclinadas & 6 & 25,00 & 2 & 8,33 & 1 & 4,17 & 6 & 25,00 & & - & 6 & 25,00 & 1 & 4,17 \\
\hline fissuras em tubulação & & - & & - & & - & & - & & - & & - & & - \\
\hline fissuras verticais & & - & & - & & - & & - & & - & & - & & - \\
\hline deformação das fôrmas & & - & & - & & - & & - & & - & & - & & - \\
\hline reparo nos el. estrut. devido segregações & & - & & - & & - & & - & & - & & - & & - \\
\hline lixiviação & 9 & 37,50 & 1 & 4,17 & & - & 7 & 29,17 & & - & 6 & 25,00 & 1 & 4,17 \\
\hline eflorescências & 7 & 29,17 & 1 & 4,17 & & - & 6 & 25,00 & & - & 5 & 20,83 & 1 & 4,17 \\
\hline falta de vibração & 2 & 8,33 & 1 & 4,17 & 2 & 8,33 & & - & & - & & - & 1 & 4,17 \\
\hline desagregação do concreto & & - & & - & & - & & - & & - & & - & & - \\
\hline
\end{tabular}




\section{Elemento estrutural - LAJE}

Número de elementos estruturais ( laje ) por pavimento $=5$

Q = número de manifestações patológicas por pavimento

$\%=$ porcentagem de manifestações patológicas por pavimento

\begin{tabular}{|c|c|c|c|c|c|c|c|c|c|c|c|c|c|c|c|c|}
\hline \multirow{2}{*}{$\begin{array}{l}\text { PAVIMENTO } \\
\text { Tipo de manifestação patológica observada }\end{array}$} & \multicolumn{2}{|c|}{$8^{\circ}$ pavimento } & \multicolumn{2}{|c|}{$9^{\circ}$ pavimento } & \multicolumn{2}{|c|}{$10^{\circ}$ pavimento } & \multicolumn{2}{|c|}{$11^{\circ}$ pavimento } & \multicolumn{2}{|c|}{$12^{\circ}$ pavimento } & \multicolumn{2}{|c|}{$13^{\circ}$ pavimento } & \multicolumn{2}{|c|}{$14^{\circ}$ pavimento } & \multicolumn{2}{|c|}{$15^{\circ}$ pavimento } \\
\hline & @ & $\%$ & @ & $\%$ & @ & $\%$ & @ & $\%$ & @ & $\%$ & $@$ & $\%$ & @ & $\%$ & @ & $\%$ \\
\hline desaprumo & & - & & - & & - & & - & & - & & - & & - & & - \\
\hline torção da fôrma & & - & & - & & - & & - & & - & & - & & - & & - \\
\hline junta de concretagem & & - & & - & & - & & - & & - & & - & & - & & - \\
\hline falta de limpeza das fôrmas & & - & 5 & 20,83 & 6 & 25,00 & 1 & 4,17 & & - & & - & & - & & - \\
\hline falta de estanqueidade das fôrmas & 7 & 29,17 & 4 & 16,67 & 5 & 20,83 & 6 & 25,00 & 9 & 37,50 & 10 & 41,67 & 12 & 50,00 & 9 & 37,50 \\
\hline falta de limpeza elementos estruturais & & - & & - & & - & & - & & - & & - & & - & & - \\
\hline disgregação & & - & 1 & 4,17 & & - & & - & & - & & - & & - & & - \\
\hline bicheiras & & - & & - & & - & & - & & - & & - & & - & & - \\
\hline segregação do concreto & & - & & - & & - & & - & & - & & - & & - & & - \\
\hline falta de cobrimento de proteção das armaduras & 6 & 25,00 & 5 & 20,83 & 6 & 25,00 & 4 & 16,67 & 6 & 25,00 & 2 & 8,33 & 10 & 41,67 & 6 & 25,00 \\
\hline efeito parede & 7 & 29,17 & 7 & 29,17 & 4 & 16,67 & 9 & 37,50 & 3 & 12,50 & 8 & 33,33 & 3 & 12,50 & 1 & 4,17 \\
\hline falta de alinhamento horizontal ou vertical & 1 & 4,17 & 1 & 4,17 & 1 & 4,17 & & - & & - & 1 & 4,17 & & - & 1 & 4,17 \\
\hline carbonatação na superfície do concreto & & - & & - & & - & & - & & - & & - & & - & & - \\
\hline manchas de corrosão ou armadura corroída & & - & & - & & - & & - & & - & & - & & - & & - \\
\hline fissuras de retração & & - & & - & & - & & - & & - & & - & & - & & - \\
\hline fissuras inclinadas & 7 & 29,17 & & - & & - & 11 & 45,83 & 5 & 20,83 & & - & 1 & 4,17 & 7 & 29,17 \\
\hline fissuras em tubulação & & - & & - & & - & & - & & - & & - & & - & & - \\
\hline fissuras verticais & & - & & - & & - & & - & & - & & - & & - & & - \\
\hline deformação das fôrmas & & - & & - & & - & & - & & - & & - & & - & & - \\
\hline reparo nos el. estrut. devido segregaçōes & & - & & - & & - & & - & & - & & - & & - & & - \\
\hline lixiviaçäo & 4 & 16,67 & & - & & - & 19 & 79,17 & 7 & 29,17 & & - & 1 & 4,17 & 7 & 29,17 \\
\hline eflorescências & 4 & 16,67 & & - & & - & 19 & 79,17 & 7 & 29,17 & & - & 1 & 4,17 & 7 & 29,17 \\
\hline falta de vibraçāo & & - & & - & & - & 3 & 12,50 & 2 & 8,33 & 1 & 4,17 & & - & & - \\
\hline desagregação do concreto & & - & & - & & - & & - & & - & & - & & - & & - \\
\hline
\end{tabular}




\section{Elemento estrutural - VIGA}

Número de elementos estruturais (viga) por pavimento $=29$

@ = número de manifestaçöes patológicas por pavimento

$\%=$ porcentagem de manifestações patológicas por pavimento

\begin{tabular}{|c|c|c|c|c|c|c|c|c|c|c|c|c|c|c|}
\hline \multirow{2}{*}{$\begin{array}{l}\text { PAVIMENTO } \\
\text { Tipo de manifestação patológica observada }\end{array}$} & \multicolumn{2}{|c|}{ Térreo } & \multicolumn{2}{|c|}{$2^{\circ}$ pavimento } & \multicolumn{2}{|c|}{$3^{\circ}$ pavimento } & \multicolumn{2}{|c|}{$4^{\circ}$ pavimento } & \multicolumn{2}{|c|}{$5^{\circ}$ pavimento } & \multicolumn{2}{|c|}{$6^{\circ}$ pavimento } & \multicolumn{2}{|c|}{$7^{\circ}$ pavimento } \\
\hline & @ & $\%$ & @ & $\%$ & @ & $\%$ & @ & $\%$ & @ & $\%$ & @ & $\%$ & @ & $\%$ \\
\hline desaprumo & & - & & - & & - & & - & & - & & - & & - \\
\hline torção da fôrma & & - & 2 & 3,92 & 2 & 3,92 & & - & 1 & 1,96 & 2 & 3,92 & 2 & 3,92 \\
\hline junta de concretagem & & - & & - & & - & & - & & - & & - & 1 & 1,96 \\
\hline falta de limpeza das fôrmas & 10 & 19,61 & 5 & 9,80 & 1 & 1,96 & 2 & 3,92 & & - & & - & 3 & 5,88 \\
\hline falta de estanqueidade das fôrmas & 2 & 3,92 & 2 & 3,92 & & - & 3 & 5,88 & & - & 2 & 3,92 & 1 & 1,96 \\
\hline falta de limpeza elementos estruturais & & - & & - & & - & & - & & - & & - & & - \\
\hline disgregação & & - & & - & & - & & - & & - & & - & & - \\
\hline bicheiras & & - & & - & 2 & 3,92 & & - & & - & 5 & 9,80 & 5 & 9,80 \\
\hline segregação do concreto & 2 & 3,92 & 2 & 3,92 & 5 & 9,80 & 3 & 5,88 & 4 & 7,84 & 9 & 17,65 & 6 & 11,76 \\
\hline falta de cobrimento de proteção das armaduras & 9 & 17,65 & 16 & 31,37 & 11 & 21,57 & 9 & 17,65 & 10 & 19,61 & 9 & 17,65 & 17 & 33,33 \\
\hline efeito parede & & - & & - & & - & & - & & - & & - & & - \\
\hline falta de alinhamento horizontal ou vertical & & - & 2 & 3,92 & 2 & 3,92 & 2 & 3,92 & 7 & 13,73 & 4 & 7,84 & 2 & 3,92 \\
\hline carbonatação na superficie do concreto & & - & & - & & - & & - & & - & & - & & - \\
\hline manchas de corrosão ou armadura corroída & & - & & - & & - & & - & & - & 1 & 1,96 & & - \\
\hline fissuras de retração & 6 & 11,76 & & - & & - & & - & & - & & - & & - \\
\hline fissuras inclinadas & & - & & - & & - & & - & & - & & - & & - \\
\hline fissuras em tubulação & & - & & - & & - & & - & 2 & 3,92 & & - & 2 & 3,92 \\
\hline fissuras verticais & & - & & - & 2 & 3,92 & & - & & - & & - & 3 & 5,88 \\
\hline deformação das fôrmas & 2 & 3,92 & 2 & 3,92 & 2 & 3,92 & & - & 1 & 1,96 & & - & 2 & 3,92 \\
\hline reparo nos el. estrut. devido segregaçōes & & - & & - & & - & & - & & - & & - & & - \\
\hline lixiviaçāo & & - & 1 & 1,96 & & - & & - & & - & & - & & - \\
\hline eflorescências & & - & 1 & 1,96 & & - & & - & & - & & - & & - \\
\hline falta de vibração & & - & & - & & - & & - & & - & & - & & - \\
\hline desagregação do concreto & 1 & 1,96 & & - & & - & & - & & - & & - & & - \\
\hline
\end{tabular}


Elemento estrutural - VIGA

Número de elementos estruturais ( viga ) por pavimento $=$

@ = número de manifestações patológicas por pavimento

$\%=$ porcentagem de manifestações patológicas por pavimento

\begin{tabular}{|c|c|c|c|c|c|c|c|c|c|c|c|c|c|c|c|c|}
\hline PAVIMENTO & $8^{\circ}$ & avimento & $9^{\circ} \mathrm{F}$ & avimento & $10^{\circ}$ & avimento & $11^{\circ}$ & avimento & $12^{\circ}$ & avimento & 13 & avimento & $14^{\circ}$ & avimento & $15^{\circ}$ & avimento \\
\hline Tipo de manifestação patológica observada & @ & $\%$ & @ & $\%$ & @ & $\%$ & @ & $\%$ & @ & $\%$ & @ & $\%$ & Q & $\%$ & $@$ & $\%$ \\
\hline desaprumo & & - & & - & & - & & - & & - & & - & & - & & - \\
\hline torção da fôrma & 2 & 3,92 & 1 & 1,96 & 3 & 5,88 & & - & 1 & 1,96 & 2 & 3,92 & 2 & 3,92 & 2 & 3,92 \\
\hline junta de concretagem & 2 & 3,92 & 1 & 1,96 & 3 & 5,88 & & - & 1 & 1,96 & 2 & 3,92 & 2 & 3,92 & 2 & 3,92 \\
\hline falta de limpeza das fôrmas & & - & 1 & 1,96 & & - & 3 & 5,88 & 1 & 1,96 & 1 & 1,96 & & - & & - \\
\hline falta de estanqueidade das forrmas & 3 & 5,88 & 6 & 11,76 & 8 & 15,69 & 6 & 11,76 & 8 & 15,69 & 4 & 7,84 & 9 & 17,65 & 5 & 9,80 \\
\hline falta de limpeza elementos estruturais & & - & & - & & - & & - & & - & & - & & - & & - \\
\hline disgregação & & - & & - & & - & & - & & - & & - & & - & & - \\
\hline bicheiras & & - & 1 & 1,96 & & - & 2 & 3,92 & 3 & 5,88 & 2 & 3,92 & 4 & 7,84 & 6 & 11,76 \\
\hline segregação do concreto & 10 & 19,61 & 11 & 21,57 & 12 & 23,53 & 15 & 29,41 & 14 & 27,45 & 12 & 23,53 & 12 & 23,53 & 14 & 27,45 \\
\hline falta de cobrimento de proteção das armaduras & 10 & 19,61 & 23 & 45,10 & 23 & 45,10 & 17 & 33,33 & 19 & 37,25 & 12 & 23,53 & 10 & 19,61 & 14 & 27,45 \\
\hline efeito parede & & - & & - & & - & & - & & - & & - & & - & & - \\
\hline falta de alinhamento horizontal ou vertical & 2 & 3,92 & 3 & 5,88 & 2 & 3,92 & 2 & 3,92 & 1 & 1,96 & 4 & 7,84 & 3 & 5,88 & 6 & 11,76 \\
\hline carbonatação na superfície do concreto & & - & & - & & - & & - & & - & & - & & - & & - \\
\hline manchas de corrosão ou armadura corroída & & - & & - & & - & 1 & 1,96 & & - & & - & & - & & - \\
\hline fissuras de retração & & - & & - & & - & & - & & - & & - & 2 & 3,92 & & - \\
\hline fissuras inclinadas & & - & & - & & - & & - & & - & & - & & - & & - \\
\hline fissuras em tubulação & & - & 1 & 1,96 & & - & & - & & - & 1 & 1,96 & & - & & - \\
\hline fissuras verticais & 1 & 1,96 & 2 & 3,92 & 1 & 1,96 & 1 & 1,96 & 1 & 1,96 & 1 & 1,96 & & - & 1 & 1,96 \\
\hline deformação das fôrmas & 1 & 1,96 & 5 & 9,80 & 1 & 1,96 & 4 & 7,84 & 4 & 7,84 & 1 & 1,96 & 8 & 15,69 & 5 & 9,80 \\
\hline reparo nos el. estrut. devido segregações & 1 & 1,96 & 2 & 3,92 & & - & 1 & 1,96 & & - & 7 & 13,73 & & - & & - \\
\hline lixiviação & & - & & - & & - & & - & & - & & - & & - & & - \\
\hline eflorescências & & - & & - & & - & & - & & - & & - & & - & & - \\
\hline falta de vibração & & - & & - & & - & & - & & - & & - & & - & & - \\
\hline desagregação do concreto & & - & & - & & - & & - & & - & & - & & - & & - \\
\hline
\end{tabular}




\section{Elemento estrutural - PILAR}

Número de elementos estruturais (pilar) por pavimento $=20$

@ = número de manifestações patológicas por pavimento

$\%=$ porcentagem de manifestações patológicas por pavimento

\begin{tabular}{|c|c|c|c|c|c|c|c|c|c|c|c|c|c|c|}
\hline \multirow{2}{*}{$\begin{array}{l}\text { PAVIMENTO } \\
\text { Tipo de manifestação patológica observada }\end{array}$} & \multicolumn{2}{|c|}{ Térreo } & \multicolumn{2}{|c|}{$2^{\circ}$ pavimento } & \multicolumn{2}{|c|}{$3^{\circ}$ pavimento } & \multicolumn{2}{|c|}{$4^{\circ}$ pavimento } & \multicolumn{2}{|c|}{$5^{\circ}$ pavimento } & \multicolumn{2}{|c|}{$6^{\circ}$ pavimento } & \multicolumn{2}{|c|}{$7^{\circ}$ pavimentc } \\
\hline & @ & $\%$ & @ & $\%$ & @ & $\%$ & @ & $\%$ & @ & $\%$ & @ & $\%$ & @ & $\%$ \\
\hline desaprumo & & - & & - & & - & 1 & 10,00 & 1 & 10,00 & & - & & - \\
\hline torção da fôrma & & - & 1 & 10,00 & & - & & - & & - & & - & 1 & 10,00 \\
\hline junta de concretagem & & - & & - & & - & & - & & - & & - & & - \\
\hline falta de limpeza das fôrmas & & - & & - & 1 & 10,00 & & - & & - & & - & & - \\
\hline falta de estanqueidade das fôrmas & & - & & - & & - & & - & & - & & - & & - \\
\hline falta de limpeza elementos estruturais & & - & & - & & - & & - & & - & & - & & - \\
\hline disgregação & & - & & - & & - & & - & & - & 1 & 10,00 & & - \\
\hline bixeiras & & - & & - & & - & & - & & - & 3 & 30,00 & 1 & 10,00 \\
\hline segregação do concreto & 6 & 60,00 & 4 & 40,00 & 8 & 80,00 & 5 & 50,00 & 2 & 20,00 & 6 & 60,00 & 6 & 60,00 \\
\hline falta de cobrimento de proteção das armaduras & & - & & - & 1 & 10,00 & & - & & - & 2 & 20,00 & & - \\
\hline efeito parede & & - & & - & & - & & - & & - & & - & & - \\
\hline falta de alinhamento horizontal ou vertical & & - & & - & & - & & - & 1 & 10,00 & 2 & 20,00 & 2 & 20,00 \\
\hline carbonatação na superfície do concreto & & - & & - & & - & & - & & - & & - & & - \\
\hline manchas de corrosão ou armadura corroída & & - & & - & & - & & - & & - & & - & & - \\
\hline fissuras de retração & & - & & - & & - & & - & & - & & - & & - \\
\hline fissuras inclinadas & & - & & - & & - & & - & & - & & - & & - \\
\hline fissuras em tubulação & & - & & - & & - & & - & & - & & - & & - \\
\hline fissuras verticais & & - & & - & & - & & - & & - & & - & & - \\
\hline deformação das fôrmas & 1 & 10,00 & 1 & 10,00 & & - & 1 & 10,00 & 5 & 50,00 & 2 & 20,00 & 3 & 30,00 \\
\hline reparo nos el. estrut. devido segregaçōes & & - & 2 & 20,00 & 1 & 10,00 & 1 & 10,00 & & - & & - & & - \\
\hline lixiviaçäo & & - & & - & & - & & - & & - & & - & & - \\
\hline eflorescências & & - & & - & & - & & - & & - & & - & & - \\
\hline falta de vibração & & - & & - & & - & & - & & - & & - & & - \\
\hline desagregação do concreto & & - & & - & & - & & - & & - & & - & & - \\
\hline
\end{tabular}




\section{Elemento estrutural - PILAR}

Número de elementos estruturais ( pilar ) por pavimento =

@ = número de manifestações patológicas por pavimento

$\%$ = porcentagem de manifestações patológicas por pavimento

\begin{tabular}{|c|c|c|c|c|c|c|c|c|c|c|c|c|c|c|c|c|}
\hline \multirow{2}{*}{$\begin{array}{l}\text { PAVIMENTO } \\
\text { Tipo de manifestação patológica observada }\end{array}$} & \multicolumn{2}{|c|}{$8^{\circ}$ pavimento } & \multicolumn{2}{|c|}{$9^{\circ}$ pavimento } & \multicolumn{2}{|c|}{$10^{\circ}$ pavimento } & \multicolumn{2}{|c|}{$11^{\circ}$ pavimento } & \multicolumn{2}{|c|}{$12^{\circ}$ pavimento } & \multicolumn{2}{|c|}{$13^{\circ}$ pavimento } & \multicolumn{2}{|c|}{$14^{\circ}$ pavimento } & \multicolumn{2}{|c|}{$15^{\circ}$ pavimento } \\
\hline & @ & $\%$ & @ & $\%$ & @ & $\%$ & @ & $\%$ & @ & $\%$ & @ & $\%$ & @ & $\%$ & @ & $\%$ \\
\hline desaprumo & & - & & - & & - & & - & & - & & - & & - & & - \\
\hline torção da fôrma & & - & 1 & 10,00 & & - & & - & & - & 1 & 10,00 & 1 & 10,00 & & - \\
\hline junta de concretagem & & - & & - & & - & & - & & - & & - & & - & & - \\
\hline falta de limpeza das fôrmas & & - & & - & & - & & - & & - & & - & & - & 1 & 10,00 \\
\hline falta de estanqueidade das fôrmas & & - & & - & & - & & - & & - & & - & & - & & - \\
\hline falta de limpeza elementos estruturais & & - & & - & & - & & - & & - & & - & & - & & - \\
\hline disgregação & & - & & - & & - & & - & & - & & - & & - & & - \\
\hline bicheiras & & - & & - & 2 & 20,00 & 2 & 20,00 & & - & & - & 1 & 10,00 & 2 & 20,00 \\
\hline segregação do concreto & 11 & 110,00 & 8 & 80,00 & 8 & 80,00 & 13 & 130,00 & 10 & 100,00 & 9 & 90,00 & 11 & 110,00 & 13 & 130,00 \\
\hline falta de cobrimento de proteção das armaduras & & - & & - & 1 & 10,00 & & - & & - & 2 & 20,00 & & - & 3 & 30,00 \\
\hline efeito parede & & - & & - & & - & & - & & - & & - & & - & & - \\
\hline falta de alinhamento horizontal ou vertical & 1 & 10,00 & 1 & 10,00 & 2 & 20,00 & 3 & 30,00 & 4 & 40,00 & 1 & 10,00 & 2 & 20,00 & 1 & 10,00 \\
\hline carbonatação na superfície do concreto & & - & & - & & - & & - & & - & & - & & - & & - \\
\hline manchas de corrosão ou armadura corroída & & - & & - & & - & & - & & - & & - & & - & & - \\
\hline fissuras de retração & & - & & - & & - & & - & & - & & - & & - & & - \\
\hline fissuras inclinadas & & - & & - & & - & & - & & - & & - & & - & & - \\
\hline fissuras em tubulação & & - & & - & & - & & - & & - & & - & & - & & - \\
\hline fissuras verticais & & - & & - & & - & & - & & - & & - & & - & & - \\
\hline deformação das fôrmas & 4 & 40,00 & 8 & 80,00 & 4 & 40,00 & 7 & 70,00 & 7 & 70,00 & 4 & 40,00 & 5 & 50,00 & 4 & 40,00 \\
\hline reparo nos el. estrut. devido segregaçōes & & - & & - & & - & & - & & - & & - & & - & 1 & 10,00 \\
\hline lixiviaçäo & & - & & - & & - & & - & & - & & - & & - & & - \\
\hline eflorescências & & - & & - & & - & & - & & - & & - & & - & & - \\
\hline falta de vibração & & - & & - & & - & & - & & - & & - & & - & & - \\
\hline desagregação do concreto & & - & & - & & - & & - & & - & & - & & - & & - \\
\hline
\end{tabular}




\section{Elemento estrutural - PAREDE}

Número de elementos estruturais (parede) por pavimento $=10$

$@$ = número de manifestações patológicas por pavimento

$\%$ = porcentagem de manifestações patológicas por pavimento

\begin{tabular}{|c|c|c|c|c|c|c|c|c|c|c|c|c|c|c|}
\hline \multirow{2}{*}{$\begin{array}{l}\text { PAVIMENTO } \\
\text { Tipo de manifestação patológica observada }\end{array}$} & \multicolumn{2}{|c|}{ Térreo } & \multicolumn{2}{|c|}{$2^{\circ}$ pavimento } & \multicolumn{2}{|c|}{$3^{\circ}$ pavimento } & \multicolumn{2}{|c|}{$4^{\circ}$ pavimento } & \multicolumn{2}{|c|}{$5^{\circ}$ pavimento } & \multicolumn{2}{|c|}{$6^{\circ}$ pavimento } & \multicolumn{2}{|c|}{$7^{\circ}$ pavimento } \\
\hline & @ & $\%$ & @ & $\%$ & @ & $\%$ & $@$ & $\%$ & @ & $\%$ & $@$ & $\%$ & @ & $\%$ \\
\hline desaprumo & & - & & - & & - & & - & & - & & - & & - \\
\hline torção da fôrma & & - & & - & & - & & - & & - & & - & & - \\
\hline junta de concretagem & & - & & - & & - & & - & & - & & - & & - \\
\hline falta de limpeza das fôrmas & 1 & 10,00 & & - & & - & & - & & - & & - & & - \\
\hline falta de estanqueidade das fôrmas & 1 & 10,00 & 2 & 20,00 & & - & & - & & - & 1 & 10,00 & & - \\
\hline falta de limpeza elementos estruturais & & - & & - & & - & & - & & - & & - & & - \\
\hline disgregação & & - & & - & & - & & - & & - & & - & & - \\
\hline bicheiras & 1 & 10,00 & & - & & - & & - & 2 & 20,00 & 3 & 30,00 & & - \\
\hline segregação do concreto & 5 & 50,00 & 8 & 80,00 & 4 & 40,00 & 4 & 40,00 & 8 & 80,00 & 5 & 50,00 & 9 & 90,00 \\
\hline falta de cobrimento de proteção das armaduras & & - & & - & & - & & - & & - & 1 & 10,00 & & - \\
\hline efeito parede & & - & & - & & - & & - & & - & & - & & - \\
\hline falta de alinhamento horizontal ou vertical & & - & & - & & - & & - & 1 & 10,00 & & - & 2 & 20,00 \\
\hline carbonatação na superficie do concreto & & - & & - & & - & & - & & - & & - & & - \\
\hline manchas de corrosão ou armadura corroída & & - & & - & & - & & - & & - & & - & & - \\
\hline fissuras de retração & & - & & - & & - & & - & & - & & - & & - \\
\hline fissuras inclinadas & & - & & - & & - & & - & & - & & - & & - \\
\hline fissuras em tubulação & & - & & - & & - & & - & & - & & - & & - \\
\hline fissuras verticais & & - & & - & & - & & - & & - & & - & & - \\
\hline deformação das fôrmas & & - & & - & 1 & 10,00 & & - & & - & 1 & 10,00 & 1 & 10,00 \\
\hline reparo nos el. estrut. devido segregaçōes & 3 & 30,00 & 2 & 20,00 & & - & & - & & - & & - & & - \\
\hline lixiviaçäo & & - & & - & & - & & - & & - & & - & & - \\
\hline eflorescências & & - & & - & & - & & - & & - & & - & & - \\
\hline falta de vibração & & - & & - & & - & & - & & - & & - & & - \\
\hline desagregaçäo do concreto & & - & & - & & - & & - & & - & & - & & - \\
\hline
\end{tabular}


Número de elementos estruturais (parede) por pavimento $=10$

@ = número de manifestações patológicas por pavimento

$\%$ = porcentagem de manifestações patológicas por pavimento

\begin{tabular}{|c|c|c|c|c|c|c|c|c|c|c|c|c|c|c|c|c|}
\hline \multirow{2}{*}{$\begin{array}{l}\text { PAVIMENTO } \\
\text { Tipo de manifestação patológica observada }\end{array}$} & \multicolumn{2}{|c|}{$8^{\circ}$ pavimento } & \multicolumn{2}{|c|}{$9^{\circ}$ pavimento } & \multicolumn{2}{|c|}{$10^{\circ}$ pavimento } & \multicolumn{2}{|c|}{$11^{\circ}$ pavimento } & \multicolumn{2}{|c|}{$12^{\circ}$ pavimento } & \multicolumn{2}{|c|}{13 pavimento } & \multicolumn{2}{|c|}{$14^{\circ}$ pavimento } & \multicolumn{2}{|c|}{$15^{\circ}$ pavimento } \\
\hline & @ & $\%$ & @ & $\%$ & @ & $\%$ & @ & $\%$ & @ & $\%$ & @ & $\%$ & @ & $\%$ & @ & $\%$ \\
\hline desaprumo & & - & 1 & 10,00 & & - & & - & & - & & - & & - & & - \\
\hline torção da fôrma & & - & & - & 3 & 30,00 & & - & & - & 1 & 10,00 & 2 & 20,00 & & - \\
\hline junta de concretagem & & - & & - & 1 & 10,00 & & - & & - & & - & & - & & - \\
\hline falta de limpeza das fôrmas & & - & & - & & - & & - & & - & & - & & - & & - \\
\hline falta de estanqueidade das fôrmas & & - & & - & 3 & 30,00 & & - & & - & 1 & 10,00 & 2 & 20,00 & & - \\
\hline falta de limpeza elementos estruturais & & - & & - & & - & & - & & - & & - & & - & & - \\
\hline disgregação & & - & & - & & - & & - & & - & & - & & - & & - \\
\hline bicheiras & & - & 1 & 10,00 & 3 & 30,00 & 3 & 30,00 & & - & 1 & 10,00 & 2 & 20,00 & 5 & 50,00 \\
\hline segregação do concreto & 3 & 30,00 & 8 & 80,00 & 5 & 50,00 & 12 & 120,00 & 12 & 120,00 & 8 & 80,00 & 8 & 80,00 & 9 & 90,00 \\
\hline falta de cobrimento de proteção das armaduras & & - & & - & & - & 1 & 10,00 & & - & & - & & - & 1 & 10,00 \\
\hline efeito parede & & - & & - & & - & & - & & - & & - & & - & & - \\
\hline falta de alinhamento horizontal ou vertical & & - & & - & & - & 1 & 10,00 & 2 & 20,00 & & - & 1 & 10,00 & 1 & 10,00 \\
\hline carbonatação na superficie do concreto & & - & & - & & - & & - & & - & & - & & - & & - \\
\hline manchas de corrosão ou armadura corroída & & - & & - & & - & & - & & - & & - & & - & 1 & 10,00 \\
\hline fissuras de retração & & - & & - & & - & & - & & - & & - & & - & & - \\
\hline fissuras inclinadas & & - & & - & & - & & - & & - & & - & & - & & - \\
\hline fissuras em tubulação & & - & & - & & - & & - & & - & & - & & - & & - \\
\hline fissuras verticais & & - & & - & & - & & - & & - & & - & & - & & - \\
\hline deformação das formas & & - & 1 & 10,00 & 1 & 10,00 & 3 & 30,00 & 4 & 40,00 & 4 & 40,00 & & - & 2 & 20,00 \\
\hline reparo nos el. estrut. devido segregações & & - & & - & & - & & - & & - & & - & & - & & - \\
\hline lixiviaçăo & & - & & - & & - & & - & & - & & - & & - & & - \\
\hline eflorescências & & - & & - & & - & & - & & - & & - & & - & & - \\
\hline falta de vibração & & - & & - & & - & & - & & - & & - & & - & & - \\
\hline desagregação do concreto & & - & & - & & - & & - & & - & & - & & - & & - \\
\hline
\end{tabular}


ANEXO D - Tabelas quantitativas das ocorrências de cada elemento estrutural do Edifício D 
Elemento estrutural - LAJE

Número de elementos estruturais (laje) por pavimento $=13$

@Q = número de manifestaçőes patológicas por pavimento

$\%=$ porcentagem de manifestaçöes patológicas por pavimento

\begin{tabular}{|c|c|c|c|c|c|c|c|c|c|c|c|c|}
\hline \multirow{2}{*}{$\begin{array}{l}\text { PAVIMENTO } \\
\text { Tipo de manifestação patológica observada }\end{array}$} & \multicolumn{2}{|c|}{ Térreo } & \multicolumn{2}{|c|}{$1^{\circ}$ pavimento } & \multicolumn{2}{|c|}{$2^{\circ}$ pavimento } & \multicolumn{2}{|c|}{$3^{\circ}$ pavimento } & \multicolumn{2}{|c|}{$4^{0}$ pavimento } & \multicolumn{2}{|c|}{$5^{\circ}$ pavimento } \\
\hline & @ & $\%$ & @ & $\%$ & @ & $\%$ & @ & $\%$ & @ & $\%$ & @ & $\%$ \\
\hline desaprumo & & - & & - & & - & & - & & - & & - \\
\hline torção da fôrma & & - & & - & & - & & - & & - & & - \\
\hline junta de concretagem & & - & & - & 1 & 7,69 & 3 & 23,08 & 1 & 7,69 & & - \\
\hline falta de limpeza das fôrmas & & - & & - & & - & & - & & - & & - \\
\hline falta de estanqueidade das fôrmas & 1 & 7,69 & 2 & 15,38 & 9 & 69,23 & 13 & 100,00 & 11 & 84,62 & 9 & 69,23 \\
\hline falta de limpeza elementos estruturais & & - & & - & & - & 2 & 15,38 & 1 & 7,69 & 3 & 23,08 \\
\hline disgregação & & - & & - & & - & & - & & - & & - \\
\hline bicheiras & & - & & - & & - & & - & & - & & - \\
\hline segregação do concreto & 2 & 15,38 & & - & & - & 3 & 23,08 & 3 & 23,08 & 10 & 76,92 \\
\hline falta de cobrimento de proteção das armaduras & & - & & - & & - & 2 & 15,38 & 8 & 61,54 & 4 & 30,77 \\
\hline efeito parede & 10 & 76,92 & 8 & 61,54 & 10 & 76,92 & 7 & 53,85 & & - & & - \\
\hline falta de alinhamento horizontal ou vertical & & - & 1 & 7,69 & 4 & 30,77 & 6 & 46,15 & 9 & 69,23 & 8 & 61,54 \\
\hline carbonatação na superficie do concreto & & - & & - & & - & & - & & - & & - \\
\hline manchas de corrosão ou armadura corroída & 1 & 7,69 & 6 & 46,15 & & - & 4 & 30,77 & 3 & 23,08 & 5 & 38,46 \\
\hline fissuras de retração & & - & & - & & - & & - & & - & & - \\
\hline fissuras inclinadas & 2 & 15,38 & 11 & 84,62 & 1 & 7,69 & 4 & 30,77 & 4 & 30,77 & 6 & 46,15 \\
\hline fissuras em tubulação & & - & & - & & - & & - & & - & & - \\
\hline fissuras verticais & & - & & - & & - & & - & & - & & - \\
\hline deformaçāo das fôrmas & & - & & - & 3 & 23,08 & 1 & 7,69 & 1 & 7,69 & & - \\
\hline reparo nos el. estrut. devido segregaçōes & 1 & 7,69 & & - & 1 & 7,69 & & - & & - & & - \\
\hline lixiviaçäo & 2 & 15,38 & 9 & 69,23 & 2 & 15,38 & 8 & 61,54 & 6 & 46,15 & 5 & 38,46 \\
\hline eflorescências & 2 & 15,38 & 9 & 69,23 & 2 & 15,38 & 8 & 61,54 & 6 & 46,15 & 5 & 38,46 \\
\hline falta de vibração & 1 & 7,69 & & - & & - & 1 & 7,69 & 5 & 38,46 & 2 & 15,38 \\
\hline desagregação do concreto & & - & & - & & - & & - & & - & & - \\
\hline
\end{tabular}




\section{Elemento estrutural - LAJE}

Número de elementos estruturais ( laje ) por pavimento $=13$

@ = número de manifestaçöes patológicas por pavimento

$\%=$ porcentagem de manifestaçőes patológicas por pavimento

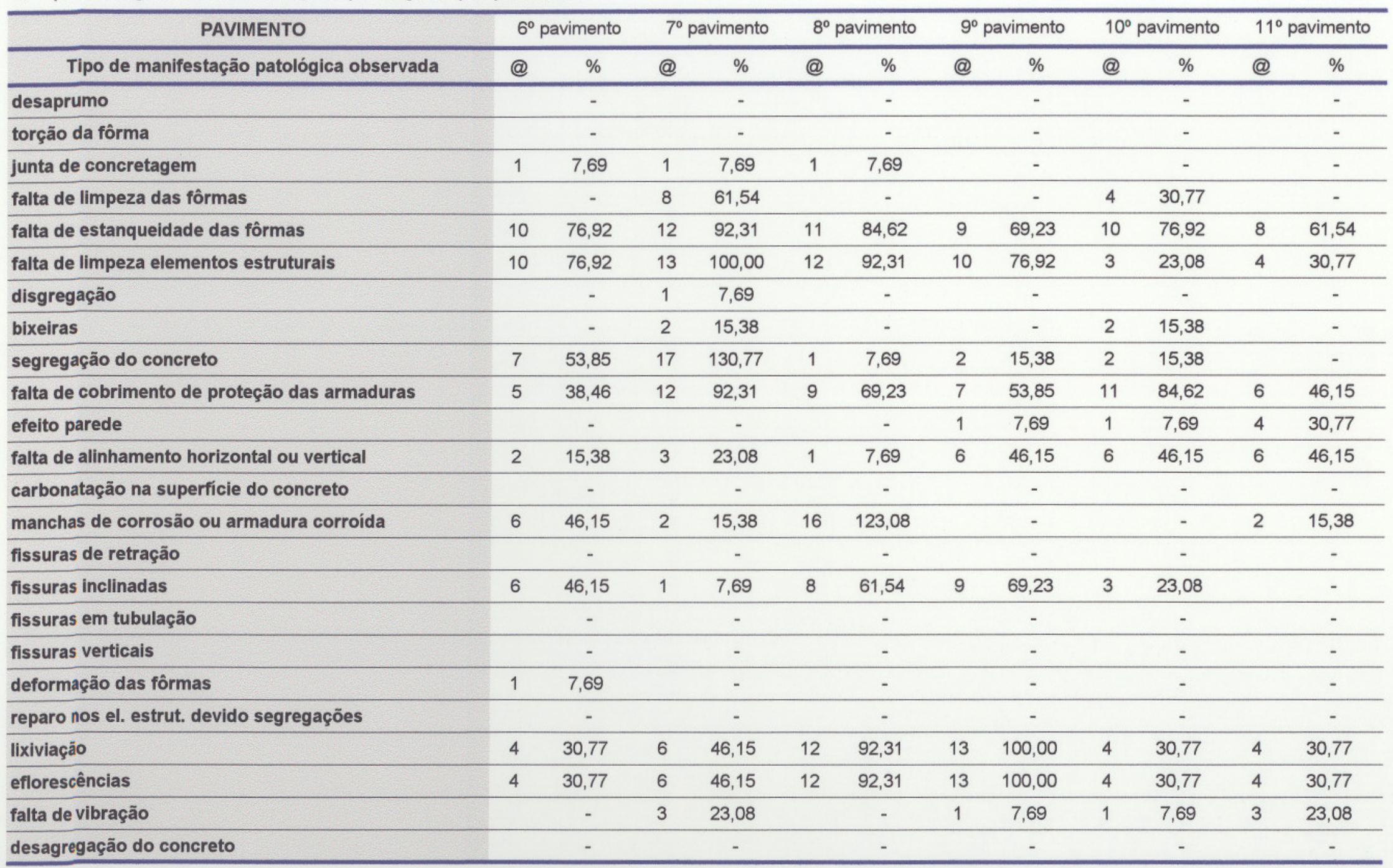


Elemento estrutural - VIGA

Número de elementos estruturais (viga) por pavimento $=40$

Q = número de manifestações patológicas por pavimento

$\%=$ porcentagem de manifestações patológicas por pavimento PAVIMENTO Térreo

$1^{\circ}$ pavimento $\quad 2^{\circ}$ pavimento $\quad 3^{\circ}$ pavimento $\quad 4^{\circ}$ pavimento $\quad 5^{\circ}$ pavimento

Tipo de manifestação patológica observada

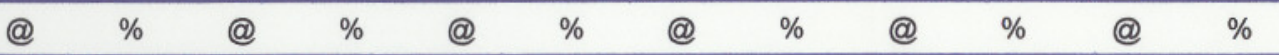

desaprumo

@ $\%$

torção da fôrma

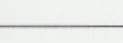

junta de concretagem

falta de limpeza das fôrmas

falta de estanqueidade das fôrmas

falta de limpeza elementos estruturais

disgregação

bicheiras

segregação

falta de cobrimento de proteção das armaduras

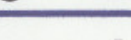

@ \%

@ \%

@ \%

$-$

efeito parede

falta de alinhamento horizontal ou vertical

12,50

2,50

carbonatação na superfície do concreto

manchas de corrosão ou armadura corroída

fissuras de retração

fissuras inclinadas

fissuras em tubulação

fissuras verticais

deformação das fôrmas

reparo nos el. estrut. devido segregaçōes

lixiviação

eflorescências

falta de vibração

desagregação do concreto

\begin{tabular}{|c|c|c|c|c|c|c|c|c|c|c|c|}
\hline & - & & - & 4 & 10,00 & 3 & 7,50 & 2 & 5,00 & 3 & 7,50 \\
\hline & - & & - & 1 & 2,50 & 1 & 2,50 & 2 & 5,00 & 1 & 2,50 \\
\hline 2 & 5,00 & 1 & 2,50 & 1 & 2,50 & 14 & 35,00 & 7 & 17,50 & 9 & 22,50 \\
\hline 1 & 2,50 & 1 & 2,50 & & - & 8 & 20,00 & 4 & 10,00 & 4 & 10,00 \\
\hline \multirow[t]{2}{*}{1} & 2,50 & & - & & - & & - & & - & 1 & 2,50 \\
\hline & - & & - & & - & & - & & - & 1 & 2,50 \\
\hline 3 & 7,50 & 4 & 10,00 & 9 & 22,50 & 13 & 32,50 & 17 & 42,50 & 9 & 22,50 \\
\hline 25 & 62,50 & 13 & 32,50 & 13 & 32,50 & 21 & 52,50 & 16 & 40,00 & 14 & 35,00 \\
\hline
\end{tabular}

\begin{tabular}{llllllllllll}
2 & 5,00 & 1 & 2,50 & 4 & 10,00 & 5 & 12,50 & 6 & 15,00 & 6 & 15,00 \\
\hline
\end{tabular}




\section{Elemento estrutural - VIGA}

Número de elementos estruturais ( viga $)$ por pavimento $=40$

@ = número de manifestaçőes patológicas por pavimento

$\%=$ porcentagem de manifestaçőes patológicas por pavimento

\begin{tabular}{|c|c|c|c|c|c|c|c|c|c|c|c|c|}
\hline \multirow{2}{*}{$\begin{array}{l}\text { PAVIMENTO } \\
\text { Tipo de manifestação patológica observada }\end{array}$} & \multicolumn{2}{|c|}{$6^{\circ}$ pavimento } & \multicolumn{2}{|c|}{$7^{\circ}$ pavimento } & \multicolumn{2}{|c|}{$8^{\circ}$ pavimento } & \multicolumn{2}{|c|}{$9^{\circ}$ pavimento } & \multicolumn{2}{|c|}{$10^{\circ}$ pavimento } & \multicolumn{2}{|c|}{$11^{\circ}$ pavimento } \\
\hline & @ & $\%$ & $@$ & $\%$ & @ & $\%$ & @ & $\%$ & @ & $\%$ & @ & $\%$ \\
\hline desaprumo & & - & & - & & - & & - & & - & & - \\
\hline torção da fôrma & 1 & 2,50 & & - & & - & 1 & 2,50 & & - & 2 & 5,00 \\
\hline junta de concretagem & 1 & 2,50 & 1 & 2,50 & 3 & 7,50 & & - & & - & 1 & 2,50 \\
\hline falta de limpeza das fôrmas & & - & 5 & 12,50 & 1 & 2,50 & 1 & 2,50 & 1 & 2,50 & 2 & 5,00 \\
\hline falta de estanqueidade das fôrmas & 5 & 12,50 & 10 & 25,00 & 11 & 27,50 & 3 & 7,50 & 2 & 5,00 & & - \\
\hline falta de limpeza elementos estruturais & 4 & 10,00 & 7 & 17,50 & 16 & 40,00 & 11 & 27,50 & 6 & 15,00 & 13 & 32,50 \\
\hline disgregação & & - & & - & & - & & - & & - & & - \\
\hline bicheiras & 1 & 2,50 & 1 & 2,50 & & - & 1 & 2,50 & 3 & 7,50 & 3 & 7,50 \\
\hline segregação do concreto & 18 & 45,00 & 18 & 45,00 & 10 & 25,00 & 13 & 32,50 & 12 & 30,00 & 7 & 17,50 \\
\hline falta de cobrimento de proteção das armaduras & 13 & 32,50 & 21 & 52,50 & 15 & 37,50 & 13 & 32,50 & 17 & 42,50 & 14 & 35,00 \\
\hline efeito parede & & - & & - & & - & & - & & - & & - \\
\hline falta de alinhamento horizontal ou vertical & & - & 4 & 10,00 & 3 & 7,50 & 5 & 12,50 & 11 & 27,50 & 14 & 35,00 \\
\hline carbonatação na superficie do concreto & & - & & - & & - & & - & & - & & - \\
\hline manchas de corrosão ou armadura corroída & 1 & 2,50 & & - & & - & & - & & - & & - \\
\hline fissuras de retração & & - & & - & & - & & - & & - & & - \\
\hline fissuras inclinadas & & - & & - & & - & & - & & - & & - \\
\hline fissuras em tubulaçāo & & - & & - & & - & & - & & - & 3 & 7,50 \\
\hline fissuras verticais & & - & & - & & - & & - & 1 & 2,50 & & - \\
\hline deformação das fôrmas & 5 & 12,50 & 3 & 7,50 & 6 & 15,00 & 4 & 10,00 & 2 & 5,00 & 4 & 10,00 \\
\hline reparo nos el. estrut. devido segregaçōes & 1 & 2,50 & & - & & - & & - & & - & & - \\
\hline lixiviaçắo & & - & & - & & - & & - & & - & 1 & 2,50 \\
\hline eflorescências & & - & & - & & - & & - & & - & 1 & 2,50 \\
\hline falta de vibração & & - & & - & & - & & - & & - & & - \\
\hline desagregação do concreto & & - & & - & & - & & - & & - & & - \\
\hline
\end{tabular}




\section{Elemento estrutural - PILAR}

Número de elementos estruturais (pilar) por pavimento $=17$

@ = número de manifestações patológicas por pavimento

$\%=$ porcentagem de manifestações patológicas por pavimento

\begin{tabular}{|c|c|c|c|c|c|c|c|c|c|c|c|c|}
\hline \multirow{2}{*}{$\begin{array}{l}\text { PAVIMENTO } \\
\text { Tipo de manifestação patológica observada }\end{array}$} & \multicolumn{2}{|c|}{ Térreo } & \multicolumn{2}{|c|}{$1^{\circ}$ pavimento } & \multicolumn{2}{|c|}{$2^{\circ}$ pavimento } & \multicolumn{2}{|c|}{$3^{\circ}$ pavimento } & \multicolumn{2}{|c|}{$4^{\circ}$ pavimento } & \multicolumn{2}{|c|}{$5^{\circ}$ pavimentc } \\
\hline & @ & $\%$ & @ & $\%$ & $@$ & $\%$ & @ & $\%$ & @ & $\%$ & @ & $\%$ \\
\hline desaprumo & & - & & - & & - & & - & & - & & - \\
\hline torção da fôrma & & - & & - & & - & & - & & - & & - \\
\hline junta de concretagem & & - & & - & & - & & - & & - & & - \\
\hline falta de limpeza das fôrmas & & - & & - & & - & & - & 1 & 5,88 & & - \\
\hline falta de estanqueidade das fôrmas & & - & & - & & - & & - & & - & & - \\
\hline falta de limpeza dos elementos estruturais & & - & & - & & - & 1 & 5,88 & & - & & - \\
\hline disgregação & & - & & - & & - & & - & & - & & - \\
\hline bicheiras & & - & & - & & - & 1 & 5,88 & 1 & 5,88 & 2 & 11,76 \\
\hline segregação do concreto & 7 & 41,18 & 4 & 23,53 & 12 & 70,59 & 9 & 52,94 & 9 & 52,94 & 12 & 70,59 \\
\hline falta de cobrimento de proteção das armaduras & & - & & - & 1 & 5,88 & & - & & - & 2 & 11,76 \\
\hline efeito parede & & - & & - & & - & & - & & - & & - \\
\hline falta de alinhamento horizontal ou vertical & & - & & - & & - & & - & & - & 1 & 5,88 \\
\hline carbonatação na superficie do concreto & & - & & - & & - & & - & & - & & - \\
\hline manchas de corrosão ou armadura corroída & & - & & - & & - & & - & & - & & - \\
\hline fissuras de retração & & - & & - & & - & & - & & - & & - \\
\hline fissuras inclinadas & & - & & - & & - & & - & & - & & - \\
\hline fissuras em tubulação & & - & & - & & - & & - & & - & & - \\
\hline fissuras verticais & & - & & - & & - & & - & & - & & - \\
\hline deformação das fôrmas & & - & & - & & - & & - & 1 & 5,88 & 1 & 5,88 \\
\hline reparo nos el. estrut. devido segregaçōes & 6 & 35,29 & 1 & 5,88 & 3 & 17,65 & 2 & 11,76 & 3 & 17,65 & & - \\
\hline lixiviaçāo & & - & & - & & - & & - & & - & & - \\
\hline eflorescências & & - & & - & & - & & - & & - & & - \\
\hline falta de vibração & & - & & - & & - & & - & & - & & - \\
\hline desagregação do concreto & & - & & - & & - & & - & & - & & - \\
\hline
\end{tabular}




\section{Elemento estrutural - PILAR}

Número de elementos estruturais ( pilar ) por pavimento $=17$

(Q) = número de manifestaçőes patológicas por pavimento

$\%=$ porcentagem de manifestações patológicas por pavimento

\begin{tabular}{|c|c|c|c|c|c|c|c|c|c|c|c|c|}
\hline \multirow{2}{*}{$\begin{array}{l}\text { PAVIMENTO } \\
\text { Tipo de manifestação patológica observada }\end{array}$} & \multicolumn{2}{|c|}{$6^{\circ}$ pavimento } & \multicolumn{2}{|c|}{$7^{\circ}$ pavimento } & \multicolumn{2}{|c|}{$8^{\circ}$ pavimento } & \multicolumn{2}{|c|}{$9^{\circ}$ pavimento } & \multicolumn{2}{|c|}{$10^{\circ}$ pavimento } & \multicolumn{2}{|c|}{$11^{\circ}$ pavimento } \\
\hline & @ & $\%$ & @ & $\%$ & @ & $\%$ & @ & $\%$ & @ & $\%$ & @ & $\%$ \\
\hline desaprumo & & - & & - & & - & & - & & - & & - \\
\hline torção da fôrma & & - & & - & & - & & - & & - & 3 & 17,65 \\
\hline junta de concretagem & & - & & - & & - & & - & & - & & - \\
\hline falta de limpeza das fôrmas & & - & & - & & - & & - & & - & & - \\
\hline falta de estanqueidade das fôrmas & & - & & - & & - & & - & & - & & - \\
\hline falta de limpeza elementos estruturais & & - & & - & & - & & - & & - & 2 & 11,76 \\
\hline disgregação & & - & & - & & - & & - & & - & & - \\
\hline bicheiras & & - & 2 & 11,76 & & - & 2 & 11,76 & & - & 2 & 11,76 \\
\hline segregação do concreto & 4 & 23,53 & 3 & 17,65 & 6 & 35,29 & 10 & 58,82 & 5 & 29,41 & 3 & 17,65 \\
\hline falta de cobrimento de proteção das armaduras & & - & & - & 1 & 5,88 & 1 & 5,88 & & - & 1 & 5,88 \\
\hline efeito parede & & - & & - & & - & & - & & - & & - \\
\hline falta de alinhamento horizontal ou vertical & & - & & - & & - & & - & & - & 2 & 11,76 \\
\hline carbonatação na superfície do concreto & & - & & - & & - & & - & & - & & - \\
\hline manchas de corrosão ou armadura corroída & & - & & - & & - & & - & & - & & - \\
\hline fissuras de retração & & - & & - & & - & & - & & - & & - \\
\hline fissuras inclinadas & & - & & - & & - & & - & & - & & - \\
\hline fissuras em tubulação & & - & & - & & - & & - & & - & & - \\
\hline fissuras verticais & & - & & - & & - & & - & & - & & - \\
\hline deformação das fôrmas & & - & & - & 3 & 17,65 & & - & 3 & 17,65 & 5 & 29,41 \\
\hline reparo nos el. estrut. devido segregaçōes & & - & & - & & - & & - & & - & & - \\
\hline lixiviaçäo & & - & & - & & - & & - & & - & & - \\
\hline eflorescências & & - & & - & & - & & - & & - & & - \\
\hline falta de vibração & & - & & - & & - & & - & & - & & - \\
\hline desagregação do concreto & & - & & - & & - & & - & & - & & - \\
\hline
\end{tabular}




\section{Elemento estrutural - PAREDE}

Número de elementos estruturais (parede) por pavimento $=9$

@ = número de manifestações patológicas por pavimento

$\%$ = porcentagem de manifestações patológicas por pavimento

\begin{tabular}{|c|c|c|c|c|c|c|c|c|c|c|c|c|}
\hline \multirow{2}{*}{$\begin{array}{l}\text { PAVIMENTO } \\
\text { Tipo de manifestação patológica observada }\end{array}$} & \multicolumn{2}{|c|}{ Térreo } & \multicolumn{2}{|c|}{$1^{\circ}$ pavimento } & \multicolumn{2}{|c|}{$2^{\circ}$ pavimento. } & \multicolumn{2}{|c|}{$3^{\circ}$ pavimento } & \multicolumn{2}{|c|}{$4^{\circ}$ pavimento } & \multicolumn{2}{|c|}{$5^{\circ}$ pavimento } \\
\hline & @ & $\%$ & @ & $\%$ & @ & $\%$ & @ & $\%$ & @ & $\%$ & @ & $\%$ \\
\hline desaprumo & & - & & - & & - & & - & & - & & - \\
\hline torção da fôrma & & - & & - & & - & & - & & - & & - \\
\hline junta de concretagem & & - & & - & 1 & 11,11 & & - & & - & & - \\
\hline falta de limpeza das fôrmas & & - & & - & 1 & 11,11 & & - & & - & & - \\
\hline falta de estanqueidade das fôrmas & & - & & - & & - & & - & & - & & - \\
\hline falta de limpeza elementos estruturais & & - & & - & & - & & - & 2 & 22,22 & & - \\
\hline disgregação & & - & & - & & - & & - & & - & & - \\
\hline bicheiras & & - & & - & & - & & - & 2 & 22,22 & 1 & 11,11 \\
\hline segregação do concreto & 7 & 77,78 & 3 & 33,33 & 12 & 133,33 & 8 & 88,89 & 8 & 88,89 & 8 & 88,89 \\
\hline falta de cobrimento de proteção das armaduras & 1 & 11,11 & & - & & - & & - & & - & & - \\
\hline efeito parede & & - & & - & & - & & - & & - & & - \\
\hline falta de alinhamento horizontal ou vertical & 1 & 11,11 & 1 & 11,11 & 1 & 11,11 & & - & & - & & - \\
\hline carbonatação na superfície do concreto & & - & & - & & - & & - & & - & & - \\
\hline manchas de corrosão ou armadura corroída & & - & & - & & - & & - & & - & & - \\
\hline fissuras de retração & & - & & - & & - & & - & & - & & - \\
\hline fissuras inclinadas & & - & & - & & - & & - & & - & & - \\
\hline fissuras em tubulação & & - & & - & & - & & - & & - & & - \\
\hline fissuras verticais & & - & & - & & - & & - & & - & & - \\
\hline deformação das fôrmas & 1 & 11,11 & & - & & - & 1 & 11,11 & 1 & 11,11 & 3 & 33,33 \\
\hline reparo nos el. estrut. devido segregaçōes & 5 & 55,56 & & - & 3 & 33,33 & 6 & 66,67 & 1 & 11,11 & 1 & 11,11 \\
\hline lixiviaçāo & & - & & - & & - & & - & & - & & - \\
\hline eflorescências & & - & & - & & - & & - & & - & & - \\
\hline falta de vibração & & - & & - & & - & & - & & - & & - \\
\hline desagregação do concreto & & - & & - & & - & & - & & - & & - \\
\hline
\end{tabular}




\section{Elemento estrutural - PAREDE}

Número de elementos estruturais (parede) por pavimento $=9$

@ = número de manifestações patológicas por pavimento

$\%=$ porcentagem de manifestações patológicas por pavimento

\begin{tabular}{|c|c|c|c|c|c|c|c|c|c|c|c|c|}
\hline \multirow{2}{*}{$\begin{array}{l}\text { PAVIMENTO } \\
\text { Tipo de manifestação patológica observada }\end{array}$} & \multicolumn{2}{|c|}{$6^{\circ}$ pavimento } & \multicolumn{2}{|c|}{$7^{\circ}$ pavimento. } & \multicolumn{2}{|c|}{$8^{\circ}$ pavimento } & \multicolumn{2}{|c|}{$9^{\circ}$ pavimento } & \multicolumn{2}{|c|}{$10^{\circ}$ pavimento } & \multicolumn{2}{|c|}{$11^{\circ}$ pavimento } \\
\hline & $@$ & $\%$ & $@$ & $\%$ & @ & $\%$ & @ & $\%$ & @ & $\%$ & @ & $\%$ \\
\hline desaprumo & & - & & - & & - & & - & & - & & - \\
\hline torção da fôrma & & - & 2 & 22,22 & & - & & - & & - & 1 & 11,11 \\
\hline junta de concretagem & & - & & - & & - & & - & & - & & - \\
\hline falta de limpeza das fôrmas & & - & & - & & - & & - & & - & & - \\
\hline falta de estanqueidade das fôrmas & & - & & - & & - & & - & & - & & - \\
\hline falta de limpeza elementos estruturais & & - & & - & & - & & - & & - & 4 & 44,44 \\
\hline disgregação & & - & & - & & - & & - & & - & & - \\
\hline bicheiras & & - & 3 & 33,33 & 1 & 11,11 & 3 & 33,33 & & - & 2 & 22,22 \\
\hline segregaçäo do concreto & 8 & 88,89 & 5 & 55,56 & 11 & 122,22 & 5 & 55,56 & 4 & 44,44 & 7 & 77,78 \\
\hline falta de cobrimento de proteção das armaduras & & - & 1 & 11,11 & & - & 2 & 22,22 & & - & & - \\
\hline efeito parede & & - & & - & & - & & - & & - & & - \\
\hline falta de alinhamento horizontal ou vertical & & - & & - & & - & & - & & - & & - \\
\hline carbonatação na superficie do concreto & & - & & - & & - & & - & & - & & - \\
\hline manchas de corrosão ou armadura corroída & & - & & - & & - & & - & & - & & - \\
\hline fissuras de retração & & - & & - & & - & & - & & - & & - \\
\hline fissuras inclinadas & & - & & - & & - & & - & & - & & - \\
\hline fissuras em tubulação & & - & & - & & - & & - & & - & & - \\
\hline fissuras verticais & & - & & - & & - & & - & & - & & - \\
\hline deformação das fôrmas & 2 & 22,22 & 3 & 33,33 & 5 & 55,56 & 5 & 55,56 & 2 & 22,22 & 7 & 77,78 \\
\hline reparo nos el. estrut. devido segregaçöes & 1 & 11,11 & & - & 1 & 11,11 & & - & & - & 2 & 22,22 \\
\hline lixiviação & & - & & - & & - & & - & & - & & - \\
\hline eflorescências & & - & & - & & - & & - & & - & & - \\
\hline falta de vibraçāo & & - & & - & & - & & - & & - & & - \\
\hline desagregação do concreto & & - & & - & & - & & - & & - & & - \\
\hline
\end{tabular}


ANEXO E - Tabelas quantitativas das ocorrências de cada elemento estrutural do Edifício E 


\section{Elemento estrutural - LAJE}

Número de elementos estruturais (laje) por pavimento $=5$

@ = número de manifestações patológicas por pavimento

$\%$ = porcentagem de manifestações patológicas por pavimento

\begin{tabular}{|c|c|c|c|c|c|c|c|c|c|c|c|c|c|c|}
\hline \multirow{2}{*}{$\begin{array}{l}\text { PAVIMENTO } \\
\text { Tipo de manifestação patológica observada }\end{array}$} & \multicolumn{2}{|c|}{ Térreo } & \multicolumn{2}{|c|}{$1^{\circ}$ pavimento } & \multicolumn{2}{|c|}{$2^{\circ}$ pavimento } & \multicolumn{2}{|c|}{$3^{\circ}$ pavimento } & \multicolumn{2}{|c|}{$4^{\circ}$ pavimento } & \multicolumn{2}{|c|}{$5^{\circ}$ pavimento } & \multicolumn{2}{|c|}{$6^{\circ}$ pavimento } \\
\hline & @ & $\%$ & @ & $\%$ & @ & $\%$ & @ & $\%$ & @ & $\%$ & @ & $\%$ & @ & $\%$ \\
\hline desaprumo & & - & & - & & - & & - & & - & & - & & - \\
\hline torção da fôrma & & - & & - & & - & & - & & - & & - & & - \\
\hline junta de concretagem & & - & & - & & - & & - & & - & & - & & - \\
\hline falta de limpeza das fôrmas & 1 & 20,00 & & - & & - & & - & 2 & 40,00 & & - & & - \\
\hline falta de estanqueidade das fôrmas & & - & 1 & 20,00 & 2 & 40,00 & 3 & 60,00 & 3 & 60,00 & 3 & 60,00 & 3 & 60,00 \\
\hline falta de limpeza nos elementos estruturais & & - & & - & & - & & - & & - & & - & & - \\
\hline disgregação & & - & & - & & - & & - & & - & & - & & - \\
\hline bicheiras & & - & & - & & - & & - & 1 & 20,00 & 2 & 40,00 & 0 & - \\
\hline segregação do concreto & 1 & 20,00 & 1 & 20,00 & 1 & 20,00 & 2 & 40,00 & 3 & 60,00 & 2 & 40,00 & 2 & 40,00 \\
\hline falta de cobrimento de proteção das armaduras & & - & 2 & 40,00 & 3 & 60,00 & 2 & 40,00 & 3 & 60,00 & 3 & 60,00 & 3 & 60,00 \\
\hline efeito parede & & - & & - & 1 & 20,00 & 2 & 40,00 & 3 & 60,00 & 3 & 60,00 & 3 & 60,00 \\
\hline falta de alinhamento horizontal ou vertical & & - & 1 & 20,00 & 0 & - & 1 & 20,00 & 0 & - & 1 & 20,00 & 0 & - \\
\hline carbonatação na superficie do concreto & & - & & - & & - & & - & & - & & - & 0 & - \\
\hline manchas de corrosão ou armadura corroída & & - & & - & & - & & - & & - & & - & 0 & - \\
\hline fissuras de retração & & - & & - & & - & & - & & - & & - & 0 & - \\
\hline fissuras inclinadas & & - & & - & & - & & - & & - & & - & & - \\
\hline fissuras em tubulação & & - & & - & & - & & - & & - & & - & & - \\
\hline fissuras verticais & & - & & - & & - & & - & & - & & - & & - \\
\hline deformação das fôrmas & & - & & - & 1 & 20,00 & 2 & 40,00 & 2 & 40,00 & 2 & 40,00 & 3 & 60,00 \\
\hline reparo nos el. estrut. devido segregaçōes & & - & & - & & - & & - & & - & & - & & - \\
\hline lixiviação & & - & & - & & - & & - & & - & & - & & - \\
\hline eflorescências & & - & & - & & - & & - & & - & & - & & - \\
\hline falta de vibração & 2 & 40,00 & 1 & 20,00 & & - & 2 & 40,00 & 3 & 60,00 & 3 & 60,00 & 3 & 60,00 \\
\hline desagregação do concreto & & - & & - & & - & & - & & - & & - & & - \\
\hline
\end{tabular}




\section{Elemento estrutural - VIGA}

Número de elementos estruturais (viga) por pavimento $=27$

@ = número de manifestaçōes patológicas por pavimento

$\%=$ porcentagem de manifestações patológicas por pavimento

\begin{tabular}{|c|c|c|c|c|c|c|c|c|c|c|c|c|c|c|}
\hline PAVIMENTO & & rreo & $1^{\circ} \mathrm{p}$ & vimento & $2^{\circ} \mathrm{p}$ & vimento & $3^{\circ} \mathrm{p}$ & vimento & $4^{\circ} \mathrm{p}$ & vimento & $5^{\circ} \mathrm{p}$ & vimento & & vimento \\
\hline Tipo de manifestação patológica observada & @ & $\%$ & @ & $\%$ & $@$ & $\%$ & $@$ & $\%$ & @ & $\%$ & @ & $\%$ & $@$ & $\%$ \\
\hline desaprumo & & - & & - & & - & & - & & - & & - & & - \\
\hline torção da fôrma & & - & & - & & - & & - & 0 & - & & - & & - \\
\hline junta de concretagem & & - & 0 & - & 1 & 3,70 & & - & 1 & 3,70 & & - & & - \\
\hline falta de limpeza das formas & 1 & 3,70 & 0 & - & 3 & 11,11 & 1 & 3,70 & 2 & 7,41 & 5 & 18,52 & 3 & 11,11 \\
\hline falta de estanqueidade das fôrmas & 5 & 18,52 & 7 & 25,93 & 8 & 29,63 & 10 & 37,04 & 12 & 44,44 & 15 & 55,56 & 15 & 55,56 \\
\hline falta de limpeza nos elementos estruturais & & - & 0 & - & & - & & - & 0 & - & & - & & - \\
\hline disgregação & & - & 0 & - & & - & 1 & 3,70 & 0 & - & 0 & - & 0 & - \\
\hline bicheiras & & - & 0 & - & & - & & - & 2 & 7,41 & 2 & 7,41 & 1 & 3,70 \\
\hline segregação do concreto & 2 & 7,41 & 5 & 18,52 & 6 & 22,22 & 8 & 29,63 & 10 & 37,04 & 15 & 55,56 & 10 & 37,04 \\
\hline falta de cobrimento de proteção das armaduras & 7 & 25,93 & 10 & 37,04 & 12 & 44,44 & 13 & 48,15 & 13 & 48,15 & 20 & 74,07 & 21 & 77,78 \\
\hline efeito parede & & - & 0 & - & & - & & - & 0 & - & & - & 0 & - \\
\hline falta de alinhamento horizontal ou vertical & 0 & - & 2 & 7,41 & 3 & 11,11 & 2 & 7,41 & 3 & 11,11 & 4 & 14,81 & 2 & 7,41 \\
\hline carbonatação na superfície do concreto & & - & 0 & - & & - & & - & 0 & - & & - & 0 & - \\
\hline manchas de corrosão ou armadura corroída & 0 & - & 1 & 3,70 & 0 & - & 0 & - & 0 & - & 0 & - & 0 & - \\
\hline fissuras de retração & & - & & - & & - & 0 & - & 0 & - & & - & & - \\
\hline fissuras inclinadas & & - & & - & & - & & - & 0 & - & & - & & - \\
\hline fissuras em tubulação & 0 & - & 0 & - & 0 & - & 0 & - & 0 & - & 0 & - & 0 & - \\
\hline fissuras verticais & & - & 0 & - & & - & 0 & - & 0 & - & & - & & - \\
\hline deformação das fôrmas & & - & 1 & 3,70 & 1 & 3,70 & 3 & 11,11 & 4 & 14,81 & 6 & 22,22 & 8 & 29,63 \\
\hline reparo nos el. estrut. devido segregaçōes & & - & & - & & - & & - & & - & & - & & - \\
\hline lixiviaçăo & & - & & - & & - & & - & & - & & - & & - \\
\hline eflorescências & & - & 0 & - & & - & & - & & - & & - & & - \\
\hline falta de vibração & & - & & - & & - & & - & & - & & - & & - \\
\hline desagregação do concreto & & - & & - & & - & & - & & - & & - & & - \\
\hline
\end{tabular}


Elemento estrutural - PILAR

Número de elementos estruturais (pilar) por pavimento $=20$

@ = número de manifestaçöes patológicas por pavimento

$\%=$ porcentagem de manifestações patológicas por pavimento

PAVIMENTO

Tipo de manifestação patológica observada

Térreo

$1^{\circ}$ pavimento $2^{\circ}$ pavimento

$3^{\circ}$ pavimento

$4^{\circ}$ pavimento $5^{\circ}$ pavimento

$6^{\circ}$ pavimento

desaprumo

torção da fôrma

junta de concretagem

falta de limpeza das fôrmas

falta de estanqueidade das fôrmas

falta de limpeza elementos estruturais

disgregação

bicheiras

segregação do concreto

falta de cobrimento de proteção das armaduras

efeito parede

(Q) \%

$\begin{array}{lllllllllllll}\% & 0 & \% & @ & \% & 0 & \% & @ & \% & 0 & \% & @ & \% \\ - & & - & & - & & - & & - & & - & & -\end{array}$

$\begin{array}{lllllllllllll}\% & @ & \% & @ & \% & @ & \% & @ & \% & @ & \% & @ & \% \\ - & & - & & - & & - & & - & & - & & -\end{array}$

falta de alinhamento horizontal ou vertical

carbonatação na superficie do concreto

manchas de corrosão ou armadura corroída

fissuras de retração

fissuras inclinadas

fissuras em tubulação

fissuras verticais

deformação das fôrmas

reparo nos el. estrut. devido segregaçōes

lixiviaçăo

eflorescências

falta de vibração

desagregação do concreto

\begin{tabular}{|c|c|c|c|c|c|c|c|c|c|c|c|c|}
\hline- & & - & & - & & - & & - & & - & & - \\
\hline- & & - & & - & & - & & - & & - & & - \\
\hline- & & - & 2 & 10,00 & & - & & - & & - & 1 & 5,00 \\
\hline- & & - & & - & & - & & - & & - & & - \\
\hline- & & - & & - & & - & & - & & - & & - \\
\hline- & & - & & - & & - & & - & & - & & - \\
\hline 10,00 & & - & 3 & 15,00 & 2 & 10,00 & 3 & 15,00 & 3 & 15,00 & 2 & 10,00 \\
\hline 25,00 & 6 & 30,00 & 8 & 40,00 & 10 & 50,00 & 7 & 35,00 & 5 & 25,00 & 7 & 35,00 \\
\hline- & 0 & - & 2 & 10,00 & 1 & 5,00 & 3 & 15,00 & 3 & 15,00 & 2 & 10,00 \\
\hline- & & - & & - & & - & 0 & - & & - & & - \\
\hline- & 3 & 15,00 & 2 & 10,00 & 1 & 5,00 & 2 & 10,00 & 0 & - & 1 & 5,00 \\
\hline- & & - & & - & & - & & - & & - & & - \\
\hline- & & - & & - & & - & & - & & - & & - \\
\hline- & & - & & - & & - & 0 & - & & - & & - \\
\hline - & & - & & - & & - & & - & 0 & - & 0 & - \\
\hline- & & - & & - & & - & & - & & - & & - \\
\hline- & & - & & - & & - & & - & & - & & - \\
\hline- & & - & 1 & 5,00 & 2 & 10,00 & 3 & 15,00 & 1 & 5,00 & 4 & 20,00 \\
\hline- & & - & 1 & 5,00 & & - & 2 & 10,00 & 0 & - & 1 & 5,00 \\
\hline - & & - & & - & & - & & - & & - & & - \\
\hline- & & - & & - & & - & & - & & - & & - \\
\hline- & & - & & - & & - & & - & & - & & - \\
\hline- & & - & & - & & - & & - & & - & & - \\
\hline
\end{tabular}




\section{Elemento estrutural - PAREDE}

Número de elementos estruturais (parede) por pavimento $=8$

@ = número de manifestaçōes patológicas por pavimento

$\%=$ porcentagem de manifestações patológicas por pavimento

\begin{tabular}{|c|c|c|c|c|c|c|c|c|c|c|c|c|c|c|}
\hline \multirow{2}{*}{$\begin{array}{l}\text { PAVIMENTO } \\
\text { Tipo de manifestação patológica observada }\end{array}$} & \multicolumn{2}{|c|}{ Térreo } & \multicolumn{2}{|c|}{$1^{\circ}$ pavimento } & \multicolumn{2}{|c|}{$2^{\circ}$ pavimento } & \multicolumn{2}{|c|}{$3^{\circ}$ pavimento } & \multicolumn{2}{|c|}{$4^{\circ}$ pavimento } & \multicolumn{2}{|c|}{$5^{\circ}$ pavimento } & \multicolumn{2}{|c|}{$6^{\circ}$ pavimento } \\
\hline & @ & $\%$ & @ & $\%$ & @ & $\%$ & @ & $\%$ & @ & $\%$ & @ & $\%$ & @ & $\%$ \\
\hline desaprumo & & - & & - & & - & & - & & - & & - & & - \\
\hline torção da fôrma & & - & & - & & - & & - & & - & & - & & - \\
\hline junta de concretagem & & - & & - & & - & & - & & - & & - & & - \\
\hline falta de limpeza das fôrmas & 0 & - & 0 & - & 0 & - & 0 & - & 1 & 12,50 & 1 & 12,50 & 0 & - \\
\hline falta de estanqueidade & 0 & - & 2 & 25,00 & 1 & 12,50 & 2 & 25,00 & 3 & 37,50 & 2 & 25,00 & 3 & 37,50 \\
\hline falta de limpeza nos elementos estruturais & & - & & - & & - & & - & & - & & - & 0 & - \\
\hline disgregação & & - & & - & & - & & - & & - & & - & 0 & - \\
\hline bicheiras & & - & 1 & 12,50 & & - & 1 & 12,50 & 1 & 12,50 & 2 & 25,00 & 1 & 12,50 \\
\hline segregação do concreto & 3 & 37,50 & 4 & 50,00 & 5 & 62,50 & 5 & 62,50 & 6 & 75,00 & 7 & 87,50 & 6 & 75,00 \\
\hline falta de cobrimento de proteção das armaduras & 3 & 37,50 & 1 & 12,50 & 0 & - & 1 & 12,50 & 2 & 25,00 & 0 & - & 1 & 12,50 \\
\hline efeito parede & 0 & - & 0 & - & 0 & - & 0 & - & 0 & - & 0 & - & 0 & - \\
\hline falta de alinhamento horizontal ou vertical & 1 & 12,50 & 2 & 25,00 & 3 & 37,50 & 2 & 25,00 & 1 & 12,50 & & - & 2 & 25,00 \\
\hline carbonatação na superfície do concreto & & - & 0 & - & & - & & - & & - & & - & 0 & - \\
\hline manchas de corrosão ou armadura corroída & 1 & 12,50 & 0 & - & & - & & - & 0 & - & 0 & - & 0 & - \\
\hline fissuras de retração & & - & & - & & - & & - & & - & & - & & - \\
\hline fissuras inclinadas & & - & 0 & - & & - & & - & & - & & - & & - \\
\hline fissuras em tubulação & & - & & - & & - & & - & & - & & - & & - \\
\hline fissuras verticais & & - & & - & & - & & - & & - & & - & & - \\
\hline deformação das fôrmas & & - & 0 & - & 1 & 12,50 & 3 & 37,50 & 3 & 37,50 & 5 & 62,50 & 5 & 62,50 \\
\hline reparo nos el. estrut. devido segregaçōes & & - & & - & & - & & - & & - & & - & & - \\
\hline lixiviaçåo & & - & 0 & - & & - & & - & & - & & - & & - \\
\hline eflorescências & & - & 0 & - & & - & & - & & - & & - & & - \\
\hline falta de vibração & & - & & - & & - & & - & & - & & - & & - \\
\hline desagregação do concreto & & - & & - & & - & & - & & - & & - & & - \\
\hline
\end{tabular}


ANEXO F - Tabelas quantitativas das ocorrências de cada elemento estrutural do Edifício $\mathrm{F}$ 


\section{Elemento estrutural - LAJE}

Número de elementos estruturais (laje) por pavimento $=14$

@ = número de manifestações patológicas por pavimento

$\%=$ porcentagem de manifestações patológicas por pavimento

\begin{tabular}{|c|c|c|c|c|c|c|c|c|}
\hline \multirow{2}{*}{$\begin{array}{l}\text { PAVIMENTO } \\
\text { Tipo de manifestação patológica observada }\end{array}$} & \multicolumn{2}{|c|}{ Térreo } & \multicolumn{2}{|c|}{$1^{\circ}$ pavimento } & \multicolumn{2}{|c|}{$2^{\circ}$ pavimento } & \multicolumn{2}{|c|}{$3^{\circ}$ pavimento } \\
\hline & @ & $\%$ & @ & $\%$ & @ & $\%$ & @ & $\%$ \\
\hline desaprumo & & - & & - & & - & & - \\
\hline torção da fôrma & & - & & - & & - & & - \\
\hline junta de concretagem & & - & & - & & - & & - \\
\hline falta de limpeza das fôrmas & & - & 7 & 50,00 & & - & 3 & 21,43 \\
\hline falta de estanqueidade & 0 & - & 0 & - & 0 & - & 0 & - \\
\hline falta de limpeza nos elementos estruturais & & - & & - & 1 & 7,14 & & - \\
\hline disgregação & & - & & - & 2 & 14,29 & 3 & 21,43 \\
\hline bicheiras & & - & & - & & - & & - \\
\hline segregação do concreto & & - & 5 & 35,71 & & - & & - \\
\hline falta de cobrimento de proteção das armaduras & & - & 15 & 107,14 & 3 & 21,43 & 4 & 28,57 \\
\hline efeito parede & & - & & - & & - & 2 & 14,29 \\
\hline falta de alinhamento horizontal ou vertical & 9 & 64,29 & 11 & 78,57 & 10 & 71,43 & 12 & 85,71 \\
\hline carbonatação na superficie do concreto & 14 & 100,00 & 14 & 100,00 & 14 & 100,00 & 14 & 100,00 \\
\hline manchas de corrosão ou armadura corroída & & - & 4 & 28,57 & 1 & 7,14 & 2 & 14,29 \\
\hline fissuras de retração & & - & & - & & - & & - \\
\hline fissuras inclinadas & 1 & 7,14 & 3 & 21,43 & 5 & 35,71 & 2 & 14,29 \\
\hline fissuras em tubulação & & - & & - & & - & & - \\
\hline fissuras verticais & & - & & - & & - & & - \\
\hline deformação das fôrmas & & - & & - & & - & & - \\
\hline reparo nos el. estrut. devido segregaçōes & & - & 5 & 35,71 & & - & & - \\
\hline lixiviaçăo & & - & & - & 2 & 14,29 & 1 & 7,14 \\
\hline eflorescências & & - & 2 & 14,29 & 2 & 14,29 & 1 & 7,14 \\
\hline falta de vibraçāo & & - & & - & 1 & 7,14 & 2 & 14,29 \\
\hline desagregação do concreto & & - & & - & & - & & - \\
\hline
\end{tabular}




\section{Elemento estrutural - VIGA}

Número de elementos estruturais (viga) por pavimento $=30$

@ = número de manifestaçöes patológicas por pavimento

$\%=$ porcentagem de manifestações patológicas por pavimento

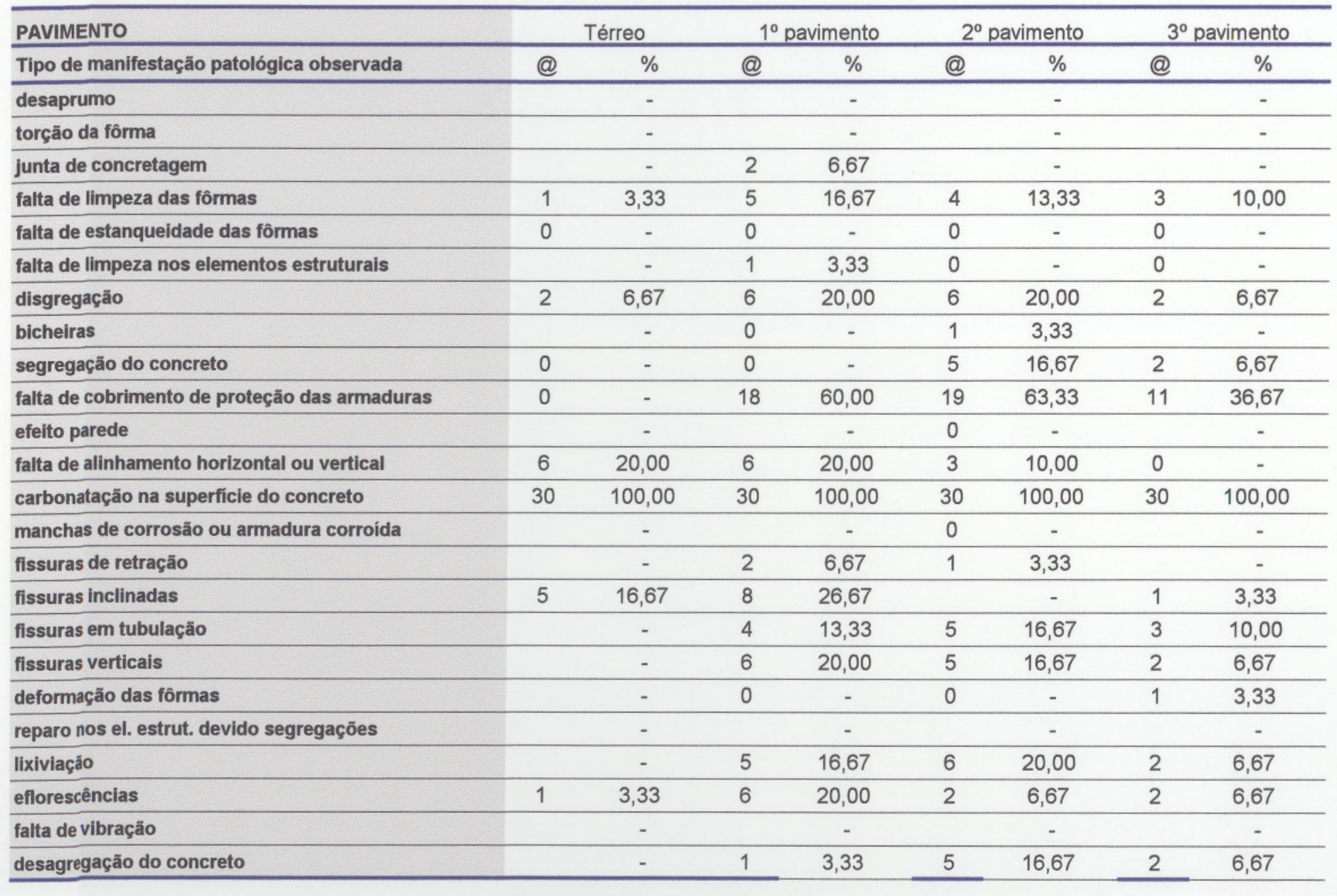




\section{Elemento estrutural - PILAR}

Número de elementos estruturais (pilar) por pavimento $=20$

(10) = número de manifestações patológicas por pavimento

$\%=$ porcentagem de manifestacōes patológicas por pavimento

PAVIMENTO

Térreo

$2^{\circ}$ pavimento

$3^{\circ}$ pavimento

Tipo de manifestação patológica observada

desaprumo

@

$\%$

torção da fôrma

junta de concretagem

falta de limpeza das fôrmas

falta de estanqueidade das fôrmas

falta de limpeza elementos estruturais

disgregação

(Q) \%

(Q) \%

@

$1 \quad 5,00 \quad 1 \quad 5,00$

$\%$

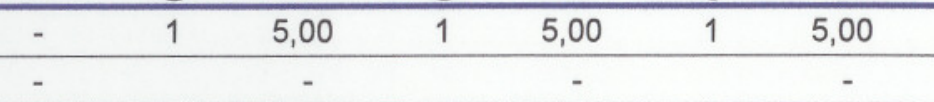

bicheiras

segregação do concreto

\begin{tabular}{|c|c|c|c|c|c|c|c|}
\hline & - & 1 & 5,00 & 5 & 25,00 & & - \\
\hline & - & & - & 1 & 5,00 & & - \\
\hline & - & & - & & - & & - \\
\hline & - & & - & & - & & - \\
\hline & - & & - & 1 & 5,00 & & - \\
\hline & - & 0 & - & 2 & 10,00 & 1 & 5,00 \\
\hline \multirow[t]{3}{*}{6} & 30,00 & 15 & 75,00 & 18 & 90,00 & 10 & 50,00 \\
\hline & - & & - & 1 & 5,00 & 1 & 5,00 \\
\hline & - & & - & & - & & - \\
\hline 0 & - & 0 & - & 1 & 5,00 & 0 & - \\
\hline \multirow[t]{2}{*}{20} & 100,00 & 20 & 100,00 & 20 & 100,00 & 20 & 100,00 \\
\hline & - & & - & 1 & 5,00 & 1 & 5,00 \\
\hline \multirow[t]{5}{*}{9} & 45,00 & 16 & 80,00 & 10 & 50,00 & 1 & 5,00 \\
\hline & - & & - & & - & & - \\
\hline & - & & - & & - & & - \\
\hline & - & & - & & - & & - \\
\hline & - & 0 & - & 2 & 10,00 & 2 & 10,00 \\
\hline \multirow[t]{5}{*}{2} & 10,00 & & - & & - & & - \\
\hline & - & & - & 2 & 10,00 & & - \\
\hline & - & & - & & - & 1 & 5,00 \\
\hline & - & & - & & - & & - \\
\hline & - & & - & & - & & - \\
\hline
\end{tabular}

falta de cobrimento de proteção das armaduras

efeito parede

falta de alinhamento horizontal ou vertical

carbonataçāo na superficie do concreto

manchas de corrosão ou armadura corroída

fissuras de retração

fissuras inclinadas

fissuras em tubulação

fissuras verticais

deformação das fôrmas

reparo nos el. estrut. devido segregaçōes

lixiviaçăo

eflorescências

falta de vibração

desagregação do concreto 
ANEXO G - Tabelas quantitativas das ocorrências de cada elemento estrutural do Edifício $G$ 


\section{Elemento estrutural - LAJE}

Número de elementos estruturais (laje) por pavimento $=3$

Q = número de manifestações patológicas por pavimento

$\%=$ porcentagem de manifestaçőes patológicas por pavimento

\begin{tabular}{|c|c|c|c|c|c|c|c|c|c|c|c|c|c|c|}
\hline PAVIMENTO & & érreo & $1^{\circ} \mathrm{pe}$ & avimento & $2^{\circ} \mathrm{pa}$ & ivimento & $3^{\circ} \mathrm{pe}$ & avimento & $4^{\circ} \mathrm{pe}$ & vimento & $5^{\circ} \mathrm{pe}$ & avimento & $6^{\circ} \mathrm{pa}$ & avimento \\
\hline Tipo de manifestação patológica observada & @ & $\%$ & (1) & $\%$ & @ & $\%$ & @ & $\%$ & @ & $\%$ & (1) & $\%$ & (1) & $\%$ \\
\hline desaprumo & & - & & - & & - & & - & & - & & - & & - \\
\hline torção da fôrma & & - & & - & & - & & - & & - & & - & & - \\
\hline junta de concretagem & & - & & - & & - & & - & & - & & - & & - \\
\hline falta de limpeza das fôrmas & & - & & - & & - & & - & & - & & - & & - \\
\hline falta de estanqueidade das fôrmas & & - & & - & & - & & - & 4 & 133,33 & 4 & 133,33 & 3 & 100,00 \\
\hline disgregação & & - & & - & & - & & - & 1 & 33,33 & & - & 3 & 100,00 \\
\hline bicheiras & & - & & - & 3 & 100,00 & & - & 1 & 33,33 & & - & 1 & 33,33 \\
\hline segregação do concreto & & - & & - & 7 & 233,33 & 2 & 66,67 & 1 & 33,33 & & - & 5 & 166,67 \\
\hline falta de cobrimento de proteção das armaduras & & - & 8 & 266,67 & 2 & 66,67 & & - & & - & & - & 3 & 100,00 \\
\hline efeito parede & & - & & - & & - & & - & & - & & - & & - \\
\hline falta de alinhamento horizontal ou vertical & & - & & - & & - & 5 & 166,67 & 3 & 100,00 & 1 & 33,33 & & - \\
\hline manchas de corrosão ou armadura corroída & & - & 6 & 200,00 & & - & & - & 2 & 66,67 & 12 & 400,00 & 5 & 166,67 \\
\hline fissuras de retração & & - & & - & & - & & - & & - & & - & & - \\
\hline fissuras inclinadas & & - & & - & & - & & - & 7 & 233,33 & 19 & 633,33 & 9 & 300,00 \\
\hline fissuras em tubulação & & - & & - & & - & & - & & - & & - & & - \\
\hline fissuras verticais & & - & & - & & - & & - & & - & & - & & - \\
\hline deformação das fôrmas & & - & & - & & - & & - & & - & & - & & - \\
\hline reparos nos el. estrut. devido segregações & 2 & 66,67 & & - & 13 & 433,33 & 2 & 66,67 & & - & & - & & - \\
\hline lixiviaçāo & & - & & - & & - & & - & 7 & 233,33 & 24 & 800,00 & 12 & 400,00 \\
\hline eflorescências & & - & & - & & - & & - & 7 & 233,33 & 24 & 800,00 & 12 & 400,00 \\
\hline falta de vibração & & - & & - & & - & & - & & - & & - & & - \\
\hline desagregação do concreto & & - & & - & & - & & - & & - & & - & & - \\
\hline mal posicionamento de armadura & & - & 8 & 266,67 & 1 & 33,33 & & - & & - & & - & & - \\
\hline
\end{tabular}


Número de elementos estruturais ( laje $)$ por pavimento $=3$

@ = número de manifestaçőes patológicas por pavimento

$\%=$ porcentagem de manifestaçöes patológicas por pavimento

\begin{tabular}{|c|c|c|c|c|c|c|c|c|c|c|c|c|c|c|c|c|}
\hline PAVIMENTO & $7^{\circ} \mathrm{p}$ & avimento & $8^{\circ} \mathrm{p}$ & avimento & $9^{\circ} \mathrm{pe}$ & avimento & $10^{\circ} \mathrm{F}$ & avimento & $11^{\circ} \mathrm{p}$ & avimento & $12^{\circ}$ & pavimento & 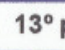 & avimento & $14^{\circ} \mathrm{F}$ & avimento \\
\hline Tipo de manifestaçäo patológica observada & @ & $\%$ & @ & $\%$ & $@$ & $\%$ & @ & $\%$ & @ & $\%$ & @ & $\%$ & @ & $\%$ & @ & $\%$ \\
\hline desaprumo & & - & & - & & - & & - & & - & & - & & - & & - \\
\hline torção da fôrma & & - & & - & & - & & - & & - & & - & & - & & - \\
\hline junta de concretagem & 1 & 33,33 & & - & & - & & - & & - & & - & & - & & - \\
\hline falta de limpeza das fôrmas & & - & & - & & - & & - & & - & & - & & - & & - \\
\hline falta de estanqueidade das fôrmas & 3 & 100,00 & 2 & 66,67 & 3 & 100,00 & 3 & 100,00 & 3 & 100,00 & 3 & 100,00 & 3 & 100,00 & 3 & 100,00 \\
\hline falta de limpeza nos elementos estruturais & & - & & - & & - & & - & & - & 1 & 33,33 & 1 & 33,33 & 1 & 33,33 \\
\hline disgregação & 2 & 66,67 & 3 & 100,00 & 1 & 33,33 & & - & & - & & - & & - & & - \\
\hline bicheiras & 1 & 33,33 & & - & & - & & - & & - & & - & & - & & - \\
\hline segregaçâa do concreto & 6 & 200,00 & 7 & 233,33 & 8 & 266,67 & 4 & 133,33 & 8 & 266,67 & 7 & 233,33 & 13 & 433,33 & 14 & 466,67 \\
\hline falta de cobrimento de proteção das armaduras & 3 & 100,00 & 1 & 33,33 & & - & & - & & - & & - & & - & & - \\
\hline efeito parede & & - & 1 & 33,33 & 1 & 33,33 & & - & & - & 1 & 33,33 & & - & & - \\
\hline falta de alinhamento horizontal ou vertical & 3 & 100,00 & 1 & 33,33 & 1 & 33,33 & 2 & 66,67 & 2 & 66,67 & 2 & 66,67 & 2 & 66,67 & 2 & 66,67 \\
\hline carbonatação na superfície de concreto & 4 & 133,33 & 1 & 33,33 & & - & & - & & - & 1 & 33,33 & & - & & - \\
\hline manchas de corrosão ou armadura corroída & 2 & 66,67 & 4 & 133,33 & 3 & 100,00 & & - & & - & & - & & - & 3 & 100,00 \\
\hline fissuras de retração & & - & & - & & - & & - & & - & & - & & - & & - \\
\hline fissuras inclinadas & & - & 1 & 33,33 & & - & & - & & - & & - & 1 & 33,33 & 1 & 33,33 \\
\hline fissuras em tubulação & & - & & - & & - & & - & & - & & - & & - & & - \\
\hline fissuras verticais & & - & & - & & - & & - & & - & & - & & - & & - \\
\hline deformação das fôrmas & & - & & - & & - & & - & & - & 1 & 33,33 & & - & & - \\
\hline reparos nos el. estrut. devido segregaçōes & & - & & - & & - & & - & & - & & - & & - & & - \\
\hline lixiviaçäo & 4 & 133,33 & 1 & 33,33 & & - & & - & & - & 1 & 33,33 & & - & & - \\
\hline eflorescências & 4 & 133,33 & 1 & 33,33 & & - & & - & & - & 1 & 33,33 & & - & & - \\
\hline falta de vibração & & - & & - & & - & & - & & - & & - & & - & & - \\
\hline desagregação do concreto & & - & & - & & - & & - & & - & & - & & - & & - \\
\hline mal posicionamento de armadura & & - & & - & & - & & - & & - & & - & & & & - \\
\hline
\end{tabular}


Número de elementos estruturais (viga) por pavimento $=24$

@ = número de manifestações patológicas por pavimento

$\%=$ porcentagem de manifestações patológicas por pavimento

\begin{tabular}{|c|c|c|c|c|c|c|c|c|c|c|c|c|c|c|}
\hline \multirow{2}{*}{$\begin{array}{l}\text { PAVIMENTO } \\
\text { Tipo de manifestação patológica observada }\end{array}$} & \multicolumn{2}{|c|}{ Térreo } & \multicolumn{2}{|c|}{$1^{\circ}$ pavimento } & \multicolumn{2}{|c|}{$2^{\circ}$ pavimento } & \multicolumn{2}{|c|}{$3^{\circ}$ pavimento } & \multicolumn{2}{|c|}{$4^{\circ}$ pavimento } & \multicolumn{2}{|c|}{$5^{\circ}$ pavimento } & \multicolumn{2}{|c|}{$6^{\circ}$ pavimento } \\
\hline & @ & $\%$ & @ & $\%$ & @ & $\%$ & @ & $\%$ & @ & $\%$ & @ & $\%$ & @ & $\%$ \\
\hline desaprumo & & - & & - & & - & & - & & - & & - & & - \\
\hline torção da fôrma & & - & 2 & 8,33 & 1 & 4,17 & & - & 1 & 4,17 & 1 & 4,17 & 1 & 4,17 \\
\hline junta de concretagem & & - & & - & & - & & - & & - & & - & & - \\
\hline falta de limpeza das fôrmas & & - & & - & 7 & 29,17 & 1 & 4,17 & 4 & 16,67 & 1 & 4,17 & 2 & 8,33 \\
\hline falta de estanqueidade das fôrmas & 1 & 4,17 & & - & & - & & - & 1 & 4,17 & & - & & - \\
\hline falta de limpeza elementos estruturais & & - & & - & & - & & - & & - & & - & & - \\
\hline disgregação & 2 & 8,33 & 7 & 29,17 & 6 & 25,00 & 2 & 8,33 & 1 & 4,17 & & - & 5 & 20,83 \\
\hline bicheiras & & - & & - & & - & & - & & - & 1 & 4,17 & & - \\
\hline segregação do concreto & & - & & - & & - & & - & & - & & - & 1 & 4,17 \\
\hline falta de cobrimento de proteção das armaduras & 6 & 25,00 & 11 & 45,83 & 16 & 66,67 & 12 & 50,00 & 10 & 41,67 & 4 & 16,67 & 10 & 41,67 \\
\hline efeito parede & & - & & - & & - & & - & & - & & - & & - \\
\hline falta de alinhamento horizontal ou vertical & & - & 1 & 4,17 & 5 & 20,83 & 7 & 29,17 & 8 & 33,33 & 8 & 33,33 & 6 & 25,00 \\
\hline carbonatação na superficie de concreto & & - & & - & & - & & - & & - & & - & & - \\
\hline manchas de corrosão ou armadura corroída & 10 & 41,67 & 22 & 91,67 & 16 & 66,67 & 13 & 54,17 & 12 & 50,00 & 4 & 16,67 & 12 & 50,00 \\
\hline fissuras de retração & & - & & - & & - & & - & & - & & - & & - \\
\hline fissuras inclinadas & & - & & - & & - & & - & & - & & - & & - \\
\hline fissuras em tubulação & & - & & - & & - & & - & & - & & - & & - \\
\hline fissuras verticais & & - & & - & & - & & - & & - & & - & & - \\
\hline deformação das formas & & - & & - & & - & 2 & 8,33 & 1 & 4,17 & 3 & 12,50 & 3 & 12,50 \\
\hline reparos nos el. estrut. devido segregaçōes & & - & & - & & - & & - & & - & & - & & - \\
\hline lixiviação & & - & & - & & - & & - & 1 & 4,17 & 2 & 8,33 & 2 & 8,33 \\
\hline eflorescências & & - & & - & & - & & - & 1 & 4,17 & 2 & 8,33 & 2 & 8,33 \\
\hline falta de vibração & & - & & - & & - & & - & & - & & - & & - \\
\hline desagregação do concreto & & - & & - & & - & & - & & - & & - & & - \\
\hline mal posicionamento de armadura & & - & 5 & 20,83 & 2 & 8,33 & 2 & 8,33 & & - & & - & & - \\
\hline
\end{tabular}


Número de elementos estruturais (viga) por pavimento $=24$

@ = número de manifestações patológicas por pavimento

$\%$ = porcentagem de manifestações patológicas por pavimento

\begin{tabular}{|c|c|c|c|c|c|c|c|c|c|c|c|c|c|c|c|c|}
\hline \multirow{2}{*}{$\begin{array}{l}\text { PAVIMENTO } \\
\text { Tipo de manifestação patológica observada }\end{array}$} & \multicolumn{2}{|c|}{$7^{\circ}$ pavimento } & \multicolumn{2}{|c|}{$8^{\circ}$ pavimento } & \multicolumn{2}{|c|}{$9^{\circ}$ pavimento } & \multicolumn{2}{|c|}{$10^{\circ}$ pavimento } & \multicolumn{2}{|c|}{$11^{\circ}$ pavimento } & \multicolumn{2}{|c|}{$12^{\circ}$ pavimento } & \multicolumn{2}{|c|}{$13^{\circ}$ pavimento } & \multicolumn{2}{|c|}{$14^{\circ}$ pavimento } \\
\hline & @ & $\%$ & @ & $\%$ & @ & $\%$ & @ & $\%$ & @ & $\%$ & @ & $\%$ & @ & $\%$ & @ & $\%$ \\
\hline desaprumo & & - & & - & & - & & - & & - & & - & 1 & 4,17 & & - \\
\hline torção da fôrma & 1 & 4,17 & 1 & 4,17 & 2 & 8,33 & 1 & 4,17 & 1 & 4,17 & & - & & - & & - \\
\hline junta de concretagem & 2 & 8,33 & 2 & 8,33 & 1 & 4,17 & & - & 1 & 4,17 & 2 & 8,33 & & - & & - \\
\hline falta de limpeza das fôrmas & 1 & 4,17 & & - & & - & & - & 2 & 8,33 & 1 & 4,17 & & - & 1 & 4,17 \\
\hline falta de estanqueidade das fôrmas & 2 & 8,33 & 1 & 4,17 & 2 & 8,33 & 3 & 12,50 & 3 & 12,50 & 3 & 12,50 & & - & & - \\
\hline falta de limpeza nos elementos estruturais & 2 & 8,33 & 2 & 8,33 & & - & 1 & 4,17 & 1 & 4,17 & 6 & 25,00 & 4 & 16,67 & 8 & 33,33 \\
\hline disgregação & 4 & 16,67 & & - & 4 & 16,67 & 3 & 12,50 & 4 & 16,67 & 1 & 4,17 & & - & & - \\
\hline bicheiras & & - & & - & & - & & - & & - & & - & & - & & - \\
\hline segregação do concreto & & - & 4 & 16,67 & 2 & 8,33 & 1 & 4,17 & 2 & 8,33 & & - & 3 & 12,50 & 3 & 12,50 \\
\hline falta de cobrimento de proteção das armaduras & 5 & 20,83 & 7 & 29,17 & 7 & 29,17 & 13 & 54,17 & 9 & 37,50 & 12 & 50,00 & 15 & 62,50 & 13 & 54,17 \\
\hline efeito parede & & - & & - & & - & & - & & - & & - & & - & & - \\
\hline falta de alinhamento horizontal ou vertical & 10 & 41,67 & 8 & 33,33 & 9 & 37,50 & 6 & 25,00 & 8 & 33,33 & 8 & 33,33 & 9 & 37,50 & 4 & 16,67 \\
\hline carbonatação na superfície de concreto & 1 & 4,17 & & - & & - & 1 & 4,17 & & - & 3 & 12,50 & & - & & - \\
\hline manchas de corrosão ou armadura corroída & 5 & 20,83 & 6 & 25,00 & 10 & 41,67 & 12 & 50,00 & 11 & 45,83 & 14 & 58,33 & 16 & 66,67 & 13 & 54,17 \\
\hline fissuras de retração & & - & & - & & - & & - & & - & & - & & - & & - \\
\hline fissuras inclinadas & & - & & - & & - & & - & & - & & - & & - & & - \\
\hline fissuras em tubulação & & - & & - & & - & & - & & - & & - & & - & & - \\
\hline fissuras verticais & & - & & - & & - & & - & & - & & - & & - & & - \\
\hline deformação das fôrmas & 1 & 4,17 & 6 & 25,00 & 9 & 37,50 & 11 & 45,83 & 9 & 37,50 & 7 & 29,17 & 4 & 16,67 & 1 & 4,17 \\
\hline reparos nos el. estrut. devido segregaçōes & & - & & - & & - & & - & & - & & - & & - & & - \\
\hline lixiviaçäo & 1 & 4,17 & & - & & - & 1 & 4,17 & & - & 3 & 12,50 & & - & & - \\
\hline eflorescências & 1 & 4,17 & & - & & - & 1 & 4,17 & & - & 3 & 12,50 & & - & & - \\
\hline falta de vibração & & - & & - & & - & & - & & - & & - & & - & & - \\
\hline desagregação do concreto & & - & & - & & - & & - & & - & & - & & - & & - \\
\hline mal posicionamento de armadura & & - & 1 & 4,17 & & - & 1 & 4,17 & & - & & - & & - & & - \\
\hline
\end{tabular}


Número de elementos estruturais (pilar) por pavimento $=26$

@ = número de manifestações patológicas por pavimento

$\%=$ porcentagem de manifestações patológicas por pavimento

\begin{tabular}{|c|c|c|c|c|c|c|c|c|c|c|c|c|c|c|}
\hline \multirow{2}{*}{$\begin{array}{l}\text { PAVIMENTO } \\
\text { Tipo de manifestação patológica observada }\end{array}$} & \multicolumn{2}{|c|}{ Térreo } & \multicolumn{2}{|c|}{$1^{\circ}$ pavimento } & \multicolumn{2}{|c|}{$2^{\circ}$ pavimento } & \multicolumn{2}{|c|}{$3^{\circ}$ pavimento } & \multicolumn{2}{|c|}{$4^{\circ}$ pavimento } & \multicolumn{2}{|c|}{$5^{\circ}$ pavimento } & \multicolumn{2}{|c|}{$6^{\circ}$ pavimento } \\
\hline & @ & $\%$ & @ & $\%$ & @ & $\%$ & @ & $\%$ & @ & $\%$ & @ & $\%$ & @ & $\%$ \\
\hline desaprumo & & - & & - & & - & & - & & - & & - & & - \\
\hline torção da fôrma & & - & & - & & - & 1 & 3,85 & 1 & 3,85 & & - & & - \\
\hline junta de concretagem & & - & & - & & - & & - & & - & & - & & - \\
\hline falta de limpeza das fôrmas & & - & & - & & - & 1 & 3,85 & & - & & - & & - \\
\hline falta de estanqueidade das fôrmas & & - & & - & & - & & - & & - & & - & & - \\
\hline falta de limpeza nos elementos estruturais & & - & & - & & - & & - & & - & & - & & - \\
\hline disgregação & 2 & 7,69 & 5 & 19,23 & 3 & 11,54 & 4 & 15,38 & & - & & - & 4 & 15,38 \\
\hline bicheiras & & - & & - & & - & 3 & 11,54 & & - & 1 & 3,85 & 1 & 3,85 \\
\hline segregação do concreto & 1 & 3,85 & 2 & 7,69 & 2 & 7,69 & 2 & 7,69 & 5 & 19,23 & 9 & 34,62 & 2 & 7,69 \\
\hline falta de cobrimento de proteção das armaduras & 4 & 15,38 & 12 & 46,15 & 9 & 34,62 & 5 & 19,23 & 1 & 3,85 & 1 & 3,85 & 5 & 19,23 \\
\hline efeito parede & & - & & - & & - & & - & & - & & - & & - \\
\hline falta de alinhamento horizontal ou vertical & & - & 3 & 11,54 & 7 & 26,92 & 3 & 11,54 & 1 & 3,85 & 1 & 3,85 & 2 & 7,69 \\
\hline carbonatação na superfície de concreto & 20 & 76,92 & 25 & 96,15 & 26 & 100,00 & 26 & 100,00 & 26 & 100,00 & 26 & 100,00 & 26 & 100,00 \\
\hline manchas de corrosão ou armadura corroída & 5 & 19,23 & 13 & 50,00 & 9 & 34,62 & 7 & 26,92 & 1 & 3,85 & 1 & 3,85 & 9 & 34,62 \\
\hline fissuras de retração & & - & & - & & - & & - & & - & & - & & - \\
\hline fissuras inclinadas & & - & & - & & - & & - & & - & & - & & - \\
\hline fissuras em tubulação & & - & & - & & - & & - & & - & & - & & - \\
\hline fissuras verticais & & - & & - & & - & & - & & - & & - & & - \\
\hline deformação das formas & & - & & - & & - & 1 & 3,85 & 1 & 3,85 & 1 & 3,85 & 3 & 11,54 \\
\hline reparos nos el. estrut. devido segregaçōes & & - & 1 & 3,85 & 1 & 3,85 & & - & 2 & 7,69 & 2 & 7,6 & & - \\
\hline lixiviação & & - & & - & & - & 1 & 3,85 & & - & & - & & - \\
\hline eflorescências & & - & & - & & - & 1 & 3,85 & & - & & - & & - \\
\hline falta de vibração & & - & & - & & - & & - & & - & & - & & - \\
\hline desagregação do concreto & & - & & - & & - & & - & & - & & - & & - \\
\hline mal posicionamento de armadura & & & 1 & 3,85 & & - & & - & & - & & - & & - \\
\hline
\end{tabular}




\section{Elemento estrutural - PILAR}

Número de elementos estruturais (pilar) por pavimento $=26$

Q = número de manifestações patológicas por pavimento

$\%=$ porcentagem de manifestações patológicas por pavimento

\begin{tabular}{|c|c|c|c|c|c|c|c|c|c|c|c|c|c|c|c|c|}
\hline \multirow{2}{*}{$\begin{array}{l}\text { PAVIMENTO } \\
\text { Tipo de manifestação patológica observada }\end{array}$} & \multicolumn{2}{|c|}{$7^{\circ}$ pavimento } & \multicolumn{2}{|c|}{$8^{\circ}$ pavimento } & \multicolumn{2}{|c|}{$9^{\circ}$ pavimento } & \multicolumn{2}{|c|}{$10^{\circ}$ pavimento } & \multicolumn{2}{|c|}{$11^{\circ}$ pavimento } & \multicolumn{2}{|c|}{$12^{\circ}$ pavimento } & \multicolumn{2}{|c|}{$13^{\circ}$ pavimento } & \multicolumn{2}{|c|}{$14^{\circ}$ pavimento } \\
\hline & (Q) & $\%$ & @ & $\%$ & @ & $\%$ & @ & $\%$ & @ & $\%$ & @ & $\%$ & $@$ & $\%$ & @ & $\%$ \\
\hline desaprumo & 1 & 3,85 & & - & & - & & - & & - & & - & & - & 1 & 3,85 \\
\hline torção da forma & & - & & - & & - & & - & & - & & - & & - & & - \\
\hline junta de concretagem & & - & & - & & - & & - & & - & & - & & - & & - \\
\hline falta de limpeza das formas & & - & & - & & - & & - & & - & & - & & - & & - \\
\hline falta de estanqueidade das fôrmas & & - & & - & & - & & - & & - & & - & & - & & - \\
\hline falta de limpeza nos elementos estruturais & & - & & - & & - & & - & & - & & - & & - & 12 & 46,15 \\
\hline disgregação & & - & & - & & - & & - & & - & & - & & - & & - \\
\hline bicheiras & & - & 2 & 7,69 & 4 & 15,38 & 1 & 3,85 & 7 & 26,92 & 1 & 3,85 & 5 & 19,23 & 4 & 15,38 \\
\hline segregação do concreto & 6 & 23,08 & 5 & 19,23 & 8 & 30,77 & 10 & 38,46 & 12 & 46,15 & 12 & 46,15 & 11 & 42,31 & 8 & 30,77 \\
\hline falta de cobrimento de proteção das armaduras & 2 & 7,69 & 3 & 11,54 & 2 & 7,69 & 1 & 3,85 & 6 & 23,08 & 3 & 11,54 & 3 & 11,54 & 2 & 7,69 \\
\hline efeito parede & & - & & - & & - & & - & & - & & - & & - & & - \\
\hline falta de alinhamento horizontal ou vertical & & - & & - & & - & & - & & - & & - & 2 & 7,69 & & - \\
\hline carbonatação na superficie de concreto & & - & & - & & - & & - & & - & & - & & - & & - \\
\hline manchas de corrosão ou armadura corroída & & - & 1 & 3,85 & 2 & 7,69 & 1 & 3,85 & 6 & 23,08 & 3 & 11,54 & 2 & 7,69 & 1 & 3,85 \\
\hline fissuras de retração & & - & & - & & - & & - & & - & & - & & - & & - \\
\hline fissuras inclinadas & & - & & - & & - & & - & & - & & - & & - & & - \\
\hline fissuras em tubulação & & - & & - & & - & & - & & - & & - & & - & & - \\
\hline fissuras verticais & & - & & - & & - & & - & & - & & - & & - & & - \\
\hline deformação das fôrmas & 1 & 3,85 & 2 & 7,69 & 2 & 7,69 & 3 & 11,54 & 3 & 11,54 & & - & & - & & - \\
\hline reparos nos el. estrut. devido segregaçōes & & - & & - & & - & & - & & - & 2 & 7,69 & & - & 8 & 30,77 \\
\hline lixiviaçäo & & - & & - & & - & & - & & - & & - & & - & & - \\
\hline eflorescências & & - & & - & & - & & - & & - & & - & & - & & - \\
\hline falta de vibração & & - & & - & & - & & - & & - & & - & & - & & - \\
\hline desagregação do concreto & & - & & - & & - & & - & & - & & - & & - & & - \\
\hline mal posicionamento da armadura & & - & & - & 2 & 7,69 & 1 & 3,85 & 2 & 7,69 & 1 & 3,85 & & - & & - \\
\hline
\end{tabular}


ANEXO H - Tabelas quantitativas das ocorrências de cada elemento estrutural do Edifício $\mathrm{H}$ 
Número de elementos estruturais (laje) por pavimento $=17$

Elemento estrutural - LAJE

@ = número de manifestaçőes patológicas por pavimento

$\%$ = porcentagem de manifestações patológicas por pavimento

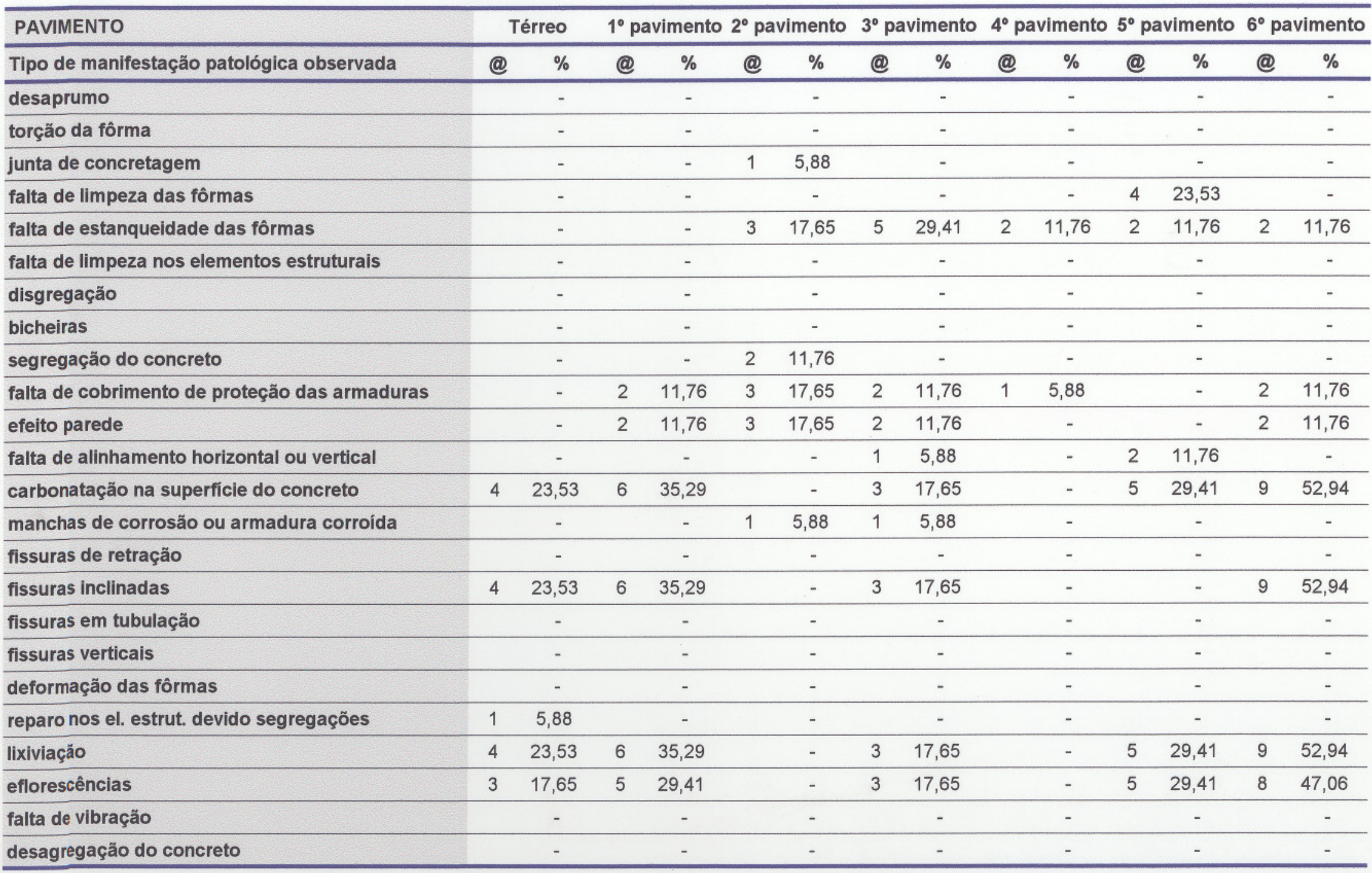


Elemento estrutural - LAJE

Número de elementos estruturais ( laje ) por pavimento $=17$

@ = número de manifestações patológicas por pavimento

$\%=$ porcentagem de manifestações patológicas por pavimento

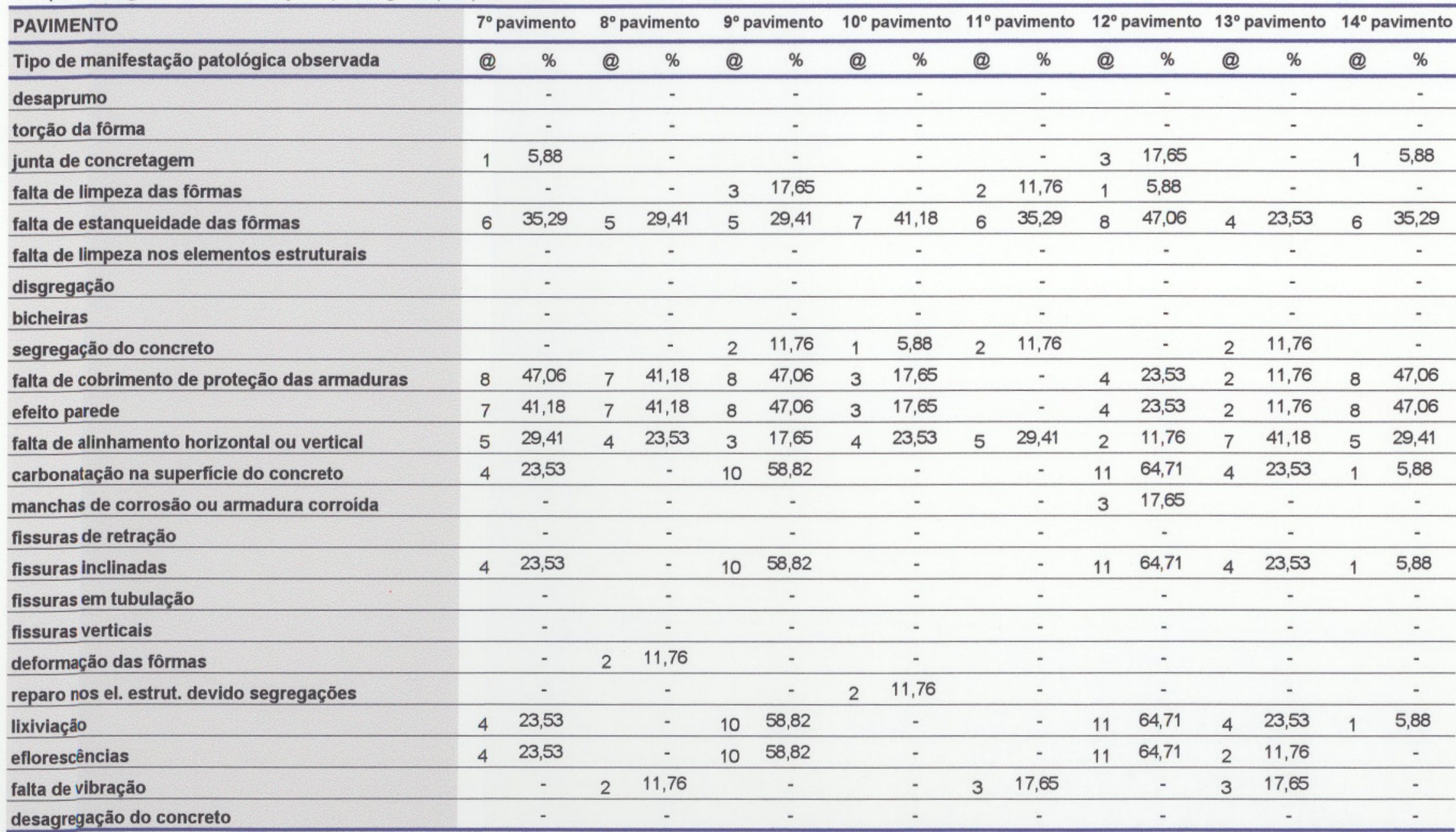


Elemento estrutural - LAJE

Número de elementos estruturais ( laje ) por pavimento $=17$

@ = número de manifestações patológicas por pavimento

$\%=$ porcentagem de manifestações patológicas por pavimento

\begin{tabular}{|c|c|c|c|c|c|c|c|c|c|c|c|c|}
\hline \multirow{2}{*}{$\begin{array}{l}\text { PAVIMENTO } \\
\text { Tipo de manifestação patológica observada }\end{array}$} & \multicolumn{2}{|c|}{$15^{\circ}$ pavimento } & \multicolumn{2}{|c|}{$16^{\circ}$ pavimento } & \multicolumn{2}{|c|}{$17^{\circ}$ pavimento } & \multicolumn{2}{|c|}{$18^{\circ}$ pavimento } & \multicolumn{2}{|c|}{$19^{\circ}$ pavimento } & \multicolumn{2}{|c|}{$20^{\circ}$ pavimento } \\
\hline & @ & $\%$ & @ & $\%$ & @ & $\%$ & @ & $\%$ & @ & $\%$ & @ & $\%$ \\
\hline desaprumo & & - & & - & & - & & - & & - & & - \\
\hline torção da fôrma & & - & & - & & - & & - & & - & & - \\
\hline junta de concretagem & & - & 2 & 11,76 & & - & & - & 3 & 17,65 & & - \\
\hline falta de limpeza das fôrmas & & - & & - & 1 & 5,88 & & - & 2 & 11,76 & 4 & 23,53 \\
\hline falta de estanqueidade das fôrmas & 12 & 70,59 & 8 & 47,06 & 14 & 82,35 & 11 & 64,71 & 10 & 58,82 & 8 & 47,06 \\
\hline falta de limpeza nos elementos estruturais & & - & 5 & 29,41 & 3 & 17,65 & 8 & 47,06 & 6 & 35,29 & 10 & 58,82 \\
\hline disgregação & & - & & - & & - & & - & & - & & - \\
\hline bicheiras & & - & & - & & - & & - & & - & & - \\
\hline segregaçāo do concreto & 2 & 11,76 & & - & 1 & 5,88 & 1 & 5,88 & 4 & 23,53 & 3 & 17,65 \\
\hline falta de cobrimento de proteção das armaduras & 4 & 23,53 & 5 & 29,41 & 7 & 41,18 & 3 & 17,65 & 3 & 17,65 & 3 & 17,65 \\
\hline efeito parede & 4 & 23,53 & 5 & 29,41 & 6 & 35,29 & 2 & 11,76 & 3 & 17,65 & 3 & 17,65 \\
\hline falta de alinhamento horizontal ou vertical & 7 & 41,18 & 3 & 17,65 & 6 & 35,29 & 3 & 17,65 & 8 & 47,06 & 7 & 41,18 \\
\hline carbonatação na superficie do concreto & 15 & 88,24 & 7 & 41,18 & 16 & 94,12 & 14 & 82,35 & 6 & 35,29 & 15 & 88,24 \\
\hline manchas de corrosão ou armadura corroída & & - & & - & 5 & 29,41 & 4 & 23,53 & & - & 2 & 11,76 \\
\hline fissuras de retração & & - & & - & & - & & - & & - & & - \\
\hline fissuras inclinadas & 15 & 88,24 & 7 & 41,18 & 16 & 94,12 & 14 & 82,35 & 6 & 35,29 & 15 & 88,24 \\
\hline fissuras em tubulação & & - & & - & & - & & - & & - & & - \\
\hline fissuras verticais & & - & & - & & - & & - & & - & & - \\
\hline deformação das fôrmas & 3 & 17,65 & & - & 7 & 41,18 & 5 & 29,41 & 5 & 29,41 & 8 & 47,06 \\
\hline reparo nos el. estrut. devido segregações & & - & & - & & - & & - & & - & & - \\
\hline lixiviaçăo & 15 & 88,24 & 7 & 41,18 & 16 & 94,12 & 14 & 82,35 & 6 & 35,29 & 15 & 88,24 \\
\hline eflorescências & 15 & 88,24 & 7 & 41,18 & 16 & 94,12 & 14 & 82,35 & 5 & 29,41 & 14 & 82,35 \\
\hline falta de vibração & 2 & 11,76 & & - & 1 & 5,88 & 5 & 29,41 & & - & 2 & 11,76 \\
\hline desagregação do concreto & & - & & - & & - & & - & & - & & - \\
\hline
\end{tabular}




\section{Elemento estrutural - VIGA}

Número de elementos estruturais (viga) por pavimento $=41$

@ = número de manifestações patológicas por pavimento

$\%=$ porcentagem de manifestações patológicas por pavimento

\begin{tabular}{|c|c|c|c|c|c|c|c|c|c|c|c|c|c|c|}
\hline PAVIMENTO & & érreo & $1^{\circ} \mathrm{pa}$ & vimento & $2^{\circ} \mathrm{pa}$ & vimento & $3^{\circ} \mathrm{pa}$ & vimento & $4^{\circ} \mathrm{pe}$ & ivimento & $5^{\circ} \mathrm{p}$ & vimento & $6^{\circ} \mathrm{pa}$ & vimento \\
\hline Tipo de manifestação patológica observada & @ & $\%$ & @ & $\%$ & @ & $\%$ & @ & $\%$ & @ & $\%$ & @ & $\%$ & (1) & $\%$ \\
\hline desaprumo & & - & & - & & - & & - & & - & & - & & - \\
\hline torção da fôrma & & - & & - & & - & & - & 3 & 7,32 & & - & 5 & 12,20 \\
\hline junta de concretagem & & - & & - & 1 & 2,44 & & - & & - & & - & & - \\
\hline falta de limpeza das fôrmas & & - & & - & 3 & 7,32 & 1 & 2,44 & & - & 2 & 4,88 & & - \\
\hline falta de estanqueidade das fôrmas & 6 & 14,63 & 1 & 2,44 & 8 & 19,51 & 4 & 9,76 & 12 & 29,27 & 20 & 48,78 & 13 & 31,71 \\
\hline falta de limpeza nos elementos estruturais & & - & & - & & - & & - & 2 & 4,88 & & - & & - \\
\hline disgregação & 13 & 31,71 & 12 & 29,27 & 13 & 31,71 & 10 & 24,39 & 11 & 26,83 & 5 & 12,20 & & - \\
\hline bicheiras & & - & & - & & - & & - & & - & & - & 1 & 2,44 \\
\hline segregação do concreto & & - & & - & & - & & - & 2 & 4,88 & 1 & 2,44 & & - \\
\hline falta de cobrimento de proteção das armaduras & 26 & 63,41 & 27 & 65,85 & 20 & 48,78 & 22 & 53,66 & 26 & 63,41 & 30 & 73,17 & 32 & 78,05 \\
\hline efeito parede & & - & & - & & - & & - & & - & & - & & - \\
\hline falta de alinhamento horizontal ou vertical & & - & 1 & 2,44 & 3 & 7,32 & & - & 4 & 9,76 & & - & 3 & 7,32 \\
\hline carbonatação na superfície do concreto & & - & & - & & - & & - & 1 & 2,44 & & - & & - \\
\hline manchas de corrosão ou armadura corroída & 10 & 24,39 & 7 & 17,07 & 5 & 12,20 & 1 & 2,44 & & - & 3 & 7,32 & & - \\
\hline fissuras de retração & & - & & - & & - & & - & & - & & - & & - \\
\hline fissuras inclinadas & & - & & - & & - & & - & & - & & - & & - \\
\hline fissuras em tubulação & & - & & - & 2 & 4,88 & & - & & - & & - & 5 & 12,20 \\
\hline fissuras verticais & & - & & - & 1 & 2,44 & 2 & 4,88 & & - & & - & & - \\
\hline deformação das fôrmas & & - & & - & 4 & 9,76 & & - & 5 & 12,20 & 7 & 17,07 & 3 & 7,32 \\
\hline reparo nos el. estrut. devido segregações & & - & & - & & - & & - & & - & & - & & - \\
\hline lixiviaçắo & & - & & - & & - & & - & 1 & 2,44 & & - & & - \\
\hline eflorescências & & - & & - & & - & & - & & - & & - & & - \\
\hline falta de vibração & & - & & - & & - & & - & & - & & - & & - \\
\hline desagregação do concreto & & - & & - & & - & & - & & - & & - & & - \\
\hline
\end{tabular}


Elemento estrutural - VIGA

Número de elementos estruturais (viga) por pavimento $=41$

@ = número de manifestações patológicas por pavimento

$\%=$ porcentagem de manifestaçőes patológicas por pavimento

\begin{tabular}{|c|c|c|c|c|c|c|c|c|c|c|c|c|c|c|c|c|}
\hline \multirow{2}{*}{$\begin{array}{l}\text { PAVIMENTO } \\
\text { Tipo de manifestação patológica observada }\end{array}$} & \multicolumn{2}{|c|}{$7^{\circ}$ pavimento } & \multicolumn{2}{|c|}{$8^{\circ}$ pavimento } & \multicolumn{2}{|c|}{$9^{\circ}$ pavimento } & \multicolumn{2}{|c|}{$10^{\circ}$ pavimento } & \multicolumn{2}{|c|}{$11^{\circ}$ pavimento } & \multicolumn{2}{|c|}{$12^{\circ}$ pavimento } & \multicolumn{2}{|c|}{$13^{\circ}$ pavimento } & \multicolumn{2}{|c|}{$14^{\circ}$ pavimento } \\
\hline & $@$ & $\%$ & @ & $\%$ & $@$ & $\%$ & @ & $\%$ & @ & $\%$ & @ & $\%$ & $@$ & $\%$ & $@$ & $\%$ \\
\hline desaprumo & & - & & - & & - & & - & & - & & - & & - & & - \\
\hline torção da fôrma & & - & & - & & - & & - & & - & & - & & - & 6 & 14,63 \\
\hline junta de concretagem & & - & & - & & - & & - & 2 & 4,88 & & - & & - & 1 & 2,44 \\
\hline falta de limpeza das fôrmas & & - & & - & & - & & - & 5 & 12,20 & & - & 3 & 7,32 & & - \\
\hline falta de estanqueidade das fôrmas & 15 & 36,59 & 11 & 26,83 & 30 & 73,17 & 21 & 51,22 & & - & & - & & - & 22 & 53,66 \\
\hline falta de limpeza nos elementos estruturais & & - & & - & & - & & - & & - & & - & & - & & - \\
\hline disgregaçāo & & - & 6 & 14,63 & & - & 2 & 4,88 & & - & & - & & - & & - \\
\hline bicheiras & & - & & - & & - & & - & 3 & 7,32 & & - & & - & & - \\
\hline segregação do concreto & 2 & 4,88 & & - & 1 & 2,44 & 3 & 7,32 & & - & 6 & 14,63 & 2 & 4,88 & 5 & 12,20 \\
\hline falta de cobrimento de proteção das armaduras & 19 & 46,34 & 30 & 73,17 & 25 & 60,98 & 20 & 48,78 & 27 & 65,85 & 31 & 75,61 & 19 & 46,34 & 12 & 29,27 \\
\hline efeito parede & & - & & - & & - & & - & & - & & - & & - & & - \\
\hline falta de alinhamento horizontal ou vertical & & - & 5 & 12,20 & 7 & 17,07 & & - & 4 & 9,76 & 9 & 21,95 & 10 & 24,39 & 9 & 21,95 \\
\hline carbonatação na superfície do concreto & & - & & - & & - & & - & & - & & - & & - & & - \\
\hline manchas de corrosão ou armadura corroída & 3 & 7,32 & & - & & - & 5 & 12,20 & & - & & - & & - & & - \\
\hline fissuras de retração & & - & & - & & - & & - & & - & & - & & - & 5 & 12,20 \\
\hline fissuras inclinadas & & - & & - & & - & & - & & - & & - & & - & & - \\
\hline fissuras em tubulação & 8 & 19,51 & 3 & 7,32 & 7 & 17,07 & 1 & 2,44 & 6 & 14,63 & & - & 8 & 19,51 & & - \\
\hline fissuras verticais & & - & & - & & - & & - & & - & & - & & - & 2 & 4,88 \\
\hline deformação das fôrmas & 8 & 19,51 & 16 & 39,02 & 21 & 51,22 & 19 & 46,34 & 5 & 12,20 & 9 & 21,95 & 15 & 36,59 & 12 & 29,27 \\
\hline reparo nos el. estrut. devido segregaçōes & & - & & - & & - & & - & 1 & 2,44 & & - & 3 & 7,32 & & - \\
\hline lixiviaçáa & & - & & - & & - & & - & & - & & - & & - & & - \\
\hline eflorescências & & - & & - & & - & & - & & - & & - & & - & & - \\
\hline falta de vibraçāo & & - & & - & & - & & - & & - & & - & & - & & - \\
\hline desagregação do concreto & & - & & - & & - & & - & & - & & - & & - & & - \\
\hline
\end{tabular}


Número de elementos estruturais (viga) por pavimento $=41$

$@=$ número de manifestações patológicas por pavimento

$\%=$ porcentagem de manifestações patológicas por pavimento

\begin{tabular}{|c|c|c|c|c|c|c|c|c|c|c|c|c|}
\hline \multirow{2}{*}{$\begin{array}{l}\text { PAVIMENTO } \\
\text { Tipo de manifestação patológica observada }\end{array}$} & \multicolumn{2}{|c|}{$15^{\circ}$ pavimento } & \multicolumn{2}{|c|}{$16^{\circ}$ pavimento } & \multicolumn{2}{|c|}{$17^{\circ}$ pavimento } & \multicolumn{2}{|c|}{$18^{\circ}$ pavimento } & \multicolumn{2}{|c|}{$19^{\circ}$ pavimento } & \multicolumn{2}{|c|}{$20^{\circ}$ pavimento } \\
\hline & @ & $\%$ & @ & $\%$ & @ & $\%$ & @ & $\%$ & @ & $\%$ & @ & $\%$ \\
\hline desaprumo & & - & & - & & - & & - & & - & & - \\
\hline torção da fôrma & & - & & - & & - & & - & & - & & - \\
\hline junta de concretagem & 2 & 4,88 & & - & & - & 3 & 7,32 & & - & 1 & 2,44 \\
\hline falta de limpeza das formas & & - & 6 & 14,63 & & - & 2 & 4,88 & 9 & 21,95 & 5 & 12,20 \\
\hline falta de estanqueidade das fôrmas & & - & 10 & 24,39 & 22 & 53,66 & 23 & 56,10 & 24 & 58,54 & 20 & 48,78 \\
\hline falta de limpeza nos elementos estruturais & & - & & - & & - & & - & & - & 3 & 7,32 \\
\hline disgregação & & - & & - & & - & & - & & - & & - \\
\hline bicheiras & & - & & - & & - & & - & & - & & - \\
\hline segregação do concreto & 1 & 2,44 & & - & 3 & 7,32 & 1 & 2,44 & & - & 4 & 9,76 \\
\hline falta de cobrimento de proteção das armaduras & 25 & 60,98 & 23 & 56,10 & 31 & 75,61 & 33 & 80,49 & 24 & 58,54 & 20 & 48,78 \\
\hline efeito parede & & - & & - & & - & & - & & - & & - \\
\hline falta de alinhamento horizontal ou vertical & & - & 7 & 17,07 & 9 & 21,95 & 6 & 14,63 & & - & 5 & 12,20 \\
\hline carbonatação na superficie do concreto & & - & & - & & - & & - & & - & & - \\
\hline manchas de corrosão ou armadura corroída & & - & & - & & - & & - & & - & & - \\
\hline fissuras de retração & & - & & - & & - & & - & & - & & - \\
\hline fissuras inclinadas & & - & & - & & - & & - & & - & & - \\
\hline fissuras em tubulação & 2 & 4,88 & 3 & 7,32 & & - & 8 & 19,51 & & - & 6 & 14,63 \\
\hline fissuras verticais & & - & 5 & 12,20 & 4 & 9,76 & 5 & 12,20 & 1 & 2,44 & 8 & 19,51 \\
\hline deformação das fôrmas & 22 & 53,66 & 17 & 41,46 & 19 & 46,34 & 15 & 36,59 & 10 & 24,39 & 10 & 24,39 \\
\hline reparos nos e.e devido segregaçōes & & - & & - & & - & & - & & - & & - \\
\hline lixiviaçăo & & - & & - & & - & & - & & - & & - \\
\hline eflorescências & & - & & - & & - & & - & & - & & - \\
\hline falta de vibração & & - & & - & & - & & - & & - & & - \\
\hline desagregação do concreto & & - & & - & & - & & - & & - & & - \\
\hline
\end{tabular}




\section{Elemento estrutural - PILAR}

Número de elementos estruturais (pilar) por pavimento $=6$

@ = número de manifestações patológicas por pavimento

$\%=$ porcentagem de manifestações patológicas por pavimento

\begin{tabular}{|c|c|c|c|c|c|c|c|c|c|c|c|c|c|c|}
\hline PAVIMENTO & & érreo & $1^{\circ} \mathrm{p}$ & vimento & $2^{\circ} \mathrm{pa}$ & vimento & $3^{\circ} \mathrm{p}$ & avimento & $4^{\circ} \mathrm{p}$ & avimento & $5^{\circ} \mathrm{pe}$ & avimento & $6^{\circ} \mathrm{p}$ & vimento \\
\hline Tipo de manifestação patológica observada & @ & $\%$ & (C) & $\%$ & @ & $\%$ & @ & $\%$ & @ & $\%$ & (C) & $\%$ & (Q) & $\%$ \\
\hline desaprumo & & - & & - & & - & & - & & - & & - & & - \\
\hline torção da fôrma & & - & & - & & - & & - & & - & & - & & - \\
\hline junta de concretagem & & - & & - & & - & & - & & - & & - & & - \\
\hline falta de limpeza das fôrmas & 1 & 16,67 & & - & & - & & - & & - & & - & & - \\
\hline falta de estanqueidade das fôrmas & & - & & - & & - & & - & & - & & - & & - \\
\hline falta de limpeza nos elementos estruturais & & - & & - & & - & & - & & - & & - & & - \\
\hline disgregação & & - & & - & & - & & - & & - & & - & & - \\
\hline bicheiras & & - & & - & & - & & - & & - & & - & & - \\
\hline segregação do concreto & & - & & - & & - & 1 & 16,67 & 2 & 33,33 & & - & & - \\
\hline falta de cobrimento de proteção das armaduras & & - & 1 & 16,67 & 2 & 33,33 & & - & & - & & - & & - \\
\hline efeito parede & & - & & - & & - & & - & & - & & - & & - \\
\hline falta de alinhamento horizontal ou vertical & & - & & - & & - & & - & & - & 2 & 33,33 & 2 & 33,33 \\
\hline carbonatação na superficie do concreto & & - & & - & & - & & - & & - & & - & & - \\
\hline manchas de corrosão ou armadura corroída & & - & & - & & - & & - & & - & & - & & - \\
\hline fissuras de retração & & - & & - & & - & & - & & - & & - & & - \\
\hline fissuras inclinadas & & - & & - & & - & & - & & - & & - & & - \\
\hline fissuras em tubulação & & - & & - & & - & & - & & - & & - & & - \\
\hline fissuras verticais & & - & & - & & - & & - & & - & & - & & - \\
\hline deformação das fôrmas & & - & & - & & - & & - & & - & 1 & 16,67 & 2 & 33,33 \\
\hline reparo nos el. estrut. devido segregações & & - & & - & & - & & - & & - & & - & & - \\
\hline lixiviaçăo & & - & & - & & - & & - & & - & & - & & - \\
\hline eflorescências & & - & & - & & - & & - & & - & & - & & - \\
\hline falta de vibração & & - & & - & & - & & - & & - & & - & & - \\
\hline desagregação do concreto & & - & & - & & - & & - & & - & & - & & - \\
\hline
\end{tabular}


Número de elementos estruturais (pilar) por pavimento $=6$

@ = número de manifestações patológicas por pavimento

$\%=$ porcentagem de manifestações patológicas por pavimento

\begin{tabular}{|c|c|c|c|c|c|c|c|c|c|c|c|c|c|c|c|c|}
\hline \multirow{2}{*}{$\begin{array}{l}\text { PAVIMENTO } \\
\text { Tipo de manifestação patológica observada }\end{array}$} & \multicolumn{2}{|c|}{$7^{\circ}$ pavimento } & \multicolumn{2}{|c|}{$8^{\circ}$ pavimento } & \multicolumn{2}{|c|}{$9^{\circ}$ pavimento } & \multicolumn{2}{|c|}{$10^{\circ}$ pavimento } & \multicolumn{2}{|c|}{$11^{\circ}$ pavimento } & \multicolumn{2}{|c|}{$12^{\circ}$ pavimento } & \multicolumn{2}{|c|}{$13^{\circ}$ pavimento } & \multicolumn{2}{|c|}{$14^{\circ}$ pavimento } \\
\hline & @ & $\%$ & @ & $\%$ & (C) & $\%$ & @ & $\%$ & @ & $\%$ & @ & $\%$ & @ & $\%$ & @ & $\%$ \\
\hline desaprumo & & - & & - & & - & & - & & - & & - & & - & & - \\
\hline torção da fôrma & & - & & - & & - & & - & & - & & - & & - & & - \\
\hline junta de concretagem & & - & & - & & - & & - & & - & & - & & - & & - \\
\hline falta de limpeza das fôrmas & & - & & - & & - & 3 & 50,00 & & - & 1 & 16,67 & & - & 2 & 33,33 \\
\hline falta de estanqueidade das fôrmas & & - & & - & 1 & 16,67 & & - & & - & & - & & - & & - \\
\hline falta de limpeza nos elementos estruturais & & - & 1 & 16,67 & & - & & - & & - & & - & 1 & 16,67 & 3 & 50,00 \\
\hline disgregação & & - & & - & & - & & - & 2 & 33,33 & 3 & 50,00 & & - & & - \\
\hline bicheiras & & - & & - & & - & & - & & - & & - & & - & & - \\
\hline segregação do concreto & 3 & 50,00 & & - & & - & 2 & 33,33 & & - & 3 & 50,00 & & - & 4 & 66,67 \\
\hline falta de cobrimento de proteção das armaduras & & - & & - & 2 & 33,33 & & - & & - & & - & & - & & - \\
\hline efeito parede & & - & & - & & - & & - & & - & & - & & - & & - \\
\hline falta de alinhamento horizontal ou vertical & 3 & 50,00 & & - & 1 & 16,67 & 2 & 33,33 & 1 & 16,67 & 2 & 33,33 & 2 & 33,33 & 3 & 50,00 \\
\hline carbonatação na superfície do concreto & 6 & 100,00 & 6 & 100,00 & 6 & 100,00 & 6 & 100,00 & 6 & 100,00 & 6 & 100,00 & 6 & 100,00 & 6 & 100,00 \\
\hline manchas de corrosão ou armadura corroída & & - & & - & & - & & - & & - & & - & & - & 2 & 33,33 \\
\hline fissuras de retração & & - & & - & & - & & - & & - & & - & & - & & - \\
\hline fissuras inclinadas & & - & & - & & - & & - & & - & & - & & - & & - \\
\hline fissuras em tubulação & & - & & - & & - & & - & & - & & - & & - & & - \\
\hline fissuras verticais & & - & & - & & - & & - & & - & & - & & - & & - \\
\hline deformação das fôrmas & 1 & 16,67 & 2 & 33,33 & 2 & 33,33 & 3 & 50,00 & 3 & 50,00 & 2 & 33,33 & 2 & 33,33 & 3 & 50,00 \\
\hline reparo nos el. estrut. devido segregaçōes & & - & & - & & - & & - & & - & 1 & 16,67 & & - & 3 & 50,00 \\
\hline lixiviaçăo & & - & & - & & - & & - & & - & & - & & - & & - \\
\hline eflorescências & & - & & - & & - & & - & & - & & - & & - & & - \\
\hline falta de vibraçäo & & - & & - & & - & & - & & - & & - & & - & & - \\
\hline desagregação do concreto & & - & & - & & - & & - & & - & & - & & - & & - \\
\hline
\end{tabular}


Elemento estrutural - PILAR

Número de elementos estruturais (pilar) por pavimento $=6$

Q = número de manifestações patológicas por pavimento

$\%=$ porcentagem de manifestações patológicas por pavimento

\begin{tabular}{|c|c|c|c|c|c|c|c|c|c|c|c|c|}
\hline \multirow{2}{*}{$\begin{array}{l}\text { PAVIMENTO } \\
\text { Tipo de manifestação patológica observada }\end{array}$} & \multicolumn{2}{|c|}{$15^{\circ}$ pavimento } & \multicolumn{2}{|c|}{$16^{\circ}$ pavimento } & \multicolumn{2}{|c|}{$17^{\circ}$ pavimento } & \multicolumn{2}{|c|}{$18^{\circ}$ pavimento } & \multicolumn{2}{|c|}{$19^{\circ}$ pavimento } & \multicolumn{2}{|c|}{$20^{\circ}$ pavimento } \\
\hline & $@$ & $\%$ & @ & $\%$ & @ & $\%$ & @ & $\%$ & @ & $\%$ & @ & $\%$ \\
\hline desaprumo & & - & & - & & - & & - & & - & & - \\
\hline torção da fôrma & & - & & - & & - & & - & & - & & - \\
\hline junta de concretagem & & - & & - & & - & & - & & - & & - \\
\hline falta de limpeza das fôrmas & 2 & 33,33 & & - & 3 & 50,00 & & - & & - & 5 & 83,33 \\
\hline falta de estanqueidade das fôrmas & & - & & - & & - & & - & & - & & - \\
\hline falta de limpeza nos elementos estruturais & & - & 2 & 33,33 & & - & & - & 2 & 33,33 & & - \\
\hline disgregação & & - & & - & & - & & - & & - & & - \\
\hline bicheiras & & - & 1 & 16,67 & & - & & - & & - & & - \\
\hline segregação do concreto & 1 & 16,67 & 2 & 33,33 & 1 & 16,67 & & - & 2 & 33,33 & 4 & 66,67 \\
\hline falta de cobrimento de proteção das armaduras & & - & & - & 2 & 33,33 & & - & & - & & - \\
\hline efeito parede & & - & & - & & - & & - & & - & & - \\
\hline falta de alinhamento horizontal ou vertical & 1 & 16,67 & 2 & 33,33 & & - & 4 & 66,67 & 3 & 50,00 & 4 & 66,67 \\
\hline carbonatação na superfície do concreto & 6 & 100,00 & 6 & 100,00 & 6 & 100,00 & 6 & 100,00 & 6 & 100,00 & 6 & 100,00 \\
\hline manchas de corrosão ou armadura corroída & 1 & 16,67 & 1 & 16,67 & & - & & - & 2 & 33,33 & & - \\
\hline fissuras de retração & & - & & - & & - & & - & & - & & - \\
\hline fissuras inclinadas & & - & & - & & - & & - & & - & & - \\
\hline fissuras em tubulação & & - & & - & & - & & - & & - & & - \\
\hline fissuras verticais & & - & & - & & - & & - & & - & & - \\
\hline deformação das fôrmas & 4 & 66,67 & 2 & 33,33 & 3 & 50,00 & 3 & 50,00 & 5 & 83,33 & 5 & 83,33 \\
\hline reparo nos el. estrut. devido segregações & & - & & - & 2 & 33,33 & 1 & 16,67 & & - & & - \\
\hline lixiviaçäo & & - & & - & & - & & - & & - & & - \\
\hline eflorescências & & - & & - & & - & & - & & - & & - \\
\hline falta de vibração & & - & & - & & - & & - & & - & & - \\
\hline desagregação do concreto & & - & & - & & - & & - & & - & & - \\
\hline
\end{tabular}




\section{Elemento estrutural - PAREDE}

Número de elementos estruturais (parede) por pavimento $=16$

@ = número de manifestações patológicas por pavimento

$\%=$ porcentagem de manifestações patológicas por pavimento

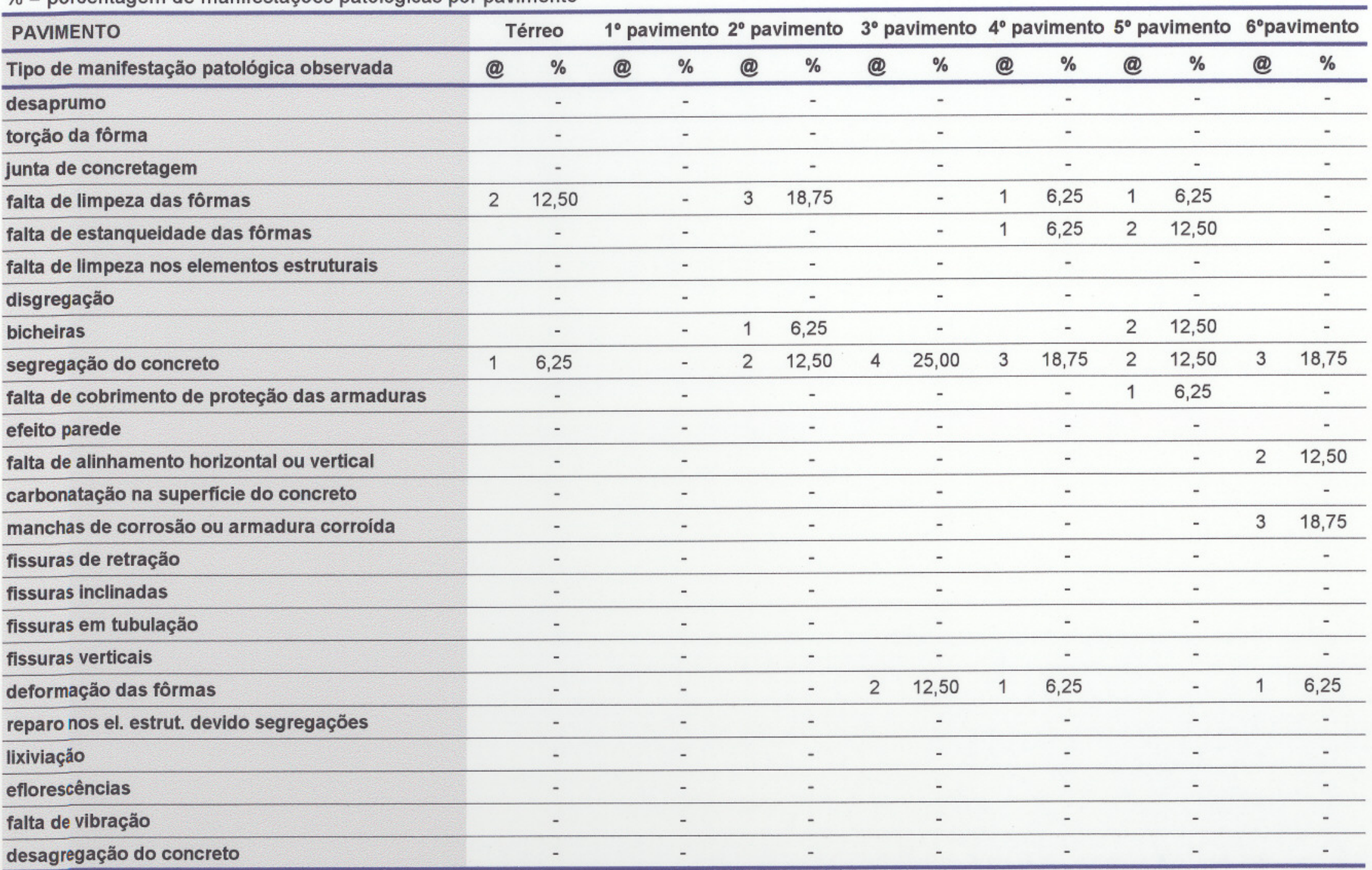




\section{Elemento estrutural - PAREDE}

Número de elementos estruturais ( parede ) por pavimento $=16$

@ = número de manifestações patológicas por pavimento

$\%=$ porcentagem de manifestações patológicas por pavimento

\begin{tabular}{|c|c|c|c|c|c|c|c|c|c|c|c|c|c|c|c|c|}
\hline \multirow{2}{*}{$\begin{array}{l}\text { PAVIMENTO } \\
\text { Tipo de manifestação patológica observada }\end{array}$} & \multicolumn{2}{|c|}{$7^{\circ}$ pavimento } & \multicolumn{2}{|c|}{$8^{\circ}$ pavimento } & \multicolumn{2}{|c|}{$9^{\circ}$ pavimento } & \multicolumn{2}{|c|}{$10^{\circ}$ pavimento } & \multicolumn{2}{|c|}{$11^{\circ}$ pavimento } & \multicolumn{2}{|c|}{$12^{\circ}$ pavimento } & \multicolumn{2}{|c|}{$13^{\circ}$ pavimento } & \multicolumn{2}{|c|}{$14^{\circ}$ pavimento } \\
\hline & @ & $\%$ & @ & $\%$ & @ & $\%$ & @ & $\%$ & @ & $\%$ & @ & $\%$ & @ & $\%$ & @ & $\%$ \\
\hline desaprumo & & - & & - & & - & & - & & - & & - & & - & & - \\
\hline torção da fôrma & & - & & - & & - & & - & & - & & - & & - & & - \\
\hline junta de concretagem & & - & & - & & - & & - & & - & & - & & - & & - \\
\hline falta de limpeza das fôrmas & 6 & 37,50 & & - & 5 & 31,25 & 2 & 12,50 & & - & & - & & - & & - \\
\hline falta de estanqueidade das fôrmas & & - & & - & & - & & - & & - & & - & & - & 3 & 18,75 \\
\hline falta de limpeza nos elementos estruturais & 2 & 12,50 & & - & 3 & 18,75 & 1 & 6,25 & & - & & - & & - & 3 & 18,75 \\
\hline disgregação & & - & & - & & - & & - & & - & & - & & - & & - \\
\hline bicheiras & & - & & - & & - & & - & & - & & - & & - & 1 & 6,25 \\
\hline segregação do concreto & & - & 6 & 37,50 & 4 & 25,00 & 2 & 12,50 & 3 & 18,75 & & - & 3 & 18,75 & 4 & 25,00 \\
\hline falta de cobrimento de proteção das armaduras & & - & 2 & 12,50 & & - & & - & 2 & 12,50 & & - & & - & & - \\
\hline efeito parede & & - & & - & & - & & - & & - & & - & & - & & - \\
\hline falta de alinhamento horizontal ou vertical & 3 & 18,75 & 1 & 6,25 & 1 & 6,25 & 4 & 25,00 & & - & 2 & 12,50 & & - & & - \\
\hline carbonatação na superficie do concreto & & - & & - & & - & & - & & - & & - & & - & & - \\
\hline manchas de corrosão ou armadura corroída & & - & 2 & 12,50 & & - & & - & 2 & 12,50 & & - & & - & & - \\
\hline fissuras de retração & & - & & - & & - & & - & & - & & - & & - & & - \\
\hline fissuras inclinadas & & - & & - & & - & & - & & - & & - & & - & & - \\
\hline fissuras em tubulaçäo & & - & & - & & - & & - & & - & & - & & - & & - \\
\hline fissuras verticais & & - & & - & & - & & - & & - & & - & & - & & - \\
\hline deformação das fôrmas & 3 & 18,75 & 1 & 6,25 & 3 & 18,75 & 2 & 12,50 & 1 & 6,25 & 3 & 18,75 & 2 & 12,50 & 5 & 31,25 \\
\hline reparo nos el. estrut. devido segregaçōes & & - & & - & & - & & - & & - & 2 & 12,50 & 1 & 6,25 & 5 & 31,25 \\
\hline lixiviaçäo & & - & & - & & - & & - & & - & & - & & - & & - \\
\hline eflorescências & & - & & - & & - & & - & & - & & - & & - & & - \\
\hline falta de vibração & & - & & - & & - & & - & & - & & - & & - & & - \\
\hline desagregação do concreto & & - & & - & & - & & - & & - & & - & & - & & - \\
\hline
\end{tabular}




\section{Elemento estrutural - PAREDE}

Número de elementos estruturais ( parede ) por pavimento $=16$

@ = número de manifestações patológicas por pavimento

$\%=$ porcentagem de manifestaçőes patológicas por pavimento

\begin{tabular}{|c|c|c|c|c|c|c|c|c|c|c|c|c|}
\hline PAVIMENTO & $15^{\circ}$ & avimento & $16^{\circ}$ & avimento & $17^{\circ}$ & avimento & $18^{\circ}$ & avimento & $19^{\circ}$ & avimento & $20^{\circ}$ & avimento \\
\hline Tipo de manifestação patológica observada & @ & $\%$ & $@$ & $\%$ & @ & $\%$ & @ & $\%$ & @ & $\%$ & @ & $\%$ \\
\hline desaprumo & & - & & - & & - & & - & & - & & - \\
\hline torção da fôrma & & - & & - & & - & & - & & - & & - \\
\hline junta de concretagem & & - & & - & & - & & - & & - & & - \\
\hline falta de limpeza das fôrmas & 1 & 6,25 & & - & 1 & 6,25 & 2 & 12,50 & & - & 4 & 25,00 \\
\hline falta de estanqueidade das fôrmas & & - & & - & & - & & - & & - & & - \\
\hline falta de limpeza nos elementos estruturais & & - & & - & & - & & - & & - & & - \\
\hline disgregação & & - & & - & & - & & - & & - & & - \\
\hline bicheiras & 1 & 6,25 & & - & & - & 2 & 12,50 & & - & & - \\
\hline segregação do concreto & 3 & 18,75 & 4 & 25,00 & 5 & 31,25 & 6 & 37,50 & 3 & 18,75 & 4 & 25,00 \\
\hline falta de cobrimento de proteção das armaduras & & - & & - & & - & & - & & - & & - \\
\hline efeito parede & & - & & - & & - & & - & & - & & - \\
\hline falta de alinhamento horizontal ou vertical & 2 & 12,50 & 1 & 6,25 & & - & 3 & 18,75 & 2 & 12,50 & 2 & 12,50 \\
\hline carbonatação na superfície do concreto & & - & & - & & - & & - & & - & & - \\
\hline manchas de corrosão ou armadura corroída & 2 & 12,50 & & - & & - & & - & & - & & - \\
\hline fissuras de retraçāo & & - & & - & & - & & - & & - & & - \\
\hline fissuras inclinadas & & - & & - & & - & & - & & - & & - \\
\hline fissuras em tubulação & & - & & - & & - & & - & & - & & - \\
\hline fissuras verticais & & - & & - & & - & & - & & - & & - \\
\hline deformação das fôrmas & 3 & 18,75 & & - & 5 & 31,25 & 3 & 18,75 & 1 & 6,25 & 2 & 12,50 \\
\hline reparo nos el. estrut. devido segregaçōes & & - & & - & & - & & - & & - & & - \\
\hline lixiviação & & - & & - & & - & & - & & - & & - \\
\hline eflorescências & & - & & - & & - & & - & & - & & - \\
\hline falta de vibração & & - & & - & & - & & - & & - & & - \\
\hline desagregação do concreto & & - & & - & & - & & - & & - & & - \\
\hline
\end{tabular}


ANEXO I - Tabelas quantitativas das ocorrências de cada elemento estrutural do Edifício I 
Elemento estrutural - LAJE

Número de elementos estruturais (laje) por pavimento $=10$

@ = número de manifestações patológicas por pavimento

$\%=$ porcentagem de manifestações patológicas por pavimento

\begin{tabular}{|c|c|c|c|c|c|c|c|c|c|c|c|c|}
\hline \multirow{2}{*}{$\begin{array}{l}\text { PAVIMENTO } \\
\text { Tipo de manifestação patológica observada }\end{array}$} & \multicolumn{2}{|c|}{ Térreo } & \multicolumn{2}{|c|}{$1^{\circ}$ pavimento } & \multicolumn{2}{|c|}{$2^{\circ}$ pavimento } & \multicolumn{2}{|c|}{$3^{\circ}$ pavimento } & \multicolumn{2}{|c|}{$4^{\circ}$ pavimento } & \multicolumn{2}{|c|}{$5^{\circ}$ pavimento } \\
\hline & @ & $\%$ & $@$ & $\%$ & @ & $\%$ & $@$ & $\%$ & @ & $\%$ & $@$ & $\%$ \\
\hline desaprumo & & - & & - & & - & & - & & - & & - \\
\hline torção da fôrma & & - & & - & & - & & - & & - & & - \\
\hline junta de concreto & & - & & - & & - & & - & & - & & - \\
\hline falta de limpeza das fôrmas & & - & & - & & - & & - & 1 & 10,00 & & - \\
\hline falta de estanqueidade das fôrmas & & - & & - & 1 & 10,00 & 7 & 70,00 & 10 & 100,00 & 8 & 80,00 \\
\hline falta de limpeza nos elementos estruturais & & - & & - & & - & 2 & 20,00 & 2 & 20,00 & 1 & 10,00 \\
\hline disgregação & & - & & - & & - & & - & & - & & - \\
\hline bicheiras & & - & & - & & - & & - & 2 & 20,00 & & - \\
\hline segregação do concreto & & - & & - & & - & & - & 1 & 10,00 & & - \\
\hline falta de cobrimento de proteção das armaduras & & - & & - & & - & & - & 1 & 10,00 & & - \\
\hline efeito parede & & - & 1 & 10,00 & & - & & - & & - & & - \\
\hline falta de alinhamento horizontal ou vertical & & - & & - & 1 & 10,00 & 3 & 30,00 & 1 & 10,00 & 1 & 10,00 \\
\hline carbonatação na superficie do concreto & 3 & 30,00 & 14 & 140,00 & 3 & 30,00 & 3 & 30,00 & & - & 13 & 130,00 \\
\hline manchas de corrosão ou armadura corroída & & - & 2 & 20,00 & 1 & 10,00 & & - & & - & & - \\
\hline fissuras de retração & & - & & - & & - & & - & & - & & - \\
\hline fissuras inclinadas & 3 & 30,00 & 11 & 110,00 & 4 & 40,00 & 2 & 20,00 & 1 & 10,00 & 13 & 130,00 \\
\hline fissuras em tubulação & & - & & - & & - & & - & & - & & - \\
\hline fissuras verticais & & - & & - & & - & & - & & - & & - \\
\hline deformação das fôrmas & & - & & - & 1 & 10,00 & 2 & 20,00 & & - & & - \\
\hline reparo nos el. estrut. devido segregaçōes & & - & & - & & - & & - & & - & & - \\
\hline lixiviaçäo & 3 & 30,00 & 14 & 140,00 & 3 & 30,00 & 3 & 30,00 & & - & 13 & 130,00 \\
\hline eflorescências & 3 & 30,00 & 14 & 140,00 & 3 & 30,00 & 3 & 30,00 & & - & 13 & 130,00 \\
\hline falta de vibração & & - & & - & & - & & - & & - & & - \\
\hline desagregação do concreto & & - & & - & & - & & - & & - & & - \\
\hline mal posicionamento da armadura & & - & & - & & - & & - & & - & & - \\
\hline
\end{tabular}


Número de elementos estruturais (laje) por pavimento $=10$

$@$ = número de manifestaçőes patológicas por pavimento

$\%$ = porcentagem de manifestaçőes patológicas por pavimento

\begin{tabular}{|c|c|c|c|c|c|c|c|c|c|c|c|c|}
\hline PAVIMENTO & & avimento & & avimento & & ivimento & & avimento & & avimento & & avimento \\
\hline Tipo de manifestação patológica observada & @ & $\%$ & @ & $\%$ & @ & $\%$ & @ & $\%$ & @ & $\%$ & @ & $\%$ \\
\hline desaprumo & & - & & - & & - & & - & & - & & - \\
\hline torção da fôrma & & - & & - & & - & & - & & - & & - \\
\hline junta de concretagem & & - & & - & & - & & - & & - & & - \\
\hline falta de limpeza das fôrmas & & - & & - & & - & & - & & - & & - \\
\hline falta de estanqueidade das fôrmas & 10 & 100,00 & 8 & 80,00 & 7 & 70,00 & 5 & 50,00 & 4 & 40,00 & 8 & 80,00 \\
\hline falta de limpeza nos elementos estruturais & 1 & 10,00 & & - & & - & & - & & - & & - \\
\hline disgregação & 1 & 10,00 & & - & & - & & - & & - & & - \\
\hline bicheiras & & - & & - & & - & & - & & - & & - \\
\hline segregação do concreto & 1 & 10,00 & & - & & - & & - & & - & 4 & 40,00 \\
\hline falta de cobrimento de proteção das armaduras & & - & & - & & - & 1 & 10,00 & & - & & - \\
\hline efeito parede & & - & & - & & - & & - & & - & & - \\
\hline falta de alinhamento horizontal ou vertical & 2 & 20,00 & 2 & 20,00 & 1 & 10,00 & 1 & 10,00 & 1 & 10,00 & 4 & 40,00 \\
\hline carbonatação na superfície do concreto & 9 & 90,00 & 10 & 100,00 & 5 & 50,00 & 10 & 100,00 & 10 & 100,00 & 7 & 70,00 \\
\hline manchas de corrosão ou armadura corroída & & - & 1 & 10,00 & & - & 1 & 10,00 & & - & & - \\
\hline fissuras de retraçāo & & - & & - & & - & & - & & - & & - \\
\hline fissuras inclinadas & 9 & 90,00 & 7 & 70,00 & 3 & 30,00 & 6 & 60,00 & 10 & 100,00 & 5 & 50,00 \\
\hline fissuras em tubulação & & - & & - & & - & & - & & - & & - \\
\hline fissuras verticais & & - & & - & & - & & - & & - & & - \\
\hline deformação das fôrmas & 1 & 10,00 & & - & & - & & - & 1 & 10,00 & & - \\
\hline reparo nos el. estrut. devido segregaçōes & 9 & 90,00 & & - & & - & & - & & - & & - \\
\hline lixiviaçăo & 9 & 90,00 & 10 & 100,00 & 5 & 50,00 & 10 & 100,00 & 10 & 100,00 & 7 & 70,00 \\
\hline eflorescências & 9 & 90,00 & 10 & 100,00 & 5 & 50,00 & 10 & 100,00 & 10 & 100,00 & 7 & 70,00 \\
\hline falta de vibração & & - & & - & & - & & - & & - & & - \\
\hline desagregaçăo do concreto & & - & & - & & - & & - & & - & & - \\
\hline mal posicionamento da armadura & & - & & - & & - & & - & & - & & - \\
\hline
\end{tabular}


Número de elementos estruturais (laje) por pavimento $=10$

@ = número de manifestações patológicas por pavimento

$\%$ = porcentagem de manifestações patológicas por pavimento

\begin{tabular}{|c|c|c|c|c|c|c|c|c|c|c|c|c|}
\hline PAVIMENTO & $12^{\circ}$ & avimento & $13^{\circ}$ & avimento & & avimento & $15^{\circ}$ & pavimento & $16^{\circ}$ & avimento & $17^{\circ}$ & avimento \\
\hline Tipo de manifestação patológica observada & $@$ & $\%$ & @ & $\%$ & $@$ & $\%$ & $@$ & $\%$ & @ & $\%$ & $@$ & $\%$ \\
\hline desaprumo & & - & & - & & - & & - & & - & & - \\
\hline torção da fôrma & & - & & - & & - & & - & & - & & - \\
\hline junta de concretagem & 1 & 10,00 & & - & & - & & - & & - & 2 & 20,00 \\
\hline falta de limpeza das fôrmas & & - & & - & & - & & - & & - & 1 & 10,00 \\
\hline falta de estanqueidade das formas & 4 & 40,00 & 7 & 70,00 & 7 & 70,00 & 10 & 100,00 & 10 & 100,00 & 4 & 40,00 \\
\hline falta de limpeza nos elementos estruturais & & - & 1 & 10,00 & 3 & 30,00 & 4 & 40,00 & 10 & 100,00 & 3 & 30,00 \\
\hline disgregação & & - & & - & & - & & - & & - & 3 & 30,00 \\
\hline bicheiras & & - & & - & & - & & - & & - & & - \\
\hline segregaçāo do concreto & 2 & 20,00 & & - & 2 & 20,00 & 2 & 20,00 & & - & 2 & 20,00 \\
\hline falta de cobrimento de proteção das armaduras & & - & & - & 2 & 20,00 & 1 & 10,00 & & - & 1 & 10,00 \\
\hline efeito parede & & - & & - & & - & & - & & - & & - \\
\hline falta de alinhamento horizontal ou vertical & 3 & 30,00 & & - & 1 & 10,00 & 2 & 20,00 & & - & 2 & 20,00 \\
\hline carbonatação na superfície do concreto & 5 & 50,00 & 4 & 40,00 & 3 & 30,00 & 10 & 100,00 & 7 & 70,00 & 4 & 40,00 \\
\hline manchas de corrosão ou armadura corroída & 1 & 10,00 & & - & & - & & - & & - & 5 & 50,00 \\
\hline fissuras de retraçāo & & - & & - & & - & & - & & - & & - \\
\hline fissuras inclinadas & 5 & 50,00 & 4 & 40,00 & 3 & 30,00 & 10 & 100,00 & 7 & 70,00 & 4 & 40,00 \\
\hline fissuras em tubulação & & - & & - & & - & & - & & - & & - \\
\hline fissuras verticais & & - & & - & & $\cdot$ & & - & & - & & - \\
\hline deformação das fôrmas & & - & 1 & 10,00 & & - & 2 & 20,00 & 1 & 10,00 & & - \\
\hline reparo nos el. estrut. devido segregaçōes & & - & & - & & - & & - & & - & & - \\
\hline lixiviaçäo & 5 & 50,00 & 4 & 40,00 & 3 & 30,00 & 10 & 100,00 & 7 & 70,00 & 4 & 40,00 \\
\hline eflorescências & 4 & 40,00 & 4 & 40,00 & 3 & 30,00 & 9 & 90,00 & 5 & 50,00 & 4 & 40,00 \\
\hline falta de vibração & & - & & - & & - & & - & & - & & - \\
\hline desagregação do concreto & & - & & - & & - & & - & & - & & - \\
\hline mal posicionamento da armadura & & - & & - & & - & & - & & - & & - \\
\hline
\end{tabular}


Elemento estrutural - VIGA

Número de elementos estruturais (viga) por pavimento $=22$

@ = número de manifestações patológicas por pavimento

$\%=$ porcentagem de manifestações patológicas por pavimento

\begin{tabular}{|c|c|c|c|c|c|c|c|c|c|c|c|c|}
\hline \multirow{2}{*}{$\begin{array}{l}\text { PAVIMENTO } \\
\text { Tipo de manifestação patológica observada }\end{array}$} & \multicolumn{2}{|c|}{ Térreo } & \multicolumn{2}{|c|}{$1^{\circ}$ pavimento } & \multicolumn{2}{|c|}{$2^{\circ}$ pavimento } & \multicolumn{2}{|c|}{$3^{\circ}$ pavimento } & \multicolumn{2}{|c|}{$4^{\circ}$ pavimento } & \multicolumn{2}{|c|}{$5^{\circ}$ pavimento } \\
\hline & @ & $\%$ & @ & $\%$ & @ & $\%$ & @ & $\%$ & @ & $\%$ & @ & $\%$ \\
\hline desaprumo & & - & & - & & - & & - & & - & & - \\
\hline torção da fôrma & & - & & - & & - & & - & & - & & - \\
\hline junta de concretagem & & - & & - & & - & & - & & - & & - \\
\hline falta de limpeza das fôrmas & 1 & 4,55 & 4 & 18,18 & 3 & 13,64 & & - & 2 & 9,09 & & - \\
\hline falta de estanqueidade das fôrmas & & - & & - & & - & 2 & 9,09 & 1 & 4,55 & & - \\
\hline falta de limpeza e.e concretados & & - & & - & & - & 1 & 4,55 & & - & & - \\
\hline disgregação & 2 & 9,09 & 4 & 18,18 & 4 & 18,18 & 1 & 4,55 & 4 & 18,18 & & - \\
\hline bicheiras & & - & & - & . & - & 1 & 4,55 & & - & & - \\
\hline segregação do concreto & 2 & 9,09 & 4 & 18,18 & & - & 4 & 18,18 & 1 & 4,55 & & - \\
\hline falta de cobrimento de proteção das armaduras & 3 & 13,64 & 8 & 36,36 & 10 & 45,45 & 7 & 31,82 & 12 & 54,55 & 3 & 13,64 \\
\hline efeito parede & & - & & - & & - & & - & & - & & - \\
\hline falta de alinhamento horizontal ou vertical & & - & 1 & 4,55 & 1 & 4,55 & 1 & 4,55 & 2 & 9,09 & 2 & 9,09 \\
\hline carbonatação na superfície do concreto & & - & & - & & - & 1 & 4,55 & & - & & - \\
\hline manchas de corrosão ou armadura corroída & 5 & 22,73 & 8 & 36,36 & 8 & 36,36 & 7 & 31,82 & 11 & 50,00 & 2 & 9,09 \\
\hline fissuras de retração & & - & & - & & - & & - & & - & & - \\
\hline fissuras inclinadas & & - & & - & & - & & - & & - & & - \\
\hline fissuras em tubulação & & - & & - & & - & & - & & - & & - \\
\hline fissuras verticais & & - & & - & & - & & - & & - & & - \\
\hline deformação das fôrmas & 1 & 4,55 & 1 & 4,55 & 2 & 9,09 & 2 & 9,09 & 3 & 13,64 & 3 & 13,64 \\
\hline reparo nos el. estrut. devido segregaçōes & & - & & - & & - & & - & & - & & - \\
\hline lixiviaçāo & & - & & - & & - & 1 & 4,55 & & - & & - \\
\hline eflorescências & & - & & - & & - & 1 & 4,55 & & - & & - \\
\hline falta de vibração & & - & & - & & - & & - & & - & & - \\
\hline desagregação do concreto & & - & & - & & - & & - & & - & & - \\
\hline mal posicionamento da armadura & & - & 2 & 9,09 & & - & 1 & 4,55 & 1 & 4,55 & & - \\
\hline
\end{tabular}


Elemento estrutural - VIGA

Número de elementos estruturais (viga) por pavimento $=22$

@ = número de manifestações patológicas por pavimento

$\%=$ porcentagem de manifestações patológicas por pavimento

\begin{tabular}{|c|c|c|c|c|c|c|c|c|c|c|c|c|}
\hline \multirow{2}{*}{$\begin{array}{l}\text { PAVIMENTO } \\
\text { Tipo de manifestação patológica observada }\end{array}$} & \multicolumn{2}{|c|}{$6^{\circ}$ pavimento } & \multicolumn{2}{|c|}{$7^{\circ}$ pavimento } & \multicolumn{2}{|c|}{$8^{\circ}$ pavimento } & \multicolumn{2}{|c|}{$9^{\circ}$ pavimento } & \multicolumn{2}{|c|}{$10^{\circ}$ pavimento } & \multicolumn{2}{|c|}{$11^{\circ}$ pavimento } \\
\hline & @ & $\%$ & @ & $\%$ & @ & $\%$ & @ & $\%$ & @ & $\%$ & @ & $\%$ \\
\hline desaprumo & & - & & - & & - & & - & & - & & - \\
\hline torção da fôrma & & - & & - & 1 & 4,55 & & - & & - & & - \\
\hline junta de concretagem & & - & & - & & - & & - & & - & & - \\
\hline falta de limpeza das fôrmas & 3 & 13,64 & 2 & 9,09 & 3 & 13,64 & 1 & 4,55 & 3 & 13,64 & & - \\
\hline falta de estanqueidade das fôrmas & 1 & 4,55 & 2 & 9,09 & & - & 2 & 9,09 & & - & 2 & 9,09 \\
\hline falta de limpeza nos elementos estruturais & & - & & - & & - & 1 & 4,55 & & - & 2 & 9,09 \\
\hline disgregação & 1 & 4,55 & 1 & 4,55 & 1 & 4,55 & & - & 1 & 4,55 & & - \\
\hline bicheiras & & - & & - & 1 & 4,55 & & - & & - & 2 & 9,09 \\
\hline segregação do concreto & 1 & 4,55 & 1 & 4,55 & 3 & 13,64 & 1 & 4,55 & & - & 2 & 9,09 \\
\hline falta de cobrimento de proteção das armaduras & 10 & 45,45 & 4 & 18,18 & 7 & 31,82 & 9 & 40,91 & 4 & 18,18 & 10 & 45,45 \\
\hline efeito parede & & - & & - & & - & & - & & - & & - \\
\hline falta de alinhamento horizontal ou vertical & & - & 2 & 9,09 & 1 & 4,55 & 2 & 9,09 & 2 & 9,09 & 5 & 22,73 \\
\hline carbonatação na superficie do concreto & & - & & - & & - & & - & & - & & - \\
\hline manchas de corrosão ou armadura corroída & 11 & 50,00 & & - & 5 & 22,73 & 1 & 4,55 & 2 & 9,09 & 4 & 18,18 \\
\hline fissuras de retração & & - & & - & & - & & - & & - & & - \\
\hline fissuras inclinadas & & - & & - & & - & & - & & - & & - \\
\hline fissuras em tubulação & & - & & - & & - & & - & & - & & - \\
\hline fissuras verticais & & - & & - & & - & & - & & - & & - \\
\hline deformação das fôrmas & 2 & 9,09 & 2 & 9,09 & 3 & 13,64 & 2 & 9,09 & & - & 5 & 22,73 \\
\hline reparo nos el. estrut. devido segregaçōes & & - & & - & & - & & - & & - & & - \\
\hline lixiviaçäo & & - & & - & & - & & - & & - & & - \\
\hline eflorescências & & - & & - & & - & & - & & - & & - \\
\hline falta de vibração & & - & & - & & - & & - & & - & & - \\
\hline desagregação do concreto & & - & & - & & - & & - & & - & & - \\
\hline mal posicionamento da armadura & 1 & 4,55 & & - & & - & 1 & 4,55 & & - & & - \\
\hline
\end{tabular}


Elemento estrutural - VIGA

Número de elementos estruturais (viga) por pavimento $=22$

@ = número de manifestações patológicas por pavimento

$\%=$ porcentagem de manifestações patológicas por pavimento

\begin{tabular}{|c|c|c|c|c|c|c|c|c|c|c|c|c|}
\hline \multirow{2}{*}{$\begin{array}{l}\text { PAVIMENTO } \\
\text { Tipo de manifestação patológica observada }\end{array}$} & \multicolumn{2}{|c|}{$12^{\circ}$ pavimento } & \multicolumn{2}{|c|}{$13^{\circ}$ pavimento } & \multicolumn{2}{|c|}{$14^{\circ}$ pavimento } & \multicolumn{2}{|c|}{$15^{\circ}$ pavimento } & \multicolumn{2}{|c|}{$16^{\circ}$ pavimento } & \multicolumn{2}{|c|}{$17^{\circ}$ pavimento } \\
\hline & @ & $\%$ & @ & $\%$ & @ & $\%$ & @ & $\%$ & @ & $\%$ & @ & $\%$ \\
\hline desaprumo & & - & & - & & - & & - & & - & & - \\
\hline torção da fôrma & & - & & - & 1 & 4,55 & & - & & - & & - \\
\hline junta de concretagem & & - & & - & & - & & - & & - & 1 & 4,55 \\
\hline falta de limpeza das fôrmas & 2 & 9,09 & 3 & 13,64 & 2 & 9,09 & 1 & 4,55 & 1 & 4,55 & 1 & 4,55 \\
\hline falta de estanqueidade das fôrmas & 3 & 13,64 & 5 & 22,73 & 4 & 18,18 & 4 & 18,18 & 6 & 27,27 & 5 & 22,73 \\
\hline falta de limpeza nos elementos estruturais & & - & & - & & - & 2 & 9,09 & 12 & 54,55 & 6 & 27,27 \\
\hline disgregação & & - & & - & & - & 1 & 4,55 & & - & & - \\
\hline bicheiras & 1 & 4,55 & & - & 2 & 9,09 & 1 & 4,55 & & - & & - \\
\hline segregação do concreto & 3 & 13,64 & 4 & 18,18 & 7 & 31,82 & 6 & 27,27 & 10 & 45,45 & 10 & 45,45 \\
\hline falta de cobrimento de proteção das armaduras & 5 & 22,73 & 5 & 22,73 & 5 & 22,73 & 7 & 31,82 & 1 & 4,55 & 9 & 40,91 \\
\hline efeito parede & & - & & - & & - & & - & & - & & - \\
\hline falta de alinhamento horizontal ou vertical & 3 & 13,64 & & - & 1 & 4,55 & 3 & 13,64 & 3 & 13,64 & 2 & 9,09 \\
\hline carbonatação na superfície do concreto & 2 & 9,09 & 1 & 4,55 & & - & 2 & 9,09 & & - & & - \\
\hline manchas de corrosão ou armadura corroída & 4 & 18,18 & 1 & 4,55 & 1 & 4,55 & 3 & 13,64 & & - & 3 & 13,64 \\
\hline fissuras de retraçāo & & - & & - & & - & & - & & - & & - \\
\hline fissuras inclinadas & & - & & - & & - & & - & & - & & - \\
\hline fissuras em tubulação & & - & & - & & - & & - & & - & & - \\
\hline fissuras verticais & & - & & - & & - & & - & & - & & - \\
\hline deformação das fôrmas & 5 & 22,73 & 3 & 13,64 & 4 & 18,18 & 6 & 27,27 & 5 & 22,73 & 8 & 36,36 \\
\hline reparo nos el. estrut. devido segregaçōes & & - & & - & & - & & - & & - & & - \\
\hline lixiviaçäo & 2 & 9,09 & 1 & 4,55 & & - & 2 & 9,09 & & - & & - \\
\hline eflorescências & 1 & 4,55 & 1 & 4,55 & & - & 2 & 9,09 & & - & & - \\
\hline falta de vibração & & - & & - & & - & & - & & - & & - \\
\hline desagregação do concreto & & - & & - & & - & & - & & - & & - \\
\hline mal posicionamento da armadura & & - & 1 & 4,55 & & - & 1 & 4,55 & & - & & - \\
\hline
\end{tabular}




\section{Elemento estrutural - PILAR}

Número de elementos estruturais (pilar) por pavimento $=9$

$@$ = número de manifestações patológicas por pavimento

$\%=$ porcentagem de manifestações patológicas por pavimento

\begin{tabular}{|c|c|c|c|c|c|c|c|c|c|c|c|c|}
\hline PAVIMENTO & & érreo & & avimento & $2^{\circ} \mathrm{pa}$ & imento & & avimento & & avimento & $5^{\circ} \mathrm{p}$ & avimento \\
\hline Tipo de manifestação patológica observada & $@$ & $\%$ & @ & $\%$ & @ & $\%$ & $@$ & $\%$ & $@$ & $\%$ & @ & $\%$ \\
\hline desaprumo & & - & 1 & 11,11 & & - & & - & & - & & - \\
\hline torção da fôrma & & - & & - & & - & & - & & - & & - \\
\hline junta de concretagem & & - & & - & & - & & - & & - & & - \\
\hline falta de limpeza das formas & & - & & - & & - & & - & & - & & - \\
\hline falta de estanqueidade das fôrmas & & - & & - & & - & & - & & - & & - \\
\hline falta de limpeza nos elementos estruturais & & - & & - & 2 & 22,22 & & - & & - & 4 & 44,44 \\
\hline disgregação & & - & & - & & - & & - & & - & & - \\
\hline bicheiras & & - & & - & & - & & - & 1 & 11,11 & 1 & 11,11 \\
\hline segregação do concreto & & - & & - & & - & 8 & 88,89 & 8 & 88,89 & 1 & 11,11 \\
\hline falta de cobrimento de proteção das armaduras & & - & & - & & - & & - & & - & 1 & 11,11 \\
\hline efeito parede & & - & & - & & - & & - & & - & & - \\
\hline falta de alinhamento horizontal ou vertical & & - & 1 & 11,11 & & - & & - & 1 & 11,11 & 1 & 11,11 \\
\hline carbonatação na superficie do concreto & 8 & 88,89 & 9 & 100,00 & 9 & 100,00 & 9 & 100,00 & 9 & 100,00 & 9 & 100,00 \\
\hline manchas de corrosão ou armadura corroída & & - & 1 & 11,11 & & - & & - & & - & & - \\
\hline fissuras de retração & & - & & - & & - & & - & & - & & - \\
\hline fissuras inclinadas & & - & & - & & - & & - & & - & & - \\
\hline fissuras em tubulação & & - & & - & & - & & - & & - & & - \\
\hline fissuras verticais & & - & & - & & - & & - & & - & & - \\
\hline deformação das fôrmas & & - & & - & 1 & 11,11 & 1 & 11,11 & 2 & 22,22 & & - \\
\hline reparo nos el. estrut. devido segregaçōes & & - & & - & & - & 2 & 22,22 & & - & & - \\
\hline lixiviaçāo & & - & 1 & 11,11 & & - & & - & & - & & - \\
\hline eflorescências & & - & 1 & 11,11 & & - & & - & & - & & - \\
\hline falta de vibração & & - & & - & & - & & - & & - & & - \\
\hline desagregação do concreto & & - & & - & & - & & - & & - & & - \\
\hline mal posicionamento da armadura & & - & & - & & - & & - & & - & & - \\
\hline
\end{tabular}


Elemento estrutural - PILAR

Número de elementos estruturais (pilar) por pavimento $=9$

Q = número de manifestações patológicas por pavimento

$\%=$ porcentagem de manifestações patológicas por pavimento

\begin{tabular}{|c|c|c|c|c|c|c|c|c|c|c|c|c|}
\hline \multirow{2}{*}{$\begin{array}{l}\text { PAVIMENTO } \\
\text { Tipo de manifestação patológica observada }\end{array}$} & \multicolumn{2}{|c|}{$6^{\circ}$ pavimento } & \multicolumn{2}{|c|}{$7^{\circ}$ pavimento } & \multicolumn{2}{|c|}{$8^{\circ}$ pavimento } & \multicolumn{2}{|c|}{$9^{\circ}$ pavimento } & \multicolumn{2}{|c|}{$10^{\circ}$ pavimento } & \multicolumn{2}{|c|}{$11^{\circ}$ pavimento } \\
\hline & @ & $\%$ & @ & $\%$ & @ & $\%$ & @ & $\%$ & @ & $\%$ & @ & $\%$ \\
\hline desaprumo & & - & & - & & - & & - & & - & & - \\
\hline torção da fôrma & & - & & - & & - & & - & & - & & - \\
\hline junta de concretagem & & - & & - & & - & & - & & - & & - \\
\hline falta de limpeza das fôrmas & & - & & - & & - & & - & 1 & 11,11 & & - \\
\hline falta de estanqueidade das fôrmas & & - & & - & 1 & 11,11 & & - & & - & & - \\
\hline falta de limpeza nos elementos estruturais & 3 & 33,33 & 2 & 22,22 & 3 & 33,33 & 1 & 11,11 & 2 & 22,22 & 1 & 11,11 \\
\hline disgregação & & - & & - & & - & & - & & - & & - \\
\hline bicheiras & & - & & - & 1 & 11,11 & & - & & - & 1 & 11,11 \\
\hline segregação do concreto & 7 & 77,78 & 6 & 66,67 & 7 & 77,78 & 5 & 55,56 & 7 & 77,78 & 7 & 77,78 \\
\hline falta de cobrimento de proteção das armaduras & 1 & 11,11 & & - & & - & & - & & - & & - \\
\hline efeito parede & & - & & - & & - & & - & & - & & - \\
\hline falta de alinhamento horizontal ou vertical & 3 & 33,33 & 1 & 11,11 & 2 & 22,22 & & - & 2 & 22,22 & 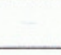 & - \\
\hline carbonatação na superficie do concreto & & - & & - & & - & & - & & - & & - \\
\hline manchas de corrosão ou armadura corroída & & - & & - & & - & & - & & - & & - \\
\hline fissuras de retração & & - & & - & & - & & - & & - & & - \\
\hline fissuras inclinadas & & - & & - & & - & & - & & - & & - \\
\hline fissuras em tubulação & & - & & - & & - & & - & & - & & - \\
\hline fissuras verticais & & - & & - & & - & & - & & - & & - \\
\hline deformação das fôrmas & 2 & 22,22 & 1 & 11,11 & 2 & 22,22 & 1 & 11,11 & 1 & 11,11 & 1 & 11,11 \\
\hline reparo nos el. estrut. devido segregaçōes & 1 & 11,11 & & - & & - & & - & & - & & - \\
\hline lixiviaçäo & & - & & - & & - & & - & & - & & - \\
\hline eflorescências & & - & & - & & - & & - & & - & & - \\
\hline falta de vibração & & - & & - & & - & & - & & - & & - \\
\hline desagregação do concreto & & - & & - & & - & & - & & - & & - \\
\hline mal posicionamento da armadura & & - & & - & & - & & - & & - & & - \\
\hline
\end{tabular}




\section{Elemento estrutural - PILAR}

Número de elementos estruturais (pilar) por pavimento $=9$

@ = número de manifestações patológicas por pavimento

$\%=$ porcentagem de manifestações patológicas por pavimento

\begin{tabular}{|c|c|c|c|c|c|c|c|c|c|c|c|c|}
\hline \multirow{2}{*}{$\begin{array}{l}\text { PAVIMENTO } \\
\text { Tipo de manifestação patológica observada }\end{array}$} & \multicolumn{2}{|c|}{$12^{\circ}$ pavimento } & \multicolumn{2}{|c|}{$13^{\circ}$ pavimento } & \multicolumn{2}{|c|}{$14^{\circ}$ pavimento } & \multicolumn{2}{|c|}{$15^{\circ}$ pavimento } & \multicolumn{2}{|c|}{$16^{\circ}$ pavimento } & \multicolumn{2}{|c|}{$17^{\circ}$ pavimento } \\
\hline & @ & $\%$ & @ & $\%$ & @ & $\%$ & @ & $\%$ & @ & $\%$ & @ & $\%$ \\
\hline desaprumo & & - & & - & & - & & - & & - & & - \\
\hline torção da fôrma & & - & 2 & 22,22 & & - & & - & 1 & 11,11 & & - \\
\hline junta de concretagem & & - & & - & & - & & - & & - & & - \\
\hline falta de limpeza das fôrmas & & - & & - & & - & & - & & - & & - \\
\hline falta de estanqueidade das fôrmas & & - & & - & 1 & 11,11 & 2 & 22,22 & 1 & 11,11 & & - \\
\hline falta de limpeza nos elementos estruturais & 2 & 22,22 & 1 & 11,11 & 7 & 77,78 & 5 & 55,56 & 8 & 88,89 & 4 & 44,44 \\
\hline disgregação & & - & & - & & - & & - & & - & & - \\
\hline bicheiras & & - & & - & & - & & - & 1 & 11,11 & & - \\
\hline segregação do concreto & 5 & 55,56 & 4 & 44,44 & 1 & 11,11 & 6 & 66,67 & 8 & 88,89 & 8 & 88,89 \\
\hline falta de cobrimento de proteção das armaduras & & - & & - & & - & & - & 1 & 11,11 & & - \\
\hline efeito parede & & - & & - & & - & & - & & - & & - \\
\hline falta de alinhamento horizontal ou vertical & 1 & 11,11 & & - & 1 & 11,11 & & - & & - & & - \\
\hline carbonatação na superficie do concreto & & - & & - & & - & & - & & - & & - \\
\hline manchas de corrosāo ou armadura corroída & & - & & - & & - & & - & 1 & 11,11 & & - \\
\hline fissuras de retração & & - & & - & & - & & - & & - & & - \\
\hline fissuras inclinadas & & - & & - & & - & & - & & - & & - \\
\hline fissuras em tubulação & & - & & - & & - & & - & & - & & - \\
\hline fissuras verticais & & - & & - & & - & & - & & - & & - \\
\hline deformação das fôrmas & & - & 1 & 11,11 & 2 & 22,22 & 1 & 11,11 & 2 & 22,22 & 1 & 11,11 \\
\hline reparo nos el. estrut. devido segregações & & - & 1 & 11,11 & & - & & - & & - & 2 & 22,22 \\
\hline lixiviaçāo & & - & & - & & - & & - & & - & & - \\
\hline eflorescências & & - & & - & & - & & - & & - & & - \\
\hline falta de vibração & & - & & - & & - & & - & & - & & - \\
\hline desagregação do concreto & & - & & - & & - & & - & & - & & - \\
\hline mal posicionamento da armadura & & - & & - & & - & & - & 1 & 11,11 & & - \\
\hline
\end{tabular}




\section{Elemento estrutural - PAREDE}

Número de elementos estruturais (parede) por pavimento $=5$

@ = número de manifestações patológicas por pavimento

$\%=$ porcentagem de manifestações patológicas por pavimento

\begin{tabular}{|c|c|c|c|c|c|c|c|c|c|c|c|c|}
\hline \multirow{2}{*}{$\begin{array}{l}\text { PAVIMENTO } \\
\text { Tipo de manifestação patológica observada }\end{array}$} & \multicolumn{2}{|c|}{ Térreo } & \multicolumn{2}{|c|}{$1^{\circ}$ pavimento } & \multicolumn{2}{|c|}{$2^{\circ}$ pavimento } & \multicolumn{2}{|c|}{$3^{\circ}$ pavimento } & \multicolumn{2}{|c|}{$4^{\circ}$ pavimento } & \multicolumn{2}{|c|}{$5^{\circ}$ pavimento } \\
\hline & @ & $\%$ & @ & $\%$ & @ & $\%$ & @ & $\%$ & @ & $\%$ & @ & $\%$ \\
\hline desaprumo & & - & & - & & - & & - & & - & & - \\
\hline torção da fôrma & & - & & - & & - & & - & & - & & - \\
\hline junta de concretagem & & - & & - & & - & & - & & - & & - \\
\hline falta de limpeza das fôrmas & & - & & - & & - & & - & & - & & - \\
\hline falta de estanqueidade das fôrmas & & - & & - & & - & & - & & - & & - \\
\hline falta de limpeza nos elementos estruturais & & - & & - & 1 & 20,00 & & - & 2 & 40,00 & 1 & 20,00 \\
\hline disgregação & & - & & - & & - & & - & & - & & - \\
\hline bicheiras & & - & & - & & - & & - & & - & & - \\
\hline segregação do concreto & & - & & - & 1 & 20,00 & 1 & 20,00 & 2 & 40,00 & & - \\
\hline falta de cobrimento de proteção das armaduras & & - & & - & & - & & - & & - & & - \\
\hline efeito parede & & - & & - & & - & & - & & - & & - \\
\hline falta de alinhamento horizontal ou vertical & & - & & - & 1 & 20,00 & & - & & - & & - \\
\hline carbonatação na superfície do concreto & & - & & - & & - & & - & & - & & - \\
\hline manchas de corrosão ou armadura corroída & & - & & - & & - & & - & & - & & - \\
\hline fissuras de retração & & - & & - & & - & & - & & - & & - \\
\hline fissuras inclinadas & & - & & - & & - & & - & & - & & - \\
\hline fissuras em tubulação & & - & & - & & - & & - & & - & & - \\
\hline fissuras verticais & & - & & - & & - & & - & & - & & - \\
\hline deformação das fôrmas & & - & & - & & - & & - & 3 & 60,00 & & - \\
\hline reparo nos el. estrut. devido segregaçōes & & - & & - & & - & 1 & 20,00 & & - & & - \\
\hline lixiviaçäo & & - & & - & & - & & - & & - & & - \\
\hline eflorescências & & - & & - & & - & & - & & - & & - \\
\hline falta de vibração & & - & & - & & - & & - & & - & & - \\
\hline desagregação do concreto & & - & & - & & - & & - & & - & & - \\
\hline mal posicionamento da armadura & & - & & - & & - & & - & & - & & - \\
\hline
\end{tabular}




\section{Elemento estrutural - PAREDE}

Número de elementos estruturais ( parede ) por pavimento $=5$

Q = número de manifestações patológicas por pavimento

$\%=$ porcentagem de manifestações patológicas por pavimento

\begin{tabular}{|c|c|c|c|c|c|c|c|c|c|c|c|c|}
\hline PAVIMENTO & $6^{\circ} \mathrm{r}$ & vimento & & vimento & & vimento & & ivimento & $10^{\circ}$ & vimento & $11^{\circ}$ & vimento \\
\hline Tipo de manifestação patológica observada & @ & $\%$ & @ & $\%$ & @ & $\%$ & @ & $\%$ & @ & $\%$ & @ & $\%$ \\
\hline desaprumo & & - & & - & & - & & - & & - & & - \\
\hline torção da fôrma & & - & & - & & - & & - & & - & & - \\
\hline junta de concretagem & & - & & - & & - & & - & & - & & - \\
\hline falta de limpeza das fôrmas & & - & & - & & - & & - & & - & & - \\
\hline falta de estanqueidade das fôrmas & & - & & - & & - & & - & & - & & - \\
\hline falta de limpeza nos elementos estruturais & 1 & 20,00 & & - & & - & & - & & - & 2 & 40,00 \\
\hline disgregação & & - & & - & & - & & - & & - & & - \\
\hline bicheiras & & - & & - & & - & & - & & - & & - \\
\hline segregação do concreto & 2 & 40,00 & 3 & 60,00 & 3 & 60,00 & 5 & 100,00 & 4 & 80,00 & 3 & 60,00 \\
\hline falta de cobrimento de proteção das armaduras & & - & & - & & - & & - & & - & & - \\
\hline efeito parede & & - & & - & & - & & - & & - & & - \\
\hline falta de alinhamento horizontal ou vertical & & - & & - & 1 & 20,00 & 2 & 40,00 & & - & & - \\
\hline carbonatação na superficie do concreto & & - & & - & & - & & - & & - & & - \\
\hline manchas de corrosão ou armadura corroída & & - & & - & & - & & - & & - & & - \\
\hline fissuras de retração & & - & & - & & - & & - & & - & & - \\
\hline fissuras inclinadas & & - & & - & & - & & - & & - & & - \\
\hline fissuras em tubulação & & - & & - & & - & & - & & - & & - \\
\hline fissuras verticais & & - & & - & & - & & - & & - & & - \\
\hline deformação das fôrmas & & - & & - & 1 & 20,00 & & - & & - & & - \\
\hline reparo nos el. estrut. devido segregações & & - & & - & & - & & - & & - & & - \\
\hline lixiviaçäo & & - & & - & & - & & - & & - & & - \\
\hline eflorescências & & - & & - & & - & & - & & - & & - \\
\hline falta de vibração & & - & & - & & - & & - & & - & & - \\
\hline desagregação do concreto & & - & & - & & - & & - & & - & & - \\
\hline mal posicionamento da armadura & & - & & - & & - & & - & & - & & - \\
\hline
\end{tabular}




\section{Elemento estrutural - PAREDE}

Número de elementos estruturais ( parede ) por pavimento $=5$

@ = número de manifestações patológicas por pavimento

$\%=$ porcentagem de manifestações patológicas por paṿimento

\begin{tabular}{|c|c|c|c|c|c|c|c|c|c|c|c|c|}
\hline \multirow{2}{*}{$\begin{array}{l}\text { PAVIMENTO } \\
\text { Tipo de manifestação patológica observada }\end{array}$} & \multicolumn{2}{|c|}{$12^{\circ}$ pavimento } & \multicolumn{2}{|c|}{$13^{\circ}$ pavimento } & \multicolumn{2}{|c|}{$14^{\circ}$ pavimento } & \multicolumn{2}{|c|}{$15^{\circ}$ pavimento } & \multicolumn{2}{|c|}{$16^{\circ}$ pavimento } & \multicolumn{2}{|c|}{$17^{\circ}$ pavimento } \\
\hline & @ & $\%$ & @ & $\%$ & @ & $\%$ & @ & $\%$ & @ & $\%$ & @ & $\%$ \\
\hline desaprumo & & - & & - & & - & & - & & - & & - \\
\hline torção da fôrma & & - & & - & & - & & - & & - & & - \\
\hline junta de concretagem & & - & & - & & - & & - & & - & & - \\
\hline falta de limpeza das fôrmas & & - & & - & & - & & - & & - & & - \\
\hline falta de estanqueidade das fôrmas & & - & & - & & - & & - & & - & & - \\
\hline falta de limpeza nos elementos estruturais & 1 & 20,00 & & - & & - & 3 & 60,00 & 2 & 40,00 & 3 & 60,00 \\
\hline disgregação & & - & & - & & - & & - & & - & & - \\
\hline bicheiras & & - & 2 & 40,00 & 2 & 40,00 & 3 & 60,00 & 1 & 20,00 & 3 & 60,00 \\
\hline segregação do concreto & 3 & 60,00 & 4 & 80,00 & 4 & 80,00 & 3 & 60,00 & 4 & 80,00 & 5 & 100,00 \\
\hline falta de cobrimento de proteção das armaduras & & - & 1 & 20,00 & & - & 1 & 20,00 & 1 & 20,00 & 1 & 20,00 \\
\hline efeito parede & & - & & - & & - & & - & & - & & - \\
\hline falta de alinhamento horizontal ou vertical & & - & & - & & - & & - & & - & & - \\
\hline carbonatação na superficie do concreto & & - & & - & & - & & - & & - & & - \\
\hline manchas de corrosão ou armadura corroída & & - & 1 & 20,00 & & - & 1 & 20,00 & & - & 1 & 20,00 \\
\hline fissuras de retração & & - & & - & & - & & - & & - & & - \\
\hline fissuras inclinadas & & - & & - & & - & & - & & - & & - \\
\hline fissuras em tubulação & & - & & - & & - & & - & & - & & - \\
\hline fissuras verticais & & - & & - & & - & & - & & - & & - \\
\hline deformação das fôrmas & & - & & - & 1 & 20,00 & & - & & - & 1 & 20,00 \\
\hline reparo nos el. estrut. devido segregações & 2 & 40,00 & & - & & - & & - & & - & & - \\
\hline lixiviaçāo & & - & & - & & - & & - & & - & & - \\
\hline eflorescências & & - & & - & & - & & - & & - & & - \\
\hline falta de vibração & & - & & - & & - & & - & & - & & - \\
\hline desagregação do concreto & & - & & - & & - & & - & & - & & - \\
\hline mal posicionamento da armadura & & - & & - & & - & & - & & - & & - \\
\hline
\end{tabular}


ANEXO $\mathbf{J}$ - Tabelas quantitativas das ocorrências de cada elemento estrutural do Edifício J 
Número de elementos estruturais (laje) por pavimento $=19$

@= número de manifestações patológicas por pavimento

$\%=$ porcentagem de manifestações patológicas por pavimento

\begin{tabular}{|c|c|c|c|c|c|c|c|c|c|c|}
\hline \multirow{2}{*}{$\begin{array}{l}\text { PAVIMENTO } \\
\text { Tipo de manifestação patológica observada }\end{array}$} & \multicolumn{2}{|c|}{$2^{\circ}$ pavimento } & \multicolumn{2}{|c|}{$3^{\circ}$ pavimento } & \multicolumn{2}{|c|}{$4^{\circ}$ pavimento } & \multicolumn{2}{|c|}{$5^{\circ}$ pavimento } & \multicolumn{2}{|c|}{$6^{\circ}$ pavimento } \\
\hline & @ & $\%$ & @ & $\%$ & @ & $\%$ & @ & $\%$ & @ & $\%$ \\
\hline desaprumo & & - & & - & & - & & - & & - \\
\hline torção da fôrma & & - & & - & & - & & - & & - \\
\hline junta de concretagem & 2 & 10,53 & & - & & - & & - & 2 & 10,53 \\
\hline falta de limpeza das formas & 7 & 36,84 & & - & & - & & - & 5 & 26,32 \\
\hline falta de estanqueidade das fôrmas & 3 & 15,79 & & - & & - & & - & & - \\
\hline falta de limpeza elementos estruturais & & - & & - & & - & & - & & - \\
\hline disgregação & 1 & 5,26 & & - & & - & & - & 1 & 5,26 \\
\hline bicheiras & & - & & - & & - & & - & & - \\
\hline segregação do concreto & 1 & 5,26 & & - & & - & & - & 3 & 15,79 \\
\hline falta de cobrimento de proteção das armaduras & 4 & 21,05 & & - & & - & & - & & - \\
\hline efeito parede & 1 & 5,26 & & - & & - & & - & 3 & 15,79 \\
\hline falta de alinhamento horizontal ou vertical & 5 & 26,32 & & - & & - & & - & 4 & 21,05 \\
\hline carbonatação na superfície do concreto & 2 & 10,53 & & - & & - & & - & 34 & 178,95 \\
\hline manchas de corrosão ou armadura corroída & 5 & 26,32 & & - & & - & & - & 9 & 47,37 \\
\hline fissuras de retração & & - & & - & & - & & - & & - \\
\hline fissuras inclinadas & 1 & 5,26 & & - & & - & & - & 20 & 105,26 \\
\hline fissuras em tubulação & & - & & - & & - & & - & & - \\
\hline fissuras verticais & & - & & - & & - & & - & & - \\
\hline deformação das fôrmas & 1 & 5,26 & & - & & - & & - & 1 & 5,26 \\
\hline reparo nos el. estrut. devido segregaçōes & & - & & - & & - & & - & & - \\
\hline lixiviação & 2 & 10,53 & & - & & - & & - & 34 & 178,95 \\
\hline eflorescências & 2 & 10,53 & & - & & - & & - & 30 & 157,89 \\
\hline falta de vibração & & - & & - & & - & & - & & - \\
\hline desagregação do concreto & & - & & - & & - & & - & & - \\
\hline
\end{tabular}




\section{Elemento estrutural - LAJE}

Número de elementos estruturais ( laje ) por pavimento $=19$

@ = número de manifestações patológicas por pavimento

$\%=$ porcentagem de manifestações patológicas por pavimento

\begin{tabular}{|c|c|c|c|c|c|c|c|c|c|c|}
\hline \multirow{2}{*}{$\begin{array}{l}\text { PAVIMENTO } \\
\text { Tipo de manifestação patológica observada }\end{array}$} & \multicolumn{2}{|c|}{$7^{\circ}$ pavimento } & \multicolumn{2}{|c|}{$8^{\circ}$ pavimento } & \multicolumn{2}{|c|}{$9^{\circ}$ pavimento } & \multicolumn{2}{|c|}{$10^{\circ}$ pavimento } & \multicolumn{2}{|c|}{$11^{\circ}$ pavimento } \\
\hline & @ & $\%$ & @ & $\%$ & @ & $\%$ & @ & $\%$ & @ & $\%$ \\
\hline desaprumo & & - & & - & & - & & - & & - \\
\hline torção da fôrma & & - & & - & & - & & - & & - \\
\hline junta de concretagem & 3 & 15,79 & 2 & 10,53 & 1 & 5,26 & 2 & 10,53 & 3 & 15,79 \\
\hline falta de limpeza das fôrmas & 9 & 47,37 & 6 & 31,58 & 10 & $52, \varpi 3$ & & - & 2 & 10,53 \\
\hline falta de estanqueidade das fôrmas & 3 & 15,79 & 5 & 26,32 & 3 & 15,79 & 1 & 5,26 & & - \\
\hline falta de limpeza nos elementos estruturais & & - & & - & & - & & - & & - \\
\hline disgregação & 1 & 5,26 & 2 & 10,53 & 2 & 10,53 & & - & 2 & 10,53 \\
\hline bicheiras & 1 & 5,26 & & - & & - & & - & & - \\
\hline segregação do concreto & 6 & 31,58 & 1 & 5,26 & 2 & 10,53 & & - & 1 & 5,26 \\
\hline falta de cobrimento de proteção das armaduras & 11 & 57,89 & 6 & 31,58 & 6 & 31,58 & 1 & 5,26 & 7 & 36,84 \\
\hline efeito parede & 3 & 15,79 & 2 & 10,53 & 3 & 15,79 & 1 & 5,26 & & - \\
\hline falta de alinhamento horizontal ou vertical & 5 & 26,32 & 4 & 21,05 & 4 & 21,05 & & - & & - \\
\hline carbonatação na superficie do concreto & 25 & 131,58 & & - & 3 & 15,79 & 9 & 47,37 & 9 & 47,37 \\
\hline manchas de corrosão ou armadura corroída & 12 & ஐ,16 & 4 & 21,05 & 7 & 36,84 & & - & 5 & 26,32 \\
\hline fissuras de retração & & - & & - & & - & & - & & - \\
\hline fissuras inclinadas & 22 & 115,79 & 11 & 57,89 & 2 & 10,53 & 2 & 10,53 & 3 & 15,79 \\
\hline fissuras em tubulação & & - & & - & & - & & - & & - \\
\hline fissuras verticais & & - & & - & & - & & - & & - \\
\hline deformação das fôrmas & & - & 1 & 5,26 & & - & & - & & - \\
\hline reparo nos el. estrut. devido segregaçōes & & - & & - & & - & & - & & - \\
\hline lixiviaçäo & 25 & 131,58 & 18 & 94,74 & 3 & 15,79 & 9 & 47,37 & 9 & 47,37 \\
\hline eflorescências & 25 & 131,58 & 17 & 89,47 & 4 & 21,05 & 7 & 36,84 & 10 & $52, \varpi 3$ \\
\hline falta de vibração & 3 & 15,79 & 1 & 5,26 & & - & & - & 1 & 5,26 \\
\hline desagregaçâo do concreto & & - & & - & & - & & - & & - \\
\hline
\end{tabular}


Elemento estrutural - VIGA

Número de elementos estruturais (viga) por pavimento $=29$

Q = número de manifestações patológicas por pavimento

$\%=$ porcentagem de manifestações patológicas por pavimento

\begin{tabular}{|c|c|c|c|c|c|c|c|c|c|c|}
\hline PAVIMENTO & & vimento & & nento & & nento & & nento & & imento \\
\hline Tipo de manifestação patológica observada & @ & $\%$ & @ & $\%$ & (C) & $\%$ & @ & $\%$ & @ & $\%$ \\
\hline desaprumo & & - & & - & & - & & - & & - \\
\hline torção da forma & 1 & 3,45 & & - & & - & & - & 5 & 17,24 \\
\hline junta de concretagem & 2 & 6,90 & & - & & - & & - & & - \\
\hline falta de limpeza das fôrmas & 10 & 34,48 & & - & & - & & - & & - \\
\hline falta de estanqueidade das fôrmas & & - & & - & & - & & - & & - \\
\hline falta de limpeza elementos estruturais & & - & & - & & - & & - & & - \\
\hline disgregação & 1 & 3,45 & & - & & - & & - & & - \\
\hline bicheiras & & - & & - & & - & & - & 1 & 3,45 \\
\hline segregação do concreto & 29 & 100,00 & & - & & - & & - & 2 & 6,90 \\
\hline falta de cobrimento de proteção das armaduras & 19 & 65,52 & & - & & - & & - & 4 & 13,79 \\
\hline efeito parede & & - & & - & & - & & - & & - \\
\hline falta de alinhamento horizontal ou vertical & 6 & 20,69 & & - & & - & & - & 1 & 3,45 \\
\hline carbonataçāo na superficie do concreto & & - & & - & & - & & - & & - \\
\hline manchas de corrosão ou armadura corroída & 4 & 13,79 & & - & & - & & - & 2 & 6,90 \\
\hline fissuras de retração & 1 & 3,45 & & - & & - & & - & & - \\
\hline fissuras inclinadas & & - & & - & & - & & - & & - \\
\hline fissuras em tubulação & 11 & 37,93 & & - & & - & & - & & - \\
\hline fissuras verticais & 5 & 17,24 & & - & & - & & - & 5 & 17,24 \\
\hline deformação das fôrmas & 3 & 10,34 & & - & & - & & - & 4 & 13,79 \\
\hline reparo nos el. estrut. devido segregaçōes & 5 & 17,24 & & - & & - & & - & & - \\
\hline lixiviaçăo & & - & & - & & - & & - & 1 & 3,45 \\
\hline eflorescências & & - & & - & & - & & - & & - \\
\hline falta de vibraçäo & & - & & - & & - & & - & & - \\
\hline desagregação do concreto & 1 & 3,45 & & - & & - & & - & & - \\
\hline
\end{tabular}

$3^{\circ}, 4^{\circ}$ e $5^{\circ}$ pavimentos rebocados 
Elemento estrutural - VIGA

Número de elementos estruturais (viga) por pavimento $=29$

@ = número de manifestaçöes patológicas por pavimento

$\%=$ porcentagem de manifestações patológicas por pavimento

\begin{tabular}{|c|c|c|c|c|c|c|c|c|c|c|}
\hline \multirow{2}{*}{$\begin{array}{l}\text { PAVIMENTO } \\
\text { Tipo de manifestação patológica observada }\end{array}$} & \multicolumn{2}{|c|}{$7^{\circ}$ pavimento } & \multicolumn{2}{|c|}{$8^{\circ}$ pavimento } & \multicolumn{2}{|c|}{$9^{\circ}$ pavimento } & \multicolumn{2}{|c|}{$10^{\circ}$ pavimento } & \multicolumn{2}{|c|}{$11^{\circ}$ pavimento } \\
\hline & @ & $\%$ & @ & $\%$ & $@$ & $\%$ & @ & $\%$ & $@$ & $\%$ \\
\hline desaprumo & & - & & - & & - & & - & & - \\
\hline torção da fôrma & 12 & 41,38 & 3 & 10,34 & 6 & 20,69 & 5 & 17,24 & 2 & 6,90 \\
\hline junta de concretagem & 1 & 3,45 & 3 & 10,34 & 3 & 10,34 & 1 & 3,45 & 7 & 24,14 \\
\hline falta de limpeza das fôrmas & & - & 2 & 6,90 & & - & & - & & - \\
\hline falta de estanqueidade das fôrmas & & - & 5 & 17,24 & 3 & 10,34 & 1 & 3,45 & & - \\
\hline falta de limpeza nos elementos estruturais & & - & & - & & - & & - & & - \\
\hline disgregação & & - & & - & 1 & 3,45 & & - & & - \\
\hline bicheiras & 1 & 3,45 & 2 & 6,90 & 1 & 3,45 & 1 & 3,45 & 4 & 13,79 \\
\hline segregação do concreto & 6 & 20,69 & 32 & 110,34 & 31 & 106,90 & 32 & 110,34 & 25 & 86,21 \\
\hline falta de cobrimento de proteção das armaduras & 5 & 17,24 & 18 & 62,07 & 4 & 13,79 & 1 & 3,45 & 3 & 10,34 \\
\hline efeito parede & & - & & - & & - & & - & & - \\
\hline falta de alinhamento horizontal ou vertical & 3 & 10,34 & 8 & 27,59 & 1 & 3,45 & 3 & 10,34 & 4 & 13,79 \\
\hline carbonatação na superficie do concreto & 6 & 20,69 & 5 & 17,24 & 2 & 6,90 & 2 & 6,90 & 1 & 3,45 \\
\hline manchas de corrosão ou armadura corroída & 1 & 3,45 & 8 & 27,59 & 3 & 10,34 & & - & 3 & 10,34 \\
\hline fissuras de retração & & - & & - & & - & & - & & - \\
\hline fissuras inclinadas & 2 & 6,90 & & - & & - & & - & & - \\
\hline fissuras em tubulação & 1 & 3,45 & 3 & 10,34 & & - & & - & & - \\
\hline fissuras verticais & 6 & 20,69 & 7 & 24,14 & & - & & - & & - \\
\hline deformação das fôrmas & 5 & 17,24 & 1 & 3,45 & 3 & 10,34 & 5 & 17,24 & 6 & 20,69 \\
\hline reparo nos el. estrut. devido segregaçōes & 2 & 6,90 & 1 & 3,45 & 5 & 17,24 & & - & 1 & 3,45 \\
\hline lixiviaçäo & 6 & 20,69 & 5 & 17,24 & 2 & 6,90 & 2 & 6,90 & 1 & 3,45 \\
\hline eflorescências & 6 & 20,69 & 5 & 17,24 & 2 & 6,90 & 1 & 3,45 & 1 & 3,45 \\
\hline falta de vibração & & - & & - & & - & & - & & - \\
\hline desagregação do concreto & & - & & - & & - & & - & & - \\
\hline
\end{tabular}

A partir do $8^{\circ}$ pavimento todas as faces das vigas puderam ser observadas 


\section{Elemento estrutural - PILAR}

Número de elementos estruturais (pilar) por pavimento $=20$

@ = número de manifestações patológicas por pavimento

$\%=$ porcentagem de manifestações patológicas por pavimento

\begin{tabular}{|c|c|c|c|c|c|c|c|c|c|c|}
\hline PAVIMENTO & & vimento & $3^{\circ} \mathrm{F}$ & iento & & ento & $5^{\circ} \mathrm{F}$ & lento & $6^{\circ} \mathrm{F}$ & vimento \\
\hline Tipo de manifestação patológica observada & @ & $\%$ & @ & $\%$ & @ & $\%$ & @ & $\%$ & @ & $\%$ \\
\hline desaprumo & & - & & - & & - & & - & & - \\
\hline torção da fôrma & 1 & 5,00 & & - & & - & & - & 2 & 10,00 \\
\hline junta de concretagem & 6 & 30,00 & & - & & - & & - & & - \\
\hline falta de limpeza das fôrmas & & - & & - & & - & & - & & - \\
\hline falta de estanqueidade das formas & & - & & - & & - & & - & & - \\
\hline falta de limpeza elementos estruturais & & - & & - & & - & & - & & - \\
\hline disgregação & & - & & - & & - & & - & & - \\
\hline bicheiras & & - & & - & & - & & - & & - \\
\hline segregação do concreto & 16 & 80,00 & & - & & - & & - & 22 & 110,00 \\
\hline falta de cobrimento de proteção das armaduras & & - & & - & & - & & - & 1 & 5,00 \\
\hline efeito parede & & - & & - & & - & & - & & - \\
\hline falta de alinhamento horizontal ou vertical & 1 & 5,00 & & - & & - & & - & 2 & 10,00 \\
\hline carbonatação na superfície do concreto & 20 & 100,00 & & - & & - & & - & 20 & 100,00 \\
\hline manchas de corrosão ou armadura corroída & & - & & - & & - & & - & 1 & 5,00 \\
\hline fissuras de retração & & - & & - & & - & & - & & - \\
\hline fissuras inclinadas & & - & & - & & - & & - & & - \\
\hline fissuras em tubulação & & - & & - & & - & & - & & - \\
\hline fissuras verticais & & - & & - & & - & & - & & - \\
\hline deformação das fôrmas & 6 & 30,00 & & - & & - & & - & 6 & 30,00 \\
\hline reparo nos el. estrut. devido segregaçōes & 1 & 5,00 & & - & & - & & - & 1 & 5,00 \\
\hline lixiviaçăo & & - & & - & & - & & - & 1 & 5,00 \\
\hline eflorescências & & - & & - & & - & & - & 1 & 5,00 \\
\hline falta de vibração & & - & & - & & - & & - & & - \\
\hline desagregação do concreto & & - & & - & & - & & - & & - \\
\hline
\end{tabular}

$3^{\circ}, 4^{\circ}$ e $5^{\circ}$ pavimentos rebocados 


\section{Elemento estrutural - PILAR}

Número de elementos estruturais (pilar) por pavimento $=20$

@ = número de manifestações patológicas por pavimento

$\%$ = porcentagem de manifestações patológicas por pavimento

\begin{tabular}{|c|c|c|c|c|c|c|c|c|c|c|}
\hline \multirow{2}{*}{$\begin{array}{l}\text { PAVIMENTO } \\
\text { Tipo de manifestação patológica observada }\end{array}$} & \multicolumn{2}{|c|}{$7^{\circ}$ pavimento } & \multicolumn{2}{|c|}{$8^{\circ}$ pavimento } & \multicolumn{2}{|c|}{$9^{\circ}$ pavimento } & \multicolumn{2}{|c|}{$10^{\circ}$ pavimento } & \multicolumn{2}{|c|}{$11^{\circ}$ pavimento } \\
\hline & @ & $\%$ & $@$ & $\%$ & @ & $\%$ & @ & $\%$ & $@$ & $\%$ \\
\hline desaprumo & & - & & - & & - & & - & & - \\
\hline torçāo da fôrma & & - & 3 & 15,00 & & - & 4 & 20,00 & 3 & 15,00 \\
\hline junta de concretagem & 1 & 5,00 & 5 & 25,00 & & - & & - & 1 & 5,00 \\
\hline falta de limpeza das fôrmas & & - & & - & & - & & - & & - \\
\hline falta de estanqueidade das fôrmas & & - & & - & & - & & - & & - \\
\hline falta de limpeza nos elementos estruturais & & - & 1 & 5,00 & & - & 3 & 15,00 & & - \\
\hline disgregaçāo & & - & & - & & - & & - & & - \\
\hline bicheiras & 1 & 5,00 & & - & & - & 1 & 5,00 & 1 & 5,00 \\
\hline segregação do concreto & 16 & 80,00 & 19 & 95,00 & 19 & 95,00 & 19 & 95,00 & 16 & 80,00 \\
\hline falta de cobrimento de proteção das armaduras & & - & & - & 1 & 5,00 & 1 & 5,00 & 2 & 10,00 \\
\hline efeito parede & & - & 1 & 5,00 & & - & & - & & - \\
\hline falta de alinhamento horizontal ou vertical & 1 & 5,00 & & - & 2 & 10,00 & & - & & - \\
\hline carbonatação na superfície do concreto & & - & & - & & - & & - & & - \\
\hline manchas de corrosão ou armadura corroída & & - & & - & 1 & 5,00 & 1 & 5,00 & 3 & 15,00 \\
\hline fissuras de retração & & - & & - & & - & & - & & - \\
\hline fissuras inclinadas & & - & & - & & - & & - & & - \\
\hline fissuras em tubulação & & - & & - & & - & & - & & - \\
\hline fissuras verticais & & - & & - & & - & & - & & - \\
\hline deformação das fôrmas & 3 & 15,00 & 3 & 15,00 & 2 & 10,00 & 1 & 5,00 & 4 & 20,00 \\
\hline reparo nos el. estrut. devido segregações & & - & & - & 3 & 15,00 & 5 & 25,00 & 2 & 10,00 \\
\hline lixiviaçăo & & - & 1 & 5,00 & & - & & - & & - \\
\hline eflorescências & & - & 1 & 5,00 & & - & & - & 1 & 5,00 \\
\hline falta de vibraçāo & & - & & - & & - & & - & & - \\
\hline desagregação do concreto & & - & & - & & - & & - & & - \\
\hline
\end{tabular}

desagregação do concreto 
Elemento estrutural - PAREDE

Número de elementos estruturais (parede) por pavimento $=5$

@ = número de manifestaçöes patológicas por pavimento

$\%$ = porcentagem de manifestaçöes patológicas por pavimento

\begin{tabular}{|c|c|c|c|c|c|c|c|c|c|c|}
\hline \multirow{2}{*}{$\begin{array}{l}\text { PAVIMENTO } \\
\text { Tipo de manifestação patológica observada }\end{array}$} & \multicolumn{2}{|c|}{$2^{\circ}$ pavimento } & \multicolumn{2}{|c|}{$3^{\circ}$ pavimento } & \multicolumn{2}{|c|}{$4^{\circ}$ pavimento } & \multicolumn{2}{|c|}{$5^{\circ}$ pavimento } & \multicolumn{2}{|c|}{$6^{\circ}$ pavimento } \\
\hline & $@$ & $\%$ & @ & $\%$ & @ & $\%$ & @ & $\%$ & @ & $\%$ \\
\hline desaprumo & & - & & - & & - & & - & & - \\
\hline torção da fôrma & & - & & - & & - & & - & & - \\
\hline junta de concretagem & 4 & 80,00 & & - & & - & & - & 1 & 20,00 \\
\hline falta de limpeza das fôrmas & & - & & - & & - & & - & & - \\
\hline falta de estanqueidade das fôrmas & & - & & - & 1 & 20,00 & 1 & 20,00 & 1 & 20,00 \\
\hline falta de limpeza elementos estruturais & & - & & - & & - & & - & & - \\
\hline disgregação & & - & & - & & - & & - & & - \\
\hline bicheiras & & - & & - & & - & & - & & - \\
\hline segregação do concreto & 4 & 80,00 & 4 & 80,00 & 1 & 20,00 & 7 & 140,00 & 4 & 80,00 \\
\hline falta de cobrimento de proteção das armaduras & & - & & - & & - & & - & & - \\
\hline efeito parede & & - & & - & & - & & - & & - \\
\hline falta de alinhamento horizontal ou vertical & 1 & 20,00 & 1 & 20,00 & & - & 1 & 20,00 & 1 & 20,00 \\
\hline carbonatação na superficie do concreto & & - & & - & & - & & - & & - \\
\hline manchas de corrosão ou armadura corroída & & - & & - & & - & & - & 1 & 20,00 \\
\hline fissuras de retração & & - & & - & & - & & - & & - \\
\hline fissuras inclinadas & & - & & - & & - & & - & & - \\
\hline fissuras em tubulação & & - & & - & & - & & - & & - \\
\hline fissuras verticais & & - & & - & & - & & - & & - \\
\hline deformação das fôrmas & 5 & 100,00 & 4 & 80,00 & 1 & 20,00 & 1 & 20,00 & 3 & 60,00 \\
\hline reparo nos el. estrut. devido segregaçōes & 3 & 60,00 & 3 & 60,00 & 9 & 180,00 & 9 & 180,00 & 5 & 100,00 \\
\hline lixiviaçăo & & - & & - & & - & & - & & - \\
\hline eflorescências & & - & & - & & - & & - & & - \\
\hline falta de vibração & & - & & - & & - & & - & & - \\
\hline desagregação do concreto & & - & & - & & - & & - & & - \\
\hline
\end{tabular}


Elemento estrutural - PAREDE

Número de elementos estruturais ( parede ) por pavimento $=5$

@ = número de manifestações patológicas por pavimento

$\%=$ porcentagem de manifestações patológicas por pavimento

\begin{tabular}{|c|c|c|c|c|c|c|c|c|c|c|}
\hline \multirow{2}{*}{$\begin{array}{l}\text { PAVIMENTO } \\
\text { Tipo de manifestação patológica observada }\end{array}$} & \multicolumn{2}{|c|}{$7^{\circ}$ pavimento } & \multicolumn{2}{|c|}{$8^{\circ}$ pavimento } & \multicolumn{2}{|c|}{$9^{\circ}$ pavimento } & \multicolumn{2}{|c|}{$10^{\circ}$ pavimento } & \multicolumn{2}{|c|}{$11^{\circ}$ pavimento } \\
\hline & @ & $\%$ & $@$ & $\%$ & @ & $\%$ & @ & $\%$ & @ & $\%$ \\
\hline desaprumo & & - & & - & & - & & - & & - \\
\hline torção da fôrma & & - & & - & & - & 1 & 20,00 & & - \\
\hline junta de concretagem & & - & 1 & 20,00 & & - & 2 & 40,00 & & - \\
\hline falta de limpeza das fôrmas & & - & & - & & - & & - & & - \\
\hline falta de estanqueidade & 2 & 40,00 & 2 & 40,00 & 3 & 60,00 & 1 & 20,00 & 2 & 40,00 \\
\hline falta de limpeza nos elementos estruturais & 1 & 20,00 & & - & 1 & 20,00 & 1 & 20,00 & 1 & 20,00 \\
\hline disgregaçăo & & - & & - & & - & & - & & - \\
\hline bixeiras & & - & 1 & 20,00 & & - & & - & & - \\
\hline segregação & 3 & 60,00 & 11 & 220,00 & 9 & 180,00 & 12 & 240,00 & 3 & $60, \infty 0$ \\
\hline falta de cobrimento & & - & & - & & - & 3 & 60,00 & & - \\
\hline efeito parede & & - & & - & & - & & - & & - \\
\hline falta alinhamento $\mathrm{h} / \mathrm{v}$ & & - & 1 & 20,00 & 1 & 20,00 & & - & & - \\
\hline carbonatação & & - & & - & & - & & - & & - \\
\hline armadura corroída & & - & & - & & - & 4 & 80,00 & 2 & 40,00 \\
\hline fissuras de retração & & - & & - & & - & & - & & - \\
\hline fissuras inclinadas & & - & & - & & - & & - & & - \\
\hline fissuras em tubulação & & - & & - & & - & & - & & - \\
\hline fissuras verticais & & - & & - & & - & & - & & - \\
\hline deformação das fôrmas & 2 & 40,00 & 5 & 100,00 & 3 & $60, \infty 0$ & 1 & 20,00 & 2 & 40,00 \\
\hline reparos nos e.e devido segregaçōes & 11 & 220,00 & 20 & 400,00 & 14 & 280,00 & 19 & 380,00 & 5 & 100,00 \\
\hline lixiviaçäo & & - & 2 & 40,00 & & - & & - & 2 & 40,00 \\
\hline eflorescências & & - & 1 & 20,00 & & - & & - & & - \\
\hline falta de vibração & & - & & - & & - & & - & & - \\
\hline desagregação & & - & & - & & - & & - & & - \\
\hline
\end{tabular}


ANEXO L - Tabelas quantitativas das ocorrências de cada elemento estrutural do Edifício L 


\section{Elemento estrutural - LAJE}

Número de elementos estruturais (laje) por pavimento $=15$

@ = número de manifestaçőes patológicas por pavimento

$\%$ = porcentagem de manifestações patológicas por pavimento

\begin{tabular}{|c|c|c|c|c|c|c|c|c|}
\hline \multirow{2}{*}{$\begin{array}{l}\text { PAVIMENTO } \\
\text { Tipo de manifestação patológica observada }\end{array}$} & \multicolumn{2}{|c|}{ Térreo } & \multicolumn{2}{|c|}{$1^{0}$ pavimento } & \multicolumn{2}{|c|}{$2^{\circ}$ pavimento } & \multicolumn{2}{|c|}{$3^{\circ}$ pavimento } \\
\hline & @ & $\%$ & @ & $\%$ & $@$ & $\%$ & $@$ & $\%$ \\
\hline desaprumo & & - & & - & & - & & - \\
\hline torção da fôrma & & - & & - & & - & & - \\
\hline junta de concretagem & & - & & - & & - & & - \\
\hline falta de limpeza das fôrmas & & - & & - & & - & & - \\
\hline falta de estanqueidade & 5 & 33,33 & 7 & 46,67 & 6 & 40,00 & 8 & 53,33 \\
\hline falta de limpeza nos elementos estruturais & & - & & - & & - & & - \\
\hline disgregação & & - & & - & & - & & - \\
\hline bicheiras & & - & & - & & - & & - \\
\hline segregação do concreto & & - & & - & & - & & - \\
\hline falta de cobrimento de proteção das armaduras & & - & & - & & - & & - \\
\hline efeito parede & & - & & - & & - & & - \\
\hline falta de alinhamento horizontal ou vertical & & - & & - & & - & & - \\
\hline carbonatação na superfície do concreto & & - & & - & & - & & - \\
\hline manchas de corrosão ou armadura corroída & & - & & - & & - & & - \\
\hline fissuras de retração & & - & & - & & - & & - \\
\hline fissuras inclinadas & & - & & - & & - & & - \\
\hline fissuras em tubulação & & - & & - & & - & & - \\
\hline fissuras verticais & & - & & - & & - & & - \\
\hline deformação das fôrmas & & - & & - & & - & & - \\
\hline reparo nos el. estrut. devido segregações & & - & & - & & - & & - \\
\hline lixiviaçăo & & - & & - & & - & & - \\
\hline eflorescências & & - & & - & & - & & - \\
\hline falta de vibraçāo & & - & & - & & - & & - \\
\hline desagregação do concreto & & - & & - & & - & & - \\
\hline
\end{tabular}


Elemento estrutural - VIGA

Número de elementos estruturais (viga) por pavimento $=36$

$@=$ número de manifestaçőes patológicas por pavimento

$\%$ = porcentagem de manifestações patológicas por pavimento

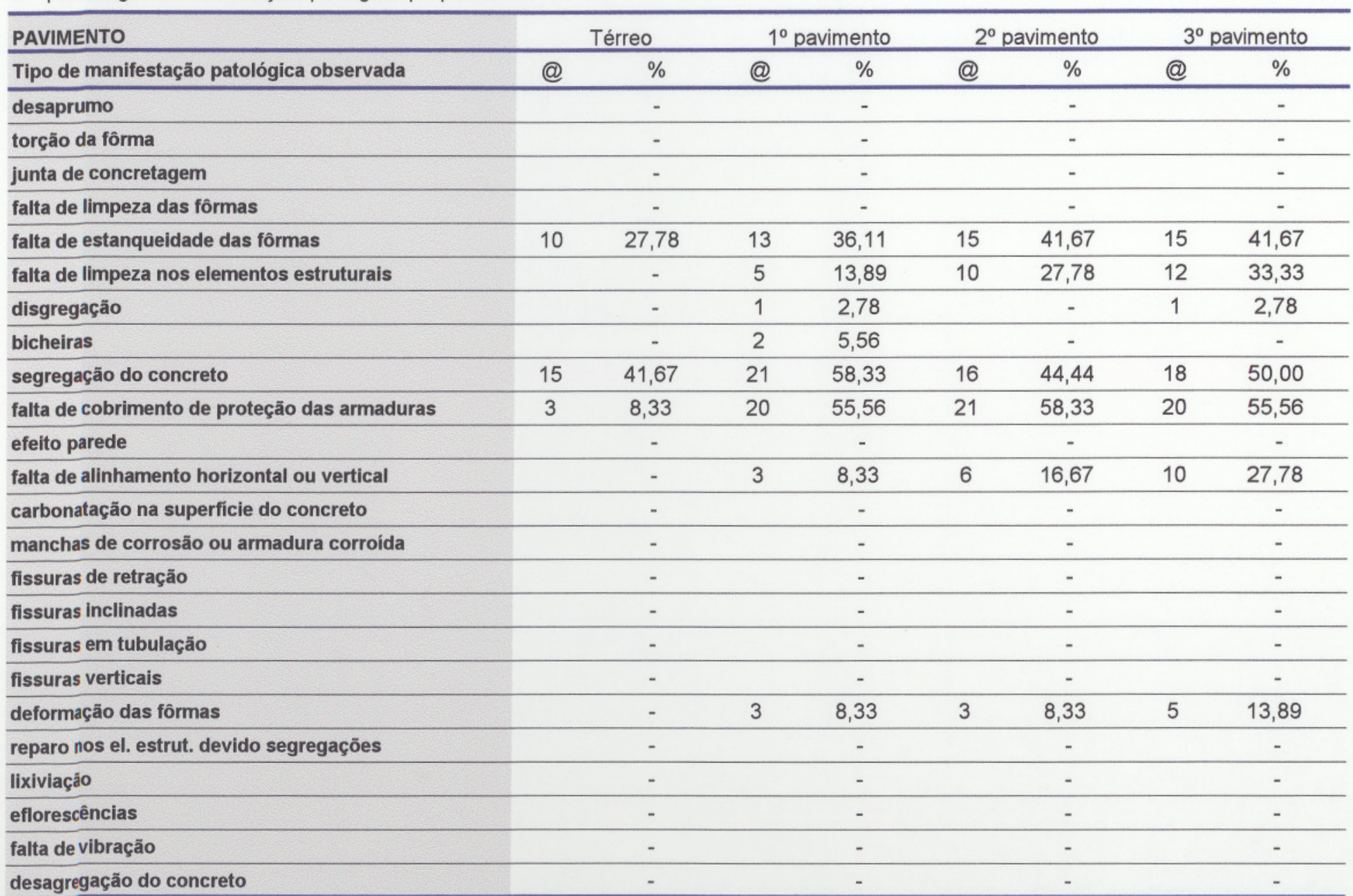




\section{Elemento estrutural - PILAR}

Número de elementos estruturais (pilar) por pavimento $=27$

@ = número de manifestaçőes patológicas por pavimento

$\%=$ porcentagem de manifestacões patológicas por pavimento

PAVIMENTO $1^{\circ}$ pavimento $\quad 2^{\circ}$ pavimento

Tipo de manifestação patológica observada @ Térreo

desaprumo

torção da fôrma

junta de concretagem

falta de limpeza das fôrmas

falta de estanqueidade das formas

falta de limpeza elementos estruturais

disgregação

bicheiras

segregação do concreto

$\%$

\% @ \%

$\%$

$3^{\circ}$ pavimento

falta de cobrimento de proteção das armaduras

efeito parede

falta de alinhamento horizontal ou vertical

carbonatação na superficie do concreto

manchas de corrosão ou armadura corroída

fissuras de retração

fissuras inclinadas

fissuras em tubulação

fissuras verticais

deformação das fôrmas

reparo nos el. estrut. devido segregaçōes

lixiviaçåo

eflorescências

falta de vibração

desagregação do concreto 


\section{GLOSSÁRIO}

ADENSAMENTO: É quando durante a concretagem e imediatamente após o lançamento, o concreto deve ser vibrado ou socado contínua e energicamente com equipamento adequado à trabalhabilidade do concreto.

ANAMNESE: Quadro de informações do início e evolução do problema patológico até o primeiro contato do técnico revendo a história da obra, conhecimentos técnicos existentes em determinada data, etc.

ANCORAGEM (C.A): Compressão ou o efeito de prender melhor os terminais dos aços normalizados que compõem a armadura de tração ou dar-lhes maior firmeza contra o deslizamento, que para isso são desviados para a zona de compressão, mediante dobramento a $90^{\circ}$ ou $45^{\circ}$ e encurvamento das pontas em gancho.

CAPITÉL: Enrijecimento para prevenir possíveis efeitos de punção e cisalhamento na ligação entre lajes e pilares.

CARGA ACIDENTAL: Carga que se considera não atuando permanentemente.

CARGA DE RUÍNA: Carga sob a qual se dá a ruína da estrutura, isto é, sob a qual a estrutura deixa de ser útil aos fins que foi feita, ou por se ter rompido, ou por se ter tornado hipostática, ou por ter flambado, ou por ter sofrido deformações exageradas, ou por ter fissurado além do limite prescrito. 
CARGA DE RUPTURA: Carga sob a qual rompe a estrutura (ou uma de suas partes)

CARGA LIMITE DE DEFORMAÇÃO: Carga sob a qual a estrutura (ou uma de suas partes) atinge o limite de deformação que lhe é prescrito.

CARGA MÓVEL: Carga acidental que se desloca relativamente à estrutura em que atua, considerando-se a posição relativa dos esforços que a compõem.

CARGA PERMANENTE: Carga que se considera aplicada permanentemente ou de longa duração.

COBRIMENTO: Espessura da camada exterior compreendida entre a ferragem mais externa e a face acabada da seção de uma peça de concreto armado que, por obrigatoriedade normativa, deve ser observada na sua execução para proteger a armadura contra ações fisicas e químicas e garantir a integral aderência do aço ao concreto variando conforme a qualidade do concreto armado.

COPALSO ESTRUTURAL: Situação anterior ao estado de ruína, podendo em certas situações ainda ser recuperado

CONDIÇÕES DE EXPOSIÇÃO: Conjunto de ações atuantes sobre o edificio ao longo do tempo.

CONSTRUÇÃO: Ação de juntar ou interligar materiais resistentes e afins, ou de dar formas a certos materiais, para se obter um suporte que sirva a atividades e necessidades da vida humana.

DEFEITO: Não conformância, imperfeição de um produto com as exigências especificas preestabelecidas. 
DEGENERESCÊNCIA: É o processo pelo qual as construções perdem as características originais de desempenho, ou seja, suas qualidades funcionais e estéticas devido ao uso e a ação dos agentes atmosféricos (condições ambientais).

DEGRADAÇÃO: Privação ou depreciação da qualidade

DESEMPENHO: Comportamento em utilização de um edificio ou de uma de suas partes. Resulta do equilibrio dinâmico entre as condições de exposição a que fica submetido e sua capacidade de reagir.

DIAGNÓSTICO: Esclarecimento completo do problema patológico a partir dos seus sintomas.

EDIFICIO: Abrigo artificial construído pelo homem para o desenvolvimento de determinadas atividades.

ELEMENTO ESTRUTURAL: Peça de concreto com fins estruturais.

ESCORA: Barra reta, com eixo disposto não verticalmente, em que os esforços solicitantes predominantes são forças normais de compressão.

ESFORÇO: Designação genérica que abrange as noções de carga (carga concentrada, carga distribuída sobre linha, carga de superficie, carga de massa), momento e tensão.

ESTADO LIMITE ÚLTIMO: Corresponde à ruína por ruptura da construção, ou parte dela, por deformação plástica excessiva ou por instabilidade.

EXAMES COMPLEMENTARES: Exames específicos, prescritos quando necessário, a partir das conclusões obtidas da vistoria e da anamnese. 
FADIGA: Diminuição da resistência de um corpo por efeito de uma solicitação cíclica.

FALHA: Incapacidade de uma construção ou de suas partes, de apresentar um desempenho mínimo preestabelecido.

FISSURA: Manifestação patológica advinda da concentração de tensões de tração em determinada região de um elemento estrutural cujas resultantes são maiores que a tensão de tração admissível do material provocando ruptura e abertura máxima de $1 \mathrm{~mm}$, ao longo desses pontos, podendo interferir de maneira estética, funcional e estrutural, e ainda, caracterizando aquelas com abertura inferior a $0,1 \mathrm{~mm}$ como microfissuras e aquelas com abertura maior que $1 \mathrm{~mm}$ como trincas.

FÔRMA: Molde onde se estabelece as características geométricas projetadas de determinado elemento estrutural dando forma, a partir de um material em estado plástico, após sua solidificação.

INSPEÇÃO: Cuidadosa e criteriosa avaliação da construção, ou de sua parte, cientificamente elaborada, utilizando-se os sentidos e experiência humana através da visualização com equipamentos específicos.

JUNTA DE DILATAÇÃO: Pequeno espaço livre deixado entre parte de uma estrutura ou componente construtivo, com fim de proporcionar uma dilatação ou encurtamento de origem térmica para evitar trincas provenientes das forças originadas.

LINTÉL: Elemento estrutural linear que realiza a ligação entre duas paredes.

MANUTENÇÃO CORRETIVA: Manutenção levada a cabo no sentido de se atingir um determinado desempenho, corrigindo uma imperfeição. 
MANUTENÇÃO PREVENTIVA: Manutenção levada a cabo em intervalos prédeterminados, ou seguindo outro critério preestabelecido, com a finalidade de diminuir a probabilidade de ocorrência de desempenho abaixo de valores mínimos preestabelecidos.

PAREDES ESTRUTURAIS: São estruturas laminares planas verticais apoiadas de modo contínuo em toda a sua base, com comprimento maior que cinco vezes a espessura.

pH: Parâmetro conhecido como "concentração hidrogeniônica" ( ou concentração de íns hidroxila) que expressa quantitativamente a acidez ou alcalinidade de uma solução. Assim, uma solução com $\mathrm{pH}<7$ é considerada ácida; $\mathrm{pH}=7$ neutra e $\mathrm{pH}>7$ considera-se a solução alcalina.

PROBLEMA PATOLÓGICO: Situação em determinado instante da vida útil da construção em que esta, ou sua parte, não apresente um desempenho satisfatório.

PROGNÓSTICO: Conjectura sobre as alternativas de desenvolvimento futuro do problema patológico

RECUPERAÇÃO/TERAPIA: Conjunto de ações que visam restituir à construção um grau de desempenho mínimo preestabelecido.

REFORÇO: Conjunto de ações destinadas a garantir que a construção, ou suas partes, resista às solicitações a que está submetida.

REFORMA: Conjunto de ações destinadas a alterar as características de uma construção (podem ter por objetivo enfrentar problemas patológicos, fazendo parte de um processo de recuperação ou restauração, ou podendo ter outros objetivos como alterações estéticas ou de utilização do espaço). 
REPARO: Ação executada numa parte da construção com o intuito de que tenha desempenho aceitável.

RESTAURAÇÃO: Conjunto de ações destinadas a restituir à construção as características elaboradas nas hipóteses de projeto.

SINTOMAS E MANIFESTAÇÕES: Formas pelas quais o problema patológico se manifesta.

TRINCA: Ruptura sob ação de pequenos esforços, segundo linhas singelas e estreitas que configuram o andamento e grau das aberturas que tal ruptura provoca na superficie de sua massa, com abertura acima de $1 \mathrm{~mm}$.

USUÁRIO: Pessoa, animal ou objeto para o qual a construção se destina

VÃO LIVRE: Distância entre faces de dois apoios contíguos de uma estrutura.

VIGAS PAREDE: São estruturas laminares planas verticais apoiados de modo descontínuo, cuja altura total, no caso de peças de tramo único livremente apoiadas, seja no mínimo igual à metade do vão, e nos demais casos seja no mínimo igual a 0,4 do vão.

VISTORIA: Inspeção detalhada, suplementada por instrumentos de medida e ensaios e ainda complementado por pesquisas, quando se fizer necessário. 